\title{
EFEITOS DO EXERCÍCIO FÍSICO NO MODELO DA DOENÇA DE PARKINSON EM RATOS
}

Tese apresentada ao Programa de Pós-Graduação em Fisiologia Humana do Instituto de Ciências Biomédicas da Universidade de São Paulo, para obtenção do Título de Doutor em Ciências. 


\section{EFEITOS DO EXERCíCIO FíSICO NO MODELO DA DOENÇA DE PARKINSON EM RATOS}

Tese apresentada ao Programa de Pós-Graduação em Fisiologia Humana do Instituto de Ciências Biomédicas da Universidade de São Paulo, para obtenção do Título de Doutor em Ciências.

Área de concentração: Fisiologia Humana

Orientador: Prof. Dr. Luiz Roberto G. Britto

Versão corrigida. A versão original eletrônica encontra-se disponível tanto na Biblioteca do ICB quanto na Biblioteca Digital de Teses e Dissertação da USP (BDTD). 
DADOS DE CATALOGAÇÃO NA PUBLICAÇÃO (CIP)

Serviço de Biblioteca e Informação Biomédica do Instituto de Ciências Biomédicas da Universidade de São Paulo

reprodução não autorizada pelo autor

Real, Caroline Cristiano.

Efeitos do exercício físico no modelo da doença de Parkinson em ratos / Caroline Cristiano Real. -- São Paulo, 2013.

Orientador: Prof. Dr. Luiz Roberto Giorgetti de Britto.

Tese (Doutorado) - Universidade de São Paulo. Instituto de Ciências Biomédicas. Departamento de Fisiologia e Biofísica. Área de concentração: Fisiologia Humana. Linha de pesquisa: Doenças neurodegenerativas e neuroproteção do exercício físico.

Versão do título para o inglês: Effects of exercise on a rat model of Parkinson's disease.

1. Fator neurotrófico derivado do encéfalo (BDNF)

2. 6-Hidroxidopamina (6-OHDA) 3. Doença de Parkinson 4. Exercício intermitente em esteira 5. Tirosina hidroxilase 6. K252a I. Britto, Prof. Dr. Luiz Roberto Giorgetti de II. Universidade de São Paulo. Instituto de Ciências Biomédicas. Programa de Pós-Graduação em Fisiologia Humana III. Título. 


\begin{abstract}
Candidato(a): $\quad$ Caroline Cristiano Real.
Título da Tese: $\quad$ Efeitos do exercício físico no modelo da doença de Parkinson em ratos.
\end{abstract}

Orientador(a): $\quad$ Prof. Dr. Luiz Roberto Giorgetti de Britto.

A Comissão Julgadora dos trabalhos de Defesa da Tese de Doutorado, em sessão pública realizada a ...................., considerou
( ) Aprovado(a)
( ) Reprovado(a)

\begin{abstract}
Examinador(a): Assinatura:
Nome:

Instituição:

Examinador(a): Assinatura:

Nome:

Instituição:

Examinador(a): Assinatura:

Nome:

Instituição:

Examinador(a): Assinatura:

Nome:

Instituição:

Presidente: Assinatura:

Nome:

Instituição:
\end{abstract}




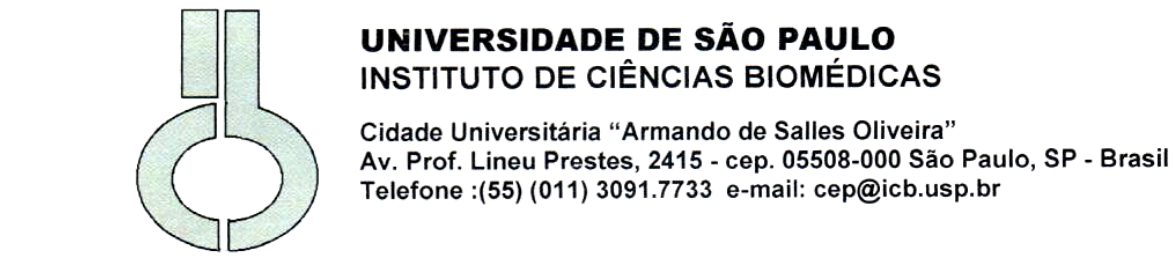

Of.CEUA.002.12

WTL/mcgn

São Paulo, 27 de janeiro de 2012.

REF.: Protocolo $n^{0} 014 / 09$.

"Efeito do exercício físico no modelo de Parkinson em ratos"

Prezado Professor,

Informo que a sua licença para uso de animais em experimentação, constante no protocolo em epígrafe, foi prorrogada até 20.02.2015.

Reitero que havendo alteração de metodologia e inserção de novos alunos ao projeto de pesquisa vinculado à referida licença a CEUA/ICB deverá ser informada.

Cordialmente,

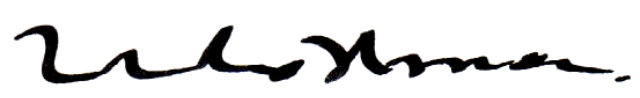

Prof. Dr. WOTHAN TAVARES DE LIMA

Coordenador - CEUA-ICB/ IUSP

IImo.Sr.

Prof Dr. LUIz Roberto GIORGettI de BRITO

Departamento de Fisiologia e Biofisica

Instituto de Ciências Biomédicas - USP 


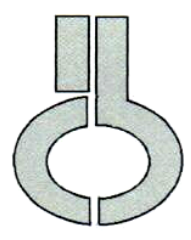

\section{UNIVERSIDADE DE SÃO PAULO INSTITUTO DE CIÊNCIAS BIOMÉDICAS}

Cidade Universitária "Armando de Salles Oliveira"

Av. Prof. Lineu Prestes, 2415 - CEP. 05508-000 São Paulo, SP - Brasil

Telefone :(55) (011) 3091.7733 - telefax : (55) (011) 3091.7438

e-mail: cep@icb.usp.br

\section{Certificado}

Certificamos que o protocolo registrado sob $\mathrm{n}^{\circ} \mathbf{1 4}$ nas fls. $\mathbf{6 7}$ do livro 02 para uso de animais em experimentação, sob a responsabilidade do $\operatorname{Prof}(a) \operatorname{Dr}(a)$ Luiz Roberto Giorgetti de Britto, Coordenador(a) da Linha de pesquisa Efeito do exercício físico no modelo de Parkinson em ratos do qual participou(aram) o(s) alunos Caroline Cristiano Real e a pesquisadora Raquel Simoni Pires, está de acordo com os Princípios Éticos de Experimentação Animal adotado pelo Colégio Brasileiro de Experimentação Animal (COBEA) e foi aprovado pela COMISSÃO DE ÉTICA EM EXPERIMENTAÇÃO ANIMAL (CEEA) em 20.02.09, com validade de 3 anos.

São Paulo, 27 de fevereiro de 2009.

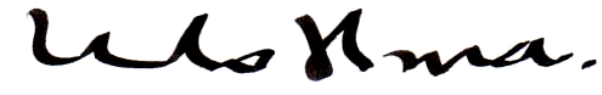

Prof.Dr.WOTHAN TAVARES DE LIMA Coordenador CEEA - ICB/USP

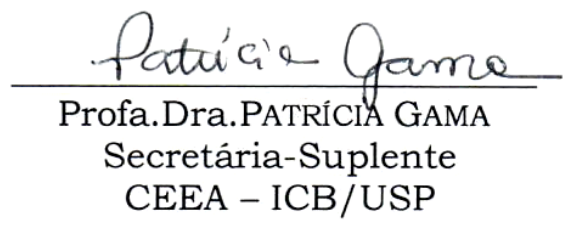


Trabalho realizado com apoio de bolsa de doutorado da FAPESP, Processo. 2008/58716-3. 
Ao meu marido, Rodrigo, por apoiar as minhas decisões e permitir que meus sonhos fornem-se realidade.

Aos meus pais, Roberto e Ivanir, pela presença constante em minha caminhada.

Dedico este trabalho! 


\section{AGRADECIMENTOS}

Assim, mais uma etapa se conclui em minha vida, e é com muita alegria que gostaria de agradecer a Deus, pois tenho certeza que estere sempre ao meu lado, e a todos que fizeram parte desta caminhada. Pessoas que com certeza sentirei muitas saudades.

Ao men orientador-amigo, Profo Britto, por acreditar em mim, pelas palarras sábias, pela minha formação acadêmica e pessoal, por permitir a realização deste trabalho, enfim por todos os momentos que passamos juntos, e que ainda virão.

À Profa Raquel, por estar presente na conclusão de mais uma etapa da minha vida, e mais que uma professora, uma colaboradora e amiga.

À minha familia, agradeço $\sigma$ incentivo, $\sigma$ carinho, a segurança, a dedicação, meus exemplos de vida, em especial ao men marido, aos mens pais è à minha tia Nanci, presentes ativamente em minha caminhada.

Ao men irmão, Willian, por ser quem é e por me socorrer com os problemas tecnológicos.

Ao meu sogro, sogra, cunhada e meu querido sobrinho que estiveram sempre ao meu lado.

À Profa Andréa, pelas valiosas sugestões ao longo do trabalho e pelas colaborações realizadas.

Às Profas Rosana Camarini e Sara Joyce, por permitirem a realização dos experimentos comportamentais.

À Profa Carolina Munhoz, pelas valiosas sugestões durante $\sigma$ exame de qualificação. 
A Profa Rosana Pagano, pelos conselhos e contribuições para a realização deste trabalho, e pela amizade.

Ao técnico do laboratório e un grande amigo, Adilson Alves, pela alegria, por todos os momentos que estivemos juntos, e claro pelo auxílio nos experimentos.

À Priscila, uma grande amiga, obrigada por todos os momentos que estivemose estaremos juntas, e pela força nesta etapa final.

Ao Mauro, à Cecília, à Kallene e à nova geração, Lívia, pela amizade, conversas, alegria, pelas ajudas em todos os momentos que precisei.

A mais nova Profa do instituto, Alice, por todo suporte e auxílio, pela sua amizade.

A todos os colegas do Laboratório de Neurobiologia celular e laboratório de Comunicação Neuronal, que de alguma forma permitiram o men crescimento e amadurecimento, Angélica, Érika, Caroline, Ana, Marina, André, Danilo, Jáfia, Katherine, Juliana, Samira, Taisa, Hadassa e Priscila. Em especial à Gabi, pelos momentos que estivemos juntas na padronização deste modelo, e por todas as colaborações científicas.

A todos os colegas e amigos do ICB, em especial à Ana Maria, Aline, Rafaela, Cleyton e Hilde pelo carinho e amizade.

Aos funcionários do departamento de fisiologia e biofísica, pela disponibilidade, em especial aos funcionários do biotério, Vilson, Maria, Marcelo, Renaide e Cleonice. Pessoas queridas, a quem pude contar com a ajuda sempre.

Aos animais, os quais propiciaram o desenvolvimento desta pesquisa. À FAPESP e CNPQ, pelo auxílio financeiro. 


\section{RESUMO}

Real CC. Efeitos do exercício físico no modelo de Parkinson em ratos. [tese (Doutorado em Fisiologia Humana)]. São Paulo: Instituto de Ciências Biomédicas, Universidade de São Paulo; 2013.

As doenças neurodegenerativas representam um dos grandes desafios da neurociência atual. A Doença de Parkinson (DP), por exemplo, acomete milhões de indivíduos no mundo todo, sendo que o número de doentes deve duplicar ao longo dos próximos 20 anos. Assim, é natural que a DP seja alvo de intensas pesquisas no sentido de desenvolver possíveis estratégias de tratamento e prevenção. Diversos estudos demonstram os efeitos benéficos proporcionados pelo exercício físico sobre o sistema nervoso central. Porém, poucos estudos correlacionam os efeitos do exercício físico com a DP. Assim, o objetivo principal deste projeto foi investigar as alterações histológicas e comportamentais decorrentes da prática de diferentes protocolos de exercício físico no modelo da DP induzida por 6-OHDA (6hidroxidopamina) em ratos, e o papel do BDNF nos mecanismos envolvidos com as alterações encontradas. Nosso estudo foi dividido em duas etapas, sendo elas, efeito neuroprotetor do exercício, onde os animais treinavam antes e depois (EXA+EXD), ou apenas depois (EXD) da indução da DP; e o efeito preventivo do exercício, onde os animais praticaram exercício apenas antes (EX) da indução da DP, sendo os grupos controles animais sedentários. Para analisar o efeito do BDNF, os animais foram divididos em dois grandes grupos, sendo eles (1) aqueles que receberam a injeção intraestriatal de K252a (inibidor de TrkB) com o objetivo de bloquear as ações do BDNF; (2) aqueles que não receberam o bloqueador do receptor de BDNF. O protocolo de exercício consistiu de treino em esteira (3x/semana, 40 minutos por 4 semanas). Após o protocolo específico para cada grupo, realizaram-se os testes comportamentais (campo aberto e teste de rotação), e posteriormente a análise neuroquímica das regiões encefálicas de interesse, sendo elas, substância negra pars compacta (SNc) e estriado (CPu). Utilizaram-se as técnicas de imuno-histoquímica, immunoblotting, fluorescência da dihidroetina (DHE) e dosagem de BDNF por ELISA. Os resultados obtidos revelaram, de modo geral, que os diferentes protocolos de exercício intermitente foram eficazes na melhora do sistema dopaminérgico e capazes de recuperar o comportamento dos ratos injetados com 6-OHDA. Demonstramos ainda, que o beneficio promovido pelo exercício intermitente parece ter o envolvimento do sistema BDNF-TrkB, sugerindo ser esse um importante sistema de prevenção e neuroproteção na DP.

Palavras-chave: BDNF. 6-OHDA. Doença de Parkinson. Exercício intermitente em esteira. K252a. Tirosina Hidroxilase. 


\begin{abstract}
Real CC. Effects of exercise on a rat model of Parkinson's disease. [Ph. D. thesis (Human Physiology)]. São Paulo: Instituto de Ciências Biomédicas, Universidade de São Paulo; 2013.

Neurodegenerative diseases represent one of the major challenges of current neuroscience. Parkinson's Disease (PD), for example, affects millions of individuals worldwide, and the number of patients is expected to double over the next 20 years. It is therefore natural that the DP is the subject of intense research to develop possible strategies for treatment and prevention. Several studies have shown the beneficial effects by physical exercise on the central nervous system. However, few studies have correlated the effects of exercise on PD. The aim of this study was to investigate the effects of different protocols of intermittent treadmill exercise-induced behavioral and histological/neurochemical changes in a rat model of unilateral PD induced by striatal injection of 6-hydroxydopamine (6-OHDA), and the role of BDNF in the exercise effects. Our study was divided into two stages: (1) neuroprotective effects of exercise, where the animals trained before and after (EXA + EXD) or only after (EXD) the PD induction; and (2) preventive effects of exercise, where the animals exercised only before PD induction (EX). Sedentary rats were used as control groups. To analyze the effects of BDNF, the animals were divided into two major groups, namely (1) those who received intrastriatal injection of K252a (inhibitor of TrkB) with the aim of blocking the actions of BDNF, (2) those who did not receive the BDNF receptor blocker. The exercise protocol consisted of treadmill training (3x/week, 40 minutes for 4 weeks). One month after 6-OHDA injections, the animals were subjected to behavioral tests (open field and rotation induced by apomorphine), and the brains were collected for immunohistochemistry, immunoblotting, fluorescence of dihidroetina (DHE), and ELISA assays, in which we analyze changes in the substantia nigra pars compacta $(\mathrm{SNc})$ and the striatum (caudate-putamen, $\mathrm{CPu}$ ). The results showed, in general, that the different intermittent exercise protocols were effective in improving of dopaminergic system and able to recover the behavior of the animals injected with 6-OHDA. We also demonstrated that the benefit promoted by intermittent exercise appears to have the involvement of the BDNFTrkB, suggesting this an important prevention and neuroprotection system in PD.
\end{abstract}

Keywords: Brain derived neurotrophic factor (BDNF). 6-OHDA. Parkinson's disease. Intermittent treadmill exercise. Tyrosine hydroxylase. K252a. 


\section{LISTA DE ILUSTRAÇÕES}

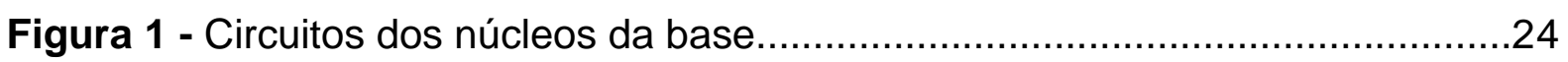

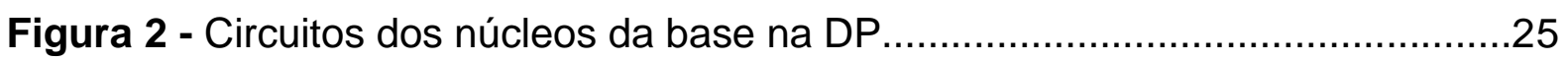

Figura 3 - Imagens digitais ilustrando 0 animal fixado ao aparelho estereotáxico. . .45

Figura 4 - Imagem digital da esteira ergométrica adaptada para ratos. .48

Figura 5 - Imagens digitais ilustrando o teste de ratos em campo aberto

Figura 6 - Imagem do rato fixado ao rota count........

Figura 7 - Esquema llustrativo da SNc do encéfalo de ratos .52

Figura 8 - Esquema llustrativo do CPu do encéfalo de ratos .53

Figura 9 - Imagem digital de corte coronal de encéfalo de rato ilustrando a dupla marcação para Fluoro-Gold e TH na SNc. .59

Figura 10 - Imagens digitais de cortes coronais da SNc de rato ilustrando a expressão de TH na SNc após diferentes doses de injeção intraestriatal unilateral de 6-OHDA. 60

Figura 11 - Imagens digitais de cortes coronais de encéfalo de rato ilustrando a histoquímica para Fluoro-Jade B no CPu e SNc após a indução da DP por injeção intraestriatal unilateral de 6-OHDA.

Figura 12 - Imagens digitais de cortes coronais da SNc de rato ilustrando a imunohistoquímica para OX42 na SNc após a indução da DP por injeção intraestriatal unilateral de 6-OHDA. 62

Figura 13 - Imagem digital de corte coronal de encéfalo de rato ilustrando a presença de microesferas no CPu e na SNc. .62

Figura 14 - Desenho experimental. .64 
Figura 15 - Análise da frequência de locomoção de ratos expostos por 5 minutos no campo aberto

Figura 16 - Análise da frequência de locomoção de ratos expostos por 5 minutos no campo aberto

Figura 17 - Efeitos do treino em esteira e do bloqueio do receptor de BDNF sobre o comportamento rotacional induzido por apomorfina em ratos .68

Figura 18 - Efeitos do exercício em esteira e do bloqueio do receptor de BDNF sobre os níveis de BDNF na SNc.

Figura 19 - Efeitos do exercício em esteira e do bloqueio do receptor de BDNF sobre os níveis de BDNF no CPu.

Figura 20- Efeitos do exercício em esteira e do bloqueio do receptor de BDNF sobre a expressão de TH na SNc. .73

Figura 21 - Efeitos do exercício em esteira e do bloqueio do receptor de BDNF sobre a análise semi-quantitativa da porcentagem de células TH-positivas na SNc.

Figura 22 - Efeitos do exercício em esteira e do bloqueio do receptor de BDNF sobre os níveis de TH na SNc....

Figura 23 - Efeitos do exercício em esteira e do bloqueio do receptor de BDNF sobre a expressão de $\mathrm{TH}$ no $\mathrm{CPu}$.

Figura 24 - Efeitos do exercício em esteira e do bloqueio do receptor de BDNF sobre a expressão de $\mathrm{TH}$ em terminações dopaminérgicas no $\mathrm{CPu}$

Figura 25 - Efeitos do exercício em esteira e do bloqueio do receptor de BDNF sobre os níveis de TH no CPu

Figura 26 - Desenho experimental.

Figura 27 - Efeitos do treino em esteira antes da indução da DP e do bloqueio do receptor de BDNF sobre o comportamento rotacional induzido por apomorfina em ratos, no $29^{\circ}$ dia após a indução do modelo da DP 
Figura 28 - Efeitos do treino em esteira antes da indução da DP sobre a expressão de BDNF na SNc e no $\mathrm{CPu}$, no $7^{\circ}$ dia após a indução do modelo da DP.

Figura 29 - Efeitos do treino em esteira antes da indução da DP sobre a fluorescência da DHE na SNc, no 7º dia após a indução do modelo da DP.....

Figura 30 - Efeitos do treino em esteira antes da indução da DP sobre a fluorescência da DHE no CPu, no $7^{\circ}$ dia após a indução do modelo da DP.

Figura 31 - Efeitos do treino em esteira antes da indução da DP sobre a expressão de DHE na SNc e no CPu, no 7º dia após a indução do modelo da DP. .98

Figura 32 - Efeitos do treino em esteira antes da indução da DP sobre a expressão de iNOS na SNc e no CPu, no 7º dia após a indução do modelo da DP. .99

Figura 33 - Efeitos do treino em esteira antes da indução da DP sobre a expressão de OX42 na SNc, no 7º dia após a indução do modelo da DP. 101

Figura 34 - Efeitos do exercício em esteira sobre a expressão de OX42 no CPu, no $7^{0}$ dia após a indução do modelo da DP. .102

Figura 35 - Efeitos do treino em esteira antes da indução da DP sobre a expressão de OX42 na SNc e no CPu, no 7º dia após a indução do modelo da DP. 103

Figura 36 - Efeitos do treino em esteira antes da indução da DP sobre a expressão de GFAP na SNc, no 7º dia após a indução do modelo da DP. 105

Figura 37 - Efeitos do treino em esteira antes da indução da DP sobre a expressão de GFAP na SNc, no 7º dia após a indução do modelo da DP. 106

Figura 38 - Efeitos do treino em esteira antes da indução da DP sobre a expressão de GFAP no CPu, no $7^{\circ}$ dia após a indução do modelo da DP.....

Figura 39 - Efeitos do treino em esteira antes da indução da DP sobre a expressão de GFAP no CPu, no $7^{0}$ dia após a indução do modelo da DP..... 108

Figura 40- Efeitos do treino em esteira antes da indução da DP sobre a expressão de TH na SNc, no $7^{\circ}$ dia após a indução do modelo da DP. 
Figura 41 - Efeitos do treino em esteira antes da indução da DP sobre a expressão de TH na SNc, no $7^{\circ}$ dia após a indução do modelo da DP.

Figura 42 - Efeitos do treino em esteira antes da indução da DP e do bloqueio de receptor de BDNF sobre a expressão de TH na SNc, no $30^{\circ}$ dia após a indução do modelo da DP.

Figura 43 - Efeitos do treino em esteira antes da indução da DP e do bloqueio de receptor de BDNF sobre a expressão de TH na SNc, no $30^{\circ}$ dia após a indução do modelo da DP.

Figura 44 - Efeitos do treino em esteira antes da indução da DP sobre a expressão de TH no $\mathrm{CPu}$, no $7^{\circ}$ dia após a indução do modelo da DP 116

Figura 45 - Efeitos do treino em esteira antes da indução da DP sobre a expressão de TH no CPu, no $7^{\circ}$ dia após a indução do modelo da DP 117

Figura 46 - Efeitos do treino em esteira antes da indução da DP e do bloqueio de receptor de BDNF sobre a expressão de $\mathrm{TH}$ no $\mathrm{CPu}$, no $30^{\circ}$ dia após a indução do modelo da DP.

Figura 47 - Efeitos do treino em esteira antes da indução da DP e do bloqueio de receptor de BDNF sobre a expressão de $\mathrm{TH}$ no $\mathrm{CPu}$, no $30^{\circ}$ dia após a indução do modelo da DP..... 


\section{LISTA DE SIGLAS E ABREVIATURAS}

6-OHDA - 6-hidroxidopamina

BDNF - fator neurotrófico derivado do encéfalo

CA - campo aberto

CLT - animais sedentários injetados com salina

CPu - caudado e putâmen

DA - dopamina

DHE - dihidroetidina

DP - doença de Parkinson

EROs - espécies reativas de oxigênio

EX - animais treinados 4 semanas antes da injeção de salina

EX+DP - animais treinados 4 semanas antes da injeção de 6-OHDA

EXA+EXD - animais exercitados por 4 semanas antes e 4 semanas depois da injeção de 6-OHDA

EXD - animais exercitados por 4 semanas depois da injeção de 6-OHDA

GFAP - proteína acídica fibrilar glial

iNOS - óxido nítrico sintase induzível

K252a - inibidor do receptor de BDNF, TrkB

LPS - lipopolissacarídeo

OX42 - marcador de microglia

SED - animais sedentários injetados com 6-OHDA (capítulo 4)

SED - animais sedentários injetados com salina (capítulo 5)

SED+DP - animais sedentários injetados com 6-OHDA

SNc - substância negra pars compacta

$\mathrm{TH}$ - tirosina hidroxilase 
CAPÍTULO 1 - INTRODUÇÃO

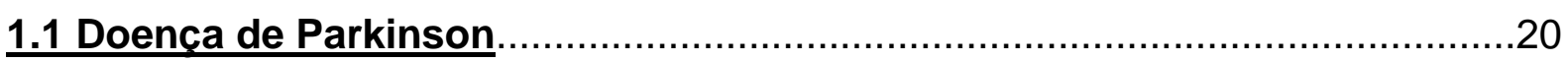

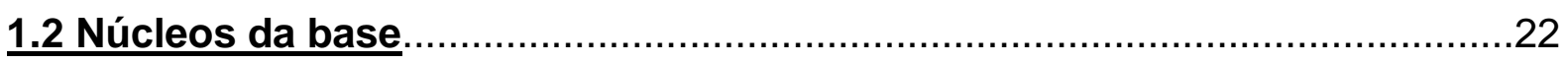



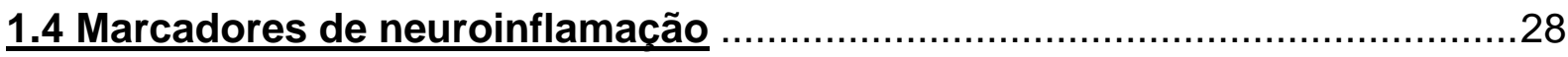







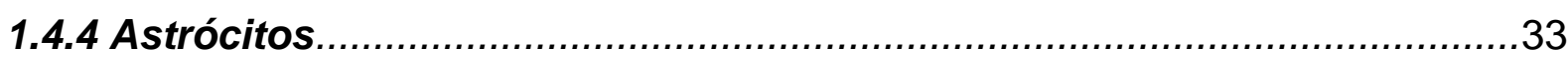

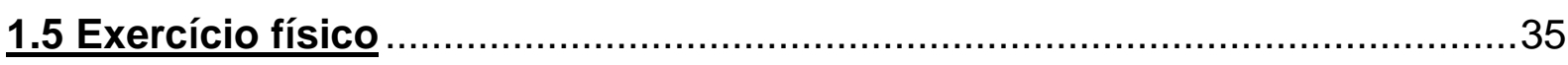

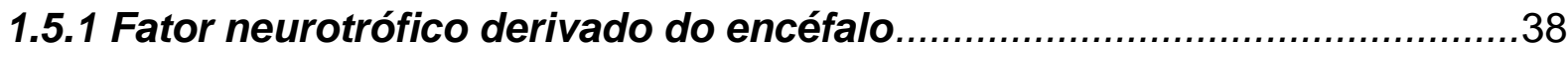

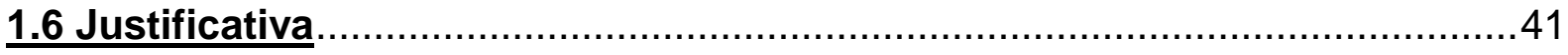

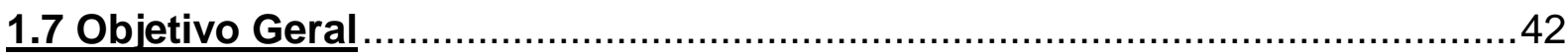

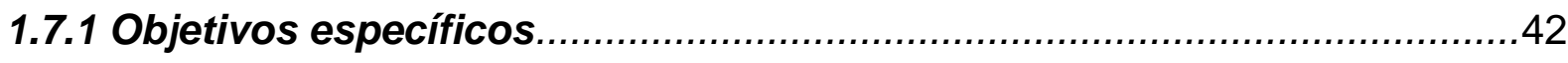

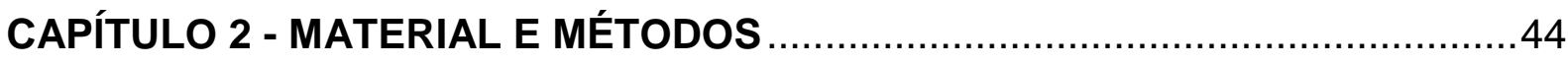



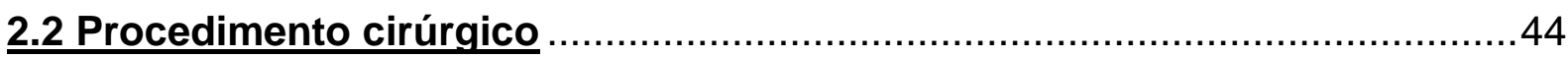



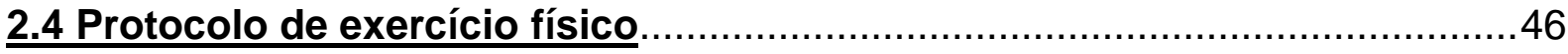

2.5 Qualificação e quantificação da lesão parkinsoniana .................................48









2.5.3 Marcação retrógrada de neurônios da substância negra ..........................53

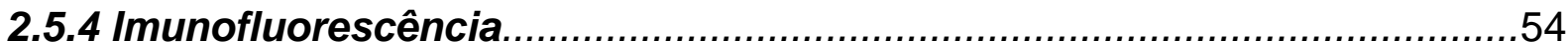

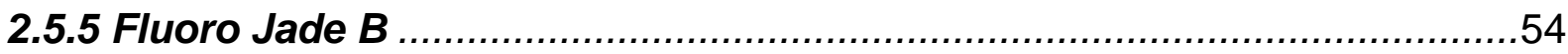

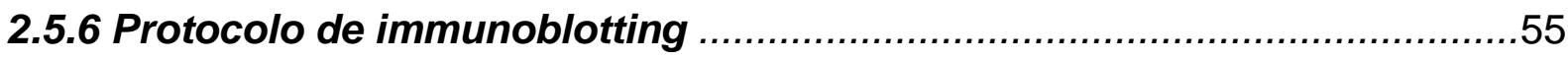

2.5.7 Análise da Fluorescência Derivada dos produtos de oxidação da dihidroetidina (DHE) em cortes histológicos...............................................56



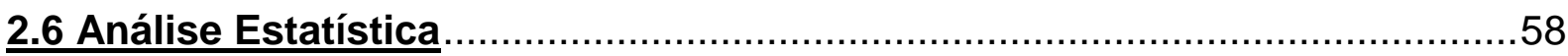


CAPÍTULO 3 - CARACTERIZAÇÃO DO MODELO DA DOENÇA DE PARKINSON

CAPÍTULO 4 - O PAPEL DO BDNF NOS EFEITOS PROMOVIDOS PELO EXERCÍCIO .63



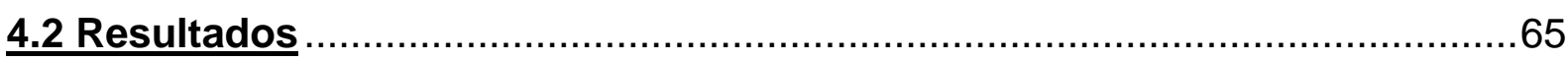

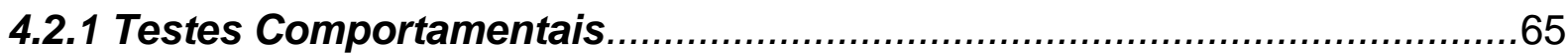

4.2.1.1 Campo aberto

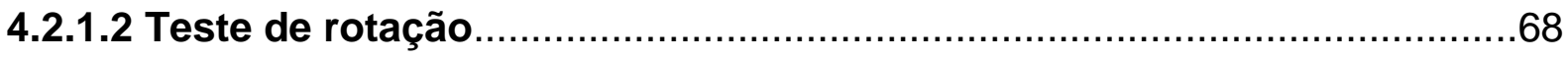

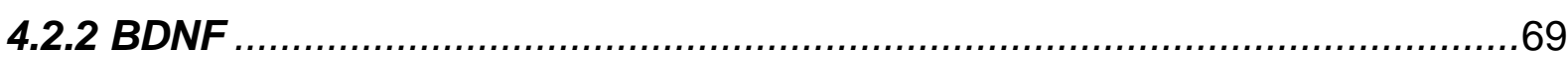

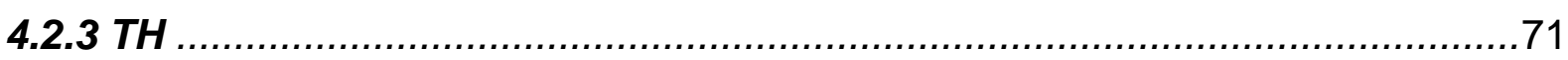

4.2.3.1 Substância negra pars compacta....................................................

4.2.3.2 Estriado

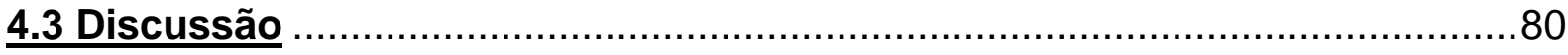

4.3.1 Envolvimento do BDNF nas alterações neuroquímicas e comportamentais

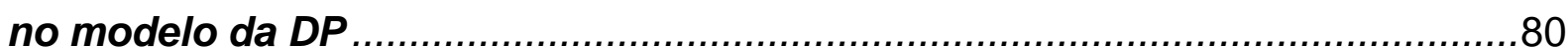





CAPÍTULO 5 - POSSÍVEL EFEITO PREVENTIVO DO EXERCíCIO FÍSICO NA NEUROTOXICIDADE INDUZIDA PELA INJEÇÃO DE 6-OHDA EM RATOS

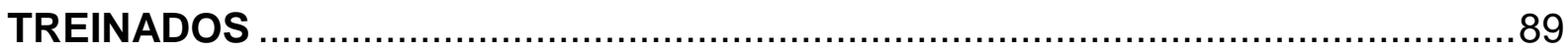

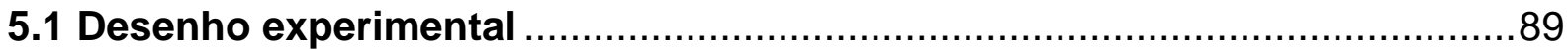

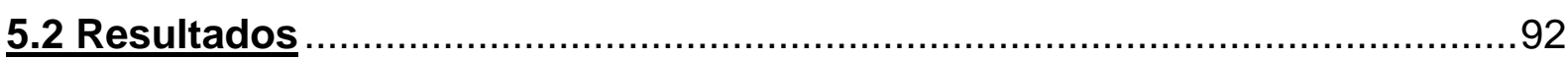

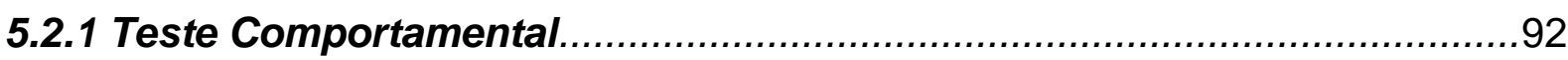



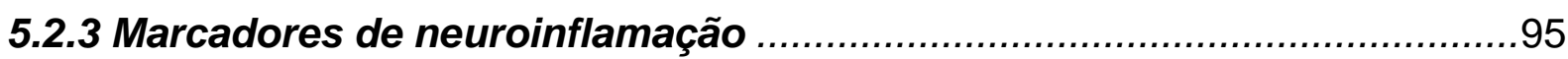

5.2.3.1 Participação das espécies reativas derivadas de oxigênio (DHE)..........95

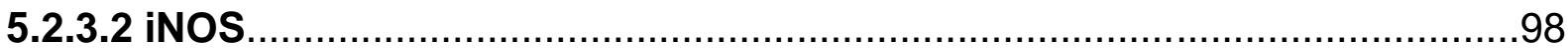

5.2.3.3 OX42

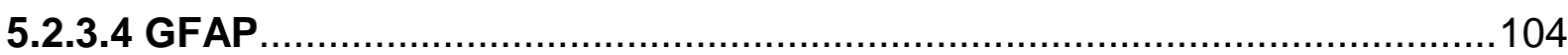



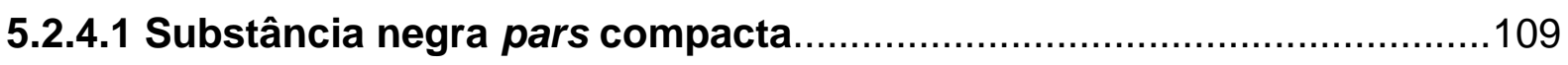

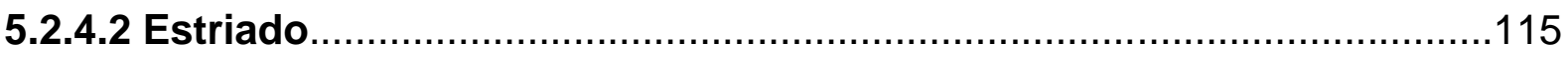




5.4 Conclusões

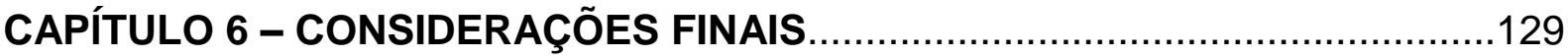



APÊNDICES

APÊNDICE A - Paper publicado no periódico Neuroscience com os dados do

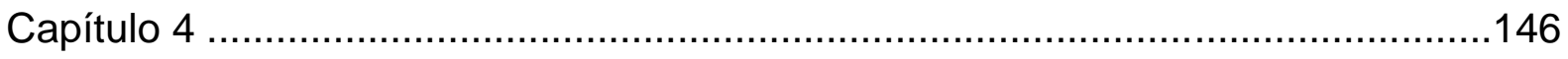

APÊNDICE B - Tabelas com os dados do capítulo 4..........................................159

APÊNDICE C - Tabelas com os dados do capítulo 5...........................................162 


\section{CAPÍTULO 1 - INTRODUÇÃO}

\subsection{Doença de Parkinson}

A Doença de Parkinson acomete milhões de indivíduos no mundo todo, sendo que o número de doentes deve duplicar ao longo dos próximos 20 anos. A ocorrência da doença na maioria dos casos é de origem idiopática, e apenas $5 \%$ dos casos têm natureza hereditária. Esta se manifesta numa média etária de 55 anos, afetando cerca de $1 \%$ da população com mais de 50 anos. $O$ índice aumenta com o avanço da idade, atingindo $2 \%$ da população após os 65 anos (Hughes et al., 1993). É muito baixa a frequência em indivíduos com menos de 40 anos (Golbe, 1991).

As primeiras descrições dos distúrbios motores presentes na doença de Parkinson (DP) foram feitas por James Parkinson, em 1817, em seu trabalho "An essay on the shaking palsy" (Blum et al., 2001; Parkinson, 1817). Cem anos depois, determinou-se que a doença estava relacionada à perda de neurônios na substância negra em sua porção compacta ( $\mathrm{SNc}$ ), e consequentemente da concentração de dopamina (DA) na área de projeção destes neurônios, ou seja, no estriado. A morte neuronal de origem idiopática na SNc chega a 5\% ao ano. Estes neurônios são impregnados por neuromelanina, atribuindo-Ihes uma coloração escura; porém, com a morte destes, ocorre uma despigmentação da SNc, deixando a estrutura clara. Associado à perda neuronal, há a formação de precipitados protéicos intracitoplasmáticos constituídos principalmente pelas proteínas sinucleína, parkina e ubiquitina, que são chamados de corpúsculos de Lewy (Tretiakoff, 1919).

A SNc e o estriado são estruturas que compõem os núcleos da base, descritos detalhadamente no próximo item (Kandel et al., 2012; Mink, 1999). Esses núcleos estão evolvidos na maioria dos programas motores de rotina, além de participarem do aprendizado e da formação de memórias, participando dos movimentos voluntários (Calne, 1994; Kandel et al., 2012; Fearnley, Lees, 1991).

Assim, a DP é definida como uma doença neurodegenerativa crônica progressiva que promove distúrbios motores extrapiramidais, tais como bradicinesia (lentidão dos movimentos voluntários ou dificuldades em iniciar os movimentos) ou acinesia (falta de movimentos), tremores de repouso, rigidez muscular, alterações da marcha e instabilidade postural com quedas frequentes e falta de expressão facial 
(Agid, 1991; Kandel et al., 2012; Smith, Zigmond, 2003). Os sintomas da doença só aparecem após redução de $40-60 \%$ dos neurônios nigrais e dos níveis dopaminérgicos no estriado (Obeso et al., 2000).

Além dos sintomas motores, outro fator envolvido na DP que foi negligenciado por muitos anos é a presença de alterações cognitivas (Kandel et al., 2012). Os sintomas cognitivos acometem cerca de $60 \%$ das pessoas com DP (revisado por Chaudhuri et al., 2006). As alterações podem ser lentidão dos pensamentos, demora em responder perguntas, desconexão com o ambiente (ausência), falta de iniciativa, alucinações, pânico e demência, além de quadro depressivo em cerca de $40 \%$ dos pacientes (revisado por Chaudhuri et al., 2006; Cummings, 1992). A demência associada à DP é muito comum, com prevalência estimada por alguns estudos variando entre $20 \%$ e $40 \%$ (Cummings, 1988) e prevalência acumulada podendo chegar a $80 \%$, de acordo com os resultados do estudo de Aarsland et al. (2003). Vale ressalvar que a média da idade da população examinada neste estudo foi superior a 70 anos, o que pode ter contribuído para prevalência tão alta. Barbosa et al. (1987) demonstraram prevalência de demência associada à DP de 18,7\% em estudo realizado no Brasil. As alterações cognitivas podem comprometer consideravelmente a qualidade de vida do doente e até mesmo de seus cuidadores. Em fases iniciais é necessária a aplicação de testes específicos para detecção do declínio mental. $O$ termo demência associada à DP refere-se à demência que se desenvolve pelo menos 12 meses após a instalação das alterações motoras. Quando a demência desenvolve-se nos primeiros 12 meses de evolução da doença, preenche-se o critério para o diagnóstico de demência de corpos de Lewy (McKeith et al., 2005). 


\subsection{Núcleos da base}

Os núcleos da base formam um circuito extremamente organizado, onde diferentes regiões podem ser ativadas para funções e circunstâncias específicas. Esses núcleos participam do controle do movimento, pertencendo ao sistema motor extrapiramidal, assim como da aprendizagem associativa, planejamento, memória de trabalho ou de curto prazo e respostas emocionais, sendo o circuito motor o mais compreendido (Kandel et al., 2012; revisado por Obeso et al., 2008). Este sistema tem um papel crítico no planejamento, aprendizado e execução de novas habilidades motoras e movimentos automáticos (Doyon et al., 2009).

O circuito é composto essencialmente por quatro núcleos, sendo eles, estriado (núcleo accumbens, caudado e putâmen (CPu), globo pálido (interno (GPi) e externo (GPe)), substância negra (pars compacta (SNc) e pars reticulada (SNr)) e núcleo subtalâmico (NST). Eles não se comunicam diretamente com a medula espinal, mas recebem projeções do córtex, tálamo e regiões do tronco encefálico, realizam as correções necessárias do movimento e enviam sinais de volta ao córtex através do tálamo ou núcleo pedúnculo-pontino (Kandel et al., 2012).

No modelo descrito por Alexander e Crutcher (1990), o estriado é considerado o principal núcleo do circuito por ser o responsável por receber aferências glutamatérgicas (Calabresi et al., 1998; Kita, 1996) topograficamente organizadas de todas as regiões corticais, (através do circuito corticoestriatal) (Goldman, Nauta, 1977), aferências excitatórias dos núcleos intratalâmicos, projeções dopaminérgicas da SNc e aferências serotonérgicas dos núcleos da rafe. O estriado é o componente com maior diversidade de neurotransmissores nos núcleos da base, com cerca de 40 tipos (Graybiel, Ragsdale, 1983), e assim representa um complexo circuito neuroquímico. Com a chegada de aferências glutamatérgicas ocorrem sinapses excitatórias com neurônios GABAérgicos espinhosos médios, responsáveis por originar as duas vias eferentes do estriado, sendo uma direta (GABA/substância $P$ ) e outra indireta (GABA/encefalina). As eferências do estriado permitem a esse núcleo comunicar-se com o GPi e SNr, através das quais toda a informação processada nos núcleos da base é enviada à medula, através do núcleo pedúnculo-pontino ou ao tálamo e deste de volta à região cortical de origem (Noback et al., 1999). 
Porém, a ativação da via direta ou indireta pelo estriado é definida pelas projeções dopaminérgicas provenientes da SNc. Os neurônios espinhosos médios estriatais que se projetam para os núcleos de saída expressam os dois tipos de receptor dopaminérgicos, D1 e D2, em populações diversas, e a ativação de cada um deles pelo sistema dopaminérgico que irá determinar qual a via a ser ativada. Assim, o sistema dopaminérgico, ao estimular receptores diferentes, é capaz de modular e filtrar as entradas glutamatérgicas no estriado (revisado por Obeso et al., 2008). Quando a dopamina atua nos neurônios que expressam o receptor D1 ocorre ativação da via direta, e ao atuar nos que expressam o receptor D2 a ativação é da via indireta. Com a ativação da via direta ocorre inibição dos neurônios gabaérgicos do GPi e SNr, e assim ocorre desinibição talâmica, ou seja, ativação da alça tálamocortical responsável em facilitar o movimento. Já a ativação da via indireta promove inibição do GPe, e consequentemente desinibição do NST, pois este é inibido por neurônios gabaérgicos do GPe. O NST, por sua vez, possui neurônios glutamatérgicos responsáveis por ativar a atividade inibitória do GPi, promovendo assim inibição dos neurônios dos núcleos-alvos, ou seja, inibição da alça tálamocortical responsável em inibir o movimento (Kandel et al., 2012; Obeso et al., 2008). Logo, notamos que o controle da atividade dos núcleos da base está diretamente relacionado à expressão diferencial dos receptores D1 e D2 responsáveis em ativar as diferentes vias, e assim, promover respostas distintas nos núcleos talâmicos ventrolateral e centro-mediano (Blandini et al., 2000; Obeso et al., 2000). A presença de níveis aumentados de DA no estriado tende a ativar neurônios que expressam D1 na via direta, enquanto inibe os neurônios da via indireta que expressam D2 (Kandel et al., 2012) Desta maneira, fica evidente a importância do sistema dopaminérgico no funcionamento adequado dos núcleos da base (Figura 1).

Os corpos celulares de neurônios do sistema dopaminérgico estão agrupados em três regiões específicas, sendo elas, SNc (A9), em maior quantidade, na área tegumentar ventral (VTA - A10) e área retrorubral (A8). Os neurônios da SNc são responsáveis, principalmente, pela modulação da excitabilidade dos núcleos da base através das projeções nigroestriatais e os neurônios da VTA estão mais relacionados a mecanismos de recompensa, processos cognitivos e comportamentos motivados através de circuitos límbicos e projeções para o estriado, sendo responsáveis por comportamentos motivados (Lima, 2010; revisado por 
Obeso et al., 2008). A área retrorubral foi descrita pela primeira vez por Dahlstrom e Fuxe (1964) como dopaminérgica, porém suas funções e as separações entre as áreas $A 8, A 9$ e $A 10$ não são muito claras.

Os neurônios da via nigroestriatal apresentam, normalmente, baixa frequência de atividade, responsável pela liberação contínua de DA no estriado. Por outro lado, em situações de antecipação do movimento nota-se um aumento sincronizado da frequência da atividade neuronal. Assim, a fase em que o sistema dopaminérgico se encontra irá determinar a ativação de receptores D1 (via direta) ou D2 (via indireta) (revisado por Obeso et al., 2008).

Figura 1 - Circuitos dos núcleos da base.

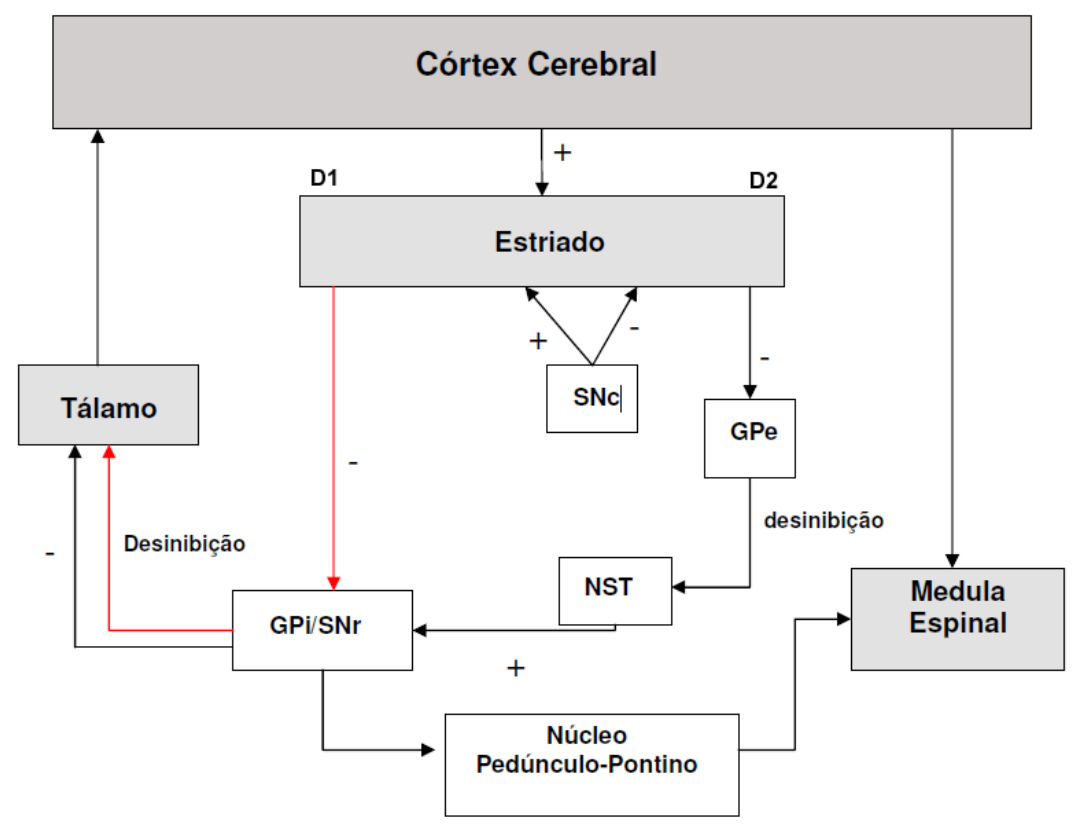

As setas vermelhas representam a via direta do estriado e as pretas a via indireta. Note que a via direta promove desinibição do tálamo, enquanto a indireta promove inibição. Abreviaturas no texto.

Fonte: Modificado de Alexander e Crutcher (1990).

Por outro lado, a morte dos neurônios dopaminérgicos da SNc promove o déficit de DA no sistema e assim redução da ativação da via direta e hiperatividade da via indireta, resultando em redução do movimento. Com a maior ativação da via indireta ocorre aumento na atividade neuronal do GPi e SNr, levando a uma inibição excessiva dos sistemas motores tálamo-corticais. A inibição excessiva do tálamo ocorre devido à reduzida ativação dos receptores dopaminérgicos, devido à deficiência de DA; logo, ocorre diminuição da inibição dos neurônios da via indireta, 
e assim aumento da inibição do GPe, resultando em desinibição do NST, e diminuição da atividade da via direta. Assim, com a excitação pelo NST e diminuição da inibição pela via direta, a atividade de saída dos núcleos da base (GPi e SNr) aumenta, gerando então excessiva inibição dos sistemas motores, sendo diminuída a resposta cortical para a medula espinal (revisado por Obeso et al., 2008; Alexander, Crutcher, 1990) (Figura 2). Esta hiperativação dos núcleos GPi e NST pode ser confirmada em estudos experimentais com macacos submetidos ao modelo da DP por MPTP. Após a indução da DP os pesquisadores realizaram a lesão destes núcleos, o que promoveu uma diminuição dos sintomas motores apresentados por estes animais. Após anos de pesquisas, este método passou a ser utilizado na clínica médica para melhora dos sintomas motores de pacientes em estágios avançados da DP (revisado por Obeso et al., 2008).

Figura 2 - Circuitos dos núcleos da base na DP.

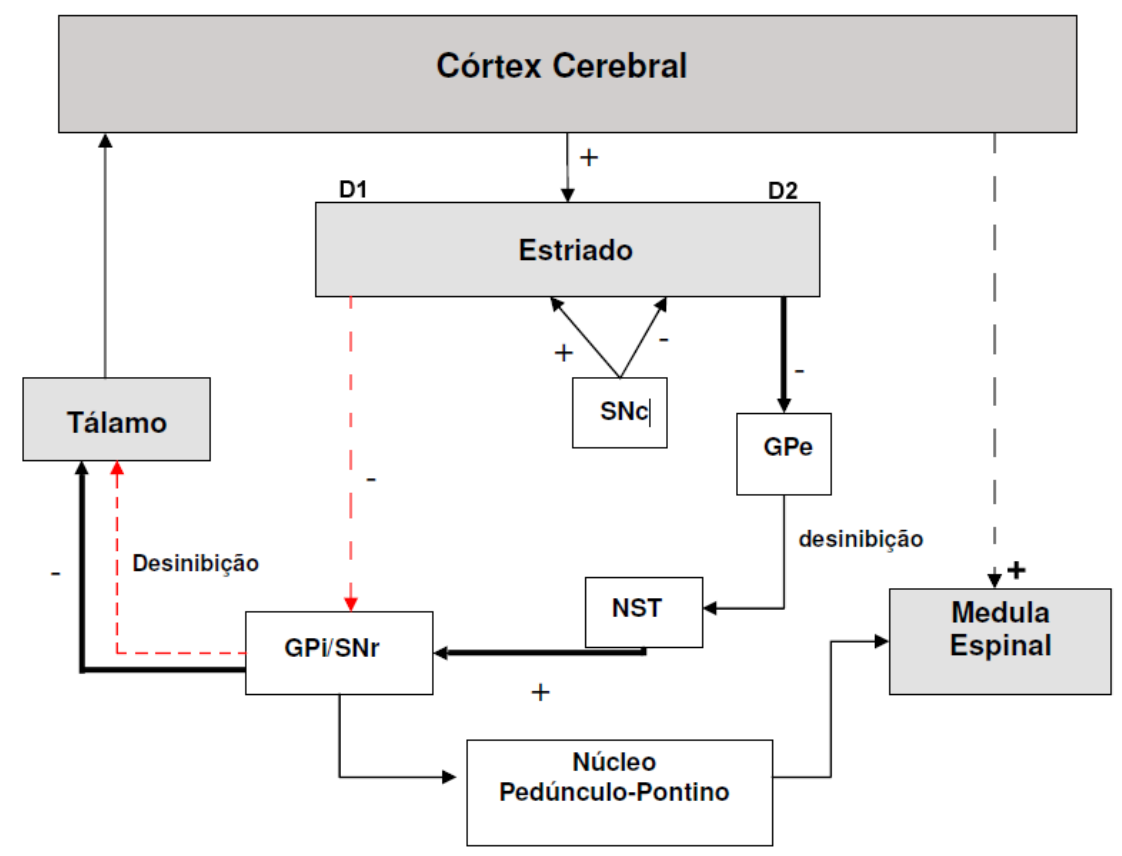

As setas vermelhas representam a via direta do estriado e as pretas a via indireta. Note que as linhas tracejadas representam os circuitos que estão comprometidos na DP e as linhas mais grossas os circuitos que se encontram com a atividade exarcebada. Note que 0 resultado final será uma inibição excessiva do tálamo e assim há prejuízo do movimento motor. Abreviaturas no texto.

Fonte: Modificado de Alexander e Crutcher (1990). 


\subsection{Agentes Neurotóxicos}

Algumas substâncias são empregadas em estudos animais por possuírem diversas propriedades, capazes de produzir a mesma lesão seletiva de neurônios dopaminérgicos da SNc, acompanhada de sintomas semelhantes ao parkinsonismo, permitindo assim o desenvolvimento de modelos animais desta doença. Entre estas substâncias estão: 1) as análogas da DA como a 6-hidroxidopamina (6-OHDA), que está presente no encéfalo de pacientes com DP (Jellinger et al., 1995); 2) contaminantes da heroína sintética - 1-metil-4-fenil-1,2,3,6-tetrahidropiridina (MPTP); 3) herbicidas e pesticidas como a rotenona, paraquat e maneb; 4) metais como manganês; 5) Lipopolissacarídeo (LPS). Todos os modelos animais demonstram ativação de microglia na SN após a injeção local e um paralelismo entre a progressão da lesão e a ativação da microglia (Purisai et al., 2007; Smeyne et al., 2005).

A 6-OHDA foi o primeiro agente neurotóxico utilizado no modelo de Parkinson, sendo uma droga seletiva para células catecolaminérgicas (Ungerstedt, 1968), produzindo um modelo que gera ampla resposta inflamatória (Blandini et al., 2008). Originalmente, a 6-OHDA foi isolada por Senoh e Witkop (1959a,b), e seus efeitos biológicos foram demonstrados pela primeira vez em 1963, por Porter e colaboradores (1963). Seus estudos demonstraram que a 6-OHDA era muito eficiente na diminuição de noradrenalina em nervos simpáticos (Porter et al., 1963, 1965). Em experimentos com cultura de células, é comum associá-la à droga inibidora de alta afinidade da recaptação de noradrenalina, a desipramina, para tornar o efeito seletivo às células dopaminérgicas (Deumens et al., 2002), porém esta associação não é capaz de prevenir citotoxicidade (revisado por Blum et al., 2001). Por outro lado, estudos in vivo em que se injeta a droga diretamente no estriado não utilizam inibidores (Henning et al., 2008; Lee et al., 1996), possivelmente pelo fato de alguns estudos demonstrarem morte de neurônios noradrenérgicos no locus ceruleus postmortem de humanos (Zarow et al., 2003), podendo este ser o fator responsável pela discinesia encontrada nestes pacientes (Srinivasan, Schmidt, 2004).

A injeção de 6-OHDA na porção centro-lateral do caudado-putâmen (CPu) é o modelo que mais se aproxima do quadro encontrado em humanos (Tillerson et al., 
2002), principalmente se a lesão for bilateral (Deumens et al., 2002); porém, é costumeiro fazer-se a lesão unilateral do sistema nigro-estriatal, de forma a aproveitar o lado não lesado do mesmo animal como controle dos efeitos da lesão, o que é muito utilizado em modelos com ratos (Blandini et al., 2007; Grigor'ian, Bazian, 2007; Schwarting, Huston, 1996). A perda dos neurônios ocorre logo após a injeção, principalmente em injeções na SNc e no feixe prosencefálico medial (Kondo et al., 2004). A injeção no feixe prosencefálico medial (FPM) parece ser a mais agressiva e gerar quadros mais semelhantes às fases mais avançadas da doença (revisado por Deumens et al., 2002). Já a injeção intra-estriatal parece ser a menos agressiva e de evolução lenta, sendo a mais utilizada em modelos com estratégias terapêuticas (Blandini et al., 2008). A lesão pode ser induzida em ratos ou camundongos (Beal, 2001; Dauer, Przedborski, 2003). Assim a progressão da doença depende do modelo utilizado. Após injeção local, esta neurotoxina é captada pelas células e promove a produção de radicais livres e disfunções mitocondriais. Ocorre assim inibição dos complexos I e IV da cadeia respiratória mitocondrial, e consequentemente estresse oxidativo, melhor explicado adiante (revisado por Blum et al., 2001). Como resultado final ocorre a morte neuronal devido à ativação de mecanismos apoptóticos dependentes de caspase 3 (Tanaka et al., 2006). A liberação de espécies reativas de oxigênio leva à formação de quinonas que reagem com grupamentos nucleofílicos. A lesão assim produzida não gera corpúsculos de Lewy, típicos do tecido nervoso de pacientes parkinsonianos. Para examinar os déficits funcionais causados pela doença realizam-se testes comportamentais com os animais, para verificar assimetria rotacional e outras disfunções motoras e sensoriais (Blandini et al., 2008; Henderson et al., 2003).

O estresse oxidativo causado pela entrada de 6-OHDA na célula envolve aumento das espécies reativas de oxigênio (EROs); estas por sua vez, induzem excitotoxicidade secundária, pois elevam os níveis de cálcio livre, que, por sua vez, aumenta os níveis de óxido nítrico (NO) intracelular (revisado Blum et al., 2001). A análise de tecidos cerebrais postmortem de pacientes com doenças neurodegenerativas revela alterações na homeostase intracelular de cálcio (revisado por Mattson, 2007). Outro fator que favorece o aumento de radicais livres na degeneração encontrada na DP é a ativação de microglia responsável por produzir NO, citocinas e dinucleótido adenina nicotinamida adenina fosfato (NADPH)-oxidase 
(Blum et al., 2001; Phani et al., 2012). Estudos demonstraram aumento da enzima sintetizadora de NO do tipo induzível (iNOS) no encéfalo de pacientes com DP, enzima que pode estar envolvida em respostas neuroinflamatórias (revisado por Blum et al., 2001). Além da ativação microglial (Wojtera et al., 2005), notamos uma resposta astroglial que também está envolvida com os processos inflamatórios das doenças neurodegenerativas (revisado por Eng et al., 2000; Maragakis, Rothstein, 2006). Assim, estudar os marcadores que se encontram reativos na DP pode ser de extrema importância no desenvolvimento do tratamento, prevenção e progressão das doenças neurodegenerativas.

\subsection{Marcadores de neuroinflamação}

Neste item descreve-se alguns dos mecanismos que estão envolvidos na resposta inflamatória encontrada na $\mathrm{DP}$, tanto em modelos animais quanto em humanos, sendo eles EROs, ativação microglial e astroglial, e aumento da enzima sintetizadora de NO do tipo induzível (iNOS).

\subsubsection{Espécies reativas de oxigênio}

As EROs são essenciais na manutenção da homeostase celular. Em condições fisiológicas as células mantêm o equilíbrio de óxido-redução (redox) por meio da geração e eliminação de EROs. A homeostase redox é crucial para que diversas funções celulares ocorram de maneira adequada, tais como ativação enzimática, síntese de DNA, regulação do ciclo celular e até mesmo apoptose (Kamata, Hirata, 1999). O delicado equilíbrio entre a geração de EROs e a sua decomposição é mantido por mecanismos complexos e a disfunção destes mecanismos pode levar a alterações no equilíbrio redox celular. Um aumento na produção de EROs ou uma diminuição na capacidade de decomposição devido a estímulos metabólicos endógenos e/ou exógenos podem interromper a homeostase redox, levando a um aumento nos níveis de EROs intracelulares ou até mesmo estresse oxidativo (Valko et al., 2007). Em 1985, Sies e Cadenas definiram estresse oxidativo como um desequilíbrio celular no qual os oxidantes predominariam sobre os antioxidantes. Ou seja, quando a produção de EROs excedesse a capacidade 
dos sistemas de defesa antioxidantes, teríamos o estresse oxidativo (Poon et al., 2004; Scandalios, 2002).

Algumas linhas de investigação procuram elucidar o papel do estresse oxidativo nos distúrbios neurodegenerativos, visto que, nestas circunstâncias, observa-se o aumento da formação de EROs (Floyd, 1999; Lee et al., 2009; Phani et al., 2012), por vários mecanismos, como o aumento nos níveis de ferro (catalizador da reação de síntese de EROs), a redução nos níveis de antioxidantes (revisado por Blum et al., 2001) e a ativação da NADPH-oxidase, entre outros. Este complexo enzimático, ao ser ativado, é capaz de produzir uma grande quantidade de radicais superóxido, favorecendo assim, o estresse oxidativo (Phani et al., 2012; Qian et al., 2010). A análise do tecido cerebral postmortem de pacientes com doenças neurodegenerativas como a DP e o mal de Alzheimer revelam claramente o excesso de produção de EROs nas regiões cerebrais mais afetadas pela doença (Dexter et al., 1989; Hensley et al., 1998). Nota-se um aumento nos níveis de superóxido dismutase e diminuição nos níveis de glutationa na SNc, e este desequilíbrio leva à geração do estresse oxidativo (Smith, Zigmond, 2003). Em alguns casos, evidências apontam para o envolvimento de EROs na propagação do dano celular causado pela neuropatologia, levando ao prejuízo oxidativo irreversível dos lipídios, proteínas, DNA e ativação de processos de apoptose (Valko et al., 2007).

Recentemente, alguns estudos têm elucidado o papel do estresse oxidativo no desequilíbrio da homeostase do cálcio, tornando o neurônio mais sensível à excitotoxicidade e apoptose. Níveis elevados de EROs induzem excitotoxicidade secundária, pois elevam os níveis de cálcio livre, que, por sua vez, aumenta os níveis de óxido nítrico (NO) intracelular (revisado por Blum et al., 2001). A análise de tecidos cerebrais postmortem de pacientes com doenças neurodegenerativas revela alterações na homeostase intracelular de cálcio (revisado por Mattson, 2007). Outro fator que favorece o aumento de radicais livres na degeneração encontrada na DP é a ativação de microglia responsável por produzir NO, citocinas e NADPH-oxidase (Phani et al., 2012; Qian et al., 2010). Tendo em vista os danos causados pelo estresse oxidativo, alguns estudos têm focado meios de intervir mecanismos que causam a morte celular. Fujita e colaboradores (2009) demonstraram como possível forma de prevenção da DP a adição de fator antioxidante, hidrogênio, na água de beber de camundongos submetidos ao modelo da DP por MPTP. Neste estudo, os 
animais que beberam água saturada de hidrogênio apresentaram menor perda de neurônios TH-positivos. Associado à diminuição da perda neuronal, houve diminuição da fluorescência por dihidroetidina (DHE), um indicador de estresse oxidativo. Logo, este estudo mostrou que a perda de neurônios dopaminérgicos pode estar relacionada ao desequilíbrio entre fatores oxidantes e antioxidantes no sistema nervoso central (SNC).

\subsubsection{Síntese de óxido nítrico}

O óxido nítrico (NO) participa de diversas funções do SNC, incluindo indução e manutenção da plasticidadde sináptica, liberação de neurotransmissores e remoção de agentes patogênicos (Chen et al., 2004; Dawson et al., 1992). Em situações patológicas, tais como doenças neurodegenerativas, podemos encontrar uma grande concentração de NO capaz de causar respostas tóxicas na célula. A neurotoxicidade está associada à formação de peroxinitrito, devido à reação que ocorre entre o radical livre superóxido com o NO (Kavya et al., 2006). Estudos demonstraram aumento da enzima sintetizadora de NO do tipo induzível (iNOS) no encéfalo de pacientes com DP, enzima que pode estar envolvida em respostas neuroinflamatórias (revisado por Blum et al., 2001).

A síntese de NO ocorre por ação de uma enzima, a óxido nítrico sintetase (NOS), sobre o aminoácido L-arginina, o que produz NO e L-citrulina, necessitando da presença de dois cofatores, o oxigênio e o NADPH. O NO é produzido por uma ampla variedade de tipos celulares que incluem células epiteliais, nervosas, endoteliais e inflamatórias. Existem três formas de NOS, sendo elas a endotelial (eNOS), presentes na membrana de vasos sanguíneos, responsáveis pela regulação da função vascular; a neuronal (nNOS), presente em neurônios e em células endoteliais e estimulada mediante insultos ao SNC; e por último, a enzima que pode ser produzida em diferentes tipos celulares, tem sua transcrição e produção ativada devido situações patológicas, conhecida por forma induzível (iNOS), ausente ou em pouca quantidade em condições fisiológicas (Conti et al., 2007; Knott, Bossy-Wetzel, 2009). Estudos analisaram a expressão de iNOS na DP e revelaram associação entre o acréscimo da enzima com o processo neurodegenerativo na SNc (Hunot et al., 1996; Iravani et al., 2002). Por outro lado, 
estudos com modelos da DP (MPTP e 6-OHDA) revelaram proteção dos neurônios dopaminérgicos após bloqueio não seletivo de NOS (Barthwal et al., 2001) ou específico de iNOS (Broom et al., 2011), bloqueio da enzima inflamatória NADPH oxidase (revisado por Koppula et al., 2012), e em animais knockout para genes de iNOS (Dehmer et al., 2000). Esses dados, apóiam a ideia da participação dessas enzimas nos processos neuroinflamatórios das doenças neurodegenerativas. Por conseguinte, a gestão adequada ou inibição de EROs gerados por essas enzimas podem representar um alvo terapêutico para reduzir a degeneração neuronal observada em DP (revisado por Koppula et al., 2012).

\subsubsection{Proliferação microglial}

As células microgliais, subtipo de células da glia, foram descritas pela primeira vez em 1880 com o desenvolvimento da técnica de Nissl. Em meados de 1920, Pío del Río Hortega , um estudante de Santiago Ramón y Cajal, passou a chamá-la de microglia. Estas células são células diferenciadas do sistema imune residentes no SNC, ou seja, durante o período embrionário monócitos produzidos no sistema sanguíneo migram ao cérebro e diferenciam-se naquelas células. Assim, a microglia é uma variação do macrógafo e possui um alto poder fagocitário responsável pelo remodelamento e maturação cerebral, pois auxilia na limpeza de células em apoptose ou mortas (Wojtera et al., 2005).

No encéfalo maduro, em condições fisiológicas, as células encontram-se pequenas com numerosos prolongamentos ao seu redor, estando em sua forma inativa. Por outro lado, estas células são muito sensíveis e pequenas mudanças no microambiente promovem a sensibilização destas. Ao serem sensibilizadas elas passam a sua forma ativa, assumindo um formato ameboide (Wojtera et al., 2005). A ativação celular promove síntese de substâncias pro-inflamatórias (citocinas), sinalizadores inflamatórios, tais como NO, ou ainda fatores relacionados com a sobrevivência da célula, como o fator neurotrófico derivado da glia (GDNF) (Wojtera et al., 2005). Um dos marcadores utilizados para estudos da microglia é o OX42 ou CD-11-b/c. Este marcador apresenta ligação específica para o receptor C3bi, encontrado em monócitos, macrófagos e microglia (BD550299); assim, o anticorpo é 
capaz de reconhecer tanto a forma inativa quanto a forma ativa da célula (MarinovaMutafchieva et al., 2009).

A microglia funciona como um sensor de eventos patológicos no SNC, estando envolvida nas diversas doenças neurodegenerativas. Em 1988, houve o primeiro relato de proliferação microglial na SNc e CPu de pacientes com DP (McGeer et al., $1988^{1}$ apud Wojtera et al., 2005), e posteriormente, em encéfalos de humanos contaminados por MPTP (Langston et al., 1999). Estas descrições impulsionaram diversos estudos em animais e em humanos para analisar o envolvimento da microglia com a degeneração dos neurônios dopaminérgicos na DP. Em 1998, houve o primeiro relato da proliferação microglial na SNc e CPu após a injeção de LPS diretamente na SNc, um modelo animal que causa rápida degeneração das células (Castano et al., 1998), sendo descrito posteriormente em outros modelos, como por exemplo, de MPTP (Kurkowska-Jastrzebska et al., 1999a,b; Sugama et al., 2003) e de 6-OHDA (Marinova-Mutafchieva et al., 2009; Rodriguez-Pallares et al., 2007).

Sabe-se que ocorre interação entre microglia e o desenvolvimento da DP, tendo em vista que a ativação microglial precede a perda de neurônios dopaminérgicos tanto em humanos (Forno et al., $1996^{2}$ apud Marinova-Mutafchieva et al., 2009; Ouchi et al., 2005) quanto em modelos animais (Cichetti et al., 2002; Marinova-Mutafchieva et al., 2009). Porém, os mecanismos não são bem definidos.

Um dos mecanismos sugeridos para a interação entre microglia e o desenvolvimento da DP é a grande quantidade de microglia presente na SNc. Esta riqueza de células, mediante qualquer alteração do microambiente, é capaz de gerar intensa ativação microglial e consequentemente síntese de substâncias inflamatórias (Kim et al., 2000; McGeer, McGeer, 2004); em contrapartida, os neurônios dopaminérgicos possuem uma capacidade antioxidante limitada, o que pode favorecer defeitos das funções mitocondriais mediante a ativação microglial, e consequentemente a morte neuronal (Greenamyre, Hastings, 2004).

Estudo com tomografia por emissão de pósitrons (PET) em ratos submetidos ao modelo com injeção intra-estriatal de 6-OHDA revelaram aumento da reatividade

\footnotetext{
${ }^{1}$ McGeer PL, Itagaki S, Boyes BE, McGeer EG. Reactive microglia are positive for HLA-DR in the substantia nigra of Parkinson's and Alzheimer's disease brains. Neurology. 1988;38:1285-91.

2 Forno LS. Neuropathology of Parkinson's disease. J Neuropathol Exp Neurol. 1996;55:259-72.
} 
para $\left[{ }^{11} \mathrm{C}\right](\mathrm{R})$ - PK11195, um marcador de microglia ativada, seguido por diminuição da reatividade para $\left[{ }^{11} \mathrm{C}\right] \mathrm{CFT}$, um marcador de transportador de dopamina (DAT), além de diminuição da expressão de TH e aumento da expressão de OX42 em análises de imuno-histoquímica (Cichetti et al., 2002). Estudo clínico, semelhante ao anterior, com pacientes com DP corrobora os dados com animais, ou seja, antes de ocorrer diminuição da ligação de DAT ao radioativo, há uma hiperativação de microglia, reforçando a ideia da participação microglial na progressão da DP (Ouchi et al., 2005). Outro indicio da participação microglial na morte de neurônios dopaminérgicos na DP foi obtido no modelo animal com 6-OHDA. Este estudo relatou que antes de haver diminuição da expressão de $\mathrm{TH}$, há uma intensa proliferação de marcadores microgliais, tais como, OX-42, OX-6, CD-68, sugerindo, assim, uma resposta diretamente proporcional entre a ativação glial e a perda neuronal (Marinova-Mutafchieva et al., 2009).

Vale ressaltar que nem sempre a ativação microglial é deletéria, pois este mecanismo é muito importante nos processos fagocitários para remoção de restos celulares (Glezer et al., 2006; Neumann, 2006; Sriram et al., 2006). Logo, seria de grande relevância o desenvolvimento de intervenções capazes de diminuir a ativação microglial, e consequentemente, efeitos neuroprotetores do SNC.

\subsubsection{Astrócitos}

Os astrócitos são outros subtipos de células gliais, classificadas como células macrogliais do SNC, sendo também conhecidas por astroglia. As funções destas células são diversas e alvos de descrições muito recentes, sendo algumas delas o suporte metabólico, formação da barreira hemato-encefálica e da estrutura cerebral, modulação da transmissão sináptica, potencialização de longo prazo, reparação do sistema nervoso, entre outras que vêm sendo descritas e estudadas. Em nosso estudo, a função de interesse que será descrita adiante é a envolvida com a reparação do sistema nervoso (revisado por Eng et al., 2000).

Um marcador muito utilizado para análise astroglial após lesões, doenças e desenvolvimento do SNC é a proteína acídica fibrilar glial (GFAP). A GFAP foi descrita pela primeira vez por Larry Eng e colaboradores (1971) ao analisar material de pacientes com esclerose múltipla. O GFAP pertence à família de proteínas do 
citoesqueleto, sendo o principal filamento de tamanho intermediário presente em astrócitos maduros. Esta proteína é importante na modulação da mobilidade e da forma do astrócito, e é expressa em todo o SN, principalmente após lesões encefálicas.

Estudos "in vivo" e "in vitro" demonstraram aumento da ativação astroglial em diferentes modelos animais, tais como encefalomielite alérgica experimental (EAE modelo de esclerose múltipla), modelos de epilepsia (cainato), e modelos da DP (6hidroxidopamina, 1-metil-4-fenil-1, 2,3,6-tetrahdropyridine (MPTP). Nestes modelos, os astrócitos tornam-se reativos e respondem de maneira típica, fenômeno conhecido por astrogliose. A astrogliose é caracterizada por rápida síntese de filamentos de GFAP próximo ao local da lesão. Assim, o GFAP é um biomarcador sensível e precoce da neurotoxicidade (revisado por Eng et al., 2000).

Apesar de animais knockouts serem viáveis, estudos demonstraram que estes ratos apresentam hipersensibilidade a lesões na medula espinal e uma redução na estabilidade citoarquitetônica do astrócito. Estudo com o modelo de esclerose múltipla demonstrou que animais GFAP-/- apresentaram pior quadro clínico em relação aos animais selvagens, apesar da remielização axonal ocorrer nos animais knock-outs (Liedtke te al., 1998).

O aumento de GFAP nos astrócitos ocorre gradualmente ao longo da vida adulta. Porém, mudanças astrocitárias, tais como proliferação intensa e rápida em regiões anatômicas específicas, parece estar envolvida com doenças neurodegenerativas, por exemplo, esclerose lateral amiotrófica (ELA), doença de Huntington, DP e DA (Calne, 1994). Assim, a intensidade da síntese de GFAP parece estar envolvida no controle clínico da doença após a ativação astroglial, sugerindo a participação deste filamento nos processo de neuroproteção e recuperação do SN após danos encefálicos (Dutra et al., 2012).

Estudos com o modelo da DP induzido por 6-OHDA demonstraram que a diminuição da expressão de GFAP pode estar relacionada com a melhora motora de animais treinados em esteira (Dutra et al., 2012) e com o efeito neuroprotetor encontrado após o tratamento com NK1 (um antagonista do receptor de substância $P$, sendo a substância $P$ um importante mediador da neuroinflamação) (Thornton, Vink, 2012). Assim, existem evidências da participação dos astrócitos em doenças 
neurodegenerativas, porém os mecanismos envolvidos ainda são pouco compreendidos.

\section{$\underline{1.5 \text { Exercício físico }}$}

O exercício físico é um comportamento relativamente simples e muito praticado pelos humanos, capaz de ativar cascatas moleculares e celulares responsáveis pelo suporte e manutenção da plasticidade cerebral (Cotman, Berchtold, 2002) e inversamente relacionado com doenças neurodegenerativas. Portanto, tem sido foco de diversos estudos, tanto com animais quanto em humanos, que visam descrever benefícios ao sistema nervoso. Alguns efeitos já foram descritos, tais como melhora no aprendizado, na memória e na plasticidade neural (Lambert et al., 2005; Molteni et al., 2004a; Vaynman et al., 2004). Observouse também um efeito protetor do exercício no sistema nervoso, atenuando o declínio mental decorrente do envelhecimento (Kronenberg et al., 2006; Mattson, 2000; Sumic et al., 2007), aumentando a resistência a lesões (Chen et al., 2007) e facilitando a recuperação funcional pós-lesão (Lacerda et al., 2007; Mattson, 2000). Estudos sugerem diminuição do risco de desenvolver a DP (Chen et al., 2005; Logroscino et al., 2006; Wu et al., 2011), ou ainda, um efeito neuroprotetor sobre os neurônios dopaminérgicos com a prática do exercício (Lau et al., 2011; Petzinger et al., 2007; Tajiri et al., 2010; Yoon et al., 2007). Há ainda trabalhos que demonstram proliferação celular e neurogênese no giro denteado do hipocampo em protocolos de exercício (Kempermann et al., 1998, 1997; van Praag et al., 2008, 1999).

Estudos com modelos animais da DP têm mostrado diversos processos plásticos, desencadeados pelo exercício físico, envolvidos com mecanismos de neuroproteção, tais como melhora da angiogênese (Al-Jarrah et al., 2010), incremento de respostas anti-inflamatórias (Cadet et al., 2003) e decréscimo das inflamatórias (Wu et al., 2011), melhora das funções mitocondriais (Lau et al., 2011), aumento da neurogênese no CPu (Tajiri et al., 2010) e na SNc (Steiner et al., 2006), diminuição de danos oxidativos (revisado por Radák et al., 2008; Radák et al., 2001) e de mecanismos que ativam a neurodegeneração, como a proliferação astroglial (Dutra et al., 2012). Essas respostas plásticas parecem estar diretamente relacionadas às melhoras nos déficits neuroquímicos, cognitivos e motores (Cohen 
et al., 2003; Lau et al., 2011; O'Dell et al., 2008; Petzinger et al., 2007; Sutoo et al., 2003; Tajiri et al., 2010; Yoon et al., 2007; Wu et al., 2011).

O efeito neuroprotetor do exercício em modelos da DP foi relatado em ratos submetidos ao movimento forçado do membro anterior 7 dias antes da injeção (Cohen et al., 2003), em ratos treinados em esteira (Lau et al., 2011; Petzinger et al., 2007; Tajiri et al., 2010; Tillerson et al., 2003; Yoon et al., 2007; Wu et al., 2011) e submetidos a protocolos de exercício voluntário em roda (O’Dell et al., 2007), diminuindo os déficits neuroquímicos, aumentando a produção de tirosinahidroxilase e do DAT, além da melhora do comportamento motor.

O exercício intenso em esteira demonstrou, em camundongos submetidos ao modelo com MPTP, aumento na liberação de DA no CPu e melhora da performance motora no rotarod. Possivelmente, estas melhoras devem-se ao aumento nos níveis de TH e do DAT, apesar de não haver alterações no RNA mensageiro (Petzinger et al., 2007). O exercício de intensidade leve, por 14 dias consecutivos em esteira, também foi capaz de promover efeitos no modelo induzido por injeção intra-estriatal de 6-OHDA; notou-se diminuição nos déficits de TH e do comportamento rotacional induzido por injeção de apormorfina (Yoon et al., 2007). Por outro lado, o exercício voluntário em roda, 2 1⁄2 semanas antes e 4 semanas depois da injeção intracerebral de 6-OHDA, demonstrou melhora motora dos animais sem que houvesse respostas neuroprotetoras, ou seja, houve diminuição da expressão de DAT e TH semelhantes aos animais sedentários (O’Dell et al., 2007).

Em adição aos relatos da melhora neuroquímica e comportamental, promovidos pelo exercício, alguns estudos têm investigado a participação de fatores neuroinflamatórios responsáveis por ativar mecanismos neurodegenerativos, tais como ativação microglial, ativação astroglial, aumento da síntese de NO e EROs.

Estudos que correlacionam a ativação microglial com a DP e o exercício físico são controversos. Um deles demonstrou que o exercício em esteira não afeta a ativação microglial no modelo da DP induzida por LPS, mas promove proteção das células dopaminérgicas (Wu et al., 2011). Por outro lado, um estudo com o modelo de MPTP revelou diminuição da proliferação microglial, assim como da expressão de iNOS após 4 semanas de treino em esteira (Sung et al., 2012). Porém, vale ressaltar que o protocolo com LPS promoveu uma resposta inflamatória rápida e sistêmica, podendo não reproduzir idealmente a situação na DP. 
Além da diminuição da ativação microglial, o exercício também é capaz de diminuir a ativação astroglial, em modelo com 6-OHDA, após 1 hora de treino em esteira, por 4 semanas, 5x/semana. A diminuição na proliferação de astrócitos parece estar envolvida na melhora motora dos animais, tendo em vista que não houve mudanças na expressão de TH quando comparados os animais sedentários com os treinados (Dutra et al., 2012).

Há também mudanças na produção de EROS após o exercício, importante no controle de estresse oxidativo promovido pelas doenças neurodegenerativas (revisado por Radak et al., 2008; Radák et al., 2001). Porém, os dados são controversos; o treino intenso de ratos saudáveis em esteira 1 hora/dia, por 8 semanas, 5x/semana, é capaz de aumentar marcadores de EROs (Radák et al., 2013), parecendo esta ser uma resposta adaptativa aguda que estimula a síntese de enzimas antioxidantes e reparação tecidual, pois não se observam lesões no SNC após aquele aumento (Radák et al., 2002, 2001). Por outro lado, o exercício moderado diminui a geração de EROs, como observado no hipocampo de ratos idosos (Marosi et al., 2012) e em modelos de epilepsia (Kim et al., 2011). O exercício parece ser capaz de alterar o estado antioxidativo e redox do encéfalo (Somani et al., 1996, 1995), sendo capaz de diminuir o estresse oxidativo e assim diminuir a incidência de doenças neurodegenerativas (Holloszy, Kohrt, 1995). Apesar das evidências da participação de EROs no desenvolvimento da DP e os efeitos do exercício físico sobre a sua produção, não existem estudos que relacionem diretamente os efeitos do exercício físico sobre a geração de EROs na DP.

Além das descrições em modelos animais, estudos clínicos relatam que a etiologia da DP está relacionada ao estilo de vida das pessoas, sendo mais propícias a desenvolver doenças neurodegenerativas as pessoas sedentárias (Chen et al., 2005; Elbaz, Moison, 2008; Olanow, Tatton, 1999). Em pacientes que já apresentam os quadros clínicos da DP há uma melhora na qualidade de vida, na deambulação (Herman et al., 2007), na coordenação motora (Fischer et al., 2008), equilíbrio (Toole et al., 2000), no tremor e na força de preensão (revisado por Goodwin et al., 2008; Palmer et al., 1986) após o exercício físico. Com a melhora motora há uma diminuição das quedas nos pacientes (Goodwin et al., 2011) e diminuição da taxa de mortalidade (Kuroda et al., 1990, 1992). 
Um estudo com pacientes em estágios iniciais da DP relatou, após 24 sessões de exercício em esteira, normalização da excitabilidade córtico-motora e melhora no desempenho funcional. A melhora funcional parece estar relacionada com o aumento na velocidade da marcha, alargamento da passada e aumento na mobilidade do quadril e tornozelo, responsáveis pela melhor distribuição de peso corporal durante as tarefas de sentar e levantar (Fisher et al., 2008).

\subsubsection{Fator neurotrófico derivado do encéfalo}

É possível que os principais responsáveis pelos efeitos neuroprotetores do exercício físico, descritos acima, sejam fatores neurotróficos, tais como o fator neurotrófico derivado do encéfalo (BDNF). Esses fatores são essenciais na diferenciação celular, sobrevivência neuronal, migração, arborização dendrítica, sinaptogênese e plasticidade sináptica, agindo através dos receptores tirosina quinase B (TrkB) (Cotman, Berchtold, 2002). A expressão de BDNF está diminuída em modelos animais da DP (Lau et al., 2011; Tajiri et al., 2010; Wu et al., 2011) e em cérebros de pacientes parkinsonianos postmortem (Howells et al., 2000). Por outro lado, o exercício físico é capaz de recuperar os níveis de BDNF tanto em modelos animais (Lau et al., 2011; Smith, Zigmond, 2003; Tajiri et al., 2010; Wu et al., 2011) quanto em pacientes com a DP (Ahlskog, 2011).

Estudos in vitro demonstraram que o fator neurotrófico neuronal (NGF) e o BDNF têm papel neuroprotetor mediante estímulos neurotóxicos que ativam vias de apoptose encontradas em doenças neurodegenerativas (Nguyen et al., 2009), sendo diminuído este efeito após adição de K252a (inibidor seletivo da transdução de mecanismos das neurotrofinas (Knüsel, Hefti, 1992). Estudo eletrofisiológico no hipocampo demonstrou que a adição de BDNF a células em cultura promoveu a rápida excitação do receptor TrKB, enquanto a adição da proteína bloqueadora de TrK (K252a) foi capaz de inibir a ativação destes receptores por BDNF (Kafitz et al., 1999). Molteni e colaboradores (2004b) demonstraram que a atividade voluntária é capaz de aumentar a regeneração axonal de neurônios sensoriais periféricos, porém a regeneração é dependente de fatores neurotróficos, pois a adição de K252a promoveu diminuição da regeneração mesmo no animal treinado (Molteni et al., 2004b). 
A possível participação do BDNF nos efeitos neuroprotetores também foi descrita em modelos da DP, tanto em estudos que aplicaram BDNF exógeno nos animais (Wu et al., 2011; Singh et al., 2006) quanto em protocolos de exercício capazes de restaurar os níveis de BDNF (Lau et al., 2011; Tajiri et al., 2010; Wu et al., 2011). O tratamento com BDNF antes da aplicação intra-estriatal de 6-OHDA demonstrou recuperação comportamental do sistema dopaminérgico, sugerindo um efeito preventivo do desenvolvimento da DP (Singh et al., 2006). Estudo mais recente com o modelo moderado crônico de DP induzido por administração de MPTP em camundongos revelou que exercício em esteira por 18 semanas (1 semana antes de injetar MPTP, 5 semanas durante a administração e 12 semanas após a indução completa da DP), foi capaz de diminuir os déficits de neurônios dopaminérgicos $(\mathrm{TH})$, de DA e do DAT, elevar os níveis de fatores neurotróficos no circuito nigroestriatal (BDNF e GDNF), e melhorar a função mitocondrial, protegendo, assim, as células de danos oxidativos causados pela neurotoxina (Lau et al., 2011). Estudo com o modelo de 6-OHDA também demonstrou efeito neuroprotetor do exercício em esteira. A prática de 30 minutos de exercício, 5x/semana por 4 semanas, foi capaz de recuperar os níveis de BDNF no estriado, mecanismo que deve estar diretamente envolvido com a preservação das células TH-postivas na $\mathrm{SNc}$ e dos terminais axonais no $\mathrm{CPu}$, além do aumento da migração de células $\mathrm{BrDu}$ e doublecortina-positivas para a região lesada do CPu (Tajiri et al., 2011).

Para confirmar o envolvimento do BDNF nesses efeitos, e não outros mecanismos que podem estar envolvidos com o exercício, um grupo comparou os efeitos neuroprotetores promovidos pelo exercício e pelo tratamento exógeno com BDNF. Para isto, antes da injeção de LPS, um grupo de camundongos foi treinado em esteira, $5 x /$ semana por 4 semanas, e o outro grupo foi tratado com injeção de BDNF no CPu. Estes animais foram sacrificados após 5 semanas da indução do modelo da DP com LPS, e as análises histológicas revelaram melhora na expressão de tirosina hidroxilase, com níveis semelhantes aos encontrados em animais exercitados (Wu et al., 2011). Por outro lado, a injeção intracerebroventricular do bloqueador do receptor de BDNF, K252a, em ratos treinados, antes da injeção de LPS, promoveu déficits na expressão de TH (Wu et al., 2011), assim como em camundongos knockout para TrkB (Baydyuk et al., 2011). 
Apesar dos estudos mencionados acima reforçarem a ideia do envolvimento do BDNF na neuroproteção induzida pelo exercício, outros protocolos de estudos são necessários para analisar estratégias terapêuticas da DP em fases mais iniciais da doença. Por exemplo, a injeção intraperitoneal de LPS promove uma resposta inflamatória sistêmica rápida e intensa, capaz de ativar resposta microglial na SNc e outras regiões do encéfalo (Dutta et al., 2008; Wu et al., 2011), resultando em morte severa de células TH-positivas, simulando fases mais tardias da doença (Wu et al., 2011).

Deve-se ressaltar que estudos clínicos revelam aumento do BDNF no soro de pacientes com DP após protocolos de exercício físico. Este fator, por sua vez, é capaz de atravessar a barreira hemato-encefálica e desempenhar seu papel neuroprotetor no SNC (Ahlskog, 2011). 


\subsection{Justificativa}

Os processos de neurodegeneração representam um tema importante na neurociência, sendo a DP um grande alvo das pesquisas, pois acomete milhões de indivíduos no mundo todo, sendo que o número de doentes deve duplicar ao longo dos próximos 20 anos. Logo, é de extrema importância o desenvolvimento de estudos que visam possíveis estratégias de tratamento e prevenção da DP.

O exercício é um comportamento simples e amplamente praticado pelos seres humanos. Os efeitos benéficos do exercício sobre o SNC e outros sistemas foram descritos por diversos autores nos últimos anos, inclusive sobre a DP. Porém, pouco se sabe sobre os mecanismos envolvidos, e qual seria o melhor protocolo de exercício a ser utilizado. Sabe-se que o exercício ativa cascatas moleculares e celulares que suportam e mantêm a plasticidade do cérebro (Cotman, Berchtold, 2002), e está inversamente relacionada com as doenças neurodegenerativas. No entanto, a extensão da lesão e do tipo de exercício (voluntário ou forçado) pode afetar a resposta neuroprotetora e comportamental induzido pelo exercício físico (Alonso-Frech et al., 2011;. Hirsch, Farley, 2009).

Além disso, não existem estudos na literatura que demonstram os efeitos do exercício intermitente em esteira em modelos animais da DP. O exercício intermitente, proposto neste estudo, parece ser mais viável na rotina de pacientes parkinsonianos e não atletas, que normalmente praticam atividade física 3 ou 4 vezes por semana (Herman et al., 2007). Logo, o presente protocolo de exercício parece ser mais próximo da realidade dos pacientes com DP.

Assim, a relevância deste estudo destaca-se pela contribuição do mesmo em tentar esclarecer os mecanismos envolvidos na progressão e possível proteção promovida pelo exercício intermitente em esteira no desenvolvimento da patologia. 


\subsection{Objetivo Geral}

Analisar os possíveis efeitos do exercício físico intermitente em esteira sobre as mudanças comportamentais, histológicas e neuroquímicas no modelo unilateral da DP induzido por injeção intraestriatal de 6-OHDA, e o papel do BDNF nos efeitos promovidos pelo exercício.

\subsubsection{Objetivos específicos}

(1) avaliar o papel do BDNF nos possíveis efeitos protetores promovidos pelo exercício (capítulo 4);

- avaliar o efeito do protocolo de exercício sobre o comportamento motor pelos testes de rotação induzida por apomorfina e campo aberto;

- avaliar o efeito do protocolo de exercício sobre o processo neurodegenerativo das células dopaminérgicas com análise da expressão da enzima limitante da síntese de DA (tirosina-hidroxilase - TH) pelas técnicas de imunohistoquímica e immunoblotting;

- avaliar o efeito do protocolo de exercício sobre a expressão do fator neurotrófico derivado do encéfalo (BDNF) por immunoblotting.

- avaliar o envolvimento do BDNF sobre os efeitos do exercício através da análise comportamental e da expressão de TH após o bloqueio do receptor de BDNF (TrkB) com K252a;

(2) avaliar o possível efeito preventivo do exercício físico na neurotoxicidade induzida pela injeção intraestriatal de 6-OHDA em ratos treinados (capítulo 5);

- avaliar o efeito preventivo do protocolo de exercício sobre o comportamento motor pelo teste de rotação induzida por apomorfina após 30 dias da injeção de 6OHDA em ratos previamente treinados;

- avaliar o efeito preventivo do protocolo de exercício sobre o processo de degeneração das células dopaminérgicas com análise da expressão de TH pelas técnicas de imuno-histoquímica e immunoblotting; 
- avaliar respostas neuroinflamatórias, a curto prazo (7 dias após a indução da DP), que podem estar envolvidas com os efeitos do exercício após a injeção de 6-OHDA, tais como proliferação astrociária (GFAP), ativação microglial (OX42), e síntese de óxido nítrico (iNOS), pelas técnicas de imuno-histoquímica e immunoblotting;

- avaliar a expressão de BDNF pelo método de ELISA;

- avaliar a geração de espécies reativas de oxigênio (EROs) pela análise da fluorescência derivada dos produtos de oxidação da dihidroetidina (DHE);

- avaliar o envolvimento do BDNF sobre o efeito protetor do exercício através da análise comportamental e da expressão de TH após o bloqueio do receptor de BDNF (TrkB) com K252a; 


\section{CAPÍTULO 2 - MATERIAL E MÉTODOS}

\subsection{Animais}

Foram utilizados nos experimentos 212 ratos machos da linhagem Wistar (2 a 4 meses de idade) fornecidos pelo biotério central do Instituto de Ciências Biomédicas da USP. Os animais foram mantidos em uma sala com ciclo claro/escuro invertido artificialmente controlado de $12 / 12 \mathrm{~h}$. Os animais foram alimentados com ração padrão e água ad libitum. A temperatura foi mantida a $23^{\circ} \mathrm{C}$. Antes do início do treinamento físico os animais ficaram pelo menos 15 dias na sala para adaptação ao ciclo invertido (Campos et al., 2006; Salgado-Delgado et al., 2008). Este estudo foi conduzido de acordo com os Princípios Éticos de Experimentação Animal adotado pelo Colégio Brasileiro de Experimentação Animal (COBEA) e foi aprovado pela COMISSÃO DE ÉTICA EM EXPERIMENTAÇÃO ANIMAL (CEEA) do ICB/USP em 20/02/2009, protocolo registrado sob no 14 na fl. 67 do livro 2 para uso de animais em experimentação.

\subsection{Procedimento cirúrgico}

Tendo em vista que a 6-OHDA não cruza a barreira hemato-encefálica, esta deve ser administrada estereotaxicamente, por microinfusão, no próprio corpo estriado $(\mathrm{CPu})$ para efetuar uma lesão retrógrada dos neurônios nigro-estriatais (revisado por Blum et al., 2001). Após diversos testes, definimos fazer injeções de $6 \mu \mathrm{g} / \mu \mathrm{l}$ da droga, sendo 2 injeções de $0,5 \mu \mathrm{l}$ em 2 coordenadas distintas, a saber: (1) L: 2,7 mm; AP: bregma; V: 4,5 mm; (2) L: 3,2 mm; AP: 0,5 mm; V: 4,5 mm. Logo, em cada ponto injetaram-se $3 \mu \mathrm{g}$ da droga. Os dois pontos de injeção tiveram o objetivo de garantir que tanto áreas rostro-caudais, médio-laterais como ventro-dorsais do CPu fossem atingidas pela droga.

Os animais foram anestesiados com tribromoetanol a 2,5\% (1 ml/100 g - 250 $\mathrm{mg} / \mathrm{Kg}$, i.p.) (Animal Welfore Committee - National Health Medical Research Council on 14/03/2002; Cecanho et al., 1999; Turgeon, Waring, 2006; Vilela, 2008 Waynforth, Flecknell, 1992). Com os animais anestesiados foi realizada a fixação destes no aparelho estereotáxico (Figura 3). Os animais permaneceram o tempo 
todo com bolsas de água quente dos lados para evitar hipotermia; os ratos receberam ainda no local da incisão um anestésico local associado a um coagulante para diminuir o sangramento local (lidocaína + epinefrina). Após a craniotomia com auxílio de uma broca de baixa rotação, segundo coordenadas estereotáxicas da estrutura-alvo - CPu (Paxinos, Watson, 2005), uma micropipeta foi introduzida no encéfalo. A micropipeta passa pela perfuração feita com a broca e atinge a estrutura cerebral desejada. A agulha foi fixada a um suporte conectado a uma bomba microinfusora para infusão da droga, 6-OHDA (6-OHDA Hydrochloride-H4381Sigma®, Saint Louis, MO, USA) diluída em salina e 0,3\% de ácido ascórbico (diminui a oxidação da droga), ou de salina. Depois de terminada a infusão, a agulha foi mantida na região infundida por alguns minutos para evitar o refluxo da solução, e então foi lentamente removida do crânio. Finalizada a infusão, a incisão foi suturada e os animais mantidos em caixas individuais com bolsas de água quente próximas ao corpo para recuperação da anestesia. Ao recuperar-se da anestesia, os animais foram colocados em caixas com outros 3 animais, não sendo necessário alimentálos. No segundo dia após a injeção os animais que seriam treinados iniciaram a atividade em esteira. No grupo K252a, $1 \mu$ das microesferas (preparação descrita abaixo - tópico 2.3), foi associado à neurotoxina para serem injetadas no CPu.

Figura 3 - Imagens digitais ilustrando o animal fixado ao aparelho estereotáxico.
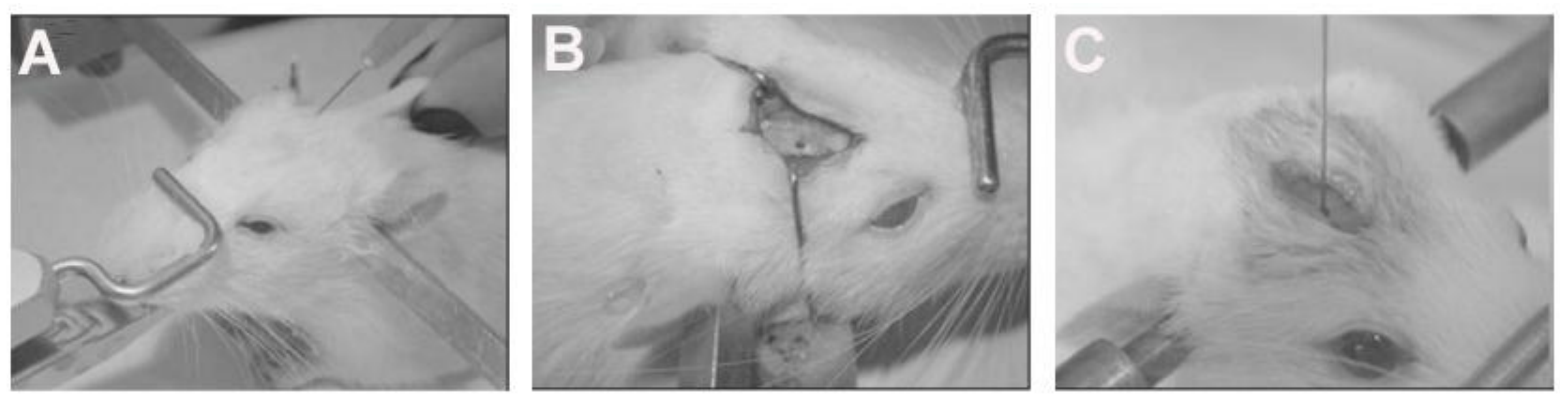

A- animal fixado ao aparelho. B- Abertura feita para injeção da neurotoxina. C- introdução da micropipeta contendo a neurotoxina na coordenada escolhida.

Fonte: Modificado de Michailowsky e colaboradores (2003) 


\subsection{Preparação das microesferas com K252a}

Para a preparação das microesferas utilizou-se como referência o protocolo utilizado por outros autores (Lom, Cohen-Cory, 1999; Riddle et al., 1997; Vaynman et al., 2004). As microesferas fluorescentes de latex na cor vermelha (Lumaflor, Naples, FL, USA) foram primeiramente incubadas por 6 horas em temperatura ambiente com um trocador de íons (10\% peso/volume - AG® 501-X8 Mixed Bed Resin (Bio-Rad, Hercules, CA, USA). Em seguida, as microesferas ficaram incubadas overnight em uma mistura de $1: 5$ (microesferas para K252a) a $4 \stackrel{\circ}{\circ}$. A

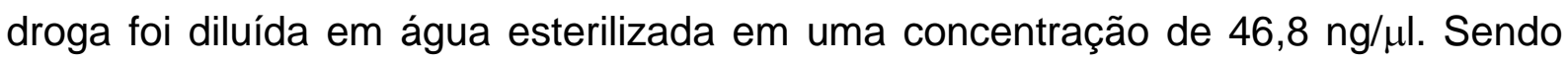
assim, as microesferas foram carregadas com a droga através de absorção passiva. No dia seguinte, a mistura foi centrifugada a $100.000 \mathrm{~g}$ por 1 hora e 30 minutos. $O$ sobrenadante foi descartado e o pellet (onde estavam as microesferas) foi ressuspendido em água esterilizada em uma concentração de $10 \%$. Ridlle e colaboradores (1997), descrevem que a liberação de droga ocorre por pelo menos 4 dias após a injeção na região cerebral escolhida. Para constatar se as microesferas chegavam à $\mathrm{SN}$ injetamos as microesferas no $\mathrm{CPu}$ e após 3 dias o animal foi anestesiado, perfundido, os encéfalos foram fixados e crioprotegidos, como descrito no item 4.6.2. Alguns cortes de encéfalo do animal foram colocados em lâminas gelatinizadas. Os cortes foram analisados em microscópio de fluorescência e as imagens foram capturadas e salvas para ilustração.

\subsection{Protocolo de exercício físico}

Os animais foram treinados em uma esteira ergométrica programável (KT 3000 - IMBRAMED) adaptada para ratos (Figura 4). A esteira é constituída de 8 raias de acrílico transparente.O protocolo de exercício consistiu de corrida em esteira 3x/semana, durante 40 minutos, a uma velocidade de $10 \mathrm{~m} / \mathrm{min}$ (Garcia et al., 2012). Logo, o animal percorreu cerca de $1200 \mathrm{~m} / \mathrm{semana}$. Este protocolo atinge aproximadamente $60 \%$ do $\mathrm{VO}_{2}$ máximo (Felix, Michelini, 2007), assim, trata-se de um treinamento de intensidade leve/moderado.

Antes do início do protocolo os animais foram selecionados através da adaptação ao exercício por 15 minutos durante 2 dias. A adaptação foi iniciada a 
uma velocidade de $5 \mathrm{~m} / \mathrm{min}$ com incrementos da velocidade de $1,7 \mathrm{~m} / \mathrm{min}$ a cada 5 minutos. Desta forma, ao fim do treino, os animais estavam a uma velocidade de 8 $\mathrm{m} / \mathrm{min}$. Neste período, os animais que se recusaram a correr foram excluídos do estudo. Após a adaptação, os animais foram distribuídos aleatoriamente em dois grupos, os sedentários (SED) e os exercitados (EX).

O ratos do grupo EX foram subdivididos em 3 protocolos de exercício, sendo eles:

(1) Exercício 4 semanas antes e 4 semanas depois da indução da DP (EXA+EXD). O objetivo deste protocolo foi investigar se o exercício físico era capaz de promover algum tipo de proteção contra o desenvolvimento da DP (Chen et al., 2005; Sasco et al., 1992) (Capítulo 4).

(2) Exercício apenas 4 semanas depois da indução da DP (EXD). O objetivo foi avaliar se o exercício físico é capaz de promover benefícios após o início da DP (Fisher et al., 2008; Herman et al., 2007) (Capítulo 4).

(3) Exercício 4 semanas antes da indução da DP (EXA). O objetivo foi analisar o efeito preventivo do exercício no desenvolvimento da DP (Chen et al., 2005; Sasco et al., 1992) (Capítulo 5).

O horário de início do treinamento foi o mesmo para todos os grupos, acontecendo no período ativo do animal (10 - $14 \mathrm{~h})$, pois os animais ficaram em sala com ciclo invertido (Holmes et al., 2004; Salgado-Delgado et al., 2008), o que diminui o estresse do exercício em esteira (Arida et al., 2011). Os animais do grupo CTL e SED ficaram na caixa própria para ratos ao lado da esteira sem realizar atividade física, apenas sob o efeito do barulho da esteira e manipulação, sendo colocados na esteira sem que esta fosse ligada, apenas para controle do estresse da manipulação.

O exercício em esteira é amplamente utilizado, pois é relativamente simples de ser executado e muito efetivo. Este protocolo permite o treino de diversos animais ao mesmo tempo, e é capaz de promover o treino aeróbico e anaeróbico ao mesmo tempo. Além disso, o animal é forçado a correr de acordo com a demanda do pesquisador, assim, um protocolo de exercício com frequência, duração e intensidade pré-definidas (Arida et al., 2011). 
Figura 4 - Imagens digitais da esteira ergométrica adaptada para ratos.
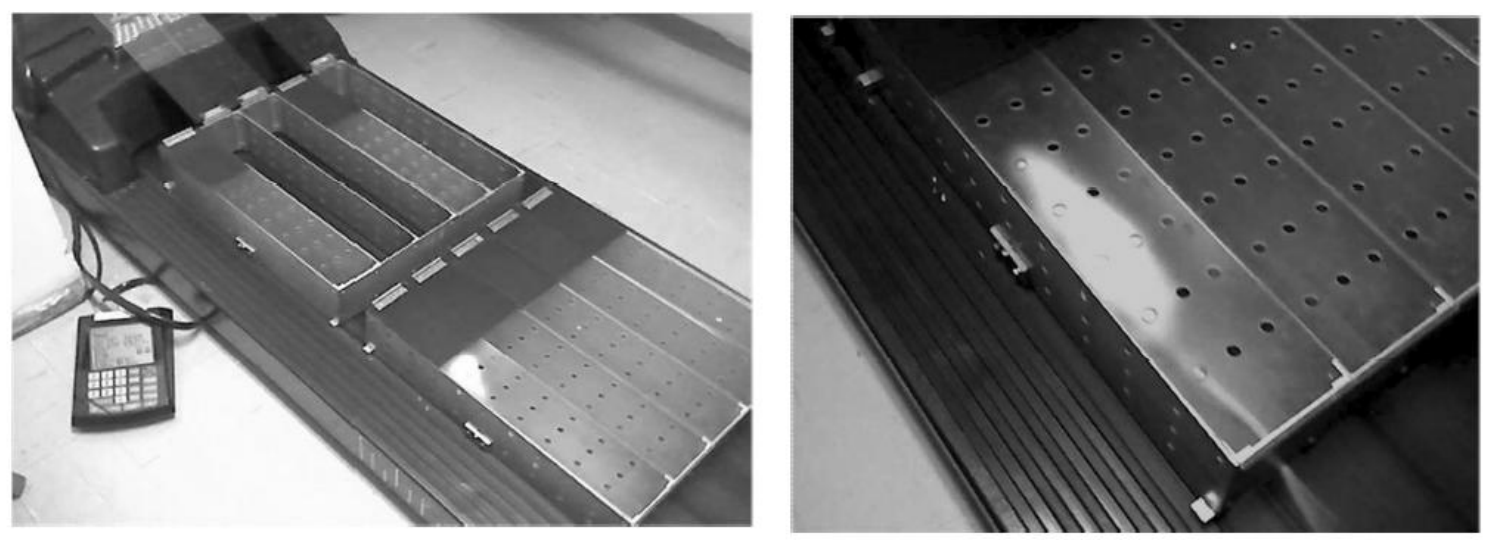

Fonte: Modificado de Ferreira (2011)

\subsection{Qualificação e quantificação da lesão parkinsoniana}

\subsubsection{Análise Comportamental}

\subsubsection{Campo aberto}

Uma das formas de análise do comportamento dos animais foi através do teste no campo aberto (CA), o qual permite a avaliação do comportamento exploratório dos ratos. Os animais foram colocados em um CA circular $(86 \mathrm{~cm}$ de diâmetro), duas vezes após a injeção de 6-OHDA (7 e 28 dias após a injeção), por um período de $5 \mathrm{~min}$. Com 7 dias de lesão o animal foi exposto ao ambiente pela primeira vez. O animal era colocado no centro do círculo (Figura 5A) e sua atividade locomotora foi analisada, ou seja, a quantidade de vezes que o animal entrava com as quatro patas em uma das sub-áreas delimitada no CA (Figura 5B) (Andringa et al., 2000; Bowenkamp et al., 1997; Broadhurst, 1960). 
Figura 5 - Imagens digitais ilustrando o teste de ratos em campo aberto.
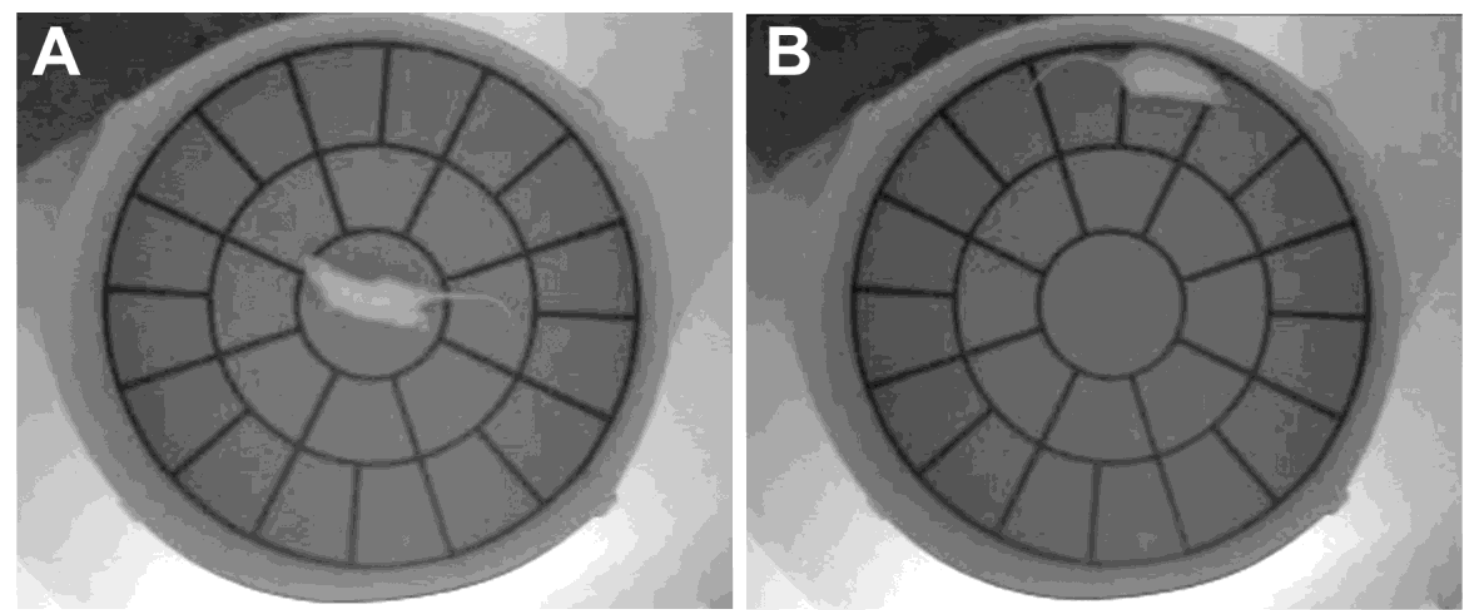

A- Posição inicial do animal no teste do CA. B - frequência de locomoção (quantidade de vezes que o animal entrava em cada sub-área delimitada no $\mathrm{CA}$ ).

\subsubsection{Teste de Rotação}

O comportamento rotacional dos animais foi avaliado utilizando um rotômetro automático (Rota-Count 8, Columbus Instruments), sendo um teste muito utilizado para indicação do grau de lesão dos neurônios dopaminérgicos na DP (Kirik et al., 1998). Os animais foram injetados com o agonista de DA, apomorfina $(0,5 \mathrm{mg} / \mathrm{kg}$, subcutâneo) (Blandini et al., 2008; Jin et al., 2008) e avaliados durante $30 \mathrm{~min}$. O critério para a rotação foi um giro de $360^{\circ}$ para um dos lados. Esperava-se que 0 animal lesado rodasse para o lado contralateral ao hemisfério lesado, ou seja, para o lado esquerdo (Henderson et al., 2003; Kirik et al. 1998).

Este teste foi realizado um dia antes do sacrifício dos animais, ou seja, 29 dias após a injeção de 6-OHDA. Os animais foram fixados no aparelho através de um colete próprio (Figura 6). 
Figura 6 - Imagem do rato fixado ao rota count.



Após a injeção subcutânea de apomorfina o animal apresenta um comportamento rotatório assimétrico que é quantificado pelo aparelho ilustrado.

\subsubsection{Protocolo de imuno-histoquímica}

Os animais ( $n=5 /$ grupo) foram anestesiados e submetidos à perfusão transcardíaca, com solução salina $0,9 \%$, seguida de solução fixadora constituída de paraformaldeído $4 \%$ dissolvido em tampão fosfato $0,1 \mathrm{M}$ (PB, pH 7,4). Após a perfusão, os encéfalos foram coletados e armazenados em paraformaldeído $4 \%$ por 4 horas. Após este período, o material foi transferido para uma solução crioprotetora de sacarose a $30 \%$ em PB. Após 24 horas, os tecidos foram cortados em uma espessura de $30 \mu \mathrm{m}$ em um micrótomo deslizante de congelamento.

Os cortes histológicos foram colocados em placa de cultivo, em solução tampão (PB 0,1 M), e mantidos em geladeira a $4 \stackrel{\circ}{\circ} \mathrm{C}$ até o momento do procedimento de imuno-histoquímica. Os cortes da $\mathrm{SNc}$ e $\mathrm{CPu}$ foram selecionados e submetidos à metodologia de imunoperoxidase com anticorpos específicos para detecção de marcadores de interesse feitos em camundongo, sendo eles, enzima limitante da síntese de DA, tirosina-hidroxilase (TH) (1:2000 - Chemicon - Millipore - MAB5280); proteína acídica fibrilar glial (GFAP) (1:1000 - Immunon Shandon - 410745); marcador de microglia OX42 ou CD11b/c (1:1000 - BD550299). Os cortes restantes foram estocados em solução anti-freezing (PB 0,05 M, sacarose e etilenoglicol) a -20 $\stackrel{\circ}{\circ}$. 
Os cortes foram lavados em tampão fosfato (PB 0,1 M) por três vezes de 10 minutos, e foram então incubados com anticorpos primários específicos citados acima, em PB com 0,3\% de Triton X-100 e 5\% de soro normal do animal que foi produzido o secundário, ou seja, soro normal de jumento (normal donkey serum NDS). Os cortes foram incubados por um período de 14 a 18 horas à temperatura ambiente $\left(24^{\circ} \mathrm{C}\right)$.

Os cortes foram lavados novamente em tampão fosfato à temperatura ambiente e incubados por duas horas com anticorpo secundário biotinilado contra as imunoglobulinas do animal no qual foi feito o anticorpo primário, ou seja, anti camundongo feito em jumento ( $\alpha-\mathrm{ms} \mathrm{dk}$ b) em uma concentração de 1:200. Após nova série de lavagens à temperatura ambiente, os cortes foram colocados por duas horas numa solução de Triton X-100 0,3\% em tampão fosfato 0,1 M com 0,4 M de $\mathrm{NaCl}$, contendo o complexo avidina-biotina-peroxidase (ABC ELITE kit, Vector Labs., Burlingame, CA, EUA). Após nova série de lavagens, os cortes foram imersos num meio contendo 3-3'diaminobenzidina (DAB-Sigma-Aldrich, Saint Louis, MO, EUA) $0,05 \%$ em tampão fosfato $0,1 \mathrm{M}$ por 5 minutos. Foram acrescentados a seguir $3 \mathrm{ml}$ de uma solução de $\mathrm{H}_{2} \mathrm{O}_{2}$ a $0,1 \%$ em água destilada, mantendo-se os cortes neste banho até que a reação fosse evidenciada. Atingida a imunorreatividade desejada com o desenvolvimento de coloração marrom, os cortes foram removidos da solução com DAB e imersas em tampão PB 0,1 M. Depois de nova série de lavagens em tampão fosfato 0,1 M com o objetivo de remoção do excesso de reagente, os cortes foram colocados sobre lâminas de vidro gelatinizadas e colocadas em placa quente, e após secarem foram hidratadas em água destilada por 1 minuto, banhadas em solução de tetróxido de ósmio 0,1\% por 15 - 30 segundos, desidratadas por uma série de álcoois em concentrações crescentes, clareadas com Hemo-De (Fisher) e cobertas com lamínulas, tendo como meio de montagem o Permount (Sigma). A imunorreatividade foi analisada em microscópio de luz e quantificações da marcação foram realizadas com o programa ImageJ $(\mathrm{NIH})$. Para análise semi-quantitativa capturamos imagens digitais em microscópio óptico (E1000, Nikon) acoplado a uma câmera digital e ao programa Nikon Imaging Software ACT-U. Obtivemos imagens da SNc e do CPu de diferentes níveis da estrutura de 5 animais de cada grupo. A análise da marcação na SNc foi realizada em um campo de $420.000 \mu \mathrm{m}^{2}$. Os dados foram obtidos através da utilização da ferramenta "Cell Counter", no programa Image 
J (NIH, USA), o que permitiu a quantificação do no de células TH-positivas. A análise foi feita no lado controle e experimental de cada corte, e com os valores obtidos realizou-se um cálculo da porcentagem de células TH-positivas no hemisfério experimental em relação ao controle tomado como 100\% (Figura 7). A análise de GFAP e OX42 foi feita na mesma área citada anteriormente, porém, analisou-se a densidade integrada da marcação obtida para estes anticorpos.

A análise no CPu foi feita através da quantificação da densidade integrada da marcação obtida em um campo de $2500 \mu \mathrm{m}^{2}$, também no Image J (NIH, USA). Os valores foram obtidos após realizarmos 3 medidas em regiões distintas do corte através do $\mathrm{CPu}$, e destas obteve-se uma média (Figura 8). As medidas foram repetidas em 5 cortes e destes valores fez-se uma média para cada animal. Com os valores das médias fez-se uma razão (média da densidade integrada do hemisfério experimental/ média da densidade integrada do hemisfério controle), e, assim, obteve-se um valor final para cada animal. Os dados foram então submetidos às análises estatísticas no programa Statistic11 (Statsoft, USA), e estão representados nos gráficos mostrados na seção de resultados na forma de médiaterro padrão da média (Graph Pad Prism 5, USA).

Figura 7 - Esquema llustrativo da SNc do encéfalo de ratos.

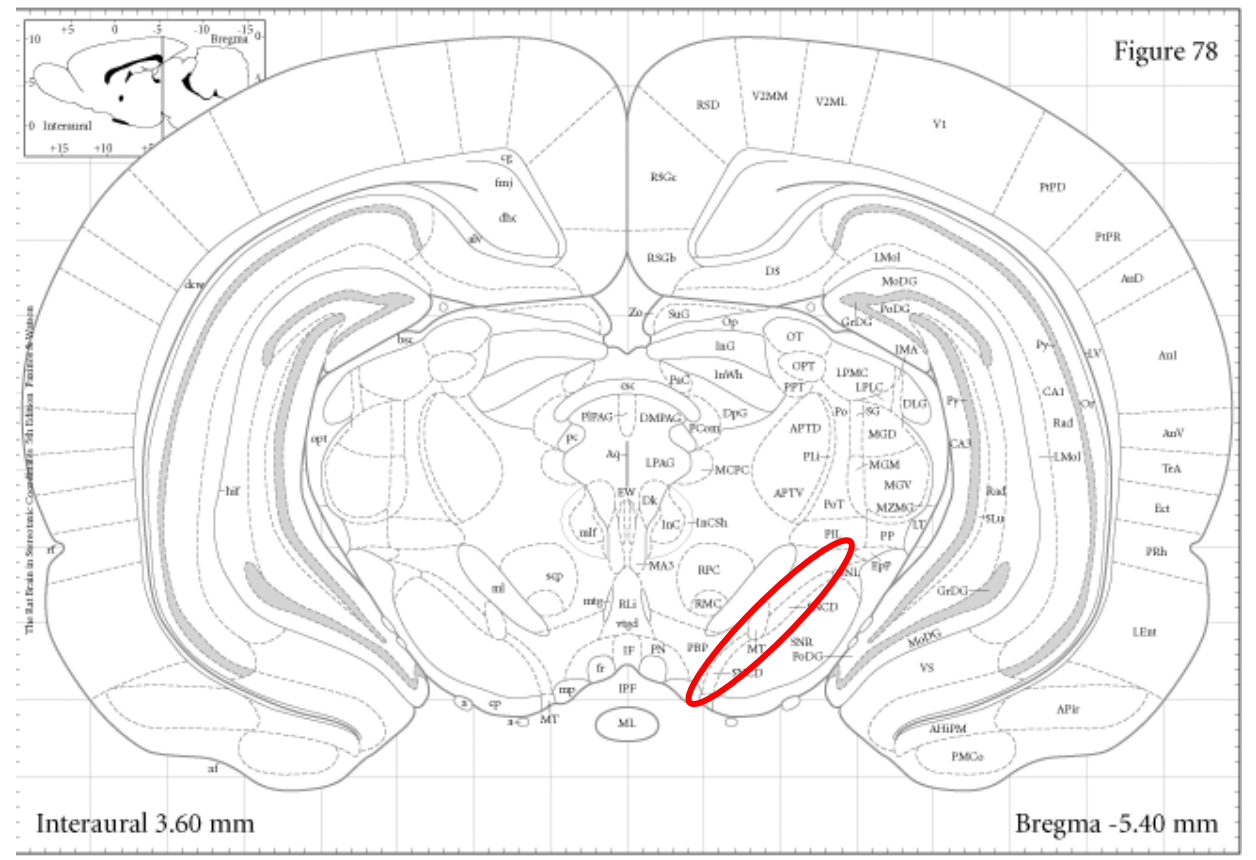

$\mathrm{Na}$ imagem destacamos, em vermelho, a região da SNc, área na qual se realizou a contagem de células TH-positivas.

Fonte: Adaptado de Paxinos e Watson (2005) 
Figura 8 - Esquema llustrativo do CPu do encéfalo de ratos.

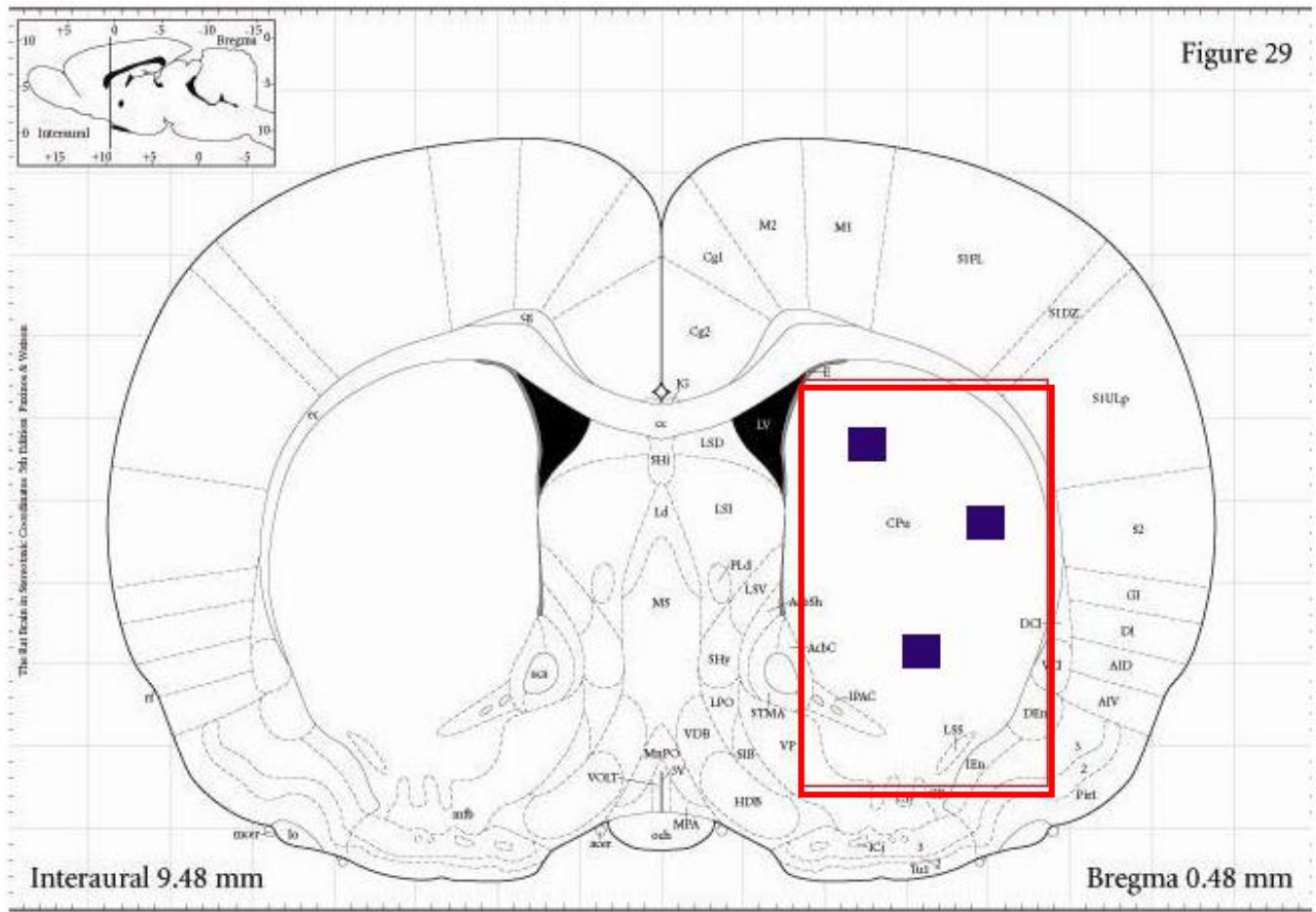

$\mathrm{Na}$ imagem destacamos, em vermelho, a representação da região do $\mathrm{CPu}$, e em azul, as regiões das áreas que analisou-se a densidade integrada da marcação para TH. Fonte: Adaptado de Paxinos e Watson (2005)

\subsubsection{Marcação retrógrada de neurônios da substância negra}

Esta técnica foi utilizada na padronização das injeções estereotáxicas, seguindo as coordenadas descritas acima (tópico 2.3). Injeções com $1 \mu$ l de solução aquosa $(0,9 \%$ de $\mathrm{NaCl})$ contendo FluoroGold (Traçador retrógrado fluorescente) (Sigma; St. Louis, MO) a $2 \%$ foram aplicadas no estriado com micropipetas através de pulsos de pressão (Liang et al., 2008). Após 7 dias o animal foi perfundido seguindo o mesmo protocolo da imuno-histoquímica. Os cortes contendo fluorogold foram colocados em lâminas gelatinizadas. Após estarem secas, foram cobertas com glicerol e tampão carbonato e lamínulas. Posteriormente, foram analisadas no microscópio de fluorescência. Obteve-se imagem apenas para ilustração da padronização da injeção. 


\subsubsection{Imunofluorescência}

Está técnica foi utilizada apenas no período de testes para verificar se as coordenadas onde foi injetado o fluoro-gold correspondiam com a localização de TH na SNc. Assim, os cortes de animais que receberam a injeção de fluoro-gold foram incubados com anticorpo contra TH feito em camundongo diluído em Triton X-100 a 0,3\% em PB, na concentração 1:1000, por no mínimo 14 horas. Após 3 lavagens (10 minutos cada) em PB, os cortes foram incubados por 2 horas com o anticorpo secundário marcado com os fluoróforos tetrametil isotiocianato de rodamina (TRITC) dirigido contra a lgG do animal onde o anticorpo primário foi produzido. A seguir, os cortes foram lavados 3 vezes em PB, colocadas em lâminas gelatinizadas e cobertos com glicerol e tampão carbonato e lamínulas. Após estarem secas, foram analisadas no microscópio para fluorescência. Obteve-se imagem apenas para ilustração e padronização da injeção.

\subsubsection{Fluoro Jade B}

O Fluoro Jade B é um modelo de fluorocromo que pode detectar degeneração neuronal. Há uma alta afinidade do traçador com processos neuronais em degeneração, incluindo corpo celular, dendritos, axônio e terminais axônicos (Schmued, Hopkins, 2000). Assim, os cortes da SNc e CPu obtidos no micrótomo foram selecionados e colocados em lâminas gelatinizadas e deixadas aproximadamente 24 horas em uma placa quente. As lâminas foram então colocadas em etanol absoluto por 3 minutos, seguido de etanol a $70^{\circ}$ por 1 minuto e água deionizada por 1 minuto. Posteriormente as lâminas foram imersas em uma solução de 0,06\% permanganato de potássio em água deionizada, por 15 minutos sob agitação. Após nova lavagem das lâminas em água deionizada por 1 minuto, estas foram incubadas na solução de 0,001\% de Fluoro-Jade B (Histochem; Jefferson, $\mathrm{AK}$ ) em água deionizada com $0,1 \%$ de ácido acético por 30 minutos sob agitação, no escuro. As lâminas foram lavadas três vezes em água deionizada e banhadas 2 vezes em xilol, por 1 minuto, sendo então cobertas com DPX (EMS; Fort Washington, PA) e lamínulas. As lâminas foram analisadas em microscópio de fluorescência. Imagens foram capturadas para ilustração. 


\subsubsection{Protocolo de immunoblotting}

Após o protocolo do estudo os animais ( $n=5 /$ grupo) foram guilhotinados, e o mesencéfalo e o $\mathrm{CPu}$ foram rapidamente coletados e homogeneizados a ${ }^{\stackrel{\circ}{ } \mathrm{C}} \mathrm{em}$ tampão de extração (Tris pH 7,4 100 mM; EDTA 10 mM; PMSF 2 mM; aprotinina $0,01 \mathrm{mg} / \mathrm{ml}$ ) com um homogenizador do tipo Turratec modelo MA-102/mini (Marconi; São Paulo, Brasil). Os homogenatos foram centrifugados a 12.000 rpm por 20 minutos a $4^{\circ} \mathrm{C}$ em uma centrífuga modelo CT14000 DR (Cientec, São Paulo, Brasil). O conteúdo protéico do material isolado dos diferentes grupos foi dosado pelo método de Bradford (Amresco, U.S.A)(Bradford, 1976). As amostras contendo as proteínas foram armazenadas em freezer $-70^{\circ} \mathrm{C}$ com tampão Laemmli (Tris/HCl 125 $\mathrm{mM}, \mathrm{pH}$ 6,8, contendo 2,5\% (p/v) de SDS, 2,5\% de 2-mercaptoetanol (2-ME), 4mM de EDTA e 0,05\% de azul de bromofenol) (Laemmli, 1970), contendo DTT $100 \mathrm{mM}$. Estas amostras foram submetidas à eletroforese em géis de acrilamida a 6,5\% [para óxido nítrico sintetase induzível (iNOS - 160KDa) - Santa Cruz Biotechnology, INC. SC-650; e $\beta$-actina (Sigma, A53160)]; 10\% (para TH - 52KDa, GFAP - 51KDa e $\beta$ actina - 42KDa), e 15\% [para fator neurotrófico derivado do encéfalo, feito em coelho (BDNF - Chemicon - Millipore, AB1779SP - 14KDa); e $\beta$-actina], contendo dodecil sulfato de sódio utilizando uma cuba para mini-gel (Mini-Protean 3; Bio-Rad). Após a separação eletroforética, as proteínas foram eletro-transferidas para uma membrana de nitrocelulose utilizando-se um sistema de transferência (Trans-Blot cell system; Bio-Rad), em tampão contendo SDS, de acordo com a técnica descrita por Towbin e colaboradores (1979). Após a transferência, as membranas foram incubadas em solução de bloqueio com leite desnatado (Molico, Nestlé) a $5 \%$ em tampão salina contendo Tween 20 (TTBS; 0,01 M de Tris- $\mathrm{HCl}, \mathrm{PH} 7,4,0,15 \mathrm{M}$ de $\mathrm{NaCl}, 0,05 \%$ de Tween 20), por 2 horas em temperatura ambiente sob agitação leve, exceto para BDNF que foi incubada overnight em geladeira. Após este período, as membranas foram lavadas por três vezes de 10 minutos com TTBS e incubadas com os anticorpos primários na concentração de 1:1000 (TH, GFAP, iNOS), 1:250 (BDNF) e $\beta$-actina, na concentração 1:10000, em solução bloqueadora de albumina, por 18 horas a $4{ }^{\circ} \mathrm{C}$, sob leve agitação. Em seguida, as membranas foram lavadas novamente e incubadas por 2 horas com um anticorpo secundário conjugado com peroxidase (anti-coelho para o BDNF e anti-camundongo para TH, GFAP, iNOS e $\beta$ - 
actina) (Amersham; Little Chalfont, Buckinghamshire, UK) em temperatura ambiente, diluído a 1:10000 em solução bloqueadora, contendo 1\% de leite desnatado em TTBS. Novo ciclo de lavagens da membrana foi realizado e a ligação específica do anticorpo com a proteína foi revelada utilizando o kit quimioluminescente ECL (Amersham Biosciences, NJ, EUA). Finalmente as bandas obtidas nos filmes foram escaneadas e analisadas quanto à densidade óptica da imunorreatividade usandose o programa Scion Image (Scion Corporation, Frederick, MD, EUA). Dos dados obtidos realizou-se uma razão entre a densidade óptica da marcação para $\mathrm{TH}$, GFAP, iNOS e BDNF com a da $\beta$-actina. Os dados foram normalizados pelo grupo controle e submetidos às análises estatísticas no programa Statistica 11 e os dados representados pelo programa Graph Pad Prisma5.

\subsubsection{Análise da fluorescência derivada dos produtos de oxidação da dihidroetidina (DHE) em cortes histológicos}

A DHE é um marcador que ao ser oxidado por superóxido intracelular (marcador de estresse oxidativo) se liga ao DNA da célula e emite uma fluorescência vermelha nuclear, sendo um excelente marcador de estresse oxidativo.

Para análise dos níveis de EROs intracelulares, utilizamos uma técnica já utilizada anteriormente em nosso laboratório (Hernandes et al., 2010; Pestana et al., 2010). Para isto, 3 animais por grupo foram sacrificados por decapitação, e seus encéfalos foram imersos em meio para congelamento (Leica Instruments), e congelados em gelo seco. Foram feitos cortes transversais de $18 \mu \mathrm{m}$ em criostato da SNc e CPu, que foram colocados em lâminas gelatinizadas. Os cortes do tecido foram incubados com tampão fosfato (PB) contendo 0 ácido dietilenotriaminopentaacético (DTPA) (100 $\mu \mathrm{M})$ por $10 \mathrm{~min}$ e incubadas com dihidroetidina $(5 \mu \mathrm{M})$ diluída em PB contendo DTPA $100 \mu \mathrm{M}$, em câmara úmida (5 minutos, a $37^{\circ} \mathrm{C}$ ), protegida de luz. A fluorescência dos cortes foi detectada em microscópio óptico Nikon com filtro para rodamina, com objetiva de 10x. Imagens digitais das áreas de interesse foram obtidas por meio de uma câmera de vídeo acoplada ao microscópio. Os parâmetros utilizados para capturar as imagens digitais foram mantidos absolutamente constantes. Realizou-se a captura de imagens de 5 cortes de cada animal, do hemisfério controle e experimental, representando uma área de $0,54 \mathrm{~mm}^{2}$. Os dados foram analisados com auxílio do programa Image J® 
4.37 (Wayne Rasband, National Institutes of Health/USA), onde utilizamos a ferramenta "analyze particles" (size: 100-1000 pixels). A análise foi feita no lado controle e experimental de cada corte, e com os valores obtidos realizou-se um cálculo da porcentagem de células DHE-positivas no hemisfério experimental em relação ao controle tomado como $100 \%$. Os dados foram normalizados pelo grupo controle (SED) e submetidos às análises estatísticas no programa Statistica 11 e os dados representados pelo programa Graph Pad Prisma5.

\subsubsection{Avaliação da expressão de BDNF por ELISA}

Esta quantificação foi realizada através do Kit ELISA - BDNF Emax® ImmunoAssay System (Promega), de acordo com as recomendações do fabricante, como descrito em um trabalho do departamento (Rueda et al., 2011).

Os animais submetidos aos protocolos de interesse $(n=3)$ foram guilhotinados e as amostras foram coletadas (mesencéfalo e o $\mathrm{CPu}$ ) e rapidamente congeladas em nitrogênio líquido, e posteriormente mantidas a $-80^{\circ} \mathrm{C}$.

O protocolo de extração de proteínas utilizou o tampão lise recomendado pelas especificações do Kit, ou seja, (137 mM NaCl; $20 \mathrm{mM}$ Tris- $\mathrm{HCl}$ (pH 8.0); 1\% Triton X-100; 10\% glicerol; $1 \mathrm{mM} \mathrm{PMSF;} 10 \mu \mathrm{g} / \mathrm{ml}$ aprotinina; $1 \mu \mathrm{g} / \mathrm{ml}$ leupeptina; 0.5 $\mathrm{mM}$ ortovanadato de sódio). Adicionou-se às amostras $300 \mu \mathrm{l}$ do tampão lise, em seguida as amostras foram sonicadas e posteriormente centrifugadas a $12000 \mathrm{rpm}$ por 20 minutos a $4 \stackrel{\circ}{\circ}$. $O$ sobrenadante foi estocado a $-80^{\circ} \mathrm{C}$ até a realização do ELISA.

Para detecção da expressão de BDNF, inicialmente cada poço de uma microplaca de ELISA foi coberto com $100 \mu$ de anticorpo monoclonal anti-BDNF diluído 1:1000 em tampão carbonato (25 mM NaHCO $3,25 \mathrm{mM} \mathrm{Na}_{2} \mathrm{CO}_{3}, \mathrm{pH}$ 9,7). A placa foi selada e incubada overnight a $4 \stackrel{\circ}{\mathrm{C}}$. Lavou-se a placa com tampão de lavagem TBST (20 mM Tris- $\mathrm{HCl}$ pH 7,6, $150 \mathrm{mM} \mathrm{NaCl}, 0,05 \%$ Tween®20) e a seguir a placa foi selada e incubada por 1 hora à temperatura ambiente com $200 \mu \mathrm{l} /$ poço de tampão de bloqueio. Lavou-se a placa três vezes e ela foi incubada por 2 horas à temperatura ambiente sob agitação (cerca de $400 \mathrm{rpm}$ ) com $100 \mu \mathrm{l} /$ poço das amostras ou com a curva padrão fornecida pelo kit (BDNF diluído 1:2000 em tampão de bloqueio e diluições seriadas 1:2 a partir desta concentração inicial, variando de 
$500 \mathrm{pg} / \mathrm{ml}$ a 0). Após este passo, a placa foi lavada cinco vezes, e incubou-se cada poço com $100 \mu \mathrm{l}$ de anticorpo policlonal para BDNF diluído 1:500 em tampão de bloqueio por 2 horas à temperatura ambiente, sob agitação.

Novamente, a placa foi lavada cinco vezes, e seguiu-se a incubação com anticorpo secundário anti-IgY conjugado à enzima HRP (horseradish peroxidase) diluído 1:200 em tampão de bloqueio (100 $\mu /$ poço) por um período de 1hora, à temperatura ambiente, sob agitação. Ao término desta incubação, a placa foi lavada mais cinco vezes e adicionou-se a cada poço $100 \mu \mathrm{l}$ da solução TMB One (tetrametilbenzidina), que é o substrato da enzima HRP. A placa foi incubada por 10 minutos à temperatura ambiente sob agitação, e uma coloração azul foi formada. Ao final desta etapa, a reação foi terminada adicionando-se $100 \mu \mathrm{l}$ de $\mathrm{HCl} 1 \mathrm{~N}$ a cada poço, na mesma ordem que o substrato foi adicionado, mudando a coloração de azul para amarelo. A leitura espectrofotométrica foi realizada a um comprimento de onda de $450 \mathrm{~nm}$. Os dados foram submetidos à análise estatística no programa Statistica11 e representados em gráficos pelo programa Graph Pad Prisma5.

\subsection{Análise Estatística}

Os dados do estudo apresentaram uma distribuição normal segundo o teste de Kolmogorov-Smirnov. As análises dos dados foram conduzidas a partir do teste Two-way ANOVA para medidas não-repetidas, quando houve dois fatores de interferência (exercício e a injeção de K252a) e one-way quando a análise envolvia apenas o fator exercício. Quando a análise de variância apresentou diferença estatisticamente significante os dados foram submetidos ao pós-teste de Tukey. Para todos os testes, o nível de significância assumido foi de $p \leq 0,05$. Os resultados estão representados nos gráficos e descritos no texto na forma de médiaterro padrão da média. 


\section{CAPÍTULO 3 - CARACTERIZAÇÃO DO MODELO DA DOENÇA DE PARKINSON}

Antes de iniciarmos os experimentos com os diferentes protocolos do estudo propriamente dito, realizamos alguns testes, descritos a seguir, para a padronização do modelo em nosso grupo de estudo. O primeiro teste realizado foi para verificar se as coordenadas selecionadas no estereotáxico estavam corretas, e atingindo as estruturas desejadas. Para isto, injetamos nas coordenadas pré-definidas FluoroGold (um marcador retrógrado fluorescente), e associamos a marcação para TH com a técnica de imuno-fluorescência. Desta forma, podemos notar na figura 9 que os locais escolhidos para a injeção no CPu foram capazes de atingir a SN, pois notamos a presença de células marcadas tanto com Fluoro-Gold quanto com $\mathrm{TH}$.

Figura 9 - Imagem digital de corte coronal de encéfalo de rato ilustrando a dupla marcação para Fluoro-Gold (azul) e TH (vermelho) na SNc.

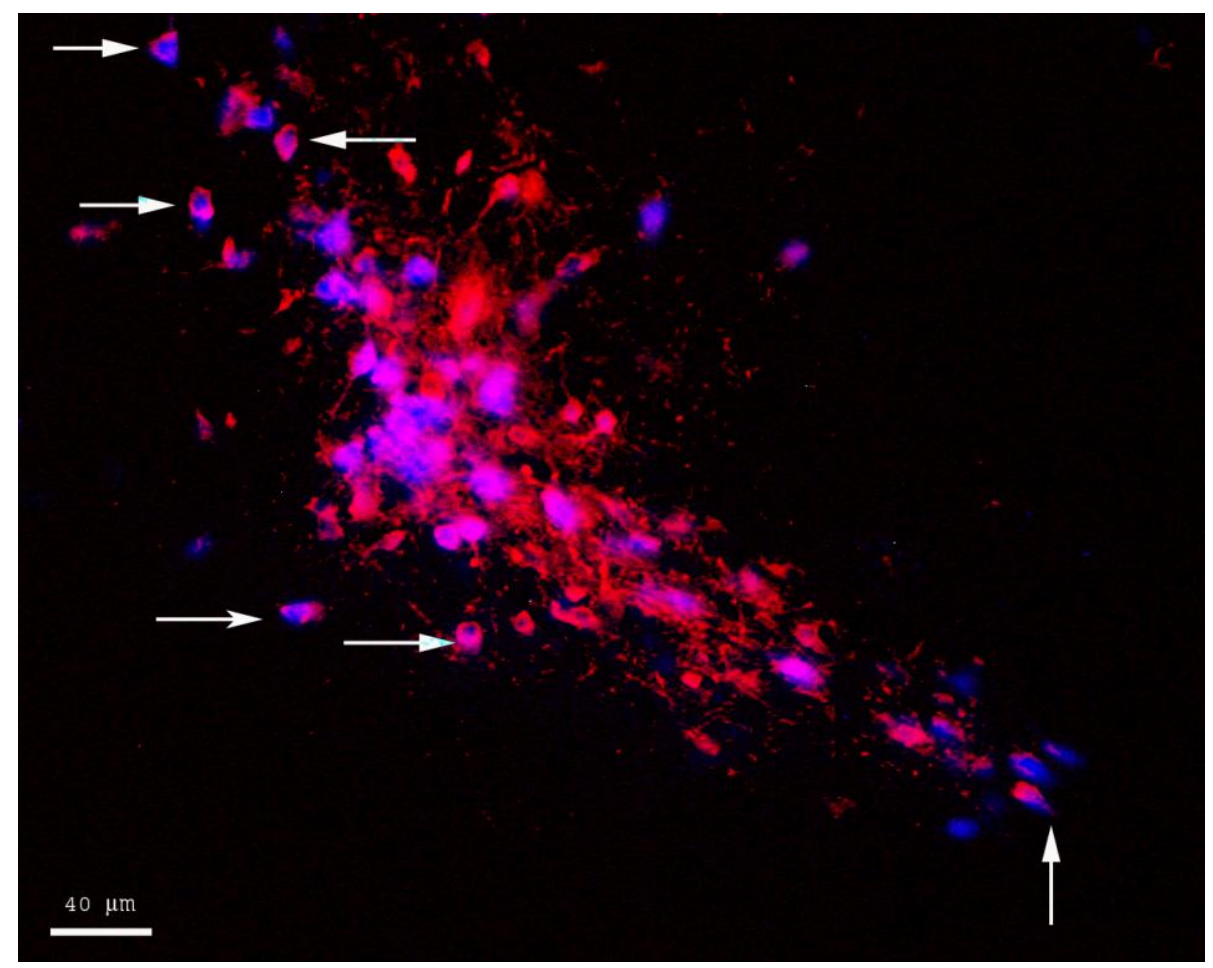

As setas indicam alguns exemplos de marcações duplas na SNc após 7 dias da injeção de Fluoro-Gold em duas coordenadas distintas no CPu. 
Após a padronização das coordenadas, iniciamos os testes com 3 diferentes concentrações da 6-OHDA, sendo elas $6 \mu \mathrm{g}, 12 \mu \mathrm{g}$ e $24 \mu \mathrm{g}$. Notamos que com a injeção de $6 \mu \mathrm{g}$ da droga já há diminuição da expressão de TH tanto em número de células quanto em arborização dendrítica. A queda da expressão é intensificada conforme há o aumento da concentração da neurotoxina, sendo mais acentuada com $24 \mu \mathrm{g}$ da neurotoxina (Figura 10). Como o nosso objetivo foi analisar possível efeito neuroprotetor do exercício optamos por uma morte neuronal menos severa, ou seja, $6 \mu \mathrm{g}$.

Figura 10 - Imagens digitais de cortes coronais da SNc de rato ilustrando a expressão de TH na SNc após diferentes doses de injeção intraestriatal unilateral de 6-OHDA.



A figura ilustra a expressão de TH na SNc de animais após 16 dias da indução de DP por injeção intraestriatal unilateral de 6,12 ou $24 \mu \mathrm{g}$ de 6-OHDA. Notar a diminuição gradual de células marcadas com TH no lado experimental conforme aumenta-se a dose. 
Definido o local e a dose da neurotoxina a ser injetada analisamos a presença de degeneração celular. Para isto, utilizamos a técnica de Fluoro Jade B. Através desta técnica fomos capazes de notar que a aplicação de $6 \mu \mathrm{g}$ de 6-OHDA foi capaz de gerar processos em degeneração tanto no CPu quanto na SN após 7 dias da aplicação de 6-OHDA (Figura 11). Analisamos também a ativação de processo neuroinflamatório através da análise da proliferação microglial. Para isto, analisamos a expressão de OX42 (marcador de microglia) pela técnica de imuno-histoquímica (Figura 12). Logo, os procedimentos adotados na cirurgia foram capazes de gerar os mecanismos desejados e esperados no modelo da DP com 6-OHDA.

Figura 11 - Imagens digitais de cortes coronais de encéfalo de rato ilustrando a histoquímica para Fluoro-Jade B no CPu e SNc após a indução da DP por injeção intraestriatal unilateral de 6-OHDA.

\section{FLUORO JADE B}

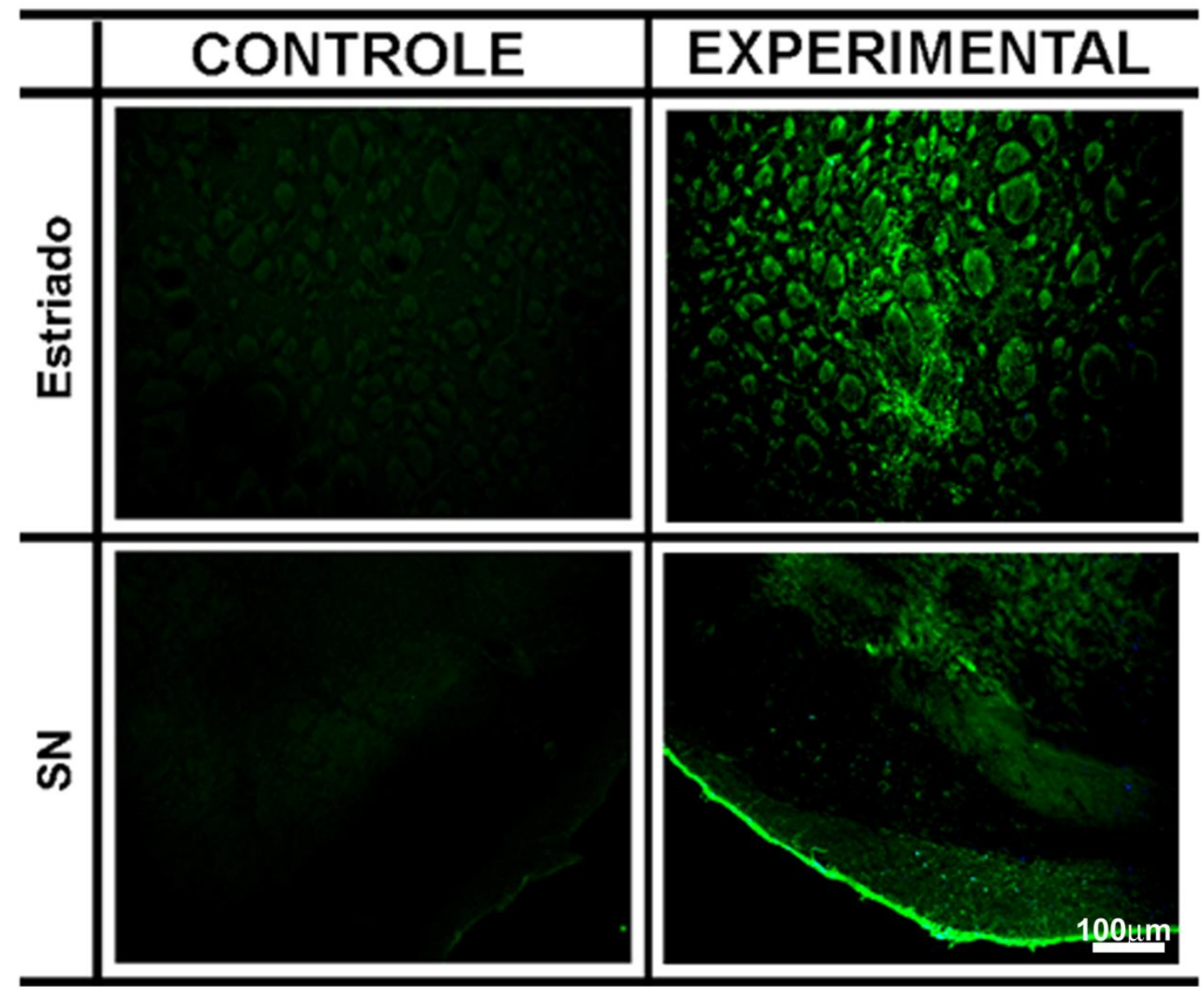

A marcação no lado experimental ilustra processos de degeneração após 7 dias da injeção da neurotoxina. 
Figura 12 - Imagens digitais de cortes coronais da SNc de rato ilustrando a imunohistoquímica para OX42 na SNc após a indução da DP por injeção intraestriatal unilateral de 6-OHDA.

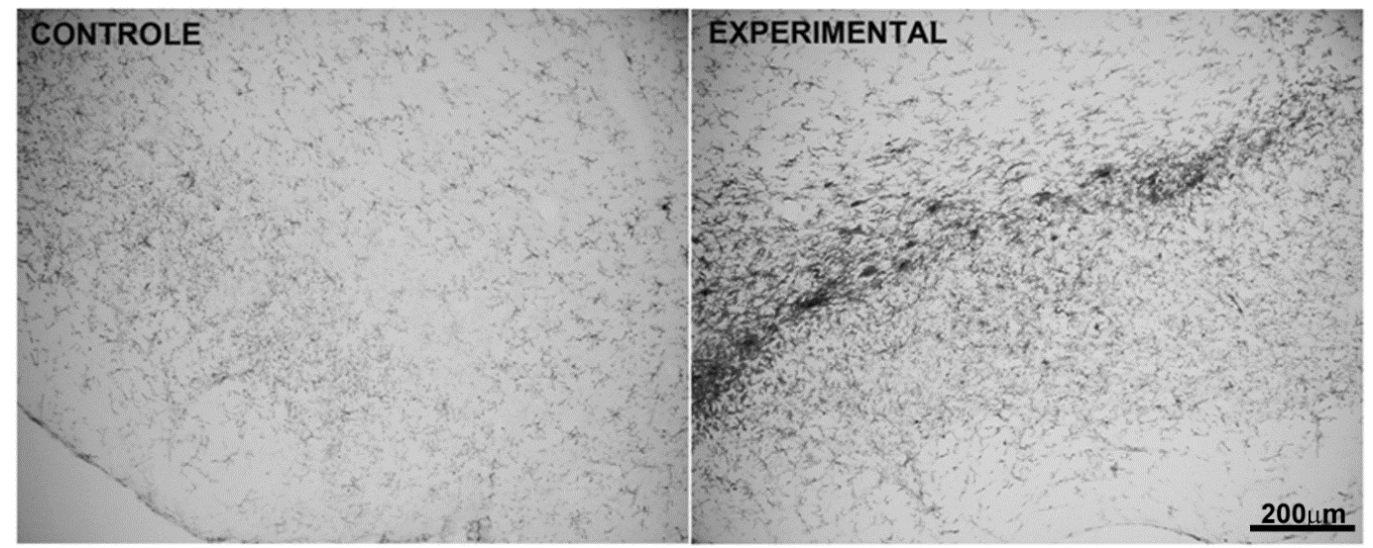

A imagem ilustra a imuno-histoquímica para OX42 na SNc de animais submetidos à indução da DP por injeção intraestriatal unilateral de 6-OHDA. Nota-se que há uma maior proliferação microglial no hemisfério experimental após 16 dias da injeção da neurotoxina.

A segunda fase de teste envolveu analisar se as microesferas carregadas com K252a (bloqueador de receptores de BDNF, TrkB) chegavam na SNc. Para isto, injetamos nas mesmas coordenadas anteriores (tópico 2.3) as microesferas, e sacrificamos o animal após 3 dias. Na Figura 13, podemos notar que as microesferas aplicadas no CPu foram transportadas até a SNc. Note que com 3 dias as microesferas encontram-se em toda a SNc, garantindo o acesso a esta região do inibidor K252a, que está ligado às microesferas.

Figura 13 - Imagem digital de corte coronal de encéfalo de rato ilustrando a presença de microesferas no CPu e na SNc.
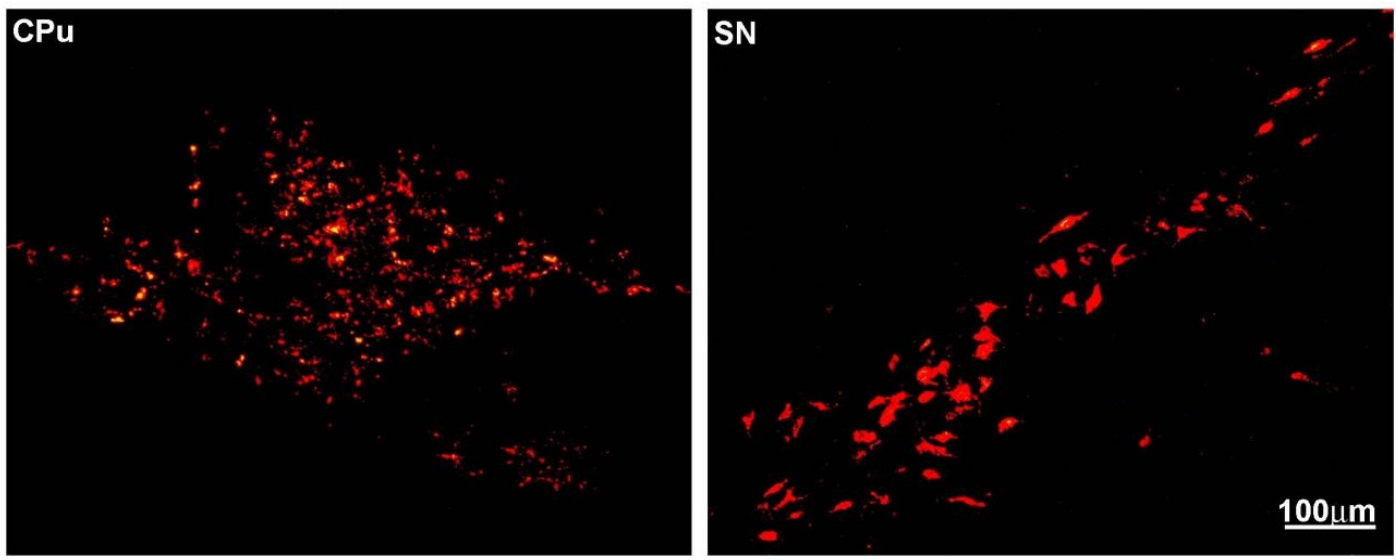

Note que após 3 dias da injeção das microesferas, em duas coordenadas distintas no CPu, elas já foram transportadas até a SNc, e consequentemente o inibidor K252a já estaria disponível para atuar nos eurônios dopaminérgicos. 


\section{CAPÍTULO 4 - O PAPEL DO BDNF NOS EFEITOS PROMOVIDOS PELO EXERCÍCIO}

Os dados apresentados neste capítulo foram publicados recentemente no periódico Neuroscience [237 (2013) 118-129] (apêndice A).

\subsection{Desenho experimental}

Nesta fase do projeto analisamos o envolvimento do BDNF nos efeitos promovidos pelo exercício, para isto, dividimos o nosso estudo em dois grandes grupos de animais: (1) aqueles que receberam a injeção intraestriatal de K252a (o inibidor de TrkB) com o objetivo de bloquear as ações do BDNF (Kafitz et al., 1999); (2) aqueles que não receberam o bloqueador do receptor de BDNF. Estes grupos, foram então, subdivididos em 4 sub-grupos, totalizando 8 sub-grupos. Cada um deles foi composto por 10 animais ( 5 animais para a técnica de imuno-histoquímica e 5 para a técnica de immunoblotting).

(1) animais que receberam a injeção intraestriatal de salina e não foram submetidos ao exercício em esteira, sendo o grupo designado como controle (CLT e CLT+K252a). Este grupo representa os dados de animais Sham (Yoon et al., 2007);

(2) animais que receberam a injeção intraestriatal de 6-OHDA e não foram submetidos ao exercício em esteira, designados como sedentários (SED e SED+K252a);

(3) animais que receberam a injeção intraestriatal de 6-OHDA e foram submetidos ao exercício em esteira 3 vezes por semana, durante 4 semanas antes e 4 semanas depois da indução da DP, e designados como EXA+EXD e $E X A+E X D+K 252 a$;

(4) animais que receberam a injeção intraestriatal de 6-OHDA e foram submetidos ao exercício em esteira 3 vezes por semana, apenas 4 semanas após a indução da DP, e designados como EXD e EXD+K252a.

Com 2 meses de idade os animais do grupo EXA+EXD iniciaram o protocolo de exercício; com 3 meses de idade os animais receberam as injeções intraestriatais (6-OHDA, salina e K252a), e o grupo EXD iniciou o protocolo de exercício (2 dias após a cirurgia); e com 4 meses de idade os animais foram submetidos aos testes comportamentais (CA e teste rotacional), e em seguida eutanasiados. As estruturas 
de interesse foram coletadas e submetidas às técnicas de imuno-histoquímica e immunoblotting para análise da expressão de TH e BDNF. A figura 14 resume as etapas do protocolo.

Figura 14 - Desenho experimental.

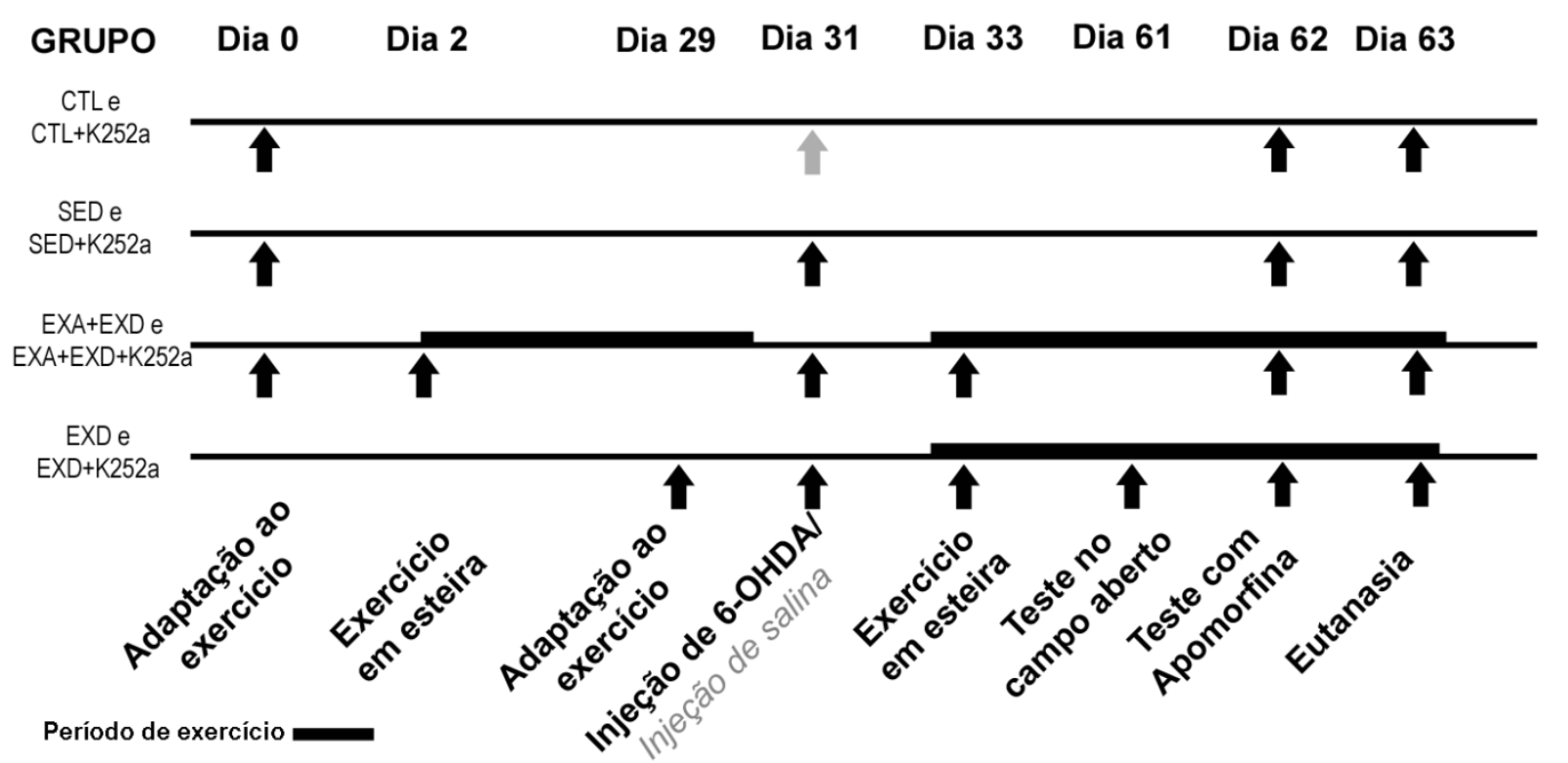

Os ratos exercitados foram submetidos ao protocolo de exercício em esteira (3x/semana, 40 minutos). Controle (CLT; CLT+K252a); sedentários (SED; SED+K252a); exercitados por 4 semanas antes e 4 semanas depois da indução da DP (EXA+EXD; EXA+EXD+K252a); exercitados por 4 semanas depois da indução da DP (EXD; EXD+K252a). Os grupos nomeados como CLT+K252a, SED+K252a, EXA+EXD+K252a, e EXD+K252a receberam o bloqueador do receptor de BDNF (K252a) juntamente com a injeção de 6-OHDA ou salina. Após a avaliação comportamental, todos os ratos foram eutanasiados e as estruturas de interesse analisadas pelas técnicas de immunoblotting ou imuno-histoquímica.

Os dados das técnicas utilizadas nos diferentes grupos revelam, de modo geral, que o protocolo de exercício em esteira foi capaz de promover mudanças benéficas na SNc e no CPu. Por outro lado, a adição de K252a promoveu respostas distintas às encontradas no grupo onde não houve bloqueio dos receptores de BDNF. Além disso, a análise comportamental também demonstrou uma piora nos animais do grupo K252a. Assim, segue a descrição dos dados obtidos nos diferentes grupos, sendo eles divididos em três tópicos: testes comportamentais, BDNF e TH. 


\subsection{Resultados}

\subsubsection{Testes Comportamentais}

\subsubsection{Campo aberto}

Os resultados obtidos no campo aberto (CA) (n=10/grupo) 7 dias após o procedimento cirúrgico demonstraram, de modo geral, que não houve mudanças na frequência locomotora dos animais que receberam ou não o bloqueador K252a $[F(3,72)=3,2673 ; p=0,02612]$, exceto o grupo EXD+K252a que apresentou uma diminuição na frequência de locomoção se comparado ao mesmo grupo que não recebeu K252a (ca. 22\%; p=0,006176) (Figura 15A). Por outro lado, após 28 dias, os animais do grupo SED apresentaram um aumento na frequência de locomoção de aproximadamente 50\%, se comparados ao grupo CLT ( $\mathrm{p}=0,000831)$ e exercitados ( $E X A+E X D ; p=0,00249 ; E X D ; p=0,001338$ ). A adição de K252a manteve a frequência de locomoção aumentada no grupo SED+K252a quando comparado ao grupo CLT+K252 (ca. 46\%; $p=0,001378$ ), e não alterou a frequência dos grupos exercitados (EXA+EXD+K252a; EXD+K252a) $[F(3,72)=14,002 ; p=0,000001]$ (Figura 15B).

Assim, notamos que houve uma diferença entre as frequências de locomoção da primeira e da segunda exposição apenas nos grupos que não receberam K252a $[F(3,72)=10,970 ; p=0,000001]$, sendo eles CLT (ca. 33\%; $p=0,000364$ ), EXA+EXD (ca. 35\%; $p=0,000136$ ), e EXD (ca. 38\%; $p=0,000124$ ). Por outro lado, o grupo SED e todos que receberam K252a (CLT+K252a; SED+K252a; EXA+EXD+K252a; EXD+K252a) mantiveram frequência de locomoção semelhantes na primeira e segunda exposição $[F(3,72)=2,7201 ; p=0,05072]$ (Figuras 16A e 16B) (Tabela 1 apêndice B) 
Figura 15 - Análise da frequência de locomoção de ratos expostos por 5 minutos no campo aberto.
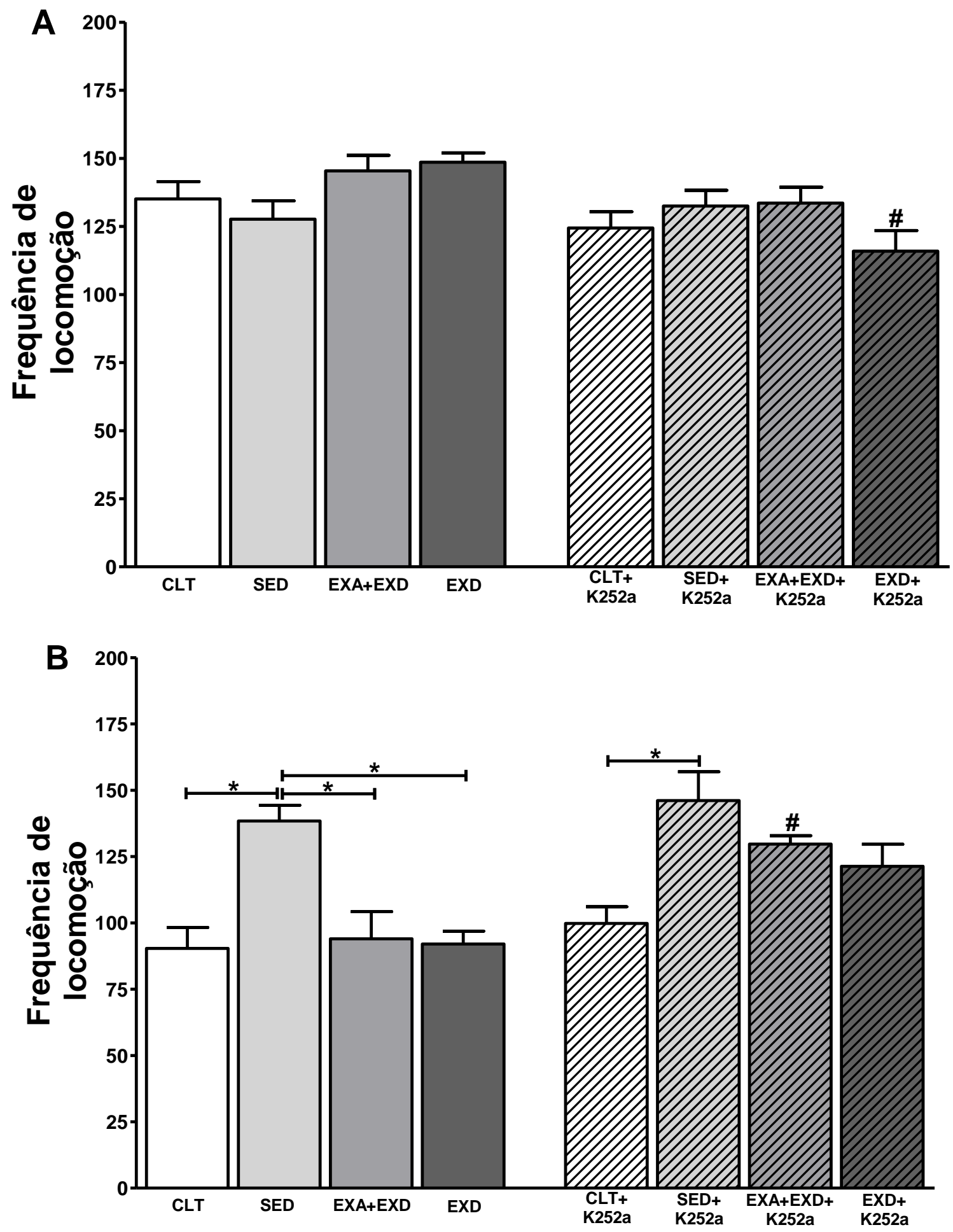

A- comparação entre os grupos de animais 7 dias após a injeção de 6-OHDA. Bcomparação entre os grupos de animais 28 após a injeção de 6-OHDA. (CLT - SAL, sedentário - SED, treinados por 4 semanas antes e 4 semanas depois da cirurgia $E X A+E X D$, treinados 4 semanas após a cirurgia - EXD). * $p<0.05$. \# indica significância entre o grupo que recebeu $\mathrm{K} 252 \mathrm{a}$ e seu correspondente que não recebeu a droga bloqueadora do receptor de BDNF. 
Figura 16- Análise da frequência de locomoção de ratos expostos por 5 minutos no campo aberto.


A- comparação entre os grupos de animais que não receberam o bloquear K252a, 7 e 28 dias após a injeção de 6-OHDA. B- comparação entre os grupos de animais que receberam o bloquear K252a, 7 e 28 dias após a injeção de 6-OHDA. * $p<0.05$; \# representa diferença estatisticamente significante entre a primeira (7 dias) e a segunda exposição (28 dias) ao CA entre animais do mesmo grupo. 


\subsubsection{Teste de Rotação}

Um mês após a injeção de 6-OHDA ( $n=10 /$ grupo), o outro teste comportamental realizado foi o teste rotacional induzido por apomorfina. Os dados, de modo geral, revelaram mudanças no comportamento rotacional dos animais $[F(3,72)=17,577 ; \quad p=0,000001]$. Não observamos comportamento rotacional assimétrico nos grupos controles (CLT e CLT+K252a) e nem nos grupos exercitados (EXA+EXD e EXD). Por outro lado, os grupos sedentários e exercitados tratados com K252a (EXA+EXD+K252a e EXD+K252a) apresentaram um aumento, por volta de $1000 \%$, na assimetria rotacional induzida por apomorfina se comparados aos grupos CLT (SED; SED+K252a; EXA+EXD+K252a; EXD+K252a; $p=0,000123$ ) (Figura 17) (Tabela 1 - apêndice B)

Figura 17 - Efeitos do treino em esteira e do bloqueio do receptor de BDNF sobre o comportamento rotacional induzido por apomorfina em ratos.

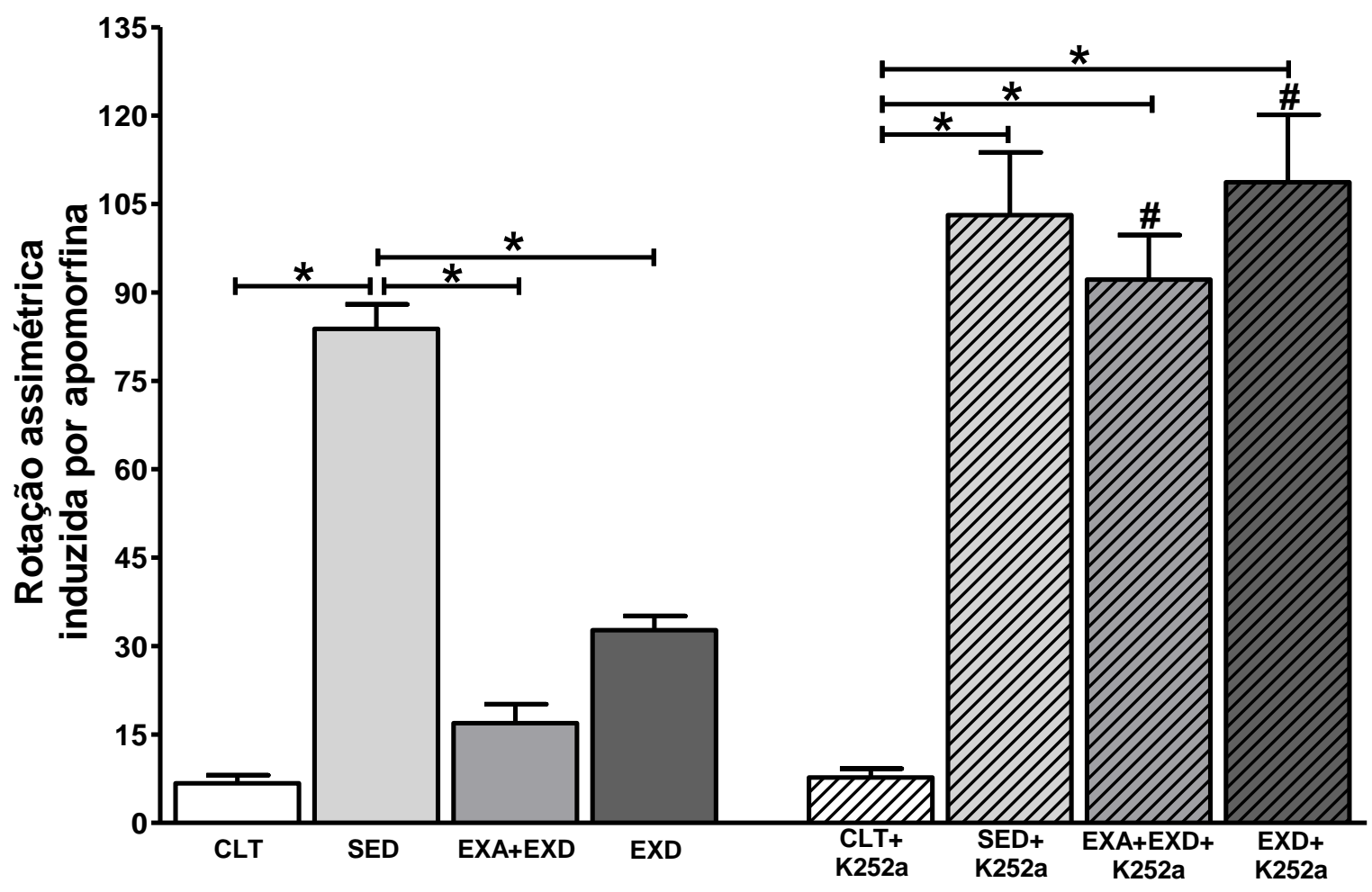

O gráfico representa a média da rotação assimétrica de cada grupo. Note que o exercício diminui a disfunção comportamental. E o bloqueio do receptor de BDNF, K252a, reverte a melhora comportamental. " $p<0.05$. \# indica significância entre o grupo que recebeu K252a e seu correspondente que não recebeu a droga bloqueadora do receptor de BDNF.

Fonte: Modificado de Real et al., 2013. 


\subsubsection{BDNF}

Os dados de immunoblotting ( $n=5 /$ grupo) revelaram que os níveis relativos de BDNF diminuíram apenas na SNc do grupo SED quando comparados ao grupos CLT (ca.57\%; p=0,0002) e exercitados (EXA+EXD - ca. 88\%; EXD - ca. 52\%; $p=0,001)[F(3,32)=22,284 ; p=0,0000001]$. Um resultado similar foi observado após o tratamento com K252a no grupo SED+K252a em relação aos outros grupos (CLT+K252a - ca. 41\%; p=0,008; EXA+EXD+K252a - ca. 37\%; p=0,03; EXD+K252a - ca. 43\%; $p=0,03$ ) (Figura 18), logo, não houve mudanças na expressão de BDNF na SNc após a adição do bloqueador K252a $[F(1,32)=0,206 ; p=0,65]$. Por outro lado, os níveis no $\mathrm{CPu}$ não sofreram mudanças significativas em momento algum do estudo $[F(3,32)=0,65970 ; p=0,58]$ (Figura 19) (Tabela 2 - apêndice B).

Figura 18 - Efeitos do exercício em esteira e do bloqueio do receptor de BDNF sobre os níveis de BDNF na SNc.



As barras representam a razão da densidade óptica entre BDNF e beta-actina, comprando os hemisférios experimentais de cada grupo. A imagem representa bandas típicas de immunoblots para cada condição experimental. Note que os níveis de BDNF na SNc diminui nos ratos sedentários, e não se altera após o bloqueio de receptores de BDNF. ${ }^{*} p<0.05$.

Fonte: Modificado de Real et al., 2013. 
Figura 19 - Efeitos do exercício em esteira e do bloqueio do receptor de BDNF sobre os níveis de BDNF no CPu.

\section{BDNF \\ 14KDa \\ $\beta$-actina}

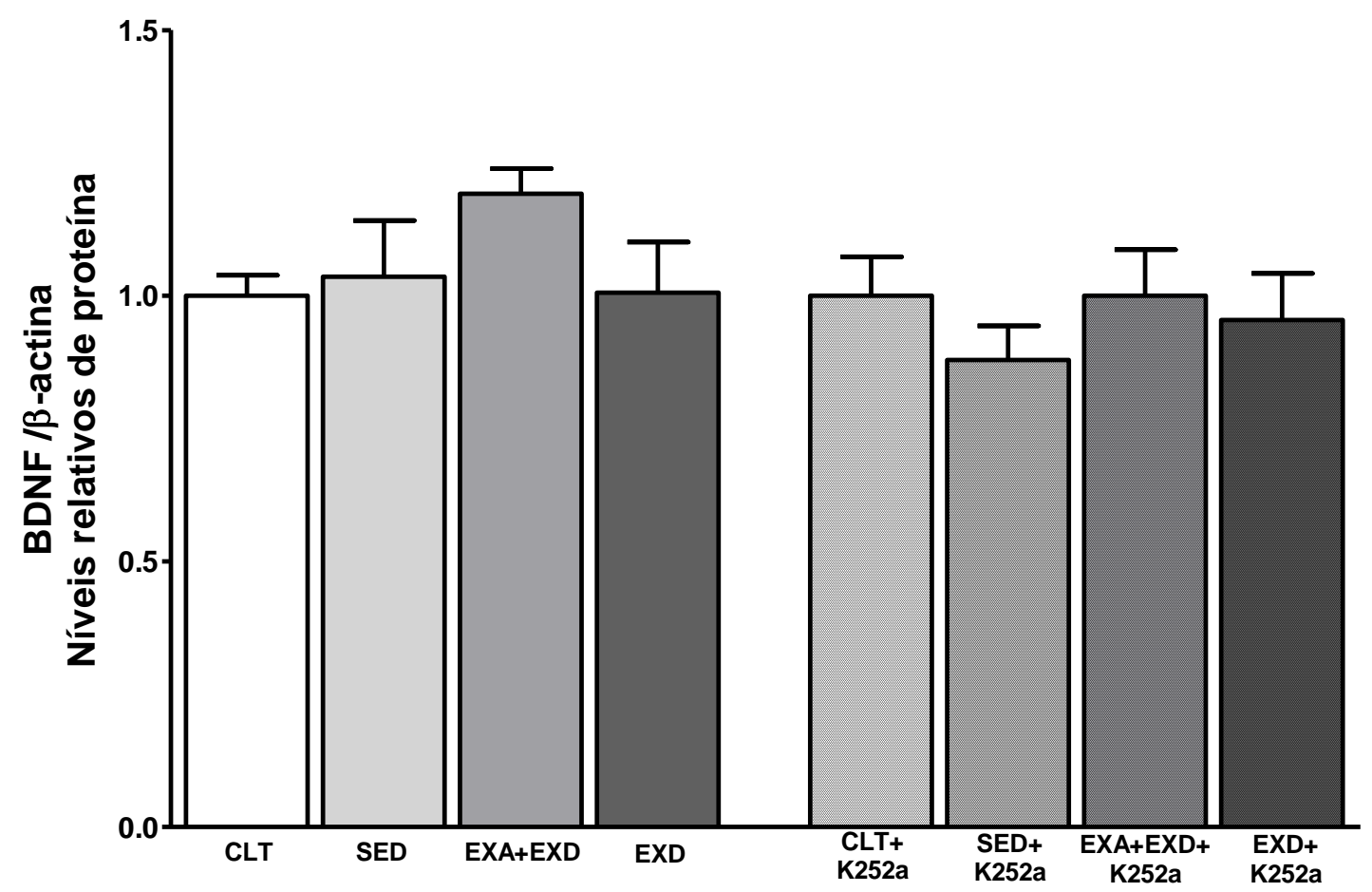

As barras representam a razão da densidade óptica entre BDNF e beta-actina, comprando os hemisférios experimentais de cada grupo. A imagem representa bandas típicas de immunoblots para cada condição experimental. Note que os níveis de BDNF no CPu não se alteram após a injeção de 6-OHDA e do bloqueador de receptores de BDNF.

Fonte: Modificado de Real et al., 2013. 


\subsubsection{TH}

As análises obtidas na imuno-histoquímica ( $n=5 / g r u p o)$ referem-se à expressão de TH na SNc e no CPu nos oito grupos analisados. A marcação para TH na SNc está presente em corpos celulares e arborizações dendríticas de todos os grupos estudados, como podemos observar na Figura 20. Já a marcação no CPu está presente, em toda a estrutura, em terminações nervosas de células dopaminérgicas provenientes da SNc (Figura 23). O grupo CLT não apresentou diferença na marcação para $\mathrm{TH}$, enquanto os grupos que receberam 6-OHDA apresentaram respostas distintas. Os resultados, em sua grande maioria, revelaram déficits de $\mathrm{TH}$ em ambas as estruturas dos animais sedentários e em animais treinados que receberam o bloqueador K252a.

Os resultados do immunoblotting ( $\mathrm{n}=5 /$ grupo) corroboram em geral os dados obtidos na imuno-histoquímica, porém vale lembrar que a técnica de immunoblotting analisa o conteúdo protéico de toda a estrutura removida do encéfalo. Na análise do mesencéfalo temos que ser cautelosos, pois podemos estar quantificando outras fibras e células que não estão na $\mathrm{SNc}$, pois a coleta apenas da SNc torna-se inviável. Além disso, o immunoblotting tem como resultado final um material que permite uma análise quantitativa da densidade óptica, enquanto a imunohistoquímica permite uma análise dos tipos, localização das estruturas imunorreativas e contagem celular. Dados numéricos estão expressos na tabela 3 do apêndice $B$.

\subsubsection{Substância negra pars compacta}

As imagens digitais de cortes coronais da SNc ilustram as mudanças que ocorrem nos níveis de TH nos diferentes grupos após a injeção de 6-OHDA (Figura 20). A contagem celular revelou uma queda na expressão de $\mathrm{TH}$ em ambos os grupos SED (SED - ca. 44\%, p=0,0001; SED+K252a- ca. 69\%; p=0,0001) quando comparados aos grupos CLT (CLT e CLT+K252a), sendo o decréscimo no grupo SED+K252a maior do que no grupo SED group (ca.45\%; $p=0,0001$ ).

No grupo EXA+EXAD houve uma queda no número de células TH-positivas após a injeção de 6-OHDA em relação ao grupo CLT (ca. 23\%, p=0,0001); porém, houve um acréscimo em relação ao grupo SED (ca. 27\%; $p=0,0005$ ). A adição de 
K252a promoveu um acréscimo na perda de neurônios dopaminérgicos (EXA+EXD+K252a) quando comparado aos grupos CLT+K252a (ca. 72\%; $p=0,0001$ ) e $E X A+E X D$ (ca. 64\%; $p=0,0001$ ). O grupo EXD revelou decréscimo na porcentagem de células TH-positivas quando comparado ao grupo CLT (ca.19\%; $\mathrm{p}=0,0003$ ), mas um acréscimo em relação ao grupo SED (ca. $31 \% ; \mathrm{p}=0,0001$ ). Quando se acrescentou K252a, a queda na expressão de TH foi mais intensa (ca. $47 \%$, EXA+K252a; $p=0,0001)[F(3,32)=32,386 ; p=0,000001]$ (Figura 21). 
Figura 20 - Efeitos do exercício em esteira e do bloqueio do receptor de BDNF sobre a expressão de TH na SNc.

\section{Tirosina Hidroxilase - SNc}

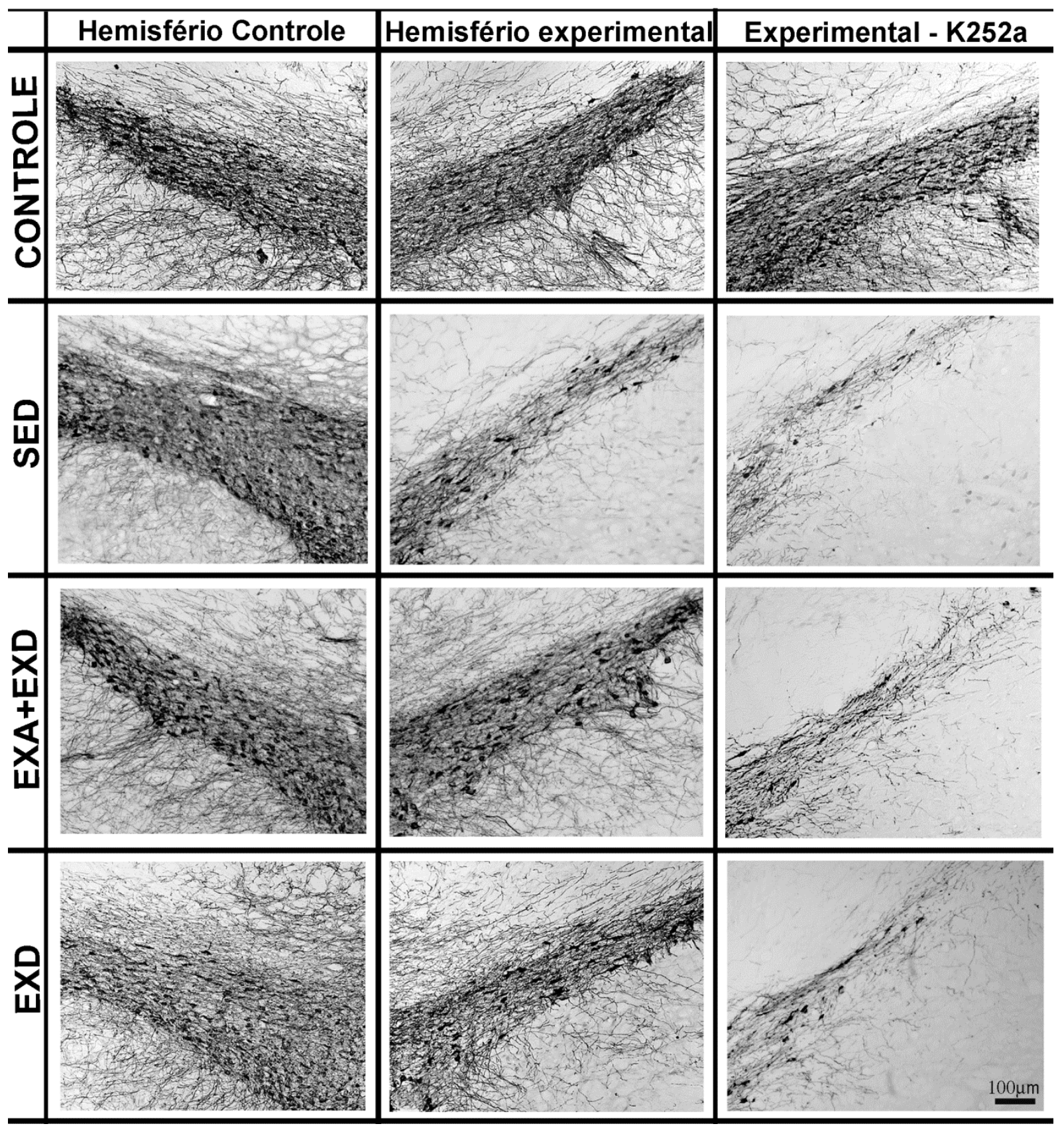

Imagens digitais de cortes coronais da SNc marcados para TH. Bregma aproximado, $+5,2 \mathrm{~mm}$. Note que a redução na expressão de TH observado nos ratos do grupo SED é atenuada após o exercício. O bloqueio do receptor de BDNF, K252a, reverte o efeito protetor do exercício contra a perda de neurônios dopaminérgicos induzida pela injeção de 6-OHDA.

Fonte: Modificado de Real et al., 2013. 
Figura 21 - Efeitos do exercício em esteira e do bloqueio do receptor de BDNF sobre a análise semi-quantitativa da porcentagem de células $\mathrm{TH}$ positivas na SNc.

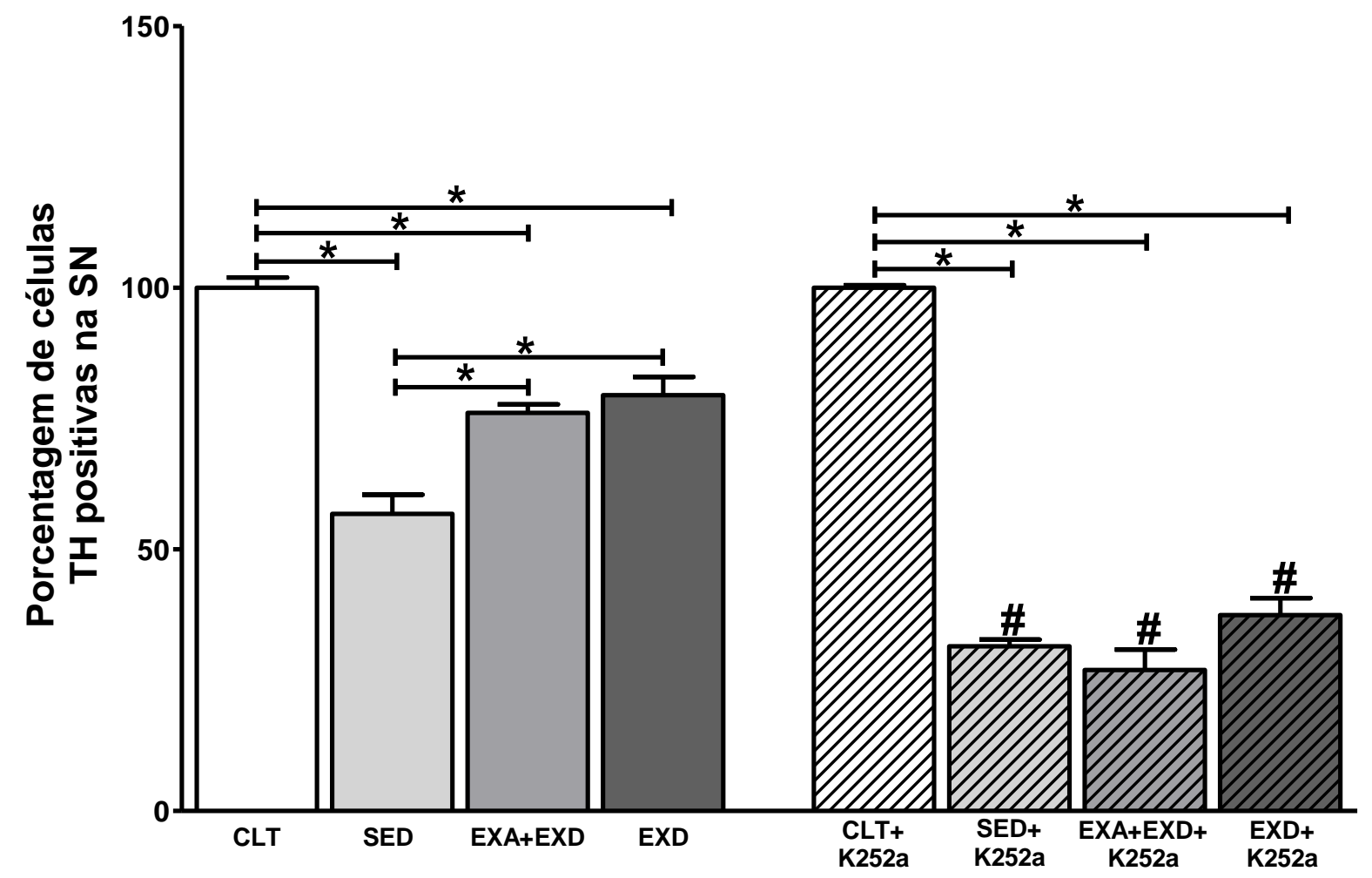

As barras representam a porcentagem de células TH-positivas no hemisfério experimental em relação ao hemisfério controle. O bloqueio do receptor de BDNF, K252a, reverte o efeito protetor do exercício contra a perda de neurônios dopaminérgicos induzida pela injeção de 6-OHDA. ${ }^{*} \mathrm{p}<0.05$; \# indica significância entre o grupo que recebeu K252a e seu correspondente que não recebeu a droga bloqueadora do receptor de BDNF.

Fonte: Modificado de Real et al., 2013.

Os dados de immunoblotting, no mesencéfalo, demonstraram decréscimo nos níveis de TH apenas no grupo SED quando comparado aos outros grupos (CLT - ca. 54\%, p=0,0004; EXA+EXD - ca. 59\%, p=0,0001; EXD - ca. 47\%, p=0,009). Por outro lado, quando se adicionou $\mathrm{K} 252 \mathrm{a}$, todos os grupos que receberam 6-OHDA revelaram decréscimo nos níveis de TH (SED+K252a - ca.42\%, $p=0,006$; $E X A+E X D+K 252 a$ - ca. 38\%; $p=0,01 ; \quad E X D+K 252 a$ - ca.45\%; $p=0,003)$ $[F(3,32)=7,6592 ; p=0.0005]$ (Figura 22). 
Figura 22 - Efeitos do exercício em esteira e do bloqueio do receptor de BDNF sobre os níveis de TH na SNc.

\section{$\mathrm{TH}$ \\ 52KDa \\ $\beta$-actina \\ 42KDa}


As barras representam a razão da densidade óptica entre TH e beta-actina, comparando os hemisférios experimentais de cada grupo. A imagem representa bandas típicas de immunoblots para cada condição experimental. O bloqueio do receptor de BDNF, K252a, reverte o efeito protetor do exercício contra a perda de neurônios dopaminérgicos induzida pela injeção de 6-OHDA. * ${ }^{*}<0.05$; \# indica significância entre o grupo que recebeu K252a e seu correspondente que não recebeu a droga bloqueadora do receptor de BDNF.

Fonte: Modificado de Real et al., 2013. 


\subsubsection{Estriado}

A marcação para TH no CPu revelou mudanças nos diferentes grupos após a injeção de 6-OHDA (Figura 23). A densidade óptica relativa da expressão de TH apresentou um decréscimo nos grupos SED (ca. 55\%; $p=0,0001$ ), e EXD (ca. 32\%; $\mathrm{p}=0,0001$ ) quando comparados com o grupo CLT. Mas quando comparamos o grupo EXD com o grupo SED notamos um acréscimo na densidade de $\mathrm{TH}$ (ca. 34\%, $\mathrm{p}=0,0001$ ). Porém, quando adicionamos K252a, a marcação de TH diminuiu em todos os grupos que receberam 6-OHDA (SED+K252a - ca. 44\%, p=0,0001; $E X A+E X D+K 252 a-c a .47 \%, p=0,0001 ; E X D+K 252 a-c a .35 \%, p=0,0001)$ quando comparados com o grupo CLT+K252a group $[F(3,32)=47,436 ; p=0,000001]$ (Figura 24).

Os resultados de immunoblotting foram semelhantes aos encontrados na imuno-histoquímica. Os níveis de TH diminuíram no grupo SED quando comparados aos outros grupos (CLT - ca. 76\%, p=0,0001; EXA+EXD - ca. 80\%, p=0,0001; EXD - ca. 73\%, $p=0,0001)$. Os grupos que receberam K252a e 6-OHDA demonstraram um decréscimo nos níveis de $\mathrm{TH}$ quando comparados ao grupo CLT+K252a (SED+K252a - ca. 66\%, p=0,0001; EXA+EXD+K252a - ca. 37\%, p=0,0007; EXD+K252a - ca. 54\%, p=0,0001). Além disso, os grupos exercitados que receberam K252a apresentaram piora nos níveis de $\mathrm{TH}$ quando comparados aos mesmos grupos que não receberam o bloqueador (EXA+EXD+K252a - ca. 48\%; EXD+K252a - ca. 49\%; $p=0,0007) \quad[F(3,32)=10,029 ; p=0,00008]$ (Figura 25).

Todos os dados obtidos na SNc e CPu através das técnicas de imunohistoquímica e immunoblotting estão resumidos na tabela 3 no apêndice $\mathbf{B}$. 
Figura 23 - Efeitos do exercício em esteira e do bloqueio do receptor de BDNF sobre a expressão de TH no CPu.

\section{Tirosina Hidroxilase - CPu}

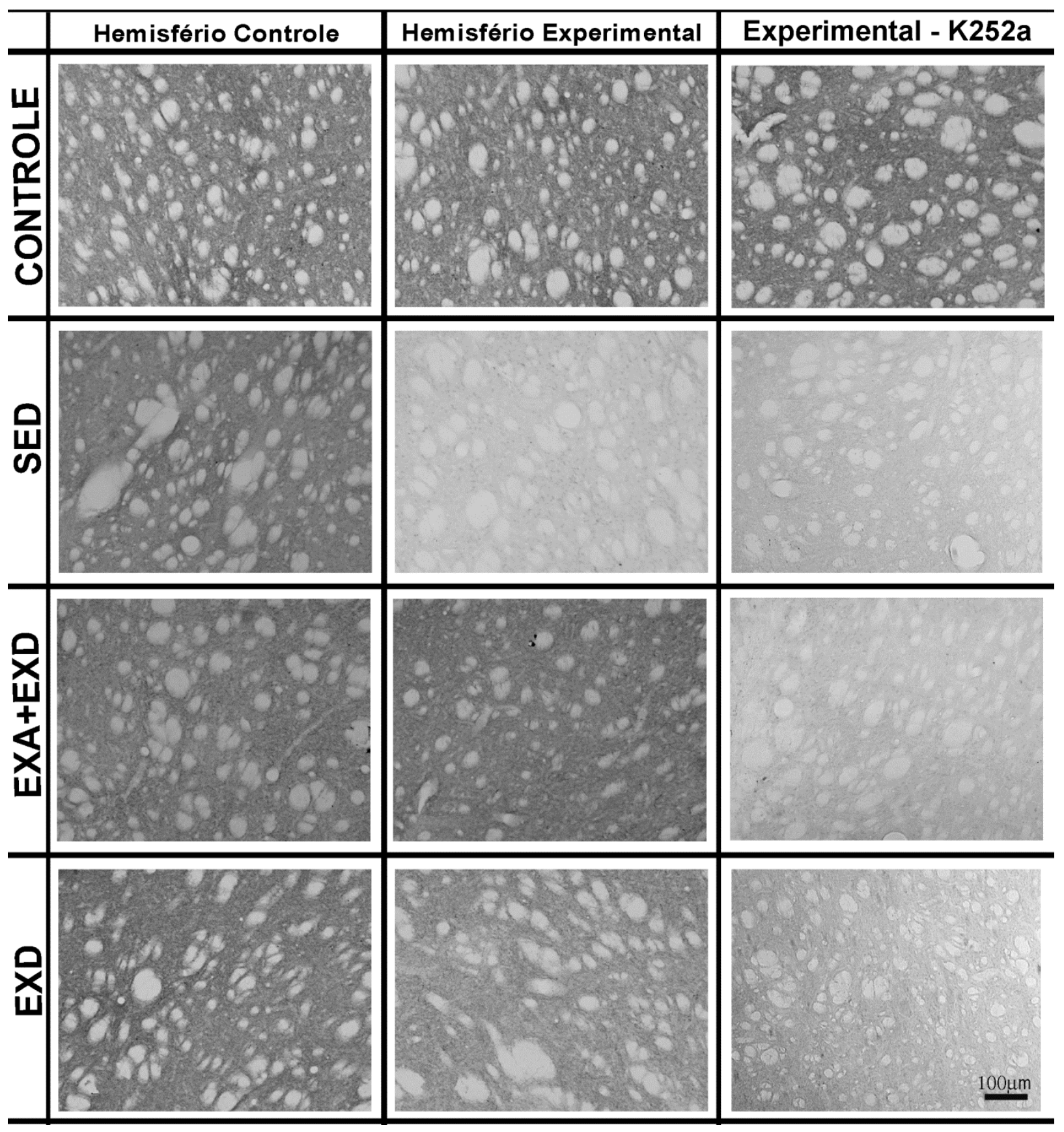

Imagens digitais de cortes coronais do CPu marcados para TH. Bregma aproximado, $+1,56 \mathrm{~mm}$. Note que a redução na expressão de TH observada nos ratos do grupo SED é atenuada após o exercício. O bloqueio do receptor de BDNF, K252a, reverte o efeito protetor do exercício contra a perda de terminais dopaminérgicos induzida pela injeção de 6OHDA.

Fonte: Modificado de Real et al., 2013. 
Figura 24 - Efeitos do exercício em esteira e do bloqueio do receptor de BDNF sobre a expressão de TH em terminações dopaminérgicas no CPu.

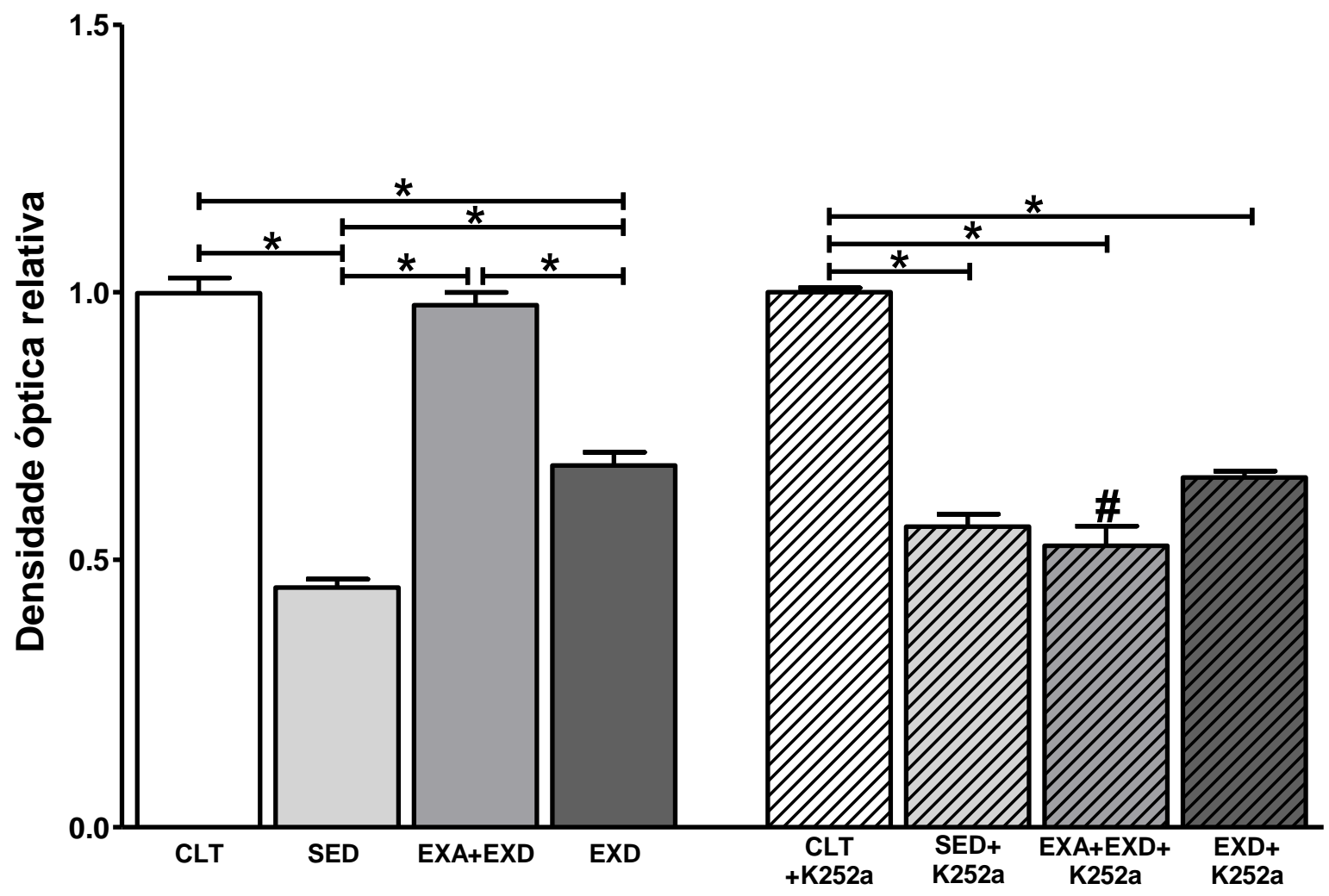

As barras representam a razão da densidade óptica de terminações dopaminérgicas no hemisfério experimental em relação ao hemisfério controle. O bloqueio do receptor de BDNF, K252a, reverte o efeito protetor do exercício contra a perda de terminais dopaminérgicos induzida pela injeção de 6-OHDA. * $\mathrm{p}<0.05$; \# indica significância entre o grupo que recebeu K252a e seu correspondente que não recebeu a droga bloqueadora do receptor de BDNF.

Fonte: Modificado de Real et al., 2013. 
Figura 25 - Efeitos do exercício em esteira e do bloqueio do receptor de BDNF sobre os níveis de TH no CPu.
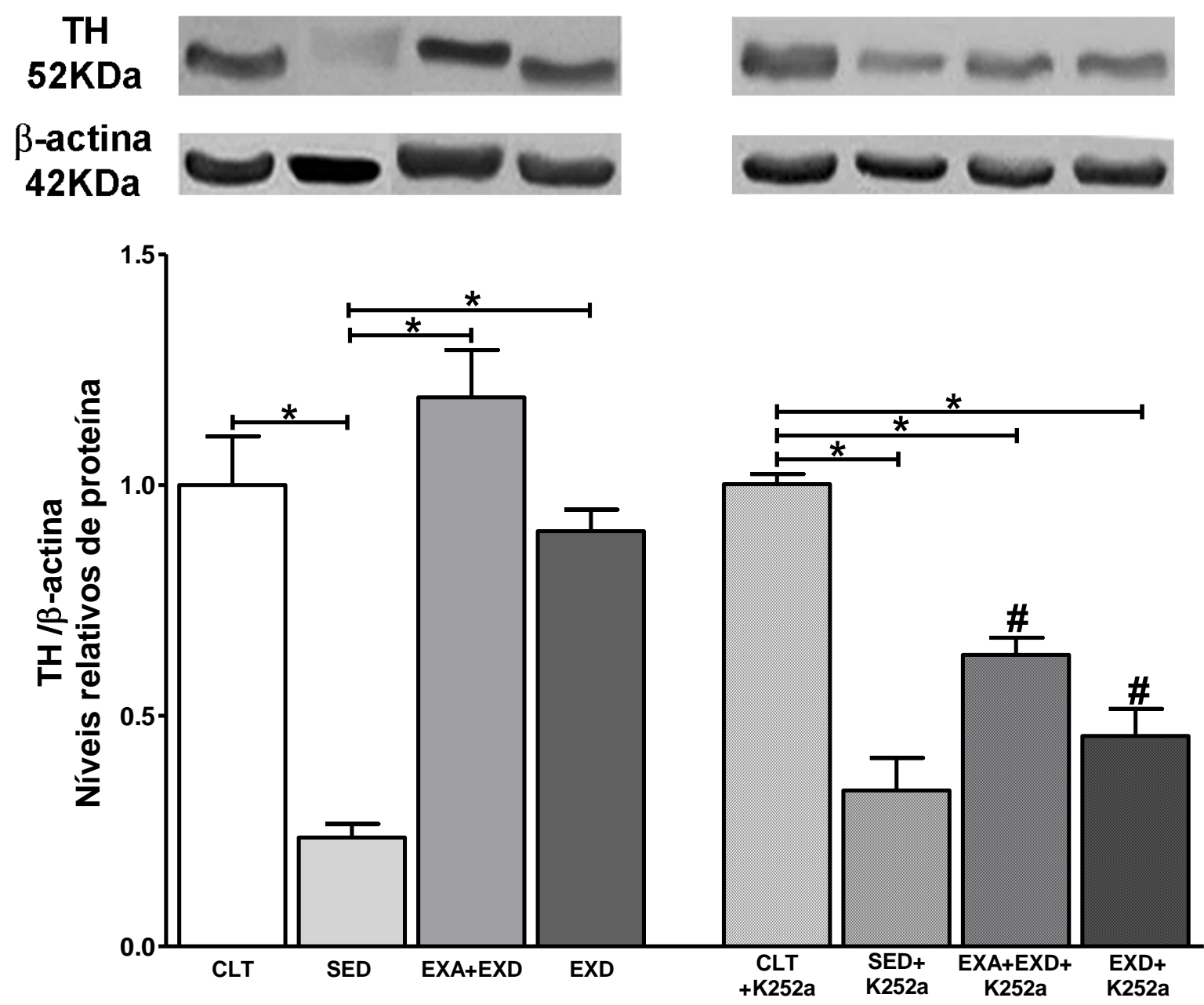

As barras representam a razão da densidade óptica entre TH e beta-actina, comparando os hemisférios experimentais de cada grupo. A imagem representa bandas típicas de immunoblots para cada condição experimental. O bloqueio do receptor de BDNF, K252a, reverte o efeito protetor do exercício contra a perda de terminais dopaminérgicos induzida pela injeção de 6-OHDA. * $\mathrm{p}<0.05$; \# indica significância entre o grupo que recebeu K252a e seu correspondente que não recebeu a droga bloqueadora do receptor de BDNF.

Fonte: Modificado de Real et al., 2013. 


\section{$\underline{4.3 \text { Discussão }}$}

O propósito deste estudo foi investigar o impacto do protocolo de exercício intermitente sobre o modelo da DP induzida por 6-OHDA, e analisar o possível envolvimento do BDNF, uma neurotrofina que parece ter um papel crítico nos mecanismos de neuroproteção induzido pelo exercício (Blum et al., 2001; Mattson, 2008; Nguyen et al. 2009; Tajiri et al., 2010; Zigmond et al., 2009; Wu et al., 2011). Em geral, o exercício intermitente em esteira empregado neste estudo produziu um acréscimo nos níveis de BDNF nos ratos parkinsonianos, independente do bloqueio do receptor de BDNF. Notamos um claro efeito neuroprotetor do exercício após a injeção de 6-OHDA, pois houve menor déficit de TH no CPu e SNc após o treino. Porém, este efeito foi eliminado após o bloqueio do receptor de BDNF com K252a. Além disso, os dados comportamentais levaram à mesma conclusão. Porém, enquanto 0 teste rotacional demonstrou melhoras relacionadas com 0 comportamento motor, os resultados obtidos no CA não revelaram alterações motoras, mas sim mudanças que podem estar envolvidas com o comportamento cognitivo dos animais. Assim, iremos primeiramente discutir o envolvimento do BDNF nas alterações neuroquímicas e comportamentais no modelo da DP, e posteriormente o fator cognitivo encontrado em nosso estudo.

\subsubsection{Envolvimento do BDNF nas alterações neuroquímicas e comportamentais no modelo da DP}

Neste momento iremos discutir os dados referentes aos níveis de $\mathrm{TH}$ em ambas as técnicas, os dados do teste de rotação e o efeito do bloqueio do receptor de BDNF sobre estes mecanismos.

Diversos protocolos de exercício vêm sendo utilizados com o objetivo de analisar os efeitos sobre as funções do cérebro, e possíveis funções terapêuticas em distúrbios do SNC, como por exemplo, a DP. Porém, os resultados encontrados na literatura são controversos, tendo em vista que mudanças nos protocolos, tais como modalidade, intensidade e frequência, são capazes de promover respostas distintas ao SNC (Arida et al., 2011), assim, muitas questões continuam sem respostas. Além disso, nosso estudo é a primeiro a descrever benefícios promovidos pelo exercício intermitente em esteira no modelo da DP, e o envolvimento do BDNF nestes efeitos. 
Alguns dos estudos que mostraram os efeitos do exercício contínuo (5x/semana) em modelos da DP encontraram diminuição nos déficits de DA no CPu e SNc, neuroproteção de células dopaminérgicas (Lau et al., 2011; Petzinger et al., 2007; Tajiri et al., 2010; Yoon et al., 2007), e recuperação das funções motoras, como foi demonstrado através dos testes rotacionais induzido por apomorfina (Kirik et al., 1998; Yoon et al., 2007) ou anfetamina (Tajiri et al., 2010), capazes de avaliar o comportamento motor dos animais, além de melhoras nos níveis de fatores neurotróficos, que se encontram diminuídos em doenças neurodegenerativas (Lau et al., 2011; Tajiri et al., 2010; Wu et al., 2011).

A injeção de $20 \mu \mathrm{g}$ de 6-OHDA no CPu de ratos, ou seja, uma dose $130 \%$ maior do que a utilizada em nosso protocolo, associada ao treino no dia seguinte à lesão (exercício leve (3m/min), 14 dias consecutivos por 30 minutos) foi capaz de promover melhora na expressão de TH tanto na SNc quanto no CPu (Yoon et al., 2007). Os efeitos do exercício também foram observados em camundongos submetidos ao modelo da DP por MPTP, esses animais foram treinados $5 \mathrm{x} /$ semana por uma semana antes da injeção de MPTP, 5 semanas durante a instalação da DP e 12 semanas após a indução. Após o protocolo notou-se acréscimo nos níveis de $\mathrm{TH}$ tanto na SNc quanto no $\mathrm{CPu}$, ou seja, decréscimo na perda de células dopaminérgicas, além de melhora nos níveis de DA e do DAT no CPu, e consequentemente melhoras no equilíbrio e coordenação motora (Lau et al., 2011). Outro estudo em camundongos também demonstrou melhoras nos níveis dopaminérgicos nos animais treinados em esteira 5x/semana por um período de 28 dias (Petzinger et al., 2007).

Além dos protocolos de exercício em esteira, outro estudo demonstrou que o exercício voluntário em roda, durante 2 semanas e meia antes da injeção intracerebral de 6-OHDA e 4 semanas após a operação, foi capaz de promover melhora do sistema dopaminérgico nigroestriatal sem induzir neuroproteção (O’Dell et al., 2007). Logo, há uma concordância em relação aos efeitos benéficos do exercício sobre a melhora do comportamento motor dos animais; entretanto, a proteção dos neurônios dopaminérgicos contra os efeitos da neurotoxina é controversa (Zigmond et al., 2009). 
Em nosso estudo, ambos os protocolos de exercício utilizados (EXA+EXD e EXD) produziram um efeito neuroprotetor sobre as células dopaminérgicas, pois notamos um número grande de células TH-positivas na SNc dos grupos treinados. Esta neuroproteção de células dopaminérgicas resulta em níveis elevados de TH no $\mathrm{CPu}$, semelhantes aos níveis do grupo CLT. Além da melhora nos níveis de $\mathrm{TH}, \mathrm{o}$ teste comportamental demonstrou decréscimo na assimetria rotacional dos animais dos grupos treinados (EXA+EXD e EXD) em relação ao grupo SED. Assim, os resultados comportamentais corroboram os achados neuroquímicos, assim como demonstrado por outros estudos, onde a perda de TH e da concentração de DA está diretamente relacionada com o aumento da assimetria induzida por apomorfina (Henderson et al., 2003; Yoon et al., 2007).

Assim, nosso estudo mostrou pela primeira vez que o exercício intermitente em esteira é capaz de promover efeito neuroprotetor, demonstrado por melhora tanto no comportamento motor quanto nas respostas neuroquímicas, ou seja, complementa os dados com exercício contínuo (Lau et al., 2011; Petzinger et al., 2007; Tajiri et al., 2010; Yoon et al., 2007). Apesar dos dados para exercício continuo e para o exercício intermitente serem similares, devemos lembrar que o protocolo de exercício intermitente pode ser mais benéfico em relação ao protocolo contínuo pelo fato de ser mais próximo da realidade dos pacientes parkinsonianos (Herman et al., 2007). Além disso, deve-se ressaltar que não encontramos quaisquer efeitos do exercício sobre os níveis de TH e os efeitos comportamentais em animais não parkinsonianos, como já foi demonstrado com um protocolo de exercício contínuo (Yoon et al., 2007).

Outro ponto interessante que devemos citar são os diferentes resultados encontrados quando relacionamos os dois protocolos de exercício. O grupo EXA+EXD apresentou melhores resultados nos níveis de $\mathrm{TH}$ no $\mathrm{CPu}$ quando comparados ao grupo EXD. O grupo EXA+EXD exibiu diminuição no número de células TH-positivas, mas manteve os níveis dopaminérgicos no CPu semelhante ao grupo CLT, e revelou redução dos sintomas motores. Assim, podemos sugerir que quando EXA+EXD recebeu a neurotoxina, o sistema nervoso já estava protegido, ou seja, mecanismos protetores já haviam sido ativados pelo exercício, como por exemplo, sistemas antioxidantes endógenos, aumento da ação do BDNF (Blum et al., 2001, Devi, Kiran, 2004; Mattson, 2008), e diminuição da apoptose (Mocchetti et 
al., 2007). Além disso, é possível que no grupo EXD, ao iniciar o protocolo de exercício, a droga já havia iniciado os mecanismos de morte celular, tendo em vista que logo após a injeção ela já tem efeitos deletérios sobre o sistema catecolaminérgico, e assim o exercício não pode reverter completamente os danos promovidos pela neurotoxina. Zigmond e colaboradores (2009) revisaram que o exercício pode não exatamente proteger as células dopaminérgicas, mas pode permitir que as células dopaminérgicas restantes, assim como outros componentes dos gânglios da base, melhorem sua capacidade de resposta à DA e/ou apresente repostas compensatórias à perda dos neurônios dopaminérgicos. Os neurônios residuais no modelo da DP por 6-OHDA podem aumentar a síntese e liberação de DA.

Tendo em vista os efeitos benéficos do exercício intermitente em esteira, analisamos os níveis de BDNF. O BDNF é um fator envolvido em muitos dos efeitos benéficos promovidos pelo exercício no sistema nervoso (Blum et al., 2001; Mattson, 2008; Nguyen et al. 2009; Tajiri et al., 2010; Zigmond et al., 2009; Wu et al., 2011). Ambos os protocolos de exercício físico propostos em nosso estudo foram capazes de recuperar os níveis de BDNF na SNc em relação aos animais sedentários parkinsonianos. Os animais treinados parkinsonianos expressarm níveis de BDNF similares ao encontrado no grupo CTL, ou seja, animais não parkinsonianos. A manutenção nos níveis de BDNF ocorreu nos mesmos grupos que apresentaram melhora nos níveis de TH e do comportamento motor, nomeados de EXA+EXD e EXD. Por outro lado, não houve mudanças nos níveis da neurotrofina no CPu. Assim, nossos achados sugerem que o BDNF pode participar dos efeitos neuroprotetores promovidos pelo exercício.

O acréscimo nos níveis de BDNF na SNc dos grupos treinados confirma que o protocolo de exercício em esteira foi capaz de promover mudanças nos níveis de BDNF. O BDNF, por sua vez, via ativação de seu receptor (TrkB), é capaz de ativar mecanismos relacionados com a sobrevivência de neurônios dopaminérgicos da via nigroestriatal (Baydyuk et al., 2011; Wu et al., 2011). O acréscimo de fatores neurotróficos pode ser de extrema importância na proteção contra a neurotoxina, pelas suas ações diretas e indiretas (Nguyen et al., 2009). Exemplos de tais ações são observadas em estudos que demonstraram inibição da apoptose e da degeneração de neurônios dopaminérgicos, e consequentemente diminuição da 
morte neuronal (Binder, Scharfman, 2004). O BDNF também ativa vias de sinalização que modulam a transcrição do fator $\mathrm{NF}_{\kappa} \mathrm{B}$, que, por sua vez, induz a síntese de enzimas antioxidantes e proteínas anti-apoptóticas (Mattson, 2008). Nossos achados corroboram outro estudo com o modelo da DP, o qual revelou que os níveis de BDNF são muito importantes para a proteção celular e manutenção da expressão de TH, (Tajiri et al., 2010), especialmente na SNc (Lau et al., 2011). A sinalização de BDNF via receptores TrkB é reconhecidamente importante para a sobrevivência de neurônios dopaminérgicos (Bayduk et al., 2011).

Para confirmarmos o envolvimento do BDNF nos efeitos neuroprotetores induzidos pelo exercício no presente modelo, nos injetamos K252a no CPu para bloquear a sinalização de BDNF via receptores TrkB. Após o bloqueio dos receptores, os níveis de TH caíram significantemente, inclusive nos grupos treinados $(E X B+E X A+K 252 a$ and $E X A+K 252 a)$, sem que houvesse alterações nos níveis de BDNF. Estes achados correlacionam-se com a piora da atividade motora observada no teste com apomorfina; a assimetria rotacional foi similar à encontrada nos grupos sedentários (SED e SED+K252a), ou seja, houve um aumento da assimetria nos grupos exercitados e tratados com $\mathrm{K} 252 \mathrm{a}$ quando comparados com os grupos EXA+EXD e EXD.

Assim, podemos sugerir que o bloqueio da sinalização BDNF-TrkB está envolvido com a piora nos efeitos neuroprotetores promovidos pelo exercício após a injeção de K252a. A diminuição nos níveis de TH também foi descrita em camundongos exercitados, sendo que nesse estudo os camundongos receberam injeção intra-cérebro-ventricular de $\mathrm{K} 252 \mathrm{a}$ antes da indução da morte de células dopaminérgicas por LPS. Além da diminuição dos níveis de TH notou-se e uma queda de receptores TrkB fosforilados (pTrkB) (Wu et al., 2011). Apesar de nossos resultados corroborarem esses achados, a injeção intraperitoneal de LPS utilizado nesse estudo promove uma rápida inflamação da SNc e em outras regiões do cérebro (Blum et al., 2001), enquanto o modelo da DP com 6-OHDA promove um processo de morte menos agressiva e mais seletiva das células dopaminérgicas (Schober, 2004; Tillerson et al., 2002). Logo, com estas descrições, podemos sugerir que para não ocorrer prejuízo nos níveis de TH, os níveis de BDNF devem ser pelo menos semelhantes aos do animal controle e não necessariamente sofrer acréscimo, e também ter seus receptores funcionais. Na maioria dos estudos citados 
acima a neuroproteção estava associada à ausência de queda de BDNF no hemisfério lesado e à não inibição dos receptores TrkB.

Efeitos similares foram descritos em humanos. Achados clínicos indicam que o exercício melhora a marcha, a mobilidade, e a qualidade de vida dos pacientes com a DP, diminuindo assim, o risco de queda, principal responsável pela morte em idosos. O treino físico é capaz de promover um padrão de marcha mais estável nos pacientes com a DP, e, além disso, um programa de intervenção de caminhada em esteira por um longo período é capaz de recuperar a ritmicidade da marcha. (Herman et al., 2007) e o equilíbrio nos pacientes parkinsonianos (Toole et al., 2000). Talvez, a melhora clínica observada nos pacientes com a DP deve-se à normalização da excitabilidade corticomotora promovida pelo exercício em fases iniciais da DP (Fisher et al., 2008). Em adição à melhora clínica, o exercício físico promover aumento nos níveis séricos de BDNF, capaz de cruzar a barreira hematoencefálica (Ahlskog, 2011), e diminuir o risco de desenvolver a DP (Chen et al., 2005; Sasco et al., 1992), sugerindo que o exercício de fato exerce efeitos neuroprotetores.

\subsubsection{Envolvimento cognitivo na DP}

O teste no CA, inicialmente, foi realizado com o objetivo de quantificar a frequência de locomoção do animal e medir mudanças motoras, ou seja, complementar os dados encontrados na análise do teste rotacional induzido por apomorfina. Porém, ao analisarmos os resultados do teste notamos que não houve mudanças na frequência de locomoção após 7 dias do procedimento cirúrgico, ocorrendo a mudança apenas com 30 dias de cirurgia. Além disso, ao compararmos os dados da primeira e da segunda exposição dos animais ao CA, notamos que os animais que apresentaram maiores déficits de DA e maior comprometimento no teste rotacional foram os que apresentaram maior frequência de locomoção, ou seja, algo contraditório. Assim, fomos à busca de uma explicação aceitável na literatura, e concluímos que a forma com que o teste foi realizado mediu a capacidade de o animal relembrar o local ao qual foi exposto, uma avaliação simples da memória de habituação do animal em longo prazo, ou seja, uma avaliação cognitiva e não motora. Um grupo que mediu efeitos do haloperidol sobre a bradicinesia de animais 
submetidos a um modelo da DP, também relatou uma queda da distância percorrida no CA pelos animais controles, quando a segunda exposição ocorreu depois de 3 semanas da primeira exposição. O grupo discutiu em seu trabalho que este achado não está relacionado com a bradicinesia do animal, podendo estar envolvido outro fator (Baptista et al., 2013). A DP tem sido constantemente associada a déficits de memória principalmente em sua fase inicial, podendo estar associada às alterações no circuito fronto-estriato-talâmico, devido aos déficits de DA (revisado por Melo et al., 2007), ou mesmo à morte de neurônios noradrenérgicos, no locus coeruleus (Pérez et al., 2007; Zarow et al., 2003). Temos alterações dos sistemas dopaminérgicos, noradrenérgicos, serotoninérgicos e colinérgicos, e consequentemente prejuízos comportamentais e cognitivos. Estes sintomas, por sua vez, costumam aparecer antes mesmo dos sintomas motores. Com estas alterações temos mudanças sinápticas, no metabolismo cortical, nas funções mitocondriais e da produção de energia, danos oxidativos, na transcrição, na expressão de proteínas, na composição lipídica e no sistema de autofagia, causando transtornos em todo o sistema (Ferrer et al., 2012). Sendo o nosso estudo baseado em um modelo da DP que representa fases iniciais da doença, com a injeção feita no CPu e em pequena concentração de 6-OHDA (Deumens et al., 2002), sugerimos que os achados nos grupos EXA+EXD e EXD no CA estão relacionados com melhora na cognição destes animais, devido a melhora do sistema dopaminérgico (aumento da expressão de TH nestes grupos);

Fornaguera e colaboradores (1999) demonstraram que só há diferença do comportamento de locomoção na primeira exposição nos animais com mais de $80 \%$ de morte celular (7 dias após a injeção de 6-OHDA, ou seja, depleção severa de $\mathrm{TH}$ ), enquanto os animais com menos de $55 \%$ de morte não demonstraram alteração significante. Logo, nosso estudo corrobora a descrição anterior, pois os animais não apresentaram diferença de locomoção na primeira exposição (Figura $15 \mathrm{~A})$, tendo em vista que o nosso modelo promoveu uma morte gradual dos neurônios dopaminérgicos (Schober, 2004; Tillerson et al., 2002). Outros estudos demonstraram diminuição da frequência de locomoção no modelo da DP, porém estes utilizaram protocolos mais agressivos para indução da morte celular (Bové et al., 2005), por meio da injeção de grande quantidade de 6-OHDA no feixe prosencefálico medial (Rizelio et al., 2010; Winner et al., 2009). No entanto, na 
segunda exposição houve um aumento da locomoção nos animais do grupo SED se comparados aos outros grupos (Figura 15B); notamos que os outros animais diminuíram a locomoção na segunda exposição enquanto os animais do grupo SED mantiveram a frequência de locomoção igual à observada na primeira exposição (Figura 16A e B). Este achado reforça a ideia de um comprometimento cognitivo, sugerindo assim, uma memória de habituação por parte dos animais que apresentaram melhores níveis de $\mathrm{TH}$ na SNc e $\mathrm{CPu}$, e consequentemente uma melhora na cognição e possivelmente na memória de longo prazo destes animais. Os animais treinados, por sua vez, apresentaram dados semelhantes ao grupo CLT, ou seja, parece que o exercício foi capaz de promover benefícios cognitivos. Por outro lado, o bloqueio com K252a promoveu aumento na frequência de locomoção e no déficit de TH, ficando semelhante ao grupo SED. Assim, fica evidente que o comportamento exploratório do animal está diretamente relacionado com os níveis de $\mathrm{TH}$, e que o exercício físico foi capaz de promover habituação da memória de longo prazo dos animais. Andringa e colaboradores (2000), também em um modelo da DP, demonstraram que quanto maior o déficit dopaminérgico, maior a locomoção dos animais no CA devido a um comprometimento cognitivo. Outro estudo com o modelo da doença de Alzheimer em animais transgênicos demonstrou que, quanto mais comprometida a cognição do animal, maior a locomoção dele, mesmo quando exposto por três dias seguidos ao CA (Walker et al., 2011). Assim, podemos sugerir que o protocolo deste estudo foi capaz de promover melhoras cognitivas nos animais treinados que não receberam o inibidor de TrkB, já que eles foram capazes de apresentar a memória de habituação em longo prazo, assim como os animais do grupo CLT, ou seja, animais livres de doenças neurodegenerativas. Porém, outras análises do CA, tais como, tempo de imobilidade, tempo de mobilidade, velocidade média (Baptista et al., 2013), e outros testes específicos poderiam ser úteis para concluirmos melhor os efeitos cognitivos e motores encontrados nos animais. Para isto, poderíamos utilizar o teste de reconhecimento de objetos, o teste de CA para memória em curto prazo, labirinto de Barnes, etc (Mello et al., 2008; Walker et al., 2011). 


\section{$\underline{4.4 \text { Conclusões }}$}

Os resultados descritos acima demonstram que o modelo da DP é capaz de alterar os níveis de TH e BDNF. Notamos que o exercício de forma geral foi capaz de promover benefícios ao modelo da DP, sendo capaz de promover melhoras nos déficits de BDNF e de TH que foram encontrados nos grupos SED. Por outro lado, o bloqueio dos receptores TrkB em geral promoveu aumento nos déficits de TH apesar de os níveis de BDNF estarem relativamente inalterados. Em adição, os dados comportamentais corroboram os resultados neuroquímicos, onde o teste rotacional revelou uma melhora motora e o CA sugere uma melhora cognitiva.

Em resumo, nossos dados revelaram que o exercício intermitente promoveu uma melhora no sistema dopaminérgico, capaz de recuperar o comportamento motor e cognitivo dos ratos injetados com 6-OHDA. Demonstramos ainda que o beneficio promovido pelo exercício intermitente parece ter o envolvimento do sistema BDNF-TrkB, sugerindo ser este um importante sistema neuroprotetor. 


\section{CAPÍTULO 5 - POSSÍVEL EFEITO PREVENTIVO DO EXERCÍCIO FÍSICO NA NEUROTOXICIDADE INDUZIDA PELA INJEÇÃO DE 6-OHDA EM RATOS TREINADOS}

Neste capítulo o foco de nosso estudo foi investigar o papel preventivo do exercício no desenvolvimento da DP induzida por injeção intraestriatal de 6-OHDA, e os mecanismos envolvidos nestes efeitos. Apenas um estudo analisou 0 envolvimento do exercício como prevenção da instalação do modelo da DP por LPS (Wu et al., 2011); os outros estudos analisaram o efeito do exercício prévio associado ao efeito após a indução do modelo da DP, ou seja, os animais praticaram exercício antes e depois da indução do modelo da DP (Lau et al., 2011; O’Dell et al., 2007; Real et al., 2013). Assim, nesta parte do estudo o período da prática do protocolo de exercício foi antes da indução da DP. Os animais foram treinados por um mês, permanecendo em repouso após o protocolo cirúrgico.

\section{$\underline{5.1 \text { Desenho experimental }}$}

Primeiramente, dividimos os animais em dois grandes grupos: (1) aqueles que receberam a injeção intraestriatal de K252a (o inibidor de TrkB) com o objetivo de bloquear as ações do BDNF (Kafitz et al., 1999); (2) aqueles que não receberam 0 bloqueador do receptor de BDNF. Estes grupos foram então divididos em 4 subgrupos, totalizando 8 sub-grupos.

(1) animais que receberam a injeção intraestriatal de salina e não foram submetidos ao exercício em esteira, designados como sedentários (SED e SED+K252a). Este grupo representa os dados de animais Sham (Yoon et al., 2007; Real et al., 2013);

(2) animais que receberam a injeção intraestriatal de salina e foram submetidos ao exercício em esteira 3 vezes por semana, durante 4 semanas antes, da indução da DP, designados como exercitados (EX e EX+K252a);

(3) animais que receberam a injeção intraestriatal de 6-OHDA e não foram submetidos ao exercício em esteira, designados como sedentários parkinsonianos (SED+DP e SED+DP+K252a);

(4) animais que receberam a injeção intraestriatal de 6-OHDA e foram submetidos ao exercício em esteira 3 vezes por semana, durante 4 semanas antes 
da indução da DP, designados como exercitados parkinsonianos (EX+DP e $\mathrm{EX}+\mathrm{DP}+\mathrm{K} 252 \mathrm{a})$;

Com 2 meses de idade os animais do grupo EX iniciaram o protocolo de exercício; com 3 meses de idade os animais receberam as injeções intraestriatais (6OHDA, salina e K252a); 7 dias após o procedimento cirúrgico, fase mais aguda da indução da DP, uma parte dos animais do grupo que não recebeu K252a foi sacrificada e as estruturas de interesse foram coletadas e submetidas às técnicas de imuno-histoquímica (TH, GFAP e OX42), immunoblotting (TH, GFAP e iNOS), DHE e ELISA para dosagem de BDNF.

Com 4 meses de idade, ou seja, 29 dias após o procedimento cirúrgico, outro grupo de animais foi submetido ao teste rotacional, e um dia após, eutanasiados. As estruturas de interesse foram coletadas e submetidas às técnicas de imunohistoquímica e immunoblotting para análise dos níveis de $\mathrm{TH}$ nos animais que receberam ou não o bloqueador de K252a. Neste grupo analisamos um período mais tardio do efeito do exercício na instalação e prevenção da DP, e o papel do BDNF nestes efeitos. A Figura 26 resume de modo geral as etapas do protocolo. 
Figura 26 - Desenho experimental.

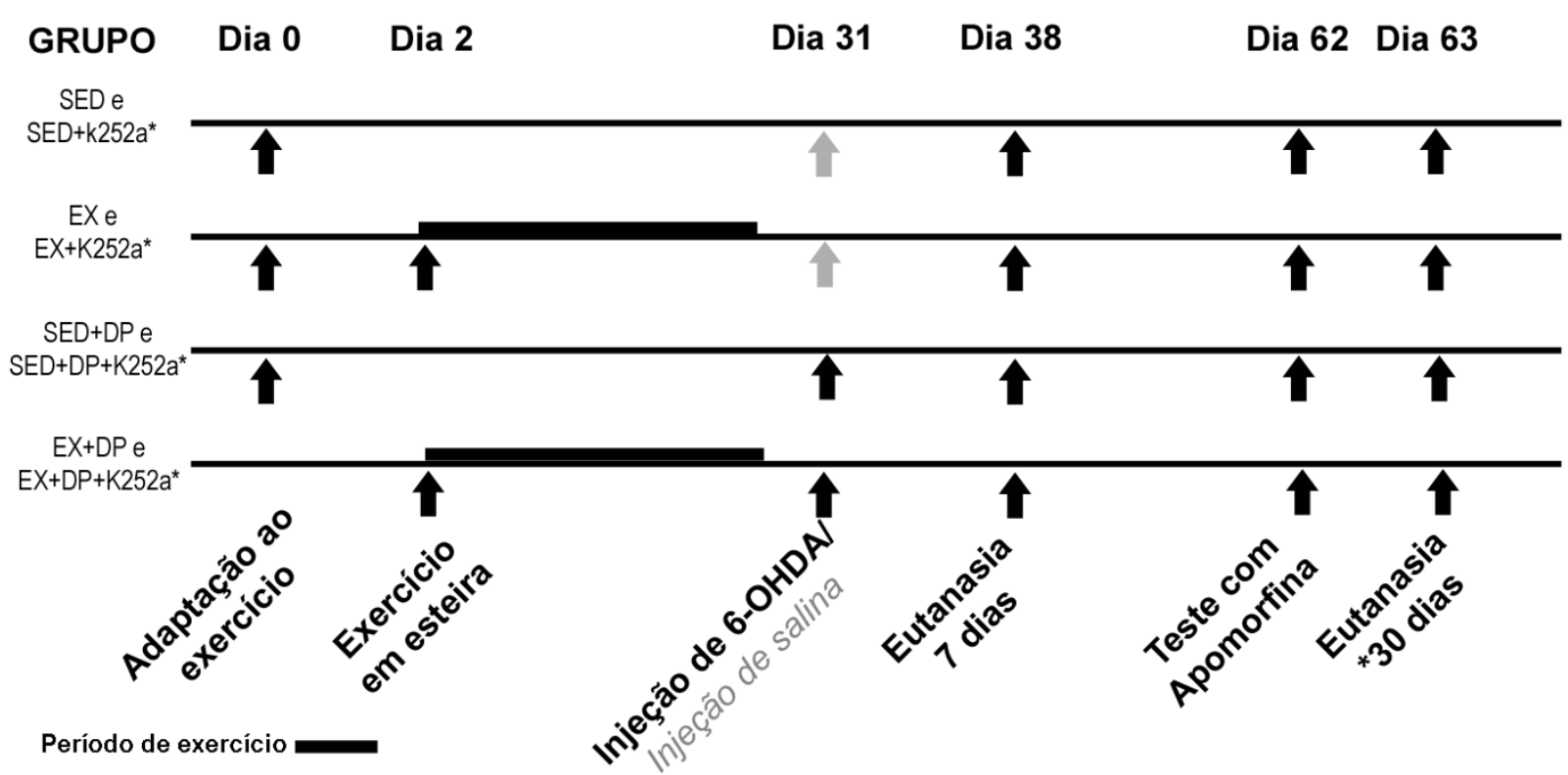

Os ratos exercitados foram submetidos ao protocolo de exercício em esteira 4 semanas antes da injeção de 6-OHDA ou salina (3x/semana, 40 minutos). Sedentários (SED; SED+K252a); exercitados (EX; EX+K252a); sedentários parkinsonianos (SED+DP; $\mathrm{SED}+\mathrm{DP}+\mathrm{K} 252 \mathrm{a})$; exercitados parkinsonianos (EX+DP; EX+DP+K252a). * Os grupos nomeados como SED+K252a, EX+K252a, SED+DP+K252a; EX+DP+K252a, receberam o bloqueador do receptor de BDNF (K252a) juntamente com a injeção de 6-OHDA ou salina; os efeitos só foram analisados no grupo sacrificado no $30^{\circ}$ dia após a cirurgia estereotáxica. Nos ratos eutanasiados no $7^{\circ}$ dia após a cirurgia estereotáxica, analisaram-se os efeitos do exercício em uma fase mais aguda através das técnicas de imuno-histoquímica (TH, GFAP e OX42), immunoblotting (TH, GFAP e iNOS), DHE ou dosagem de BDNF por ELISA. Já os efeitos mais tardios foram analisados no $30^{\circ}$ dia após a cirurgia. Após a avaliação comportamental, os animais foram eutanasiados e os níveis de $\mathrm{TH}$ nas estruturas de interesse analisados através das técnicas de imuno-histoquímica e immunoblotting. 


\section{$\underline{5.2 \text { Resultados }}$}

Antes de descrevermos os resultados devemos ressaltar que o exercício, por si só, não promoveu mudanças em nenhuma das análises realizadas. Os efeitos observados, descritos adiante, referem-se aos efeitos do exercício no modelo da DP. Os resultados, em sua grande maioria, revelaram déficits de $\mathrm{TH}$ e acréscimo dos marcadores de neuroinflamação em ambas as estruturas dos animais sedentários injetados com 6-OHDA, enquanto o exercício foi capaz de prevenir o desenvolvimento destes quadros da DP. Por outro lado, o bloqueio do receptor de BDNF, K252a, produziu piora no quadro dos animais treinados parkinsonianos.

Outra observação relevante é em relação à técnica de immunoblotting. Os resultados desta técnica corroboram em geral os dados obtidos na imunohistoquímica, porém vale lembrar que a técnica de immunoblotting analisa o conteúdo protéico de toda a estrutura removida do encéfalo. Na análise do mesencéfalo temos que ser cautelosos, pois podemos estar quantificando outras fibras e células que não estão exatamente na SNc, pois a coleta apenas da SNc torna-se inviável. Além disso, o immunoblotting tem como resultado final um material que permite uma análise quantitativa da densidade óptica, enquanto a imunohistoquímica permite uma análise dos tipos, localização das estruturas imunorreativas e contagem celular. Dados numéricos estão expressos nas tabelas 1 e 3 do apêndice $C$.

\subsubsection{Teste Comportamental}

O teste comportamental ( $n=10 /$ grupo) realizado foi o teste rotacional induzido pela injeção de apomorfina. O teste foi realizado 29 dias após o procedimento cirúrgico. Os dados revelaram mudanças entre os grupos estudados apenas em relação à prática de exercício $[F(3,72)=0,81804 ; \mathrm{p}=0,48811]$, pois o bloqueio do receptor de BDNF não promoveu diferenças no comportamento rotacional $[F(3,72)=96,356 ; p=0,00001]$. Assim, notamos uma piora intensa no comportamento rotacional dos animais sedentários parkinsonianos (ca. 1400\%; SED+DP; SED+DP+K252a, $p=0,000123)$, e menos intensa nos animais parkinsonianos treinados quando comparado ao animal sem a DP (EX+DP - ca. 500\%, p=0,000350; 
$E X+D P+K 252 a-c a .700 \%, p=0,000123)$, e um decréscimo da assimetria rotacional quando comparado ao grupo de sedentários parkinsonianos (EX+DP - ca. 54\%, $\mathrm{p}=0,000123 ; \mathrm{EX}+\mathrm{DP}+\mathrm{K} 252 \mathrm{a}$ - ca. 37\%, $\mathrm{p}=0,002480$ ) (Figura 27) (Tabela 1 apêndice $\mathbf{C}$ ).

Figura 27- Efeitos do treino em esteira antes da indução da DP e do bloqueio do receptor de BDNF sobre o comportamento rotacional induzido por apomorfina em ratos, no 29 dia após a indução do modelo da DP.

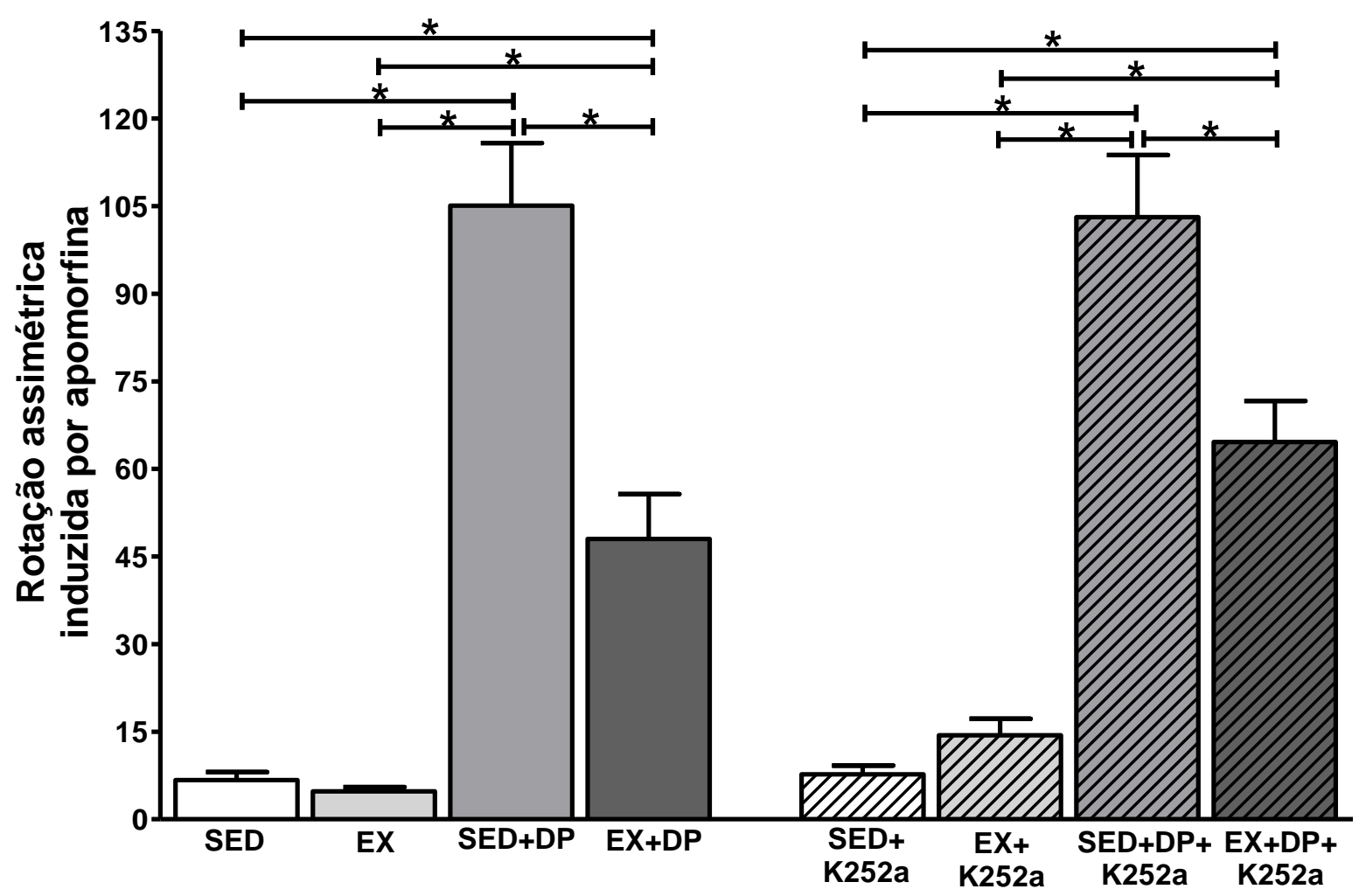

As barras representam a média da rotação assimétrica de cada grupo. Note uma assimetria intensa no comportamento do grupo SED+DP, enquanto o exercício foi capaz de diminuir a disfunção comportamental induzida pela injeção de apomorfina em ratos parkinsonianos. $O$ bloqueio de BDNF não promoveu mudanças na assimetria dos animais. ${ }^{*} \mathrm{p}<0.05$. 


\subsubsection{BDNF}

Os dados de BDNF referem-se à análise realizada no $7^{\circ}$ dia após 0 procedimento cirúrgico através da técnica de dosagem por ELISA (SNc - n=5/grupo e $\mathrm{CPu}$ - $\mathrm{n}=3$ /grupo). Os dados revelaram uma maior expressão de BDNF no CPu, em relação à $S N c[F(1,24)=73,596 ; P=0,000001]$, sem alterações nos níveis de expressão entre os grupos após a injeção de 6-OHDA $[F(3,8)=0,62927 ; p=0,61629]$. Já na SNc notamos um aumento aproximado de 15\% na expressão da neurotrofina do grupo SED+DP em relação aos outros grupos (SED, $p=0,000525$; EX, $p=0,006029 ; E X+D P, p=0,003594)[F(3,16)=10,748 ; p=0,00041]$ (Figura 28) (Tabela 2 - apêndice $C)$.

Figura 28 - Efeitos do treino em esteira antes da indução da DP sobre a expressão de BDNF na SNc e no CPu, no $7^{\circ}$ dia após a indução do modelo da DP.

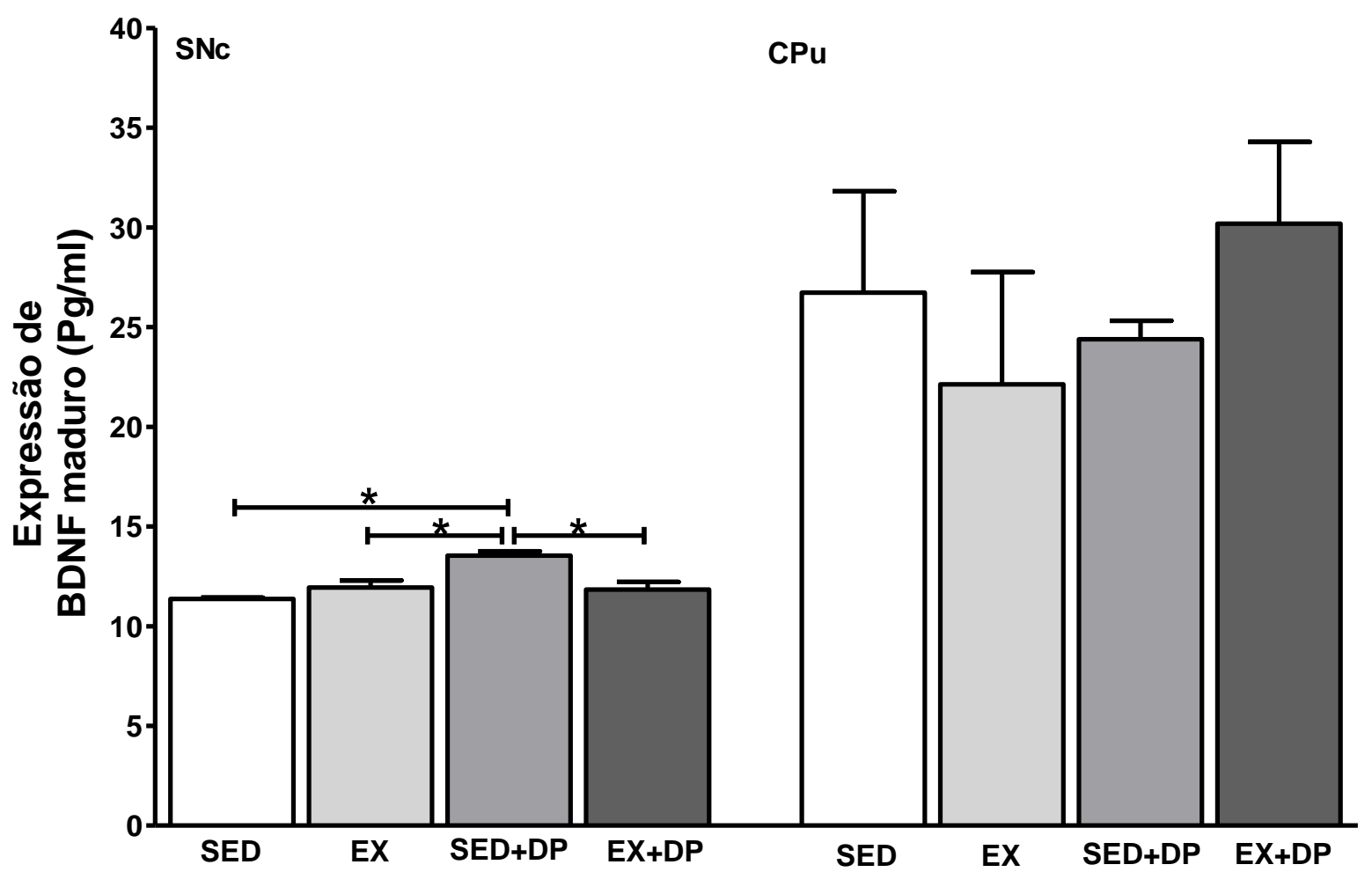

As barras representam a média de expressão de BDNF dosado pela técnica de ELISA. Note que os níveis de BDNF se alteraram apenas na SNc. Esta estrutura revelou um aumento na expressão de BDNF no grupo SED+DP, enquanto o exercício manteve os níveis de expressão semelhantes aos de animais não parkinsonianos. ${ }^{*} p<0,05$. 


\subsubsection{Marcadores de neuroinflamação}

Neste item iremos descrever os dados das análises dos marcadores de processos neuroinflamatórios, sendo eles DHE, iNOS (óxido nítrico sintetase induzível), OX42 (ativação microglial) e GFAP (proliferação astroglial) Esta análise foi realizada no $7^{\circ}$ dia pós-operatório em todos os grupos. Os dados referemse às técnicas de imuno-histoquímica ( $n=3 / g r u p o$ ) e/ou immunoblotting ( $n=5 / g r u p o$ ) (tabela 3, apêndice C).

\subsubsection{Participação das espécies reativas derivadas de oxigênio (DHE)}

A análise da geração de espécies reativas derivado do estresse oxidativo intracelular foi realizada através da técnica da fluorescência da DHE. Os dados obtidos revelaram um aumento na porcentagem de núcleos fluorescentes na SNc do grupo SED+DP em relação aos demais grupos estudados (SED - ca.41\%, $\mathrm{p}=0,001806 ; \mathrm{EX}$ - ca. 30\%, p=0,006305; $E X+D P$ - ca. 45\%, $\mathrm{p}=0,001244$ ) [F(3,8)(Figura 29), enquanto no CPu este aumento ocorreu apenas ao compararmos o grupos SED+DP com o grupo EX+DP (ca. 38\%, $p=0,024616$ ) $[F 3,8)=5,1749$; $\mathrm{p}=0,02806$ ] (Figura 30) (Figura 31) (Tabela 2 - apêndice C). 
Figura 29 - Efeitos do treino em esteira antes da indução da DP sobre a fluorescência da DHE na SNc, no $7^{\circ}$ dia após a indução do modelo da DP.

\section{DHE - SNc}

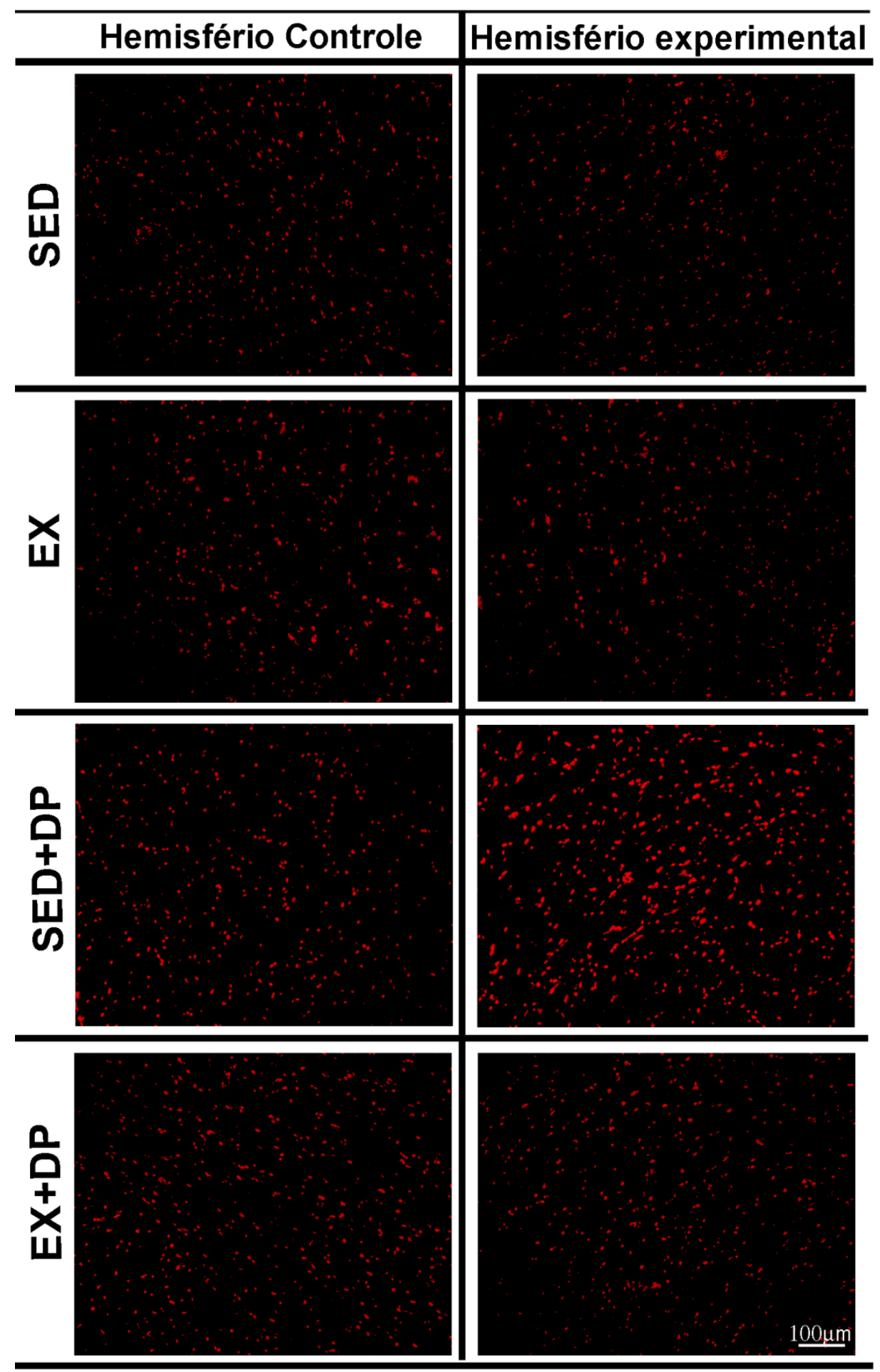

Imagens digitais de cortes coronais da SNc fluorescentes para DHE. Bregma aproximado, $+5,2 \mathrm{~mm}$. Note que há um aumento de núcleos DHE-positivos no grupo SED+DP. Por outro lado, o exercício físico foi capaz de prevenir a geração de espécies reativas de oxigênio após a indução da DP. 
Figura 30 - Efeitos do treino em esteira antes da indução da DP sobre a fluorescência da DHE no $\mathrm{CPu}$, no $7^{\circ}$ dia após a indução do modelo da DP.

\section{DHE - CPu}

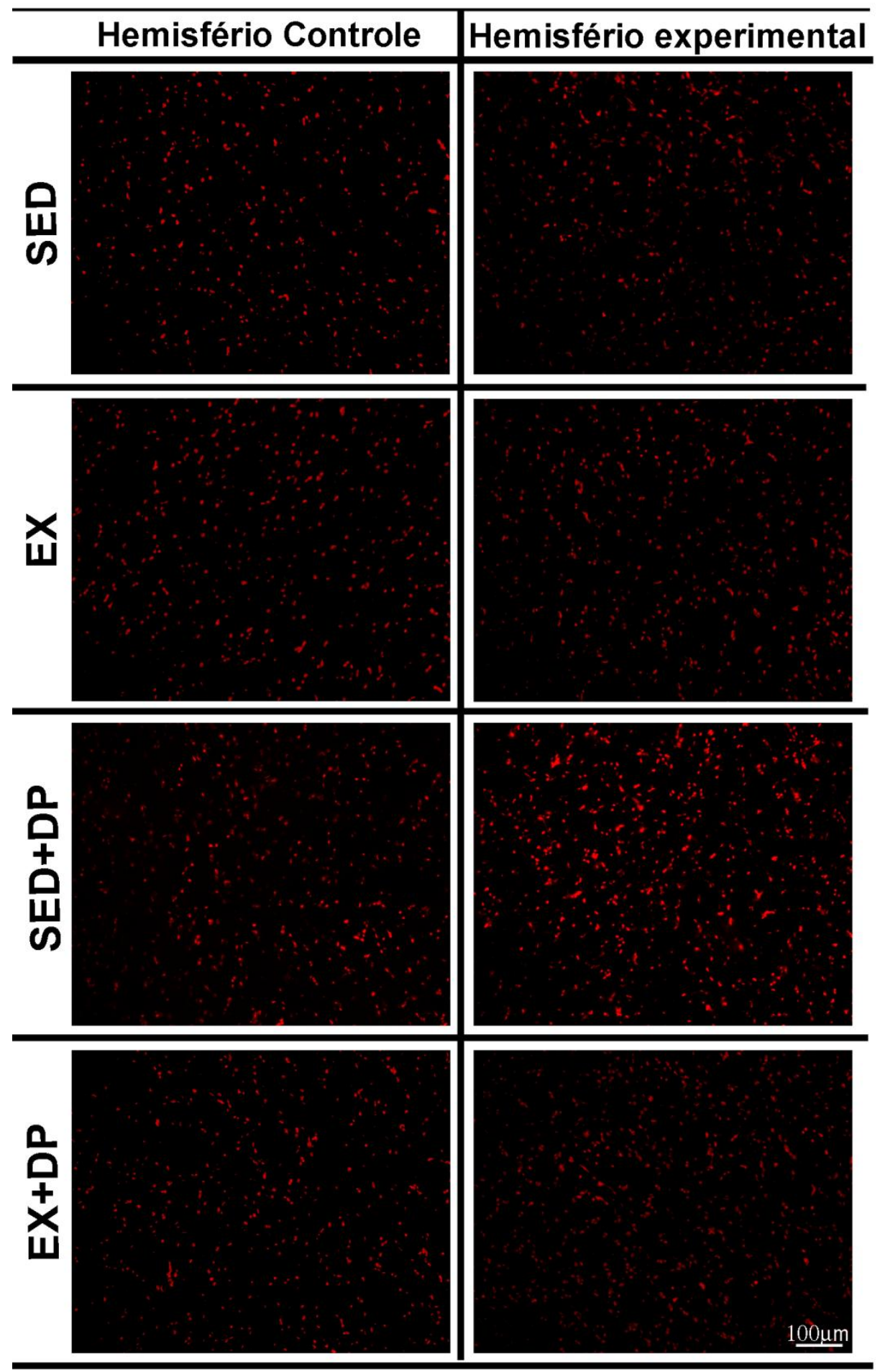

Imagens digitais de cortes coronais do CPu fluorescentes para DHE. Bregma aproximado, $+1,56 \mathrm{~mm}$. Note que há um aumento no número de núcleos DHE-positivas no grupo SED+DP. Por outro lado, o exercício físico foi capaz de prevenir a geração de espécies reativas de oxigênio após a indução da DP. 
Figura 31 - Efeitos do treino em esteira antes da indução da DP sobre a expressão de DHE na SNc e no CPu, no 7º dia após a indução do modelo da DP.

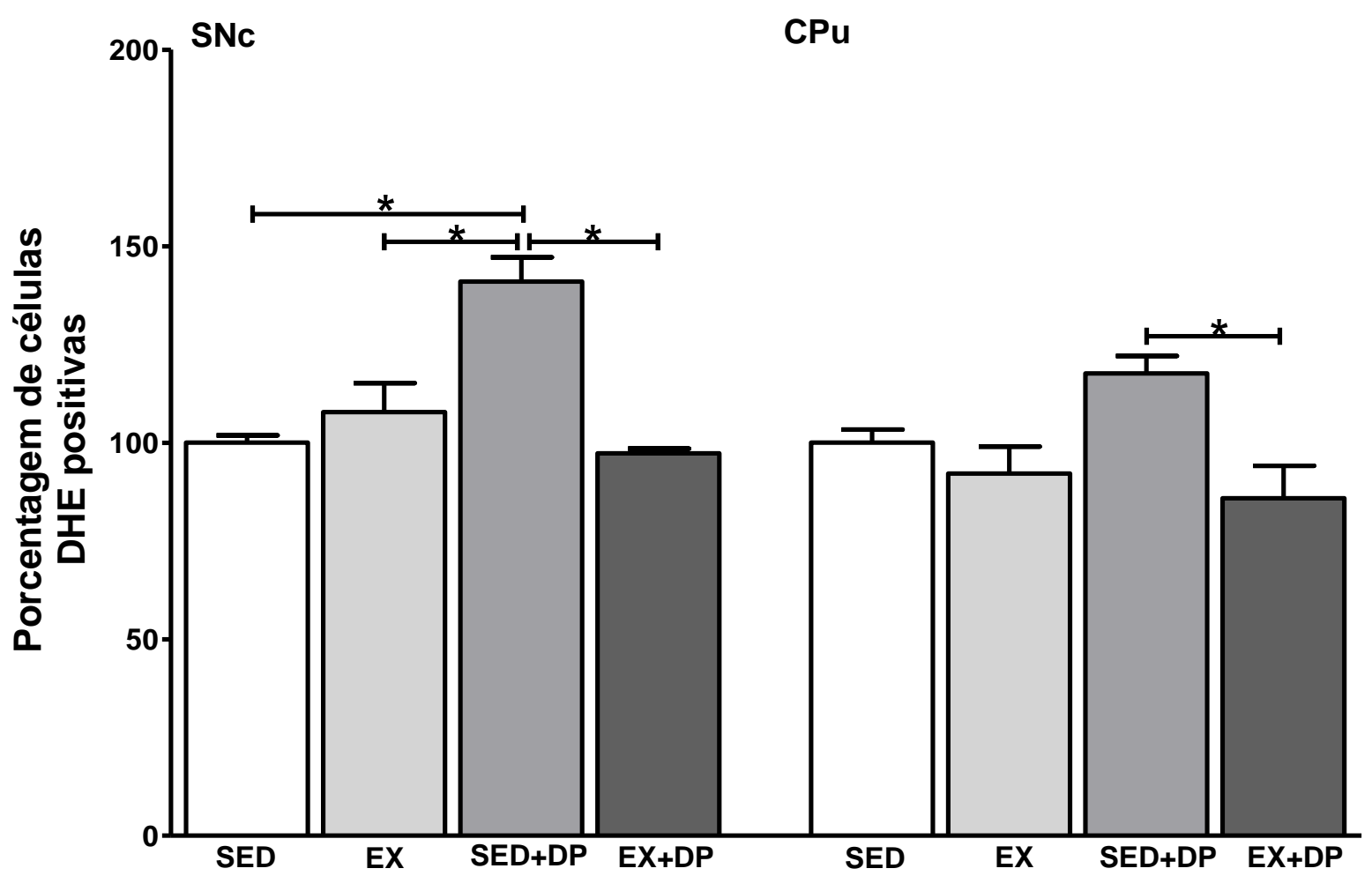

As barras representam a porcentagem de núcleos DHE-positivas no hemisfério experimental em relação ao hemisfério controle na SNc e no $\mathrm{CPu}$. Note um aumento da porcentagem de núcleos marcados no grupo SED+DP, enquanto o exercício é capaz de inibir a geração de EROs. ${ }^{*} \mathrm{p}<0.05$;

\subsubsection{2 iNOS}

Os dados da expressão da enzima iNOS referem-se apenas à análise pela técnica de immunoblotting ( $n=5 /$ grupo). Os resultados revelaram um aumento intenso nos níveis relativos desta proteína na SNc no grupo SED+DP quando comparados aos outros grupos (SED - ca. $200 \%$; EX - ca. $125 \%$; EX+DP - ca. $43 \%$, $p=0,000187) \quad[F(3,16)=59,190 ; p=0,00001]$, e menos intenso no grupo $E X+D P$ quando comparado ao grupo SED (ca. 73\%, p=0,001883). No CPu, notamos um aumento apenas no grupo SED+DP quando comparado aos outros grupos do estudo, sendo menos intenso em relação ao observado na SNc (SED - ca.99\%, p= 0,000627; EX - ca. 67\%, p=0,003566; $E X+D P$ - ca. 89\%, $p=0,000924)$ $[F(3,16)=11,726 ; p=0,00026]$ (Figura 32) (Tabela 3 - apêndice $C$ ). 
Figura 32 - Efeitos do treino em esteira antes da indução da DP sobre a expressão de iNOS na SNc e no CPu, no $7^{\circ}$ dia após a indução do modelo da DP.
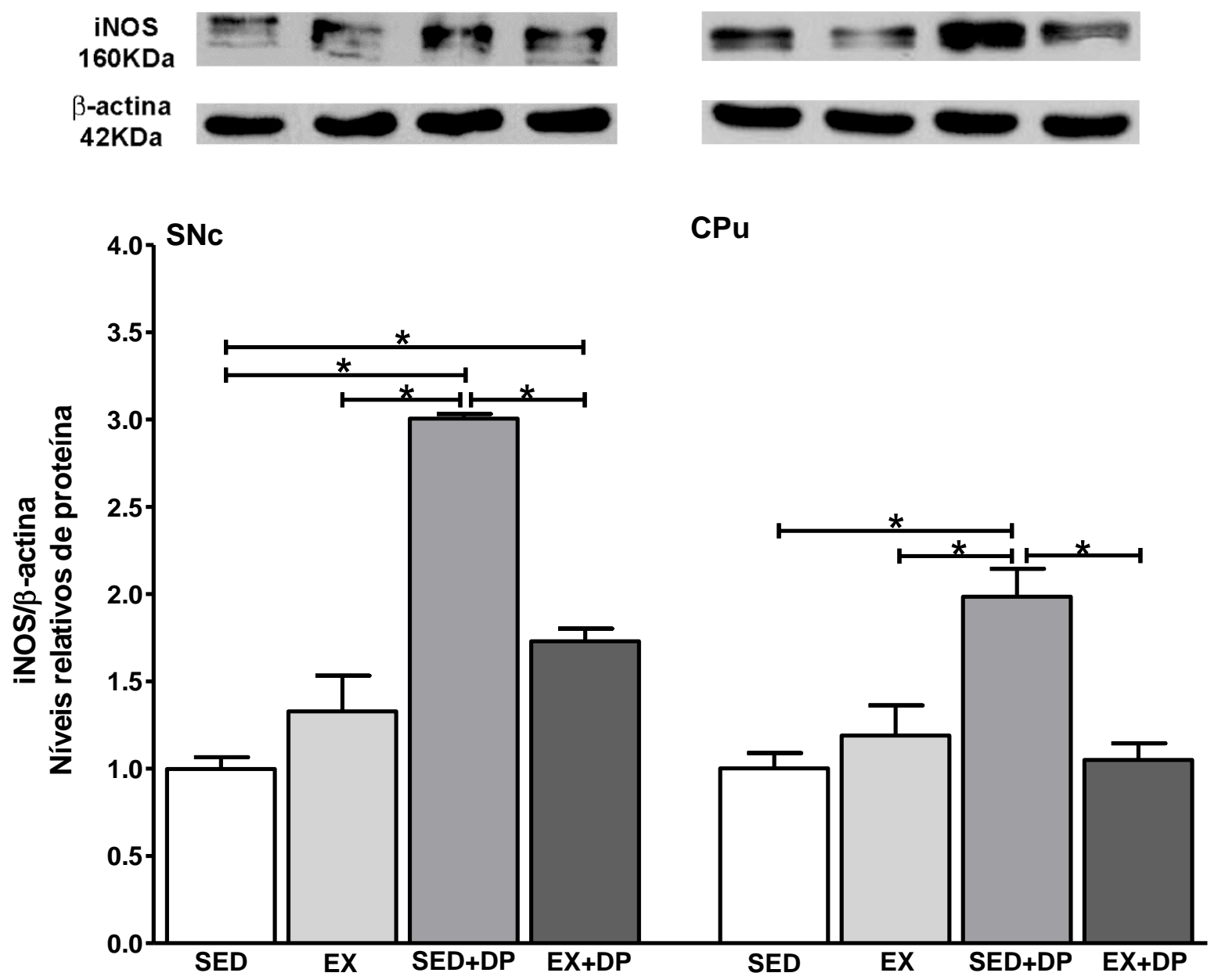

As barras representam a média da razão da densidade óptica entre GFAP e beta-actina, comparando os hemisférios experimentais de cada grupo. A imagem representa bandas típicas de immunoblots para cada condição experimental. Note que os níveis de iNOS aumenta intensamente na SNc e no CPu no grupo SED+DP. Por outro lado, o exercício é capaz de diminuir este efeito. ${ }^{*} \mathrm{p}<0.05$. 


\subsubsection{OX42}

Os dados da marcação de OX42 referem-se apenas aos dados obtidos por imuno-histoquímica, pois não conseguimos uma marcação adequada para esta proteína pela técnica de immunoblotting.

Imagens digitais da SNc representadas na Figura 33 ilustram que não houve diferença da densidade óptica para a marcação de microglia entre os grupos $[F(3,8)=0,93822 ; p=0,46609]$. Por outro lado, no $\mathrm{CPu}$, ilustrado na Figura 34, notamos uma ativação microglial intensa no grupo SED+DP quando comparado aos grupos não parkinsonianos (SED - ca. 35\%, $p=0,019191$; $E X-27 \%, P=0,045323$ ) $[F(3,8)=5,8645 ; p=0,02033]$ (Figura 35) (Tabela 3 - apêndice $C$ ) 
Figura 33 - Efeitos do treino em esteira antes da indução da DP sobre a expressão de OX42 na SNc, no $7^{\circ}$ dia após a indução do modelo da DP.

\section{OX42 - SNc}

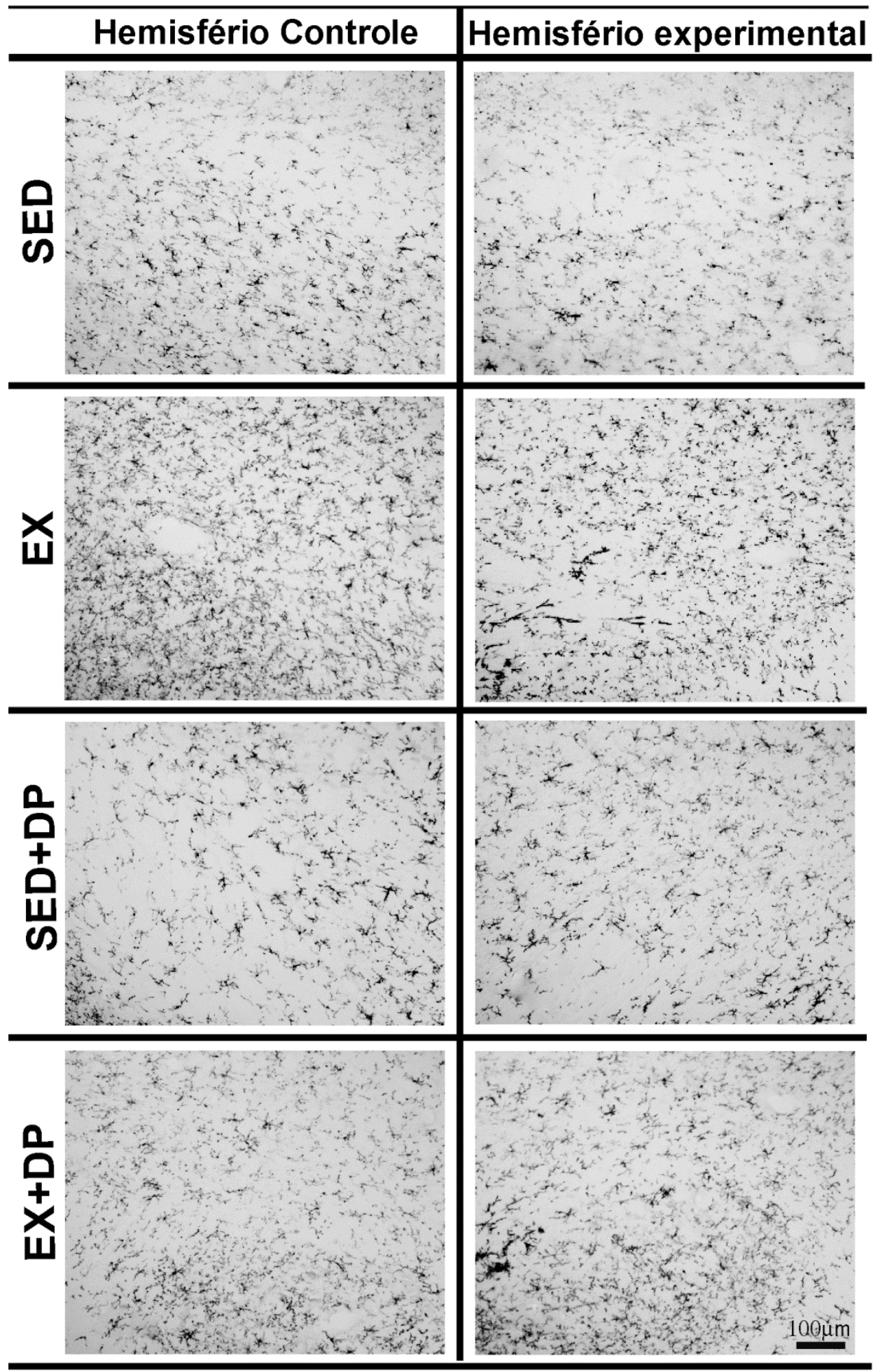

Imagens digitais de cortes coronais da SNc marcados para OX42. Bregma aproximado, $+5,2 \mathrm{~mm}$. Note que não houve ativação microglial 7 dias após o procedimento cirúrgico em nenhum dos grupos estudados. 
Figura 34 - Efeitos do exercício em esteira sobre a expressão de OX42 no $\mathrm{CPu}$, no $7^{\circ}$ dia após a indução do modelo da DP.

\section{$\mathrm{OX} 42-\mathrm{CPu}$}

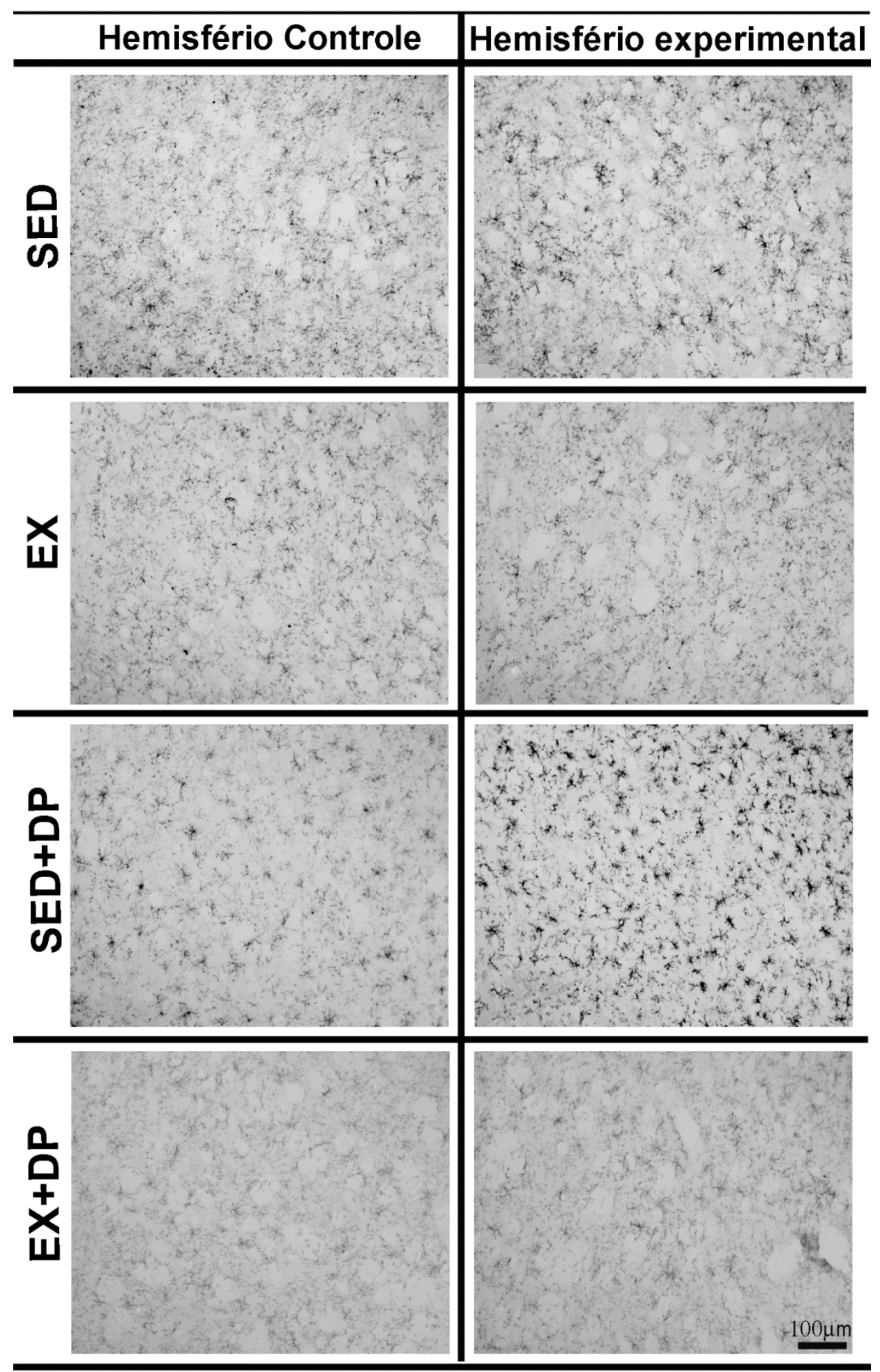

Imagens digitais de cortes coronais do CPu marcados para OX42. Bregma aproximado, $+1,56 \mathrm{~mm}$. Note que há um aumento na expressão de OX42 no grupo SED+DP. Por outro lado, o exercício físico foi capaz de prevenir a proliferação microglial após a indução da DP. 
Figura 35 - Efeitos do treino em esteira antes da indução da DP sobre a expressão de OX42 na SNc e no CPu, no $7^{\circ}$ dia após a indução do modelo da DP.

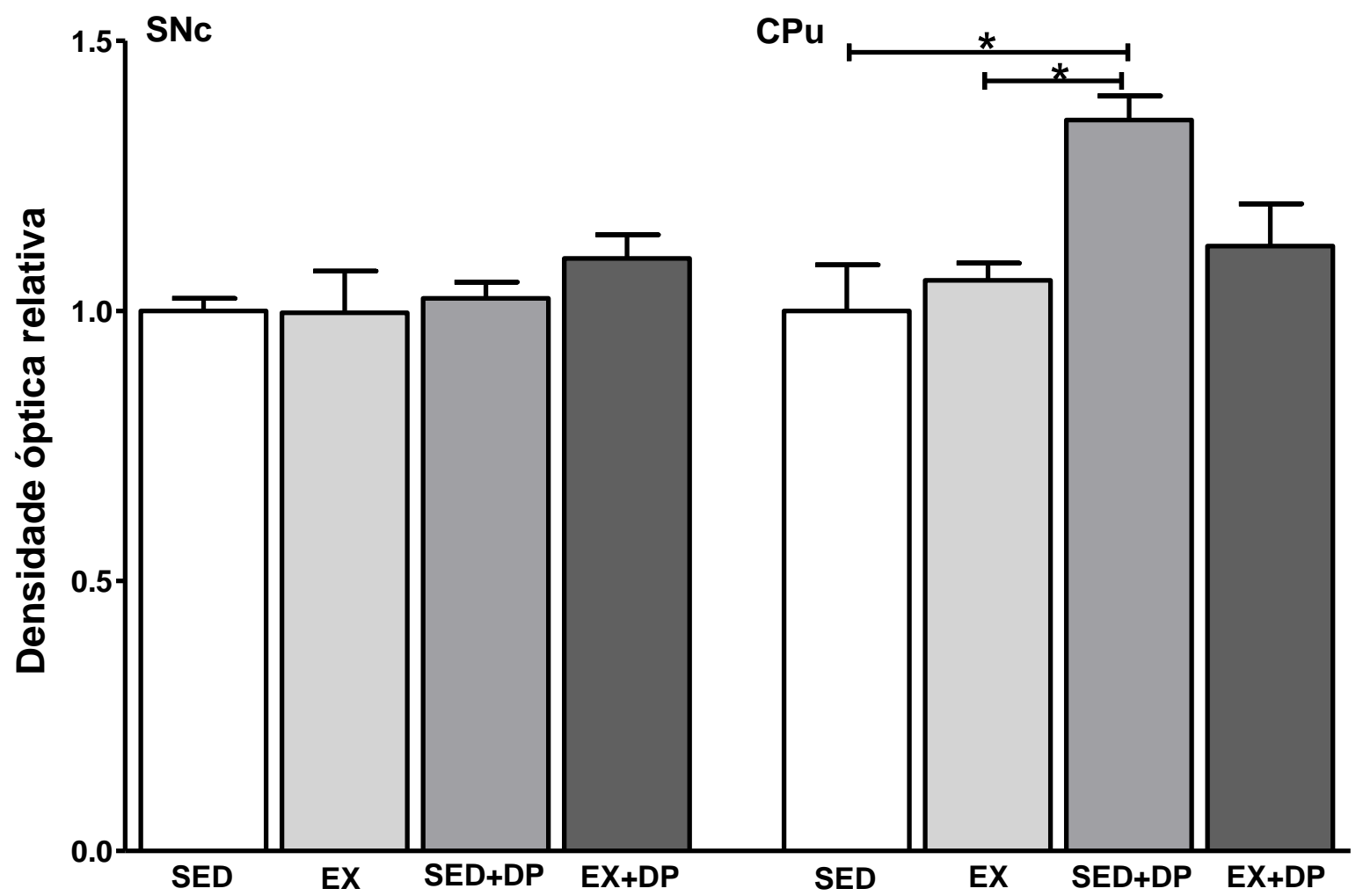

As barras representam a razão da densidade óptica de células microgliais no hemisfério experimental em relação ao hemisfério controle. Note um aumento na densidade no grupo SED+DP, sugerindo ativação microglial, comum em respostas neuroinflamatórias. Por outro lado, o exercício preveniu a ativação, mantendo os níveis semelhantes aos dos animais não parkinsonianos. ${ }^{*} \mathrm{p}<0,05$. 


\subsubsection{GFAP}

Ambas as estruturas analisadas revelaram intensa proliferação astrocitária no grupo SED+DP, como ilustrado nas imagens digitais da Figura 36 e 38. Na SNc, a técnica de imuno-histoquímica ( $\mathrm{n}=3 /$ grupo) (Figura 37A) revelou um acréscimo de $100 \%$ em relação aos ratos não parkinsonianos (SED, $p=0,000233$; $E X$, $\mathrm{p}=0,000257$ ). O grupo $E X+D P$ apresentou um acréscimo de $50 \%$ em relação ao grupo SED ( $p=0,007508)$, ou seja, um descréscimo da proliferação se comparado ao grupo SED+DP (ca. 35\%, $p=0,000608$ ) $[F(3,8)=52,692 ; p=0,00001]$. Por outro lado, a técnica de immunoblotting ( $\mathrm{n}=5 / \mathrm{grupo}$ ) (Figura 37B) demonstrou que houve um aumento aproximado de $100 \%$ apenas no grupo SED+DP quando comparado a todos os outros grupos (SED, $p=0,000186$; $E X, p=0,000188$; $E X+D P, p=0,000193$ ) $[F(3,16)=28,947 ; p=0,000001]$.

No $\mathrm{CPu}$, os resultados foram semelhantes, porém nesta estrutura não houve proliferação no grupo EX+DP. A proliferação astroglial foi intensa no grupo SED+DP em ambas as técnicas e em relação a todos os grupos analisados. \{imunohistoquímica - $[F(3,8)=18,146 ; p=0,00063], S E D$, ca. $73 \%, p=0,003598$, EX, ca. $108 \%, p=0,001073, E X+D P$, ca. $96 \%, p=0,001424$ \} (Figura 38 e 39A) e \{immunoblotting $-[F(3,16)=86,121 ; p=0,000001]$, SED, ca. $134 \%$, EX, ca. $116 \%$, $E X+D P$, ca. 146\%; $p=0,000185\}$ (Figura 39B) (Tabela 3, apêndice C). 
Figura 36 - Efeitos do treino em esteira antes da indução da DP sobre a expressão de GFAP na SNc, no $7^{\circ}$ dia após a indução do modelo da DP.

\section{GFAP - SNc}

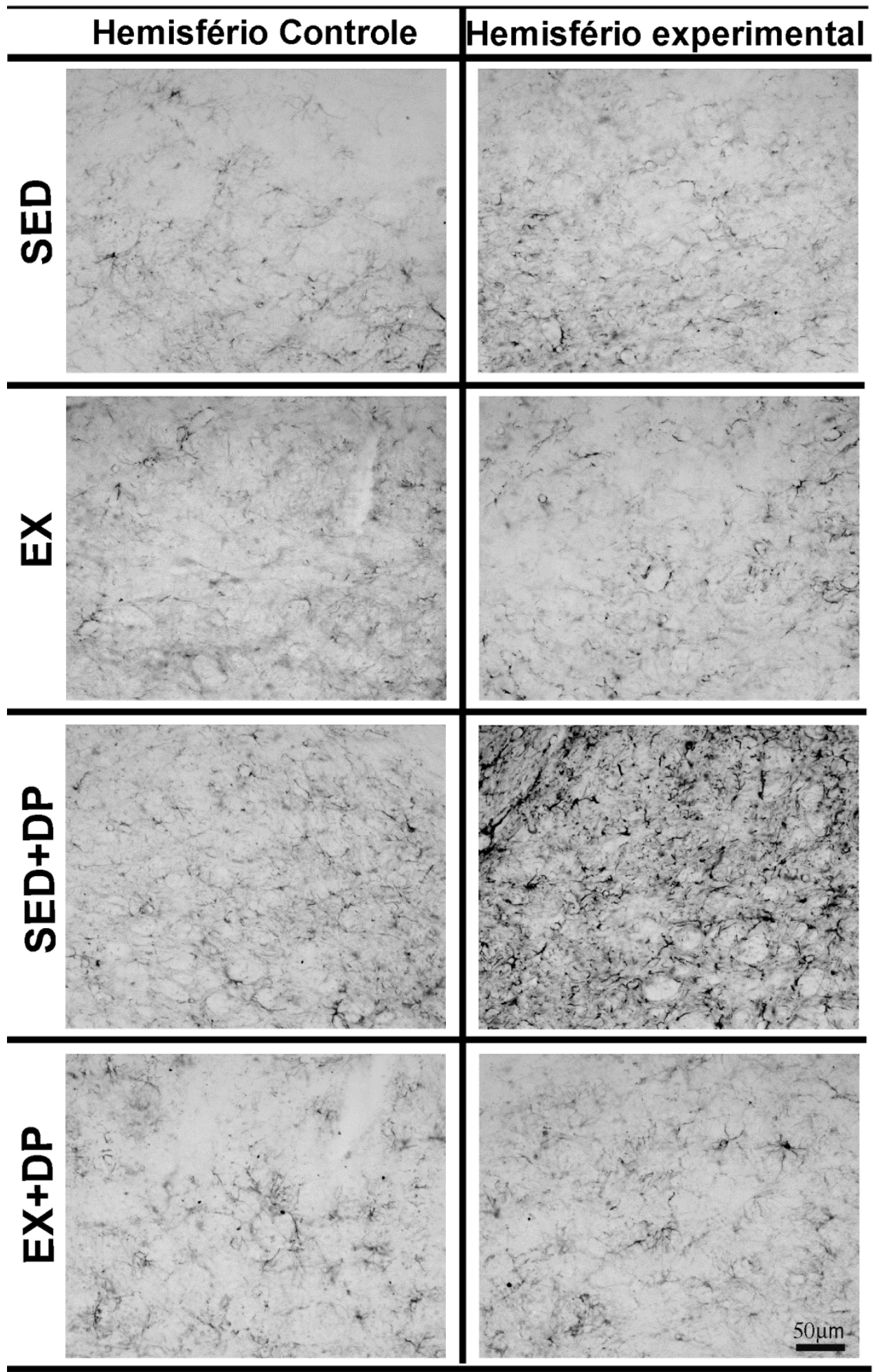

Imagens digitais de cortes coronais da SNc marcados para GFAP. Bregma aproximado, $+5,2 \mathrm{~mm}$. Note uma proliferação astrocitária nos grupos parkinsonianos; porém o exercício foi capaz de diminuir a proliferação. 
Figura 37 - Efeitos do treino em esteira antes da indução da DP sobre a expressão de GFAP na SNc, no $7^{\circ}$ dia após a indução do modelo da DP.
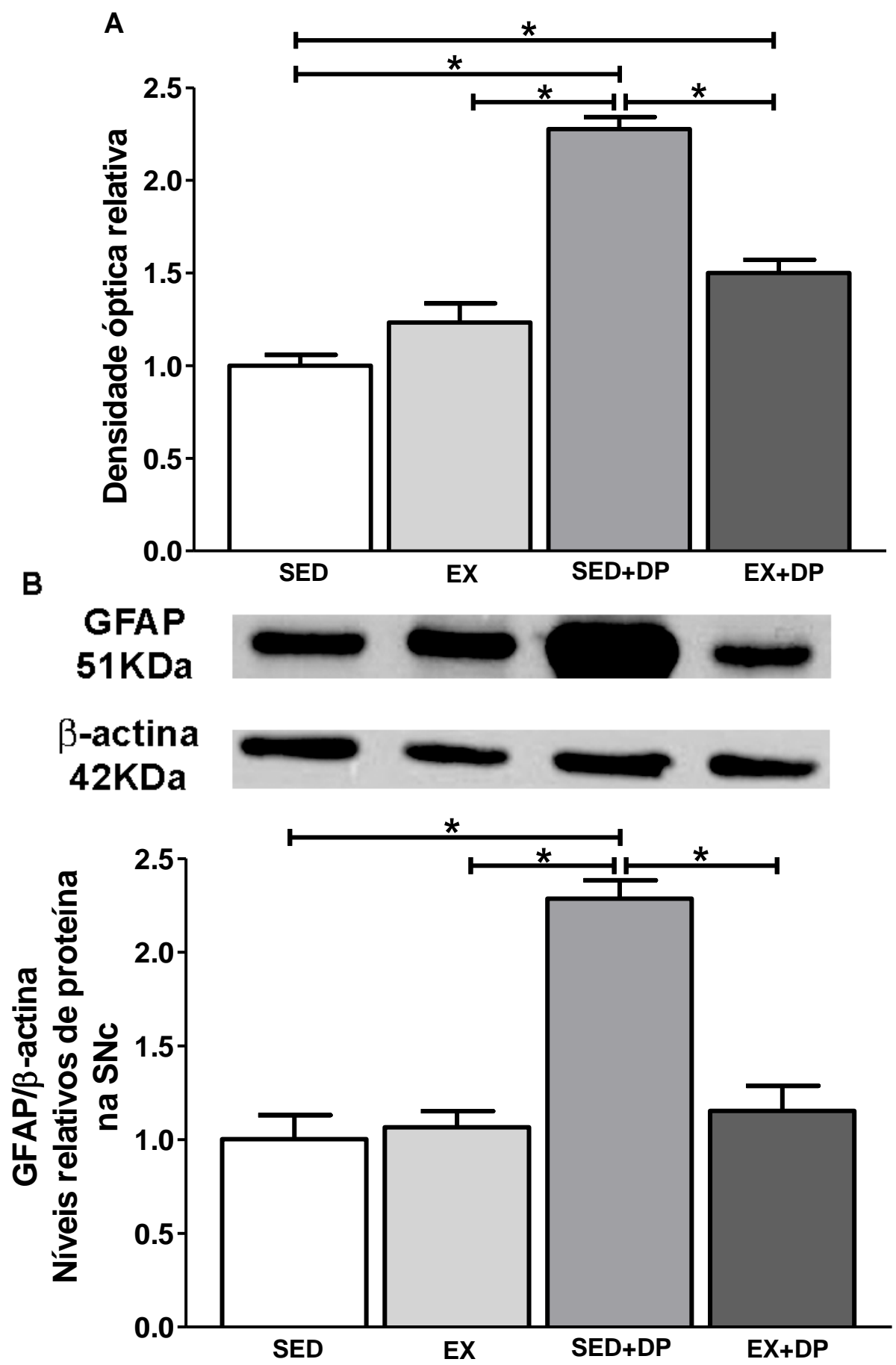

A - as barras representam a média da razão da densidade óptica relativa entre a expressão de GFAP no hemisfério experimental e o hemisfério controle. Note uma intensa proliferação no grupo SED+DP, e menor no grupo EX+DP; $\mathbf{B}$ - as barras representam a média da razão da densidade óptica entre GFAP e beta-actina, comprando os hemisférios experimentais de cada grupo. A imagem representa bandas típicas de immunoblots para cada condição experimental. Note que os níveis de GFAP na SNc aumentam apenas no grupo SED+DP; ${ }^{*} \mathrm{p}<0.05$. 
Figura 38 - Efeitos do treino em esteira an tes da indução da DP sobre a expressão de GFAP no CPu, no $7^{\circ}$ dia após a indução do modelo da DP.

\section{GFAP - CPu}



Imagens digitais de cortes coronais do CPu marcados para GFAP. Bregma aproximado, $+1,56 \mathrm{~mm}$. Note que há um aumento na expressão de OX42 no grupo SED+DP. Por outro lado, o exercício físico foi capaz de prevenir a proliferação astrocitária após a indução da DP. 
Figura 39 - Efeitos do treino em esteira antes da indução da DP sobre a expressão de GFAP no CPu, no $7^{\circ}$ dia após a indução do modelo da DP.

A



B GFAP 51 KDa

$\beta$-actina 42KDa

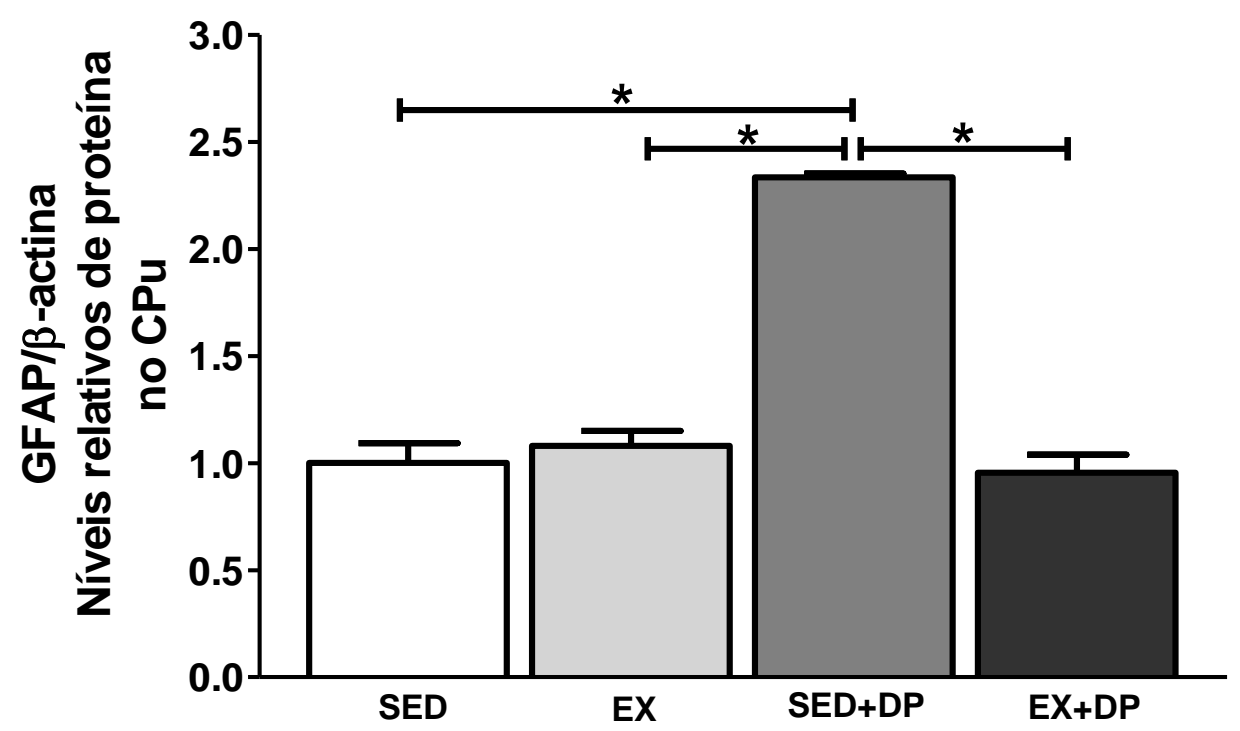

A - as barras representam a média da razão da densidade óptica relativa entre a expressão de GFAP no hemisfério experimental e o hemisfério controle. Note uma intensa proliferação no grupo SED+DP, e menor no grupo EX+DP; $\mathbf{B}$ - as barras representam a média da razão da densidade óptica entre GFAP e beta-actina, comprando os hemisférios experimentais de cada grupo. A imagem representa bandas típicas de immunoblots para cada condição experimental. Note que os níveis de GFAP na SNc aumentam apenas no grupo SED+DP; ${ }^{*} \mathrm{p}<0,05$. 


\subsubsection{TH}

Os dados de $\mathrm{TH}$ referem-se às análises realizadas nos animais 7 e 30 dias após o procedimento cirúrgico através das técnicas de imuno-histoquímica e immunoblotting. A descrição será realizada por estruturas. Vale lembrar que na anáise realizada depois de 30 dias da cirurgia temos os dados do efeito do bloqueio do receptor de BDFN por K252a.

Em todos os grupos estudados, notamos uma marcação de TH em corpos celulares e arborização dendrítica na SNc, enquanto no $\mathrm{CPu}$ a marcação foi evidenciada em terminais de neurônios dopaminérgicos. Os resultados revelaram diferenças no número de células TH-positivas na $\mathrm{SNc}$, na densidade óptica da expressão de TH no CPu, e nos níveis de desta proteína entre os grupos estudados, como veremos adiante.

\subsubsection{Substância negra pars compacta}

$\mathrm{Na}$ SNc, 7 dias após a cirurgia, notou-se uma diminuição de aproximadamente 39\% na porcentagem de células TH-positivas no grupo SED+DP quando comparado ao demais grupos $(p=0,005533)[F(3,8)=11,498 ; p=0,00285]$ (Figura 40 e 41A). Por outro lado, a análise por immunoblotting revelou diminuição nos níveis relativos de proteína em ambos os grupos que receberam 6-OHDA em relação aos grupos que receberam apenas injeção de salina (SED+DP - ca. 53\%, $\mathrm{p}=0,000228$ (SED) e $\mathrm{p}=0,000461$ (EX); $E X+D P$ - ca. $31 \%, p=0,007362$ (SED) e $p=0,041709(E X))[F(3,16)=16,536 ; p=0,00004]$ (Figura 41B e Tabela 3 - apêndice C).

Após 30 dias do procedimento cirúrgico, notamos uma diminuição na porcentagem de células $\mathrm{TH}$-positivas no grupo EX+DP e uma queda mais acentuada no grupo SED+DP em relação ao $7^{\circ}$ dia. Assim, no $30^{\circ}$ dia há uma queda de $72 \%$ no grupo SED+DP e de 47\% no grupo EX+DP em relação aos grupos de ratos não parkinsonianos (SED e EX; $p=0,000138$ ). Desta forma, a porcentagem de células TH-positivas no grupo EX+DP é cerca de $90 \%$ maior em relação ao grupo SED+DP ( $p=0,000296)$, sugerindo uma proteção das células dopaminérgicas. Por outro lado, a adição do bloqueador de BDNF, K252a, inibe o efeito prototetor promovido pelo 
exercício e a porcentagem de morte celular é semelhante aos animais dos grupos SED+DP e SED+DP+K252a, ou seja, diminui cerca de 70\% a marcação de $\mathrm{TH}$ em células dopaminérgicas em relação aos grupos não parkinsonianos que receberam K252a ( $p=0,000138)$, e cerca de $50 \%$ em relação ao grupo EX+DP $(0,000317)$ $[F(3,32)=7,8137 ; p=0,00047]$ (Figura 42 e 43A). Os dados de immunoblotting no $30^{\circ}$ dia revelaram uma melhora nos níveis de $\mathrm{TH}$ na SNc do grupo EX+DP, ficando com níveis semelhantes aos de animais não parkinsonianos, enquanto o grupo SED+DP manteve a diminuição dos níveis em relação aos outros grupos (ca. 50\%, $\mathrm{p}=0,000173$ ). O bloqueio do receptor pela adição de K252a revelou resultados que corroboram os dados da imuno-histoquímica, ou seja, diminuição de cerca de $60 \%$ nos níveis de TH nos animais que receberam a injeção de 6-OHDA, ou seja, $S E D+D P+K 252 a$ e $E X+D P+K 252 a(p=0,000141)$, anulando assim a prevenção promovida pelo exercício $[F(3,32)=20,432 ; p=0,000001]$ (Figura 43B) (Tabela 1 apêndice $\mathrm{C}$ ). 
Figura 40- Efeitos do treino em esteira antes da indução da DP sobre a expressão de TH na SNc, no $7^{\circ}$ dia após a indução do modelo da DP.

\section{Tirosina Hidroxilase - SNc}
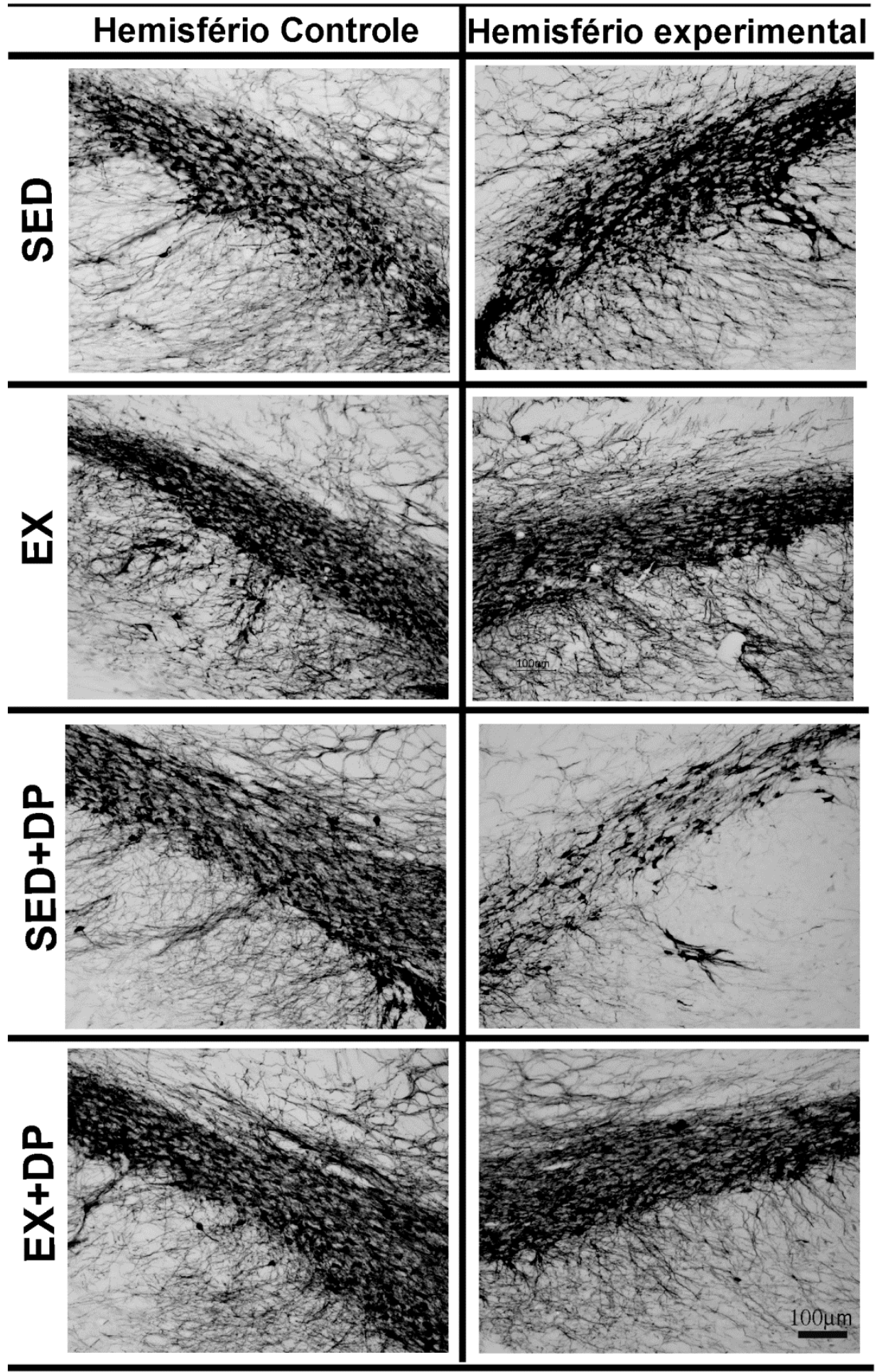

Imagens digitais de cortes coronais da SNc marcados para TH. Bregma aproximado, $+5,2 \mathrm{~mm}$. Note que 7 dias após a indução da DP já ocorre uma redução na expressão de TH no grupo SED+DP, porém, o exercício foi capaz de prevenir a perda de neurônios dopaminérgicos induzida pela injeção de 6-OHDA. 
Figura 41 - Efeitos do treino em esteira antes da indução da DP sobre a expressão de TH na SNc, no $7^{\circ}$ dia após a indução do modelo da DP.
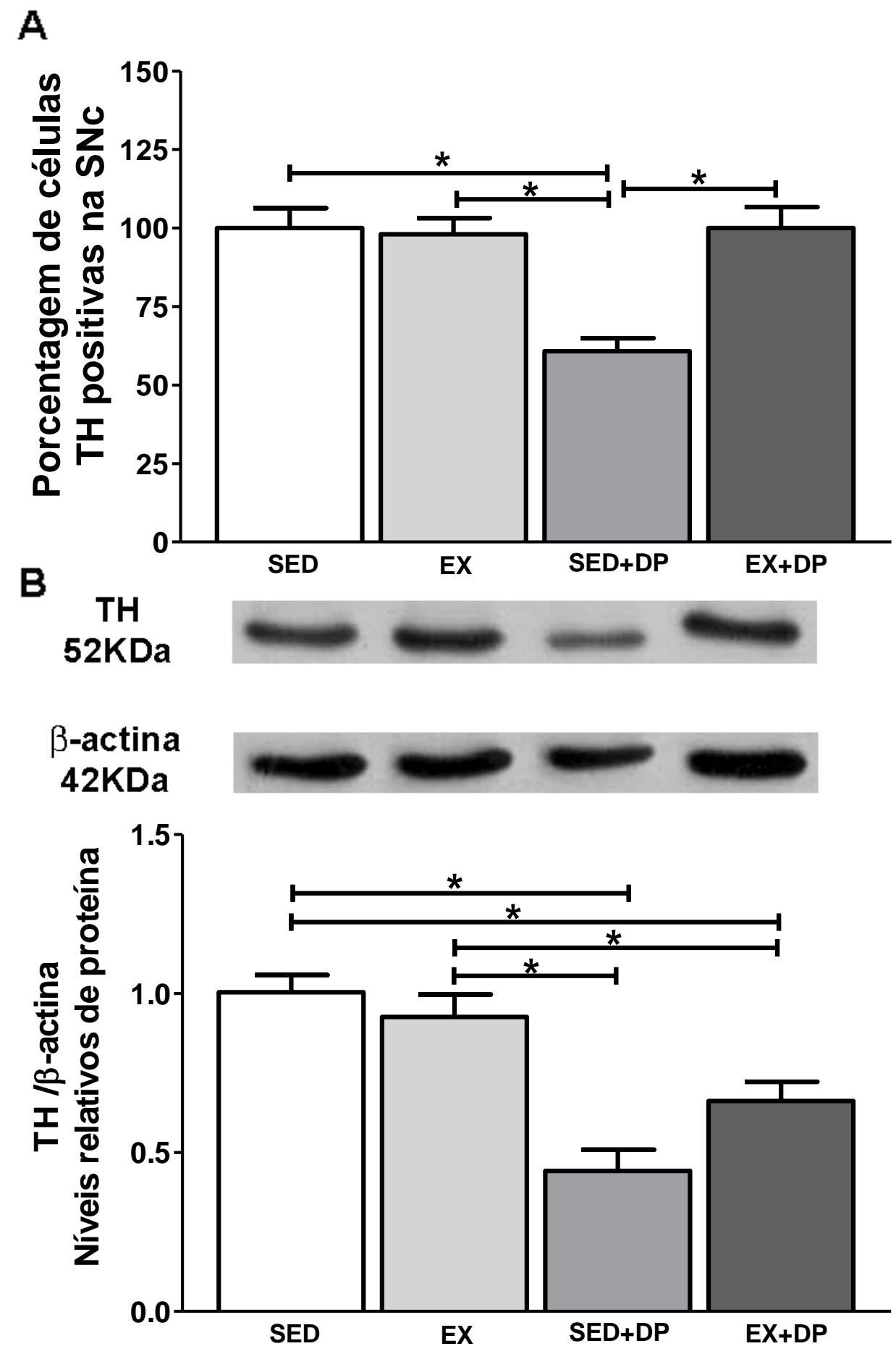

A - as barras representam a média da razão da densidade óptica relativa entre a expressão de GFAP no hemisfério experimental e o hemisfério controle. Note uma intensa proliferação no grupo SED+DP, e menor no grupo EX+DP; $\mathbf{B}$ - as barras representam a média da razão da densidade óptica entre GFAP e beta-actina, comprando os hemisférios experimentais de cada grupo. A imagem representa bandas típicas de immunoblots para cada condição experimental. Note que os níveis de GFAP na SNc aumentam apenas no grupo SED+DP; ${ }^{*} \mathrm{p}<0.05$. 
Figura 42 - Efeitos do treino em esteira antes da indução da DP e do bloqueio de receptor de BDNF sobre a expressão de TH na SNc, no 30 dia após indução do modelo da DP.

\section{Tirosina Hidroxilase - SNc}

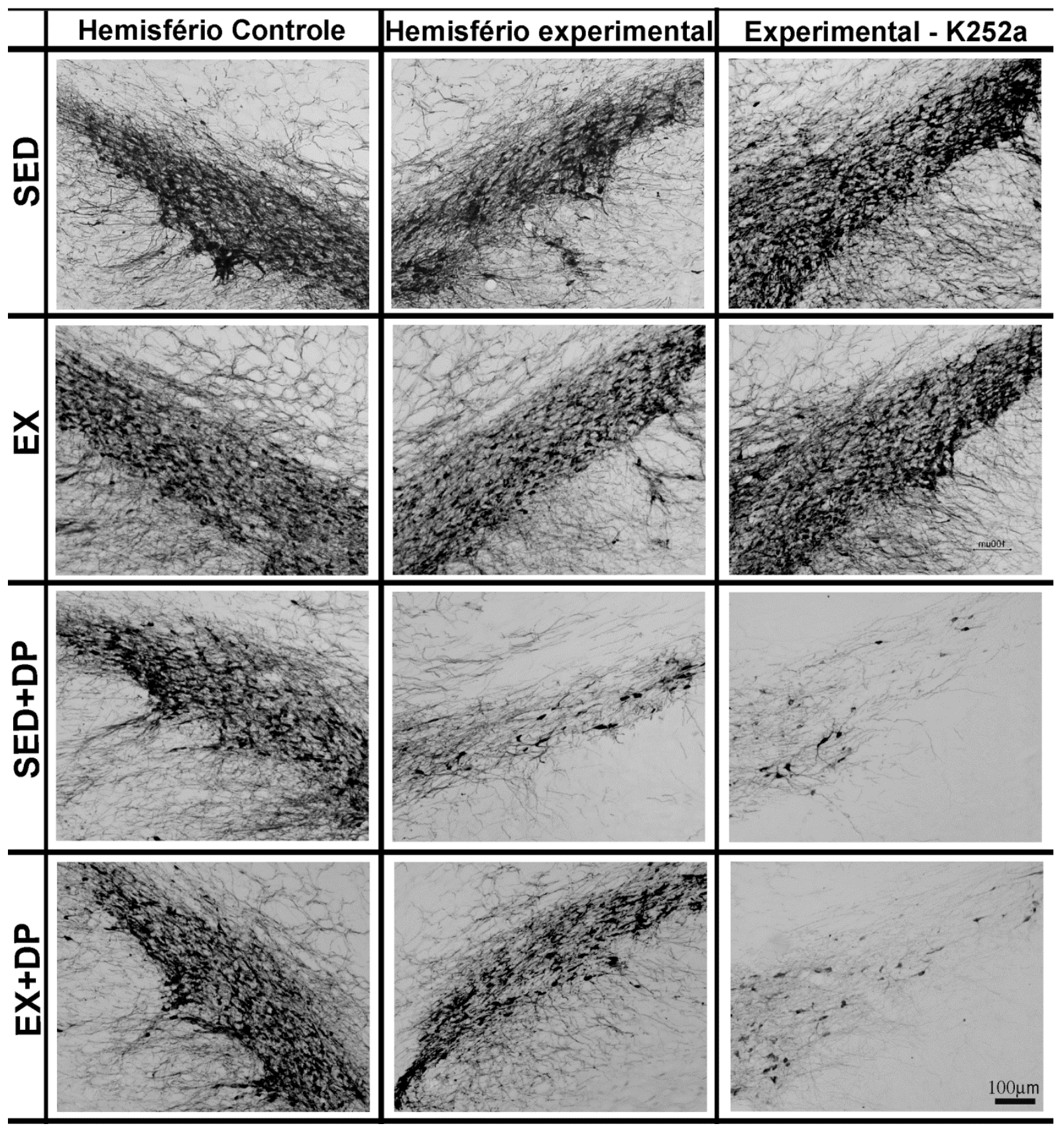

Imagens digitais de cortes coronais da SNc marcados para TH. Bregma aproximado, $+5,2 \mathrm{~mm}$. Note que 7 dias após a indução da DP já ocorre uma redução na expressão de TH no grupo SED+DP, porém, o exercício foi capaz de prevenir a perda de neurônios dopaminérgicos induzida pela injeção de 6-OHDA. O bloqueio do receptor de BDNF, K252a, reverte o efeito protetor do exercício contra a perda de neurônios dopaminérgicos induzida pela injeção de 6-OHDA. 
Figura 43 - Efeitos do treino em esteira antes da indução da DP e do bloqueio de receptor de BDNF sobre a expressão de TH na SNc, no $30^{\circ}$ dia após indução do modelo da DP.

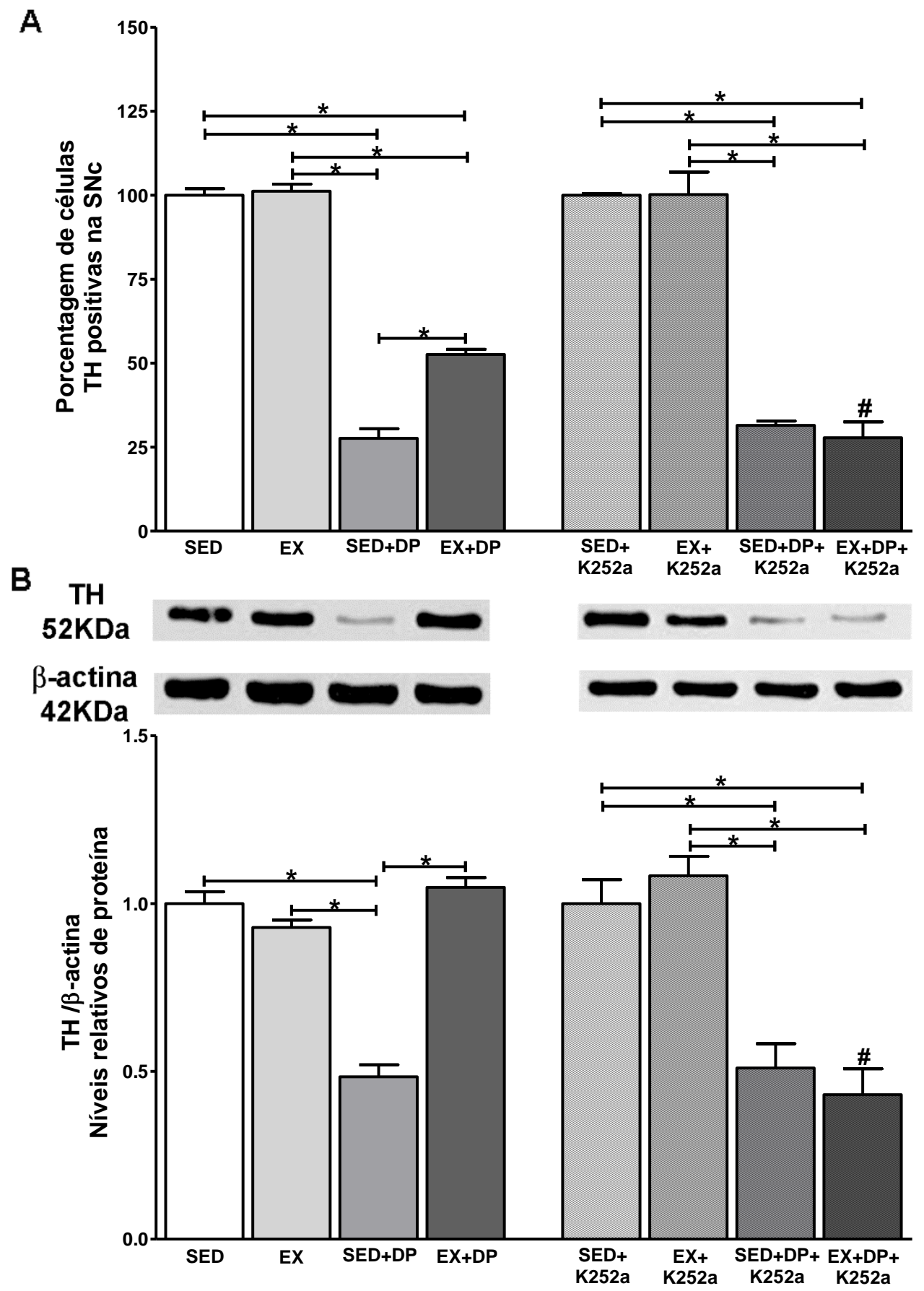

A - as barras representam a porcentagem de células TH-positivas no hemisfério experimental em relação ao hemisfério controle. $\mathbf{B}$ - as barras representam a média da razão da densidade óptica entre $\mathrm{TH}$ e beta-actina, comparando os hemisférios experimentais de cada grupo. A imagem representa bandas típicas de immunoblots para cada condição experimental. O bloqueio do receptor de BDNF, K252a, reverte o efeito protetor do exercício contra a perda de neurônios dopaminérgicos induzida pela injeção de 6-OHDA. ${ }^{*} \mathrm{p}<0.05$; \# indica significância entre o grupo que recebeu K252a e seu correspondente que não recebeu a droga bloqueadora do receptor de BDNF. 


\subsubsection{Estriado}

A análise de $\mathrm{TH}$ no $\mathrm{CPu}$ revelou resultados semelhantes aos encontrados na SNc, ou seja, déficits de TH mais intensos no grupo SED+DP. No $7^{\circ}$ dia após a cirurgia houve uma queda de $25 \%$ na densidade óptica relativa para $\mathrm{TH}$ no CPu em relação aos outros grupos (SED - $p=0,010407$; EX - 0,030374; EX+DP - 0,01120) $[F(3,8)=8,5869 ; p=0,00698]$ (Figura 44 e 45A). A técnica de immunoblotting, além de demonstrar a queda nos níveis de TH no grupo SED+DP em relação aos animais do grupo SED e EX (ca. 81\%, $p=0,000185$ ), revelou uma queda no grupo $E X+D P$, que não foi detectado pela densidade óptica relativa na técnica de imuno-histoquímica (ca. $51 \%, p=0,000389$ ). Porém, os níveis expressos no grupo $E X+D P$ continua sendo maior em relação ao grupo SED+DP (ca. 160\%, p=0,007892) $[F(3,16)=49,559 ; p=0,000001]$ (Figura 45B) (Tabela 3 - apêndice C).

No $30^{\circ}$ dia após a cirurgia, os animais do grupo SED+DP acentuaram a perda de terminações dopaminérgicas no $\mathrm{CPu}$ em relação aos animais dos grupos SED e EX (ca. $50 \%, p=0,000138$ ), com 7 dias a perda foi de $25 \%$ e no 30 - dia de $50 \%$. Os animais do grupo EX+DP mantiveram a expressão semelhante aos animais sem a DP. Por outro lado, ao adicionarmos K252a, os animais do grupo EX+DP também apresentaram densa perda de terminações dopaminérgicas em relação aos animais não parkinsonianos (SED+K252a e EX+K252a - ca. 25\%, p=0,000138) e ao grupo $E X+D P$ (ca. 19\%, $p=0,000518)[F(3,32)=9,0533 ; p=0,00017]$ (Figura 46 e 47A).

O mesmo resultado de immunoblotting que obtivemos para a SNc encontramos no CPu, ou seja, o grupo SED+DP continuou com intensos déficits de TH em relação aos outros grupos (ca. $50 \%, p=0,000138$ ), enquanto o grupo EX+DP apresentou um acréscimo nos níveis de TH em relação ao $7^{0}$ dia (ca. 93\%), ficando semelhante aos grupos SED e EX. Por outro lado, ao adicionarmos o K252a, como demonstrado pela imuno-histoquímica, obtivemos uma queda nos níveis relativos de TH no grupo EX+DP+K252a (ca. 70\%, $p=0,000138$ ), e não apenas no grupo SED+DP+K252a (ca. 65\%, p=0,000138) em relação aos grupos SED+K252a e EX+K252a. Notamos então uma queda de $65 \%$ ao bloquearmos o receptor de BDNF nos animais do grupo EX+DP $(p=0,000138)[F(3,32)=27,791 ; p=0,000001]$ (Figura 47B) (Tabela 1 - apêndice $C$ ). 
Figura 44 - Efeitos do treino em esteira antes da indução da DP sobre a expressão de TH no $\mathrm{CPu}$, no $7^{\circ}$ dia após indução do modelo da DP.

\section{Tirosina Hidroxilase - CPu}



Imagens digitais de cortes coronais do CPu marcados para TH. Bregma aproximado, $+1,56 \mathrm{~mm}$. Note uma redução na expressão de TH nos ratos parkinsonianos (SED+DP e $E X+D P)$. 
Figura 45 - Efeitos do treino em esteira antes da indução da DP sobre a expressão de TH no CPu, no $7^{\circ}$ dia após indução do modelo da DP.

A

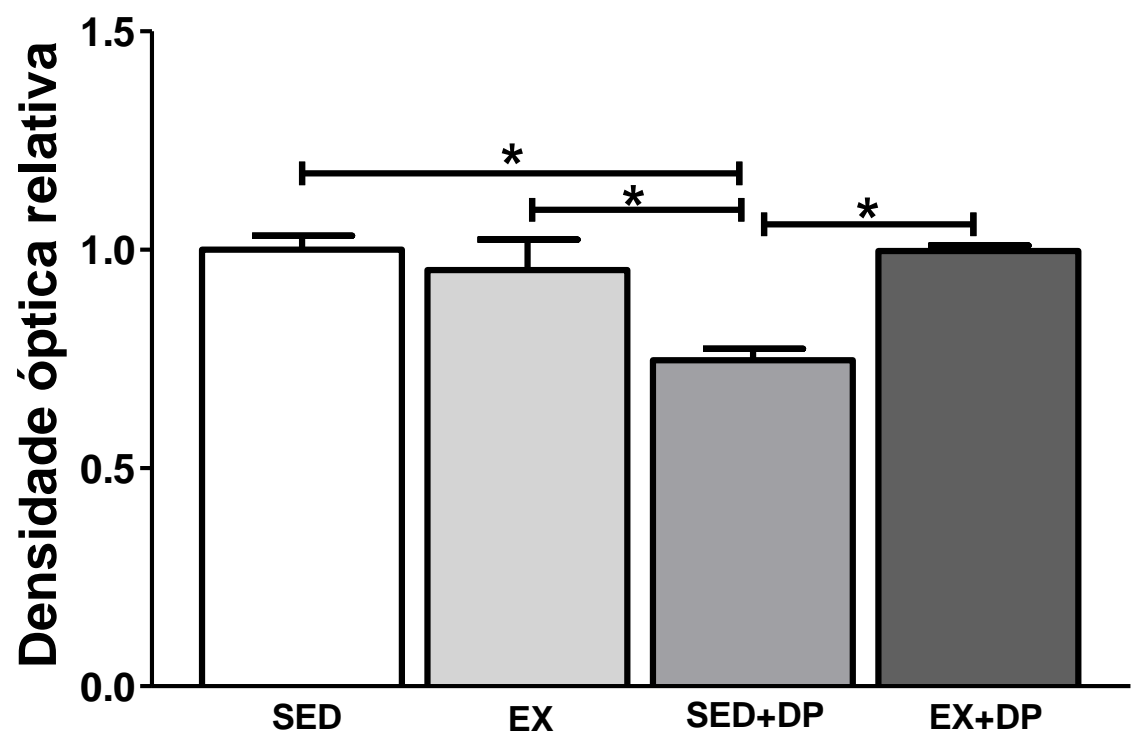

B
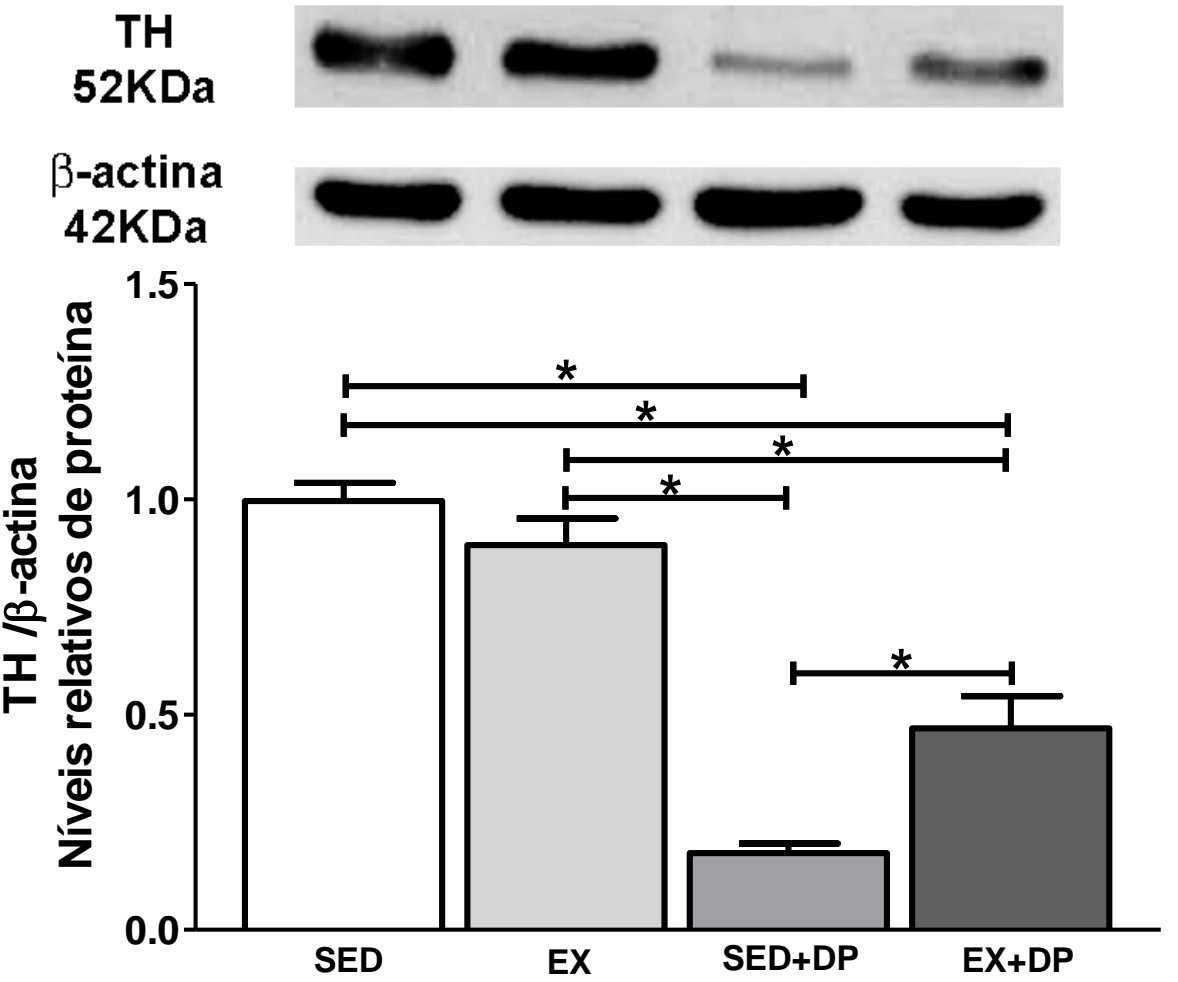

A - as barras representam a média da razão da densidade óptica relativa entre a expressão de TH no hemisfério experimental e o hemisfério controle. Note uma queda na expressão no grupo SED+DP, o que não acontece no grupo EX+DP; $\mathbf{B}$ - as barras representam a média da razão da densidade óptica entre $\mathrm{TH}$ e beta-actina, comparando os hemisférios experimentais de cada grupo, onde podemos observar uma queda da expressão nos grupos SED+DP e EX+DP. A imagem representa bandas típicas de immunoblots para cada condição experimental. * $\mathrm{p}<0.05$. 
Figura 46 - Efeitos do treino em esteira antes da indução da DP e do bloqueio de receptor de BDNF sobre a expressão de $\mathrm{TH}$ no $\mathrm{CPu}$, no $30^{\circ}$ dia após indução do modelo da DP.

\section{Tirosina Hidroxilase - $\mathrm{CPu}$}



Imagens digitais de cortes coronais do $\mathrm{CPu}$ marcados para $\mathrm{TH}$. Bregma aproximado, $+1,56 \mathrm{~mm}$. Note que a redução na expressão de TH observado nos ratos do grupo SED é atenuada após o exercício. O bloqueio do receptor de BDNF, K252a, reverte o efeito protetor do exercício contra a perda de neurônios dopaminérgicos induzida pela injeção de 6-OHDA. 
Figura 47 - Efeitos do treino em esteira antes da indução da DP e do bloqueio de receptor de BDNF sobre a expressão de $\mathrm{TH}$ no $\mathrm{CPu}$, no $30^{\circ}$ dia após indução do modelo da DP.

A

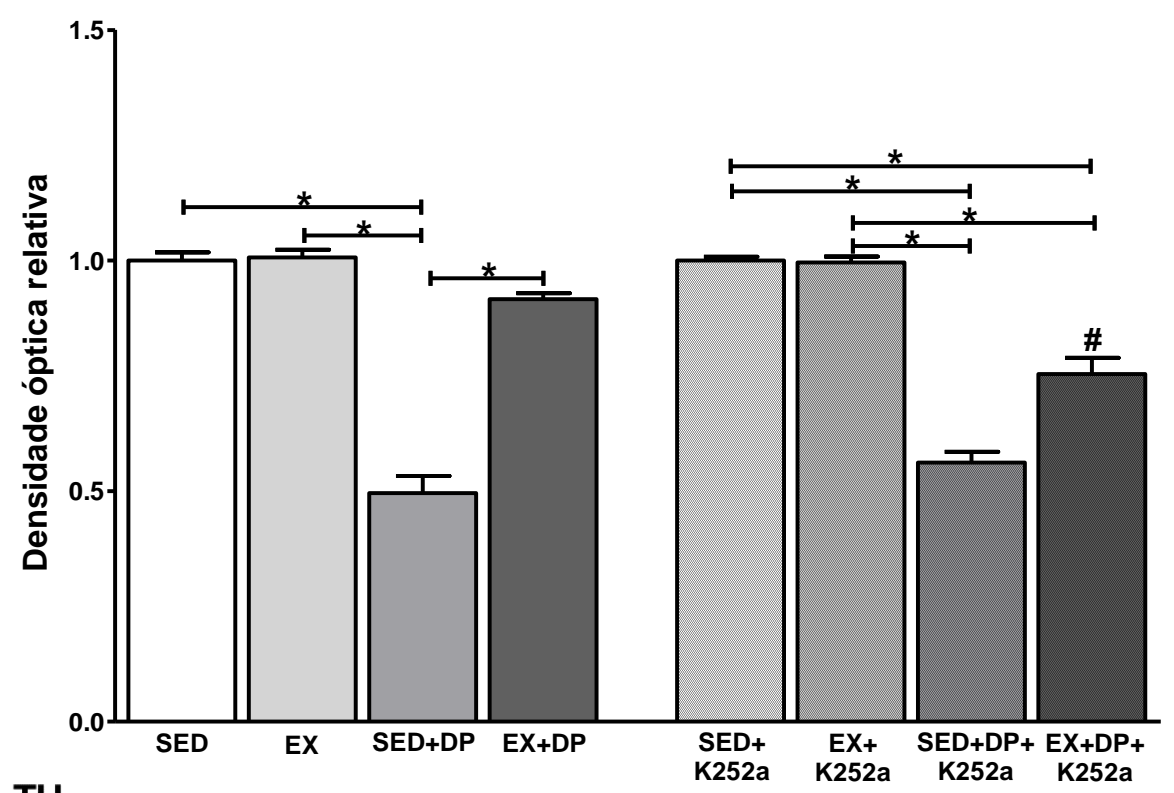

B
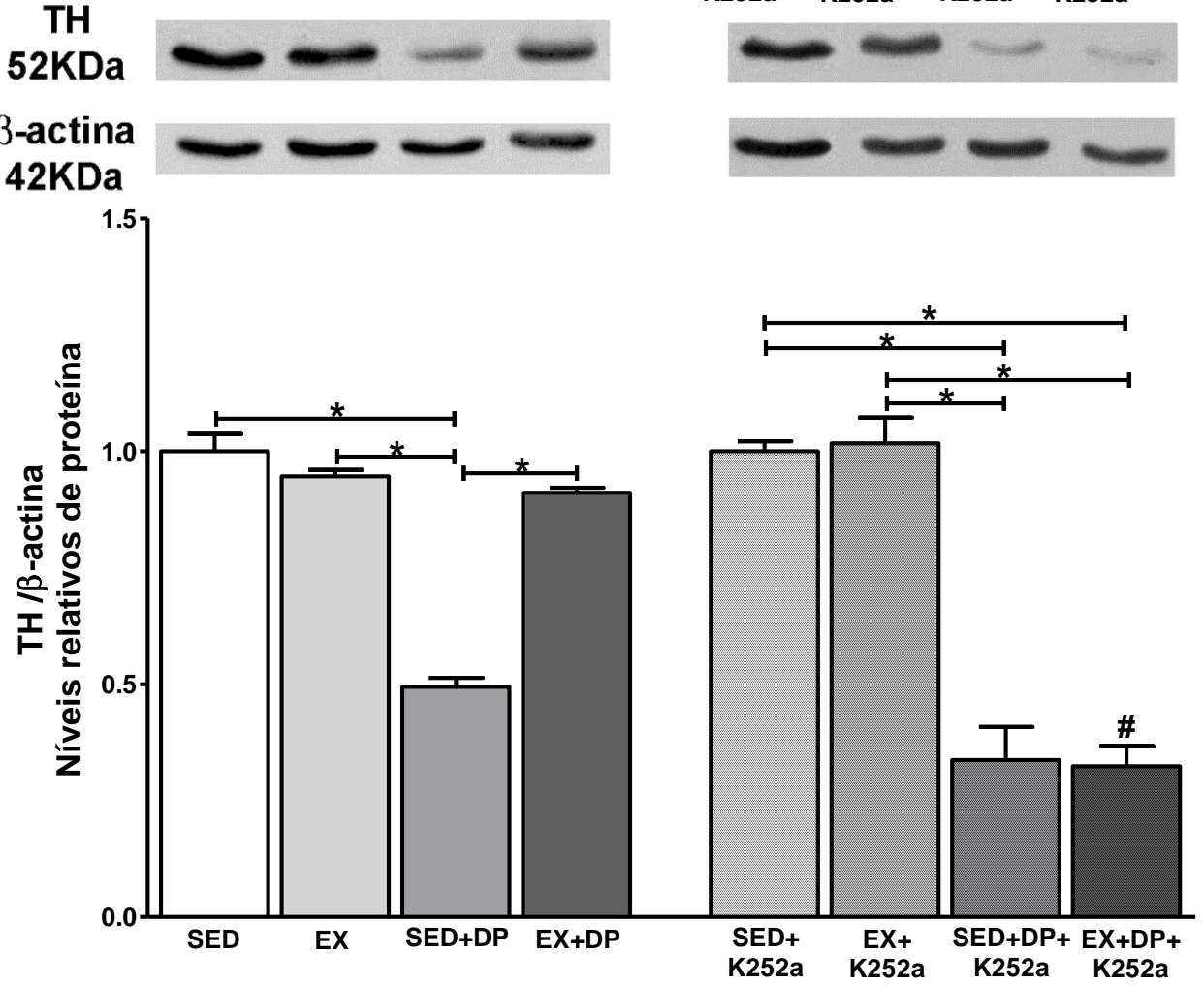

A - as barras representam a porcentagem de células TH-positivas no hemisfério experimental em relação ao hemisfério controle. B - as barras representam a média da razão da densidade óptica entre $\mathrm{TH}$ e beta-actina, comparando os hemisférios experimentais de cada grupo. A imagem representa bandas típicas de immunoblots para cada condição experimental. O bloqueio do receptor de BDNF, K252a, reverte o efeito protetor do exercício contra a perda de neurônios dopaminérgicos induzida pela injeção de 6-OHDA. " $\mathrm{p}<0,05$; \# indica significância entre o grupo que recebeu $\mathrm{K} 252 \mathrm{a}$ e seu correspondente que não recebeu a droga bloqueadora do receptor de BDNF. 


\section{$\underline{5.3 \text { Discussão }}$}

O propósito deste estudo foi investigar o efeito preventivo do protocolo de exercício intermitente em esteira sobre o desenvolvimento do modelo da DP induzida por 6-OHDA. Para isto, analisamos a participação de processos neuroinflamatórios na instalação da doença, como ativação microglial (Wojtera et al., 2005), proliferação astrocitária (Maragakis, Rothstein, 2006; Eng et al., 2000), geração de EROs (Blum et al., 2001; Dexter et al., 1989; Hensley et al., 1998; Mattson et al., 2007) e síntese de NO (Blum et al., 2001; Hunot et al., 1996; Kavya et al., 2006); e o possível envolvimento do BDNF, uma neurotrofina que tem um papel crítico nos mecanismos de neuroproteção induzido pelo exercício (Blum et al., 2001; Mattson, 2008; Nguyen et al. 2009; Tajiri et al., 2010; Zigmond et al., 2009; Wu et al., 2011).

Em geral, o exercício intermitente em esteira empregado neste estudo produziu uma queda na expressão dos marcadores de neuroinflamação no mesmo grupo que apresentou um acréscimo nos níveis de TH, ou seja, no grupo EX+DP; por outro lado o grupo SED+DP apresentou um acréscimo nos níveis de BDNF na SNc e um acréscimo dos marcadores neuroinflamatórios associados a diminuição nos níveis de TH. Por outro lado, o bloqueio do receptor de BDNF com K252a eliminou os efeitos observados nos níveis de TH do grupo EX+DP. Além disso, os dados do teste de rotação induzido por apomorfina corroboram os dados neuroquímicos, ou seja, queda nos níveis de TH e acréscimo nas respostas neuroinflamatórias promoveram maiores déficts motores (aumento da assimetria rotacional) (Henderson et al., 2003; Real et al., 2013; Yoon et al., 2007). Desta forma, parece haver uma importante participação do exercício no controle dos processos neuroinflamatórios, responsáveis pela indução de processos neurodegenerativos (Blum et al., 2001), e consequente diminuição na morte de neurônios dopaminérgicos e melhora comportamental. Os dados referentes à resposta neuroinflamatória foram analisados no $7^{\circ}$ dia pós-operatório, ou seja, momento de intensa ação da neurotoxina (Blandini et al., 2008; Labandeira-Garcia et al., 1996).

Alguns estudos têm elucidado o papel do estresse oxidativo em processos neurotóxicos que levam à morte celular tanto em modelos animais (revisado por 
Blum et al., 2001) quanto em humanos (revisado por Mattson, 2007). É essencial o delicado equilíbrio entre a geração de EROs e a sua decomposição. Níveis elevados de EROs induzem excitotoxicidade secundária, pois aumentam indiretamente os níveis de NO intracelular (revisado por Blum et al., 2001), agravando, facilitando ou mesmo causando doenças neurodegenerativas (revisado por Radák et al., 2008; Radák et al., 2001). Recentemente, Fujita e colaboradores (2009) demonstraram como possível forma de prevenção da DP a associação do fator antioxidante, hidrogênio, na água de beber de camundongos submetidos ao modelo da DP por MPTP. Neste estudo, os animais que beberam água saturada de hidrogênio apresentaram menor perda de neurônios TH-positivos. Associado à diminuição da perda neuronal houve diminuição da fluorescência por DHE.

O exercício moderado é capaz de diminuir a geração de EROs, como observado no hipocampo de ratos idosos (Marosi et al., 2012) e em modelos de epilepsia (Kim et al., 2011). O exercício, em geral, parece ser capaz de alterar o estado antioxidativo e redox do encéfalo (Somani et al., 1996, 1995). Mudanças na produção de EROS após o exercício podem ser importantes no controle do estresse oxidativo (revisado por Radak et al., 2008; Radák et al., 2001), e assim, ser capaz de diminuir a incidência de doenças neurodegenerativas (Holloszy, Kohrt, 1995). Por outro lado, o treino intenso de ratos saudáveis em esteira 1 hora/dia, por 8 semanas, $5 x /$ semana é capaz de aumentar marcadores de EROs em níveis fisiológicos (Radák et al., 2013), parecendo ser essa uma resposta adaptativa aguda que estimula a síntese de enzimas antioxidantes e reparação tecidual, pois não se observam lesões no sistema nervoso após aquele aumento (Radák et al., 2002, 2001). Logo, nosso estudo com o modelo da DP corrobora os estudos anteriores com ratos idosos e epilépticos. Em nosso estudo utilizamos um protocolo de exercício de intensidade moderada, onde notamos uma diminuição na fluorescência da DHE no grupo EX+DP, principalmente na SNc (onde encontramos os corpos celulares das células dopaminérgicas que sofrem degeneração no modelo da DP), sendo o mesmo grupo que apresentou melhora nos níveis de TH e menor assimetria rotacional, ou seja, resultados semelhantes aos encontrados nos grupos de animais não-parkinsonianos. Logo, a perda de neurônios dopaminérgicos pode estar relacionada com o aumento de EROs, ou seja, o desequilíbrio entre fatores oxidantes e antioxidantes, comum em processos neurodegenerativos. Assim, 
podemos sugerir que o protocolo de exercício foi capaz de intervir nos mecanismos de estresse oxidativo, um dos responsáveis pela morte celular em doenças neurodegenerativas (revisado por Radak et al., 2008; Radák et al., 2001).

A síntese de iNOS também parece estar envolvida no desenvolvimento da DP. Esta enzima é capaz de causar um desequilíbrio oxidativo, ou seja, gerar estresse oxidativo (revisado por Koppula et al., 2012) e também está associada a processos degenerativos na SNc (Hunot et al., 1996). Assim, estudos visando regular a síntese desta enzima vêm sendo realizados, e mais uma vez, o exercício tem sido um dos meios de intervenção. O exercício em esteira por 4 semanas no modelo de MPTP revelou queda na expressão de iNOS nos mesmos grupos que apresentaram proteção do sistema dopaminérgico (Sung et al., 2012). Logo, o nosso estudo corrobora este achado, indicando que mesmo sendo realizado antes da indução da DP, existem mecanismos ativos capazes de inibir a síntese de iNOS após a lesão, pois observamos que o grupo EX+DP apresentou menores níveis iNOS em relação ao grupo SED+DP. A inibição da síntese de iNOS, por sua vez, pode ter favorecido a melhora nos níveis de TH e comportamental. Além de estudos com exercício físico, outros estudos focam o bloqueio não seletivo da síntese da enzima NOS (Barthwal et al., 2001), ou seletivo de iNOS (Broom et al., 2011), ou knockout para genes de iNOS (Dehmer et al., 2000), e todos demonstraram proteção dos neurônios dopaminérgicos após indução de modelos da DP. Assim, parece que o controle da síntese de iNOS mediante um estímulo tóxico é essencial para evitar progresso de processos neurodegenerativos. Por conseguinte, nossos dados de diminuição da DHE e iNOS no grupo EX+DP evidenciam que o exercício intermitente em esteira é capaz de modular em níveis adequados as EROs, e consequentemente prevenir o desenvolvimento da DP (revisado por Koppula et al., 2012).

Outro fator que favorece o aumento de radicais livres na degeneração encontrada na DP é a ativação microglial responsável por produzir NO e citocinas, e assim promover um desequilíbrio entre síntese e degradação de EROs, e consequentemente estresse oxidativo (Blum et al., 2001). Nossos achados revelam uma ativação microglial intensa no grupo SED+DP associado à diminuição dos níveis de $\mathrm{TH}$, corroborando os estudos que demonstram interação entre microglia e o desenvolvimento da DP, onde a ativação microglial precede a perda de neurônios 
dopaminérgicos tanto em humanos (Forno et al., $1996^{3}$ apud Marinova-Mutafchieva et al., 2009; Ouchi et al., 2005) quanto em modelos animais (Cichetti et al., 2002; Marinova-Mutafchieva et al., 2009). Estudo com tomografia por emissão de pósitrons (PET) em ratos submetidos ao modelo com injeção intra-estriatal de 6-OHDA revelaram aumento da reatividade para $\left[{ }^{11} \mathrm{C}\right](\mathrm{R})$ - PK11195, um marcador de microglia ativada, seguido por diminuição da reatividade para $\left[{ }^{11} \mathrm{C}\right] \mathrm{CFT}$, um marcador de DAT, além de diminuição da expressão de TH e aumento da expressão de OX42 em análises de imuno-histoquímica (Cichetti et al., 2002). Estudo clínico, com pacientes parkinsonianos, corrobora os dados com animais, ou seja, antes de ocorrer diminuição da ligação de DAT ao radioativo, há uma hiperativação de microglia, reforçando a ideia da participação microglial na progressão da DP (Ouchi et al., 2005). Outro indicio da participação microglial na morte de neurônios dopaminérgicos na DP foi obtido no modelo animal com 6-OHDA. Este estudo relatou que antes de haver diminuição da expressão de $\mathrm{TH}$, há uma intensa proliferação de marcadores microgliais, e assim parece haver uma resposta diretamente proporcional entre a ativação glial e a perda neuronal (MarinovaMutafchieva et al., 2009).

Estudos que correlacionam a ativação microglial com a DP e o exercício físico são controversos. Um deles demonstrou que o exercício em esteira por 4 semanas antes da injeção de LPS diminui a perda de neurônios dopaminérgicos, porém não altera a ativação microglial na SNc (Wu et al., 2011). Por outro lado, um estudo com o modelo de MPTP revelou diminuição da proliferação microglial após 4 semanas de treino em esteira (Sung et al., 2012). O nosso estudo revelou que o exercício foi capaz de promover diminuição da ativação microglial, revelados com diminuição da marcação para OX42, e melhora nos níveis de $\mathrm{TH}$, ainda na fase aguda da instalação da DP, deixando mais forte a evidência da participação da microglia na DP. Logo, nossos dados corroboram um dos estudos (Sung et al., 2012) e contradiz o outro (Wu et al., 2011). Vale ressaltar que os protocolos utilizados por estes estudos para indução do modelo da DP foram distintos, sendo que a injeção intraperitoneal de LPS promove uma rápida inflamação da SNc e em outras regiões do cérebro (Blum et al., 2001), enquanto o nosso modelo com 6-OHDA promove um processo de morte menos agressiva e mais seletiva das células dopaminérgicas

\footnotetext{
${ }^{3}$ Forno LS. Neuropathology of Parkinson's disease. J Neuropathol Exp Neurol. 1996;55:259-72.
} 
(Schober, 2004; Tillerson et al., 2002), assim como no modelo com MPTP. Logo, cada modelo pôde ter ativado mecanismos distintos de morte celular, e consequentemente respostas distintas da microglia.

Além da ativação microglial, estudos relatam aumento da ativação astroglial em modelos animais da DP (Eng et al., 2000), no soro de pacientes com a DP (Su et al., 2012), e na expressão de GFAP na SNc durante o envelhecimento fisiológico, podendo estar diretamente relacionado com a degeneração seletiva de neurônios dopaminérgicos durante a evolução da DP (Venkateshappa et al., 2012), sendo estes mais sensíveis a processos inflamatórios (Wojtera et al., 2005). Parece que a hipersensibilidade glial é responsável pelo aumento do risco de desenvolver algumas doenças neurodegenerativas (Gordon et al., 1997). Nossos dados revelaram que a expressão de GFAP foi semelhante ao encontrado para a ativação microglial, ou seja, uma proliferação intensa no grupo SED+DP, com inibição deste mecanismo nos animais do grupo EX+DP, grupo que manteve os níveis de $\mathrm{TH}$ semelhantes aos ratos não parkinsonianos. Estudos mostram que da mesma forma que ocorre com a ativação microglial, o exercício também é capaz de diminuir a ativação astroglial, em modelos da DP, após treino em esteira, por 4 semanas, 5x/semana. A diminuição na proliferação de astrócitos parece estar envolvida na melhora motora dos animais, tendo em vista que não houve mudanças na expressão de TH quando comparado os animais sedentários com os treinados (Dutra et al., 2012). Logo, parece que o nosso protocolo de exercício foi capaz de modular os mecanismos de astrogliose que podem participar de processos neurodegenerativos, e assim prevenir o desenvolvimento da DP (Venkateshappa et al., 2012).

Tendo em vista o envolvimento direto dos fatores neuroinflamatórios com a progressão da DP, as melhoras descritas acima nos marcadores de neuroinflamação nos animais treinados do nosso estudo podem participar das melhoras encontradas nos níveis de $\mathrm{TH}$ e no comportamento do grupo EX+DP. Parece haver uma diminuição da neurotoxicidade induzida pela 6-OHDA, e assim prevenção da morte de neurônios dopaminérgicos. Nossos dados corroboram estudos que demonstraram que a diminuição da expressão de fatores neuroinflamatórios mediado pelo exercício está diretamente relacionado com a melhora comportamental dos animais parkinsonianos (Dutra et al., 2012), dos níveis de TH (Sung et al., 2012), e assim, proteção do sistema dopaminérgico. 
No presente estudo, os níveis de TH nos animais exercitados parkinsonianos $(\mathrm{EX}+\mathrm{DP})$, tanto na SNc quanto no $\mathrm{CPu}$, apresentaram melhoras em relação ao grupo SED+DP no $7^{\circ}$ e $30^{\circ}$ dia pós-operatório. Por outro lado, o bloqueio do receptor de BDNF no momento da indução da DP bloqueou os efeitos preventivos promovidos pelo exercício. Logo, parece haver uma participação do mecanismo BDNF-TrkB na prevenção observada em nosso protocolo, assim como observamos em estudos anteriores de nosso grupo que avaliaram efeitos neuroprotetores em protocolos realizados após a indução do modelo da DP (Real et al., 2013). Juntamente com as melhoras neuroquímicas houve uma melhora comportamental onde animais com maiores níveis de $\mathrm{TH}$ apresentaram maior simetria no comportamento rotacional, ou seja, menor déficit motor como já foi descrito anteriormente (Henderson et al., 2003; Real et al., 2013; Yoon et al., 2007). Podemos sugerir que a piora no sistema dopaminérgico após o bloqueio do receptor de BDNF deve-se a perda dos efeitos promovidos por esta neurotrofina após a lesão. Estudos demonstraram que o BDNF é capaz de proteger e restaurar a função dos neurônios dopaminérgicos, além de melhorar os déficits nas funções motoras (Lindholm, Saarma, 2010). Além de participar de respostas compensatórias espontâneas quando há déficits dopaminérgicos, a deficiência ou ausência nos níveis neurotróficos por etiologia variada (tóxica, traumática, genética, metabólica e outros fatores) podem contribuir com a origem das doenças neurodegenerativas (Siegel, Chauhan, 2000).

Notamos que no $7^{0}$ dia de lesão houve uma queda na expressão de TH no $\mathrm{CPu}$ observado pela técnica de imuno-histoquímica no grupo EX+DP, com recuperação dos níveis de expressão após 30 dias. Este dado pode estar relacionado com respostas compensatórias do sistema dopaminérgico, já descritas por outros estudos. As respostas compensatórias podem ser divididas em dois grupos: um que está envolvido com a manutenção de uma concentração suficiente de DA no CPu (Zigmond et al., 1990), onde se incluem respostas como aumento da síntese, do metabolismo e da liberação DA pelos neurônios dopaminérgicos sobreviventes, além do prolongamento do tempo de depuração da DA extracelular (Deumens et al., 2002; Zigmond et al., 1990). O outro grupo está relacionado com o otimização da utilização de DA por neurônios sobreviventes (Zigmond et al., 1990). As respostas vistas neste segundo grupo incluem aumento de densidade e/ou 
sensibilidade dos receptores dopaminérgicos (Agid, 1991; Zigmond et al.,1990). Além dos mecanismos adaptativos metabólicos, a reorganização morfológica também pode contribuir nas respostas compensatórias da via nigroestriatal dopaminérgica (Blanchard et al., 1995; Finkelstein et al., 2000). Após 4 - 7 meses de lesão parcial na SNc ocorre hipertrofia e aumento no número de fibras TH-positivas. Esses resultados refletem uma recuperação axonal progressiva das fibras dopaminérgicas (Blanchard et al., 1995). Outros estudos mostram que, além dessa reorganização axonal, há um aumento da ramificação colateral dos terminais axônicos, sendo os terminais maiores e com mais vesículas se comparados aos animais sem lesão (Finkelstein et al., 2000). Assim, em nossos achados podemos sugerir que o exercício intermitente foi capaz de otimizar estes mecanismos compensatórios com recuperação mais precoce do sistema dopaminérgico no $\mathrm{CPu}$, revelando níveis de $\mathrm{TH}$ no $\mathrm{CPu}$ dos animais parkinsonianos treinados semelhante aos animais não parkinsonianos após um mês de lesão.

O aumento encontrado na expressão de BDNF na SNc do grupo SED+DP pode estar relacionado a um efeito endógeno protetor do sistema nervoso frente a uma lesão, pois mesmo com a diminuição de TH não houve diminuição de BDNF. Um estudo que analisou os níveis de BDNF e o modelo da DP demonstrou que após 7 dias da última injeção de MPTP (momento em que o protocolo do modelo da DP já foi concluído) há diminuição do número de células TH-positivas, porém não há alteração no número de células BDNF-positivas e nem na quantificação do BDNF por ELISA. Em modelos de lesão mecânica do CPu em ratos foi demonstrado que há um pico de expressão de BDNF na primeira semana pós lesão, caindo bruscamente após três semanas. Neste mesmo modelo pôde-se observar aumento do calibre e brotamento axonal em direção à lesão após 2 semanas da lesão. Isso sugere que o aumento de BDNF está envolvido com a plasticidade estrutural após lesão (Batchelor et al., 1999). Logo, podemos sugerir que há mecanismos compensatórios que são ativados com a diminuição de células dopaminérgicas, tais como a produção de citocinas e de fatores gliais, que podem mascarar os níveis de BDNF encontrados (Mocchetti et al., 2007). O aumento de BDNF pode não estar presente no grupo EX+DP devido aos menores déficits dopaminérgicos e menor ativação de fatores neuroinflamatórios em relação ao grupo SED+DP. 
Assim, nosso estudo pôde contribuir com o esclarecimento de alguns mecanismos envolvidos na prevenção da DP mediados pelo exercício físico intermitente em esteira; porém, mais estudos devem ser realizados para especificar as vias que participam da proteção do sistema dopaminérgico, e consequentemente do comportamento motor dos animais. Estes achados, por sua vez, podem ser muito úteis para o desenvolvimento de intervenções clínicas. 


\section{$\underline{5.4 \text { Conclusões }}$}

Os resultados descritos neste capítulo demonstram que 4 semanas de exercício intermitente em esteira antes da indução do modelo da DP foi capaz de prevenir alterações nos níveis de TH, BDNF, OX42, GFAP, iNOS e DHE, mecanismos que podem ter sido eficientes na prevenção da progressão da doença. Por outro lado, o bloqueio dos receptores TrkB em geral promoveu aumento nos déficits de $\mathrm{TH}$. Em adição, o dado comportamental corrobora os resultados neuroquímicos.

Em resumo, nossos dados revelaram que o exercício intermitente pôde proteger o sistema dopaminérgico dos efeitos promovidos pela injeção de 6-OHDA, capaz de manter os níveis de TH e o comportamento motor semelhante aos ratos não parkinsonianos. Demonstramos ainda, que a prevenção promovida pelo exercício intermitente parece ter o envolvimento de marcadores de neuroinflamação, tais como, ativação microglial, proliferação astrocitária, síntese de NO e estresse oxidativo; e do sistema BDNF-TrkB, sugerindo uma participação importante em mecanismos preventivos da DP. 


\section{CAPÍTULO 6- CONSIDERAÇÕES FINAIS}

Desta forma, nosso estudo, de modo geral, revelou que os 3 protocolos de exercício intermitente em esteira foram capazes de promover benefícios ao sistema dopaminérgico no modelo da DP. Além disso, o sistema BDNF-TrkB parece atuar em ambos os mecanismos investigados, ou seja, de neuroproteção e neuroprevenção, pois ao bloquearmos este mecanismo os déficits encontrados no modelo da DP, que são revertidos pelo exercício, estão presentes.

Assim, concluímos que independentemente de quando for iniciado, o exercício físico é benéfico ao sistema nervoso na DP, sendo capaz de promover melhoras neuroquímicas na DP, e consequentemente melhoras comportamentais. 


\section{REFERÊNCIAS ${ }^{4}$}

Aarsland D, Hutchinson M, Larsen JP. Cognitive, psychiatric and motor response to galantamine in Parkinson's disease with dementia. Int J Geriatr Psychiatry. 2003;18(10):93741.

Agid Y. Parkinson's disease: pathophysiology. Lancet. 1991;337(8753):1321-4. Review.

Ahlskog JE. Does vigorous exercise have a neuroprotective effect in Parkinson disease? Neurology. 2011;77(3):288-94. Review.

Alexander GE, Crutcher MD. Functional architecture of basal ganglia circuits: neural substrates of parallel processing. Trends Neurosci. 1990;13(7):266-71. Review.

Al-Jarrah M, Jamous M, Al Zailaey $\mathrm{K}$, Bweir SO. Endurance exercise training promotes angiogenesis in the brain of chronic/progressive mouse model of Parkinson's Disease. NeuroRehabilitation. 2010;26(4):369-73.

Alonso-Frech F, Sanahuja JJ, Rodriguez AM. Exercise and physical therapy in early management of Parkinson disease. Neurologist. 2011;(6 Suppl 1):S47-53.

Andringa G, van Oosten RV, Unger W, Hafmans TG, Veening J, Stoof JC, Cools AR. Systemic administration of the propargylamine CGP 3466B prevents behavioural and morphological deficits in rats with 6-hydroxydopamine-induced lesions in the substantia nigra. Eur J Neurosci. 2000;12(8):3033-43.

Arida RM, Scorza FA, Gomes da Silva S, Cysneiros RM, Cavalheiro EA. Exercise paradigms to study brain injury recovery in rodents. Am J Phys Med Rehabil. 2011;90(6):452-65.

Baptista PP, de Senna PN, Paim MF, Saur L, Blank M, do Nascimento P, Ilha J, Vianna MR, Mestriner RG, Achaval M, Xavier LL. Physical exercise down-regulated locomotor side effects induced by haloperidol treatment in Wistar rats. Pharmacol Biochem Behav. 2013;104:113-8.

Barbosa ER, Lefèvre BH, Comerlatti LR, Scaff M, Canelas HM. Neuropsychological dysfunctions in Parkinson's disease: a study of 64 cases. Arq Neuropsiquiatr. 1987;45(2):109-18.

Barthwal MK, Srivastava N, Dikshit M. Role of nitric oxide in a progressive neurodegeneration model of Parkinson's disease in the rat. Redox Rep. 2001;6(5):297-302.

Batchelor, PE, Liberatore, GT, Wong, JYF, Porritt, MJ, Frerichs, F, Donnan, GA, Howells, DW, Activated macrophages and microglia induce dopaminergic sprouting in the injured striatum and express brain-derived neurotrophic factor and glial cell line-derived neurotrophic factor. J Neuroscience. 1999;19(5):1708-16.

Baydyuk M, Nguyen MT, Xu B. Chronic Deprivation of TrkB Signaling Leads to Selective Lateonset Nigrostriatal Dopaminergic Degeneration. Exp Neurol. 2011;228(1):118-25.

\footnotetext{
${ }^{4}$ De acordo com:

International Committee of Medical Journal Editors. [Internet]. Uniform requirements for manuscripts submitted to Biomedical Journal: sample references. [updated 2011 Jul 15]. Available from: http://www.icmje.org
} 
Beal MF. Experimental models of Parkinson's disease. Nat Rev Neurosci. 2001;2:325-34.

Binder DK, Scharfman HE. Brain-derived neurotrophic factor. Growth Factors. 2004;22(3):123-31.

Blanchard V, Chritin M, Vyas S, Savasta M, Feuerstein C, Agid Y, Javoy-Agid F, RaismanVozari R. Long-term induction of tyrosine hydroxylase expression: compensatory response to partial degeneration of the dopaminergic nigrostriatal system in the rat brain. Journal of Neurochemistry. 1995;64:1669-79.

Blandini, F, Armentero, MT, Martignoni E. The 6-hydroxydopamine model: news from the past. Parkinsonism and Related Disorders. 2008;14:S124-S9. Review.

Blandini F, Levandis G, Bazzini E, Nappi G, Armentero MT. Time-course of nigrostriatal damage, basal ganglia metabolic changes and behavioural alterations following intrastriatal injection of 6-hydroxydopamine in the rat: new clues from an old model. Eur $\mathrm{J}$ Neurosci. 2007;25(2):397-405.

Blandini F, Nappi G, Tassorelli C, Martignoni E. Functional changes of the basal ganglia circuitry in Parkinson's disease. Prog Neurobiol. 2000;62(1):63-88. Review.

Blum D, Torch S, Lambeng N, Nissou M, Benabid AL, Sadoul R, Verna JM. Molecular pathways involved in the neurotoxicity of 6-OHDA, dopamine and MPTP: contribution to the apoptotic theory in Parkinson's disease. Prog Neurobiol. 200;65(2):135-72. Review.

Bové J, Prou D, Perier C, Przedborski S. Toxin-induced models of Parkinson's disease. NeuroRx. 2005;2(3):484-94.

Bowenkamp KE, Lapchak PA, Hoffer BJ, Miller PJ, Bickford PC. Intracerebroventricular glial cell line-derived neurotrophic factor improves motor function and supports nigrostriatal dopamine neurons in bilaterally 6-hydroxydopamine lesioned rats. Exp Neurol. 1997; 145(1):104-17.

Bradford MM. A rapid and sensitive method for the quantitation of microgram quantities of protein utilizing the principle of protein-dye binding, Anal Biochem. 1976;72:248.

Broadhurst PL. The place of animal psychology in the development of psychosomatic research. Fortschr Psychosom. 1960;1:63-9.

Broom L, Marinova-Mutafchieva L, Sadeghian M, Davis JB, Medhurst AD, Dexter DT. Neuroprotection by the selective iNOS inhibitor GW274150 in a model of Parkinson disease. Free Radic Biol Med. 2011;50(5):633-40.

Cadet P, Zhu W, Mantione K, Rymer M, Dardik I, Reisman S, Hagberg S, Stefano GB. Cyclic exercise induces anti-inflammatory signal molecule increases in the plasma of Parkinson's patients. Int J Mol Med. 2003;12(4):485-92.

Calabresi P, Centonze D, Pisani A, Sancesario G, Gubellini P, Marfia GA, Bernardi G. Striatal spiny neurons and cholinergic interneurons express differential ionotropic glutamatergic responses and vulnerability: implications for ischemia and Huntington's. Ann Neurol. 1998;43(5):586-97.

Calne DB. Neurodegenerative diseases. Philadelphia: WB Saunders, 1994. 
Calne DG. Is idiophatic parkinsonism the consequence of na event or a process? Neurology. 1994a;44:5-10.

Campos LA, Plehm R, Cipolla-Neto J, Bader M, Baltatu OC. Altered circadian rhythm reentrainment to light phase shifts in rats with low levels of brain angiotensinogen. Am J Physiol Regul Integr Comp Physiol. 2006;290(4):R1122-7.

Castano A, Herrera AJ, Cano J, Machado A. Lipopolysaccharide intranigral injection induces inflammatory reaction and damage in nigrostriatal dopaminergic system. J Neurochem. 1998;70:1584-92.

Cecanho, R. Anaya, M. Renzi, A. Menani, JV. De Luca, L. Sympathetic mediation of salivation induced by Intracerebroventricular pilocarpine in rats. J Autonomic Nervous System. 1999;76:9-14.

Chaudhuri KR, Healy DG, Schapira AH. Non-motor symptoms of Parkinson's disease: diagnosis and management. Lancet Neurol. 2006;5:235-45.

Chen H, Zhang SM, Schwarzschild MA, Herna' n MA, Ascherio A. Physical activity and the risk of Parkinson disease. Neurology. 2005;64:664-9.

Chen XY, Li J, Qi WQ, Shen SH. Experimental change on dopaminergic neurons in striatum of Parkinson disease rats. Histol Histopathol. 2007;22(10):1085-90.

Cicchetti F, Brownell AL, Williams K, Chen YI, Livni E, Isacson O. Neuroinflammation of the nigrostriatal pathway during progressive 6-OHDA dopamine degeneration in rats monitored by immunohistochemistry and PET imaging. Eur J Neurosci. 2002;15(6):991-8.

Cohen AD, Tillerson JL, Smith AD, Schallert T, Zigmond MJ. Neuroprotective effects of prior limb use in 6-hydroxydopamine-treated rats: possible role of GDNF. J Neurochem. 2003;85(2):299-305.

Conti A, Miscusi M, Cardali S, Germanò A, Suzuki H, Cuzzocrea S, Tomasello F. Nitric oxide in the injured spinal cord: synthases cross-talk, oxidative stress and inflammation. Brain Res Rev. 2007;54(1):205-18. Review.

Cotman CW, Berchtold NC. Exercise: a behavioral intervention to enhance brain health and plasticity. Trends Neurosci. 2002;25(6):295-301.

Cummings JL. Depression and Parkinson's disease: a review. Am J Psychiatry. 1992;149(4):443-54. Review.

Cummings JL. The dementias of Parkinson's disease: prevalence, characteristics, neurobiology, and comparison with dementia of the Alzheimer type. Eur Neurol. 1988;28 Suppl1:15-23. Review.

Dahlstrom A, Fuxe K. Localization of monoamines in the lower brain stem. Experientia. 1964; 20,398-9.

Dauer W, Przedborski S. Parkinson's disease: mechanisms and models. Neuron. 2003; 39:889-909. 
Dehmer T, Lindenau J, Haid S, Dichgans J, Schulz JB. Deficiency of inducible nitric oxide synthase protects against MPTP toxicity in vivo. J Neurochem. 2000;74(5):2213-6.

Deumens R, Blokland A, Prickaerts J. Modeling Parkinson's disease in rats: an evaluation of 6-OHDA lesions of the nigrostriatal pathway. Exp Neurol. 2002;175(2):303-17. Review.

Devi SA, Kiran TR. Regional responses in antioxidant system to exercise training and dietary vitamin E in aging rat brain. Neurobiol Aging. 2004;25(4):501-8.

Dexter DT, CJ Carter, FR Wells, F Javoy-Agid, Y Agid, A Lees, P Jenner and CD Marsden. Basal lipid peroxidation in substantia nigra is increased in Parkinson's disease. J Neurochem. 1989;52:381-9.

Doyon J, Bellec P, Amsel R, Penhune V, Monchi O, Carrier J, Lehéricy S, Benali H. Contributions of the basal ganglia and functionally related brain structures to motor learning. Behav Brain Res. 2009;199(1):61-75. Review.

Dutra MF, Jaeger M, Ilha J, Kalil-Gaspar PI, Marcuzzo S, Achaval M. Exercise improves motor deficits and alters striatal GFAP expression in a 6-OHDA-induced rat model of Parkinson's disease. Neurol Sci. 2012 Oct;33(5):1137-44.

Dutta G, Zhang P, Liu B. The lipopolysaccharide Parkinson's disease animal model: mechanistic studies and drug discovery. Fundam Clin Pharmacol. 2008;22:453-64.

Elbaz A. and Moisan F. Update in the epidemiology of Parkinson's disease. Curr Opin Neurol. 2008;21:454-60.

Eng LF, Ghirnikar RS, Lee YL. Glial fibrillary acidic protein: GFAP-thirty-one years (19692000). Neurochem Res. 2000;25(9-10):1439-51. Review.

Fearnley JM, Lees AJ. Ageing and Parkinson's disease: substantia nigra regional selectivity. Brain. 1991;114(Pt 5):2283-301.

Felix JV, Michelini LC. Training-induced pressure fall in spontaneously hypertensive rats is associated with reduced angiotensinogen mRNA expression within the nucleus tractus solitarii. Hypertension. 2007;50(4):780-5.

Ferreira, Ana Francisca Barros. Neuroplasticidade induzida pelo exercício: efeitos sobre o hipocampo e regiões motoras do encéfalo de ratos. [tese (Doutorado em Fisiologia Humana]. São Paulo: Instituto de Ciências Biomédicas, Universidade de São Paulo; 2011.

Ferrer I, López-Gonzalez I, Carmona M, Dalfó E, Pujol A, Martínez A. Neurochemistry and the non-motor aspects of PD. Neurobiol Dis. 2012;46(3):508-26. Review.

Finkelstein DI, Stanic D, Parish CL, Tomas D, Dickson K, Horne MK. Axonal sprouting following lesions of the rat substantia nigra. Neuroscience. 2000;97:99-112.

Fisher BE , Wu AD , Salem GJ , Canção J , Lin CH , J Yip , Cen S , Gordon J , Jakowec M , G Petzinger The effect of exercise training in improving motor performance and corticomotor excitability in people with earlyParkinson's disease. Arch Phys Med Rehabil. 2008;89 (7):1221-9.

Floyd RA. Antioxidants, oxidative stress, and degenerative neurological disorders. Proc Soc Exp Biol Med. 1999;222:236-45 
Fornaguera J, Schwarting RK. Early behavioral changes after nigro-striatal system damage can serve as predictors of striatal dopamine depletion. Prog Neuropsychopharmacol Biol Psychiatry. 1999; 23(8):1353-68.

Fujita K, Seike T, Yutsudo N, Ohno M, Yamada H, Yamaguchi H, Sakumi K, Yamakawa Y, Kido MA, Takaki A, Katafuchi T, Tanaka Y, Nakabeppu Y, Noda M. Hydrogen in drinking water reduces dopaminergic neuronal loss in the 1-methyl-4-phenyl-1,2,3,6tetrahydropyridine mouse model of Parkinson's disease. PLoS One. 2009;4(9):e7247.

Garcia PC, Real CC, Ferreira AF, Alouche SR, Britto LR, Pires RS. Different protocols of physical exercise produce different effects on synaptic and structural proteins in motor areas of the rat brain. Brain Res. 2012;1456:36-48.

Glezer I, Lapointe A, Rivest S. Innate immunity triggers oligodendrocyte progenitor reactivity and confines damages to brain injuries. FASEB J. 2006;20(6):750-2.

Golbe LI. Young-onset Parkinson's disease: a clinical review. Neurology. 1991;41(2)168-73. Review.

Goldman PS, Nauta WJ. An intricately patterned prefronto-caudate projection in the rhesus monkey. J Comp Neurol. 1977;72(3):369-86.

Goodwin VA, Richards SH, Taylor RS, Taylor AH, Campbell JL. The effectiveness of exercise interventions for people with Parkinson's disease: a systematic review and metaanalysis. Mov Disord. 2008;23(5):631-40. Review.

Goodwin VA, Richards SH, Henley W, Ewings P, Taylor AH, Campbell JL. An exercise intervention to prevent falls in people with Parkinson's disease: a pragmatic randomised controlled trial. J Neurol Neurosurg Psychiatry. 2011;82(11):1232-8.

Gordon MN, Schreier WA, Ou X, Holcomb LA, Morgan DG. Exaggerated astrocyte reactivity after nigrostriatal deafferentation in the aged rat. J Comp Neurol. 1997;388:106-19

Graybiel AM, Ragsdale CW. Biochemical anatomy of the striatum. In: Emson PC, editor. Chemical neuroanatomy. New York: Raven Press; 1983. p. 427-504.

Greenamyre JT, Hastings TG. Biomedicine. Parkinson's - divergent causes, convergent mechanisms. Science. 2004;304:1120-22.

Grigor'ian GA, Bazian AS. The experimental models of Parkinson's disease in animals Usp Fiziol Nauk. 2007;38(4):80-8.

Henderson JM, Watson S, Halliday GM, Heinemann T, Gerlach M. Relationships between various behavioural abnormalities and nigrostriatal dopamine depletion in the unilateral 6OHDA-lesioned rat. Behav Brain Res. 2003;139(1-2):105-13.

Henning J, Strauss U, Wree A, Gimsa J, Rolfs A, Benecke R, Gimsa U. Differential astroglial activation in 6-hydroxydopamine models of Parkinson's disease. Neurosci Res. 2008 Dec;62(4):246-53.

Hensley K, ML Maidt, Z Yu, H Sang, WR Markesbery and RA Floyd. Electrochemical analysis of protein nitrotyrosine and dityrosine in the Alzheimer brain indicates region-specific accumulation. J Neurosci. 1998;18:8126-32. 
Herman T, Giladi N, Gruendlinger L, Hausdorff JM. Six weeks of intensive treadmill training improves gait and quality of life in patients with Parkinson's disease: a pilot study. Arch Phys Med Rehabil. 2007;88(9):1154-8.

Hernandes, MS, Britto LR, Real CC, Martins DO, Lopes LR. Reactive oxygen species and the structural remodeling of the visual system after ocular enucleation. Neuroscience. 2010;170(4):1249-60.

Hirsch MA, Farley BG. Exercise and neuroplasticity in persons living with Parkinson's disease. Eur J Phys Rehabil Med. 2009;45(2):215-29.

Holloszy JO, Kohrt WM. Exercise. In: Masoro EJ, editor. Handbook of physiology. Aging. New York: Oxford Press; 1995. p. 633-66.

Holmes MM, Galea LA, Mistlberger RE, Kempermann G. Adult hippocampal neurogenesis and voluntary running activity: circadian and dose dependent effects. J Neurosci Res. 2004;76(2):216-22.

Howells DW, Porritt MJ, Wong JY, Batchelor PE, Kalnins R, Hughes AJ, Donnan GA. Reduced BDNF mRNA expression in the Parkinson's disease substantia nigra. Exp Neurol. 2000;166(1):127-35.

Hughes AJ, Daniel SE, Blankson S, Lees AJ. A clinicopathologic study of 100 cases of Parkinson's disease. Arch Neurol. 1993;50(2):140-8.

Hunot S, Boissière F, Faucheux B, Brugg B, Mouatt-Prigent A, Agid Y, Hirsch EC. Nitric oxide synthase and neuronal vulnerability in Parkinson's disease. Neuroscience. 1996;72(2):355-63.

Iravani MM, Kashefi K, Mander P, Rose S, Jenner P. Involment of inducible nitric oxide synthase in inflammation-induced dopaminergic neurodegeneration. Neuroscience. 2002; 110(1):49-58.

Jellinger K, Linert L, Kienzl E, Herlinger E, Youdim MB. Chemical evidence for 6hydroxydopamine to be an endogenous toxic factor in the pathogenesis of Parkinson's disease. J Neural Transm Suppl. 1995;46:297-314.

Jin F, Wu Q, Lu YF, Gong QH, Shi JS. Neuroprotective effect of resveratrol on 6-OHDAinduced Parkinson's disease in rats. Eur J Pharmacol. 2008;600(1-3):78-82.

Kafitz KW, Rose CR, Thoenen H, Konnerth A. Neurotrophin-evoked rapid excitation through TrkB receptors. Nature. 1999;401(6756):918-21.

Kamata H, Hirata H. Redox regulation of cellular signalling. Cell Signal. 1999;11(1):1-14.

Kandel ER, Schwartz JH, Jessell TM, Siegelbaum SA, Hudspeth AJ. Principles of neural science. 5th ed. New York: McGraw-Hill; 2012.

Kavya R, Saluja $R$, Singh S, Dikshit M. Nitric oxide synthase regulation and diversity: implications in Parkinson's disease. Nitric Oxide. 2006;15(4):280-94. Review.

Kempermann G, Kuhn HG, Gage FH. Experience-induced neurogenesis in the senescent dentate gyrus. J Neurosci. 1998;18(9):3206-12. 
Kempermann G, Kuhn HG, Gage FH. More hippocampal neurons in adult mice living in an enriched environment. Nature. 1997;386(6624):493-5.

Kim WG, Mohney RP, Wilson B, Jeohn GH, Liu B, Hong JS. Regional difference in susceptibility to lipopolysaccharide-induced neurotoxicity in the rat brain: role of microglia. $J$ Neurosci. 2000;20(16):6309-16.

Kim BS, Kim MEU, Leem YH. Hippocampal neuronal death induced by kainic acid and restraint stress is suppressed by exercise. Neuroscience. 2011;194:291-301.

Kirik D, Rosenblad C, Björklund A. Characterization of behavioral and neurodegenerative changes following partial lesions of the nigrostriatal dopamine system induced by intrastriatal 6-hydroxydopamine in the rat. Exp Neurol. 1998;152(2):259-77.

Kita H. Glutamatergic and GABAergic postsynaptic responses of striatal spiny neurons to intrastriatal and cortical stimulation recorded in slice preparations. Neuroscience. 1996; 70(4):925-40.

Knott $A B$, Bossy-Wetzel E. Nitric oxide in health and disease of the nervous system. Antioxid Redox Signal. 2009;11(3):541-54.

Knüsel B, Hefti F. K-252 compounds: modulators of neurotrophin signal transduction. J Neurochem. 1992;59(6):1987-96. Review.

Kondo J, Kitanura Y, Inden M, Taniguchi T. Hemiparkinsonian rat models: different sensitivity of dopaminergic neurotoxins. Int Congr Ser. 2004;1260:281-5.

Koppula S, Kumar H, Kim IS, Choi DK. Reactive oxygen species and inhibitors of inflammatory enzymes, NADPH oxidade, and iNOS in experimental models of Parkinson's disease. Mediators Inflamm. 2012;2012:823902.

Kronengerg G, Bick-Sander A, Bunk E, Wolf C, Ehninger D, Kempermann G. Physical exercise prevents age-related decline in precursor cell activity in the mouse dentate gyrus. Neurobiol Aging. 2006;27(10):1505-1513.

Kurkowska-Jastrzebska I, Wrońska A, Kohutnicka M, Członkowski A, Członkowska A. MHC class II positive microglia and lymphocytic infiltration are present in the substantia nigra and striatum in mouse model of Parkinson's disease. Acta Neurobiol Exp(Wars). 1999b;59(1):1-8.

Kurkowska-Jastrzebska I, Wrońska A, Kohutnicka M, Członkowski A, Członkowska A. he inflammatory reaction following 1-methyl-4-phenyl-1,2,3, 6-tetrahydropyridine intoxication in mouse. Exp Neurol. 1999a Mar;156(1):50-61.

Kuroda K, Tatara K, Takatorige T, Shinsho F. Effect of physical exercise on mortality in patients with Parkinson's disease. Acta Neurol Scand. 1992;86(1):55-9.

Kuroda K, Tatara K, Shinsho H, Okamoto E, Cho R, Nishigaki C, Takatorige T, Nakanishi N, Aoki T. A study of attitudes toward illness and its effect on mortality in patients with Parkinson's disease. Nippon Koshu Eisei Zasshi. 1990;37(5):333-9.

Labandeira-Garcia JL, Rozas G, Lopez-Martin E, Liste I, Guerra MJ. Time course of striatal changes induced by 6-hydroxydopamine lesion of the nigrostriatal pathway, as studied by combined evaluation of rotational behaviour and striatal Fos expression. Exp Brain Res. 1996;108(1):69-84. 
Lacerda AC, Gripp F, Rodrigues LO, Silami-Garcia E, Coimbra CC, Prado LS. Acute heat exposure increases high-intensity performance during sprint cycle exercise. Eur J Appl Physiol. 2007;99(1):87-93.

Laemmli UK. Cleavage of structural proteins during the assembly of the head of bacteriophage T4. Nature. 1970;227(5259):680-5.

Lambert TJ, Fernandez SM, Frick KM. Different types of environmental enrichment have discrepant effects on spatial memory and synaptophysin levels in female mice. Neurobiol Learn Mem. 2005;83(3):206-16.

Langston JW, Forno LS, Tetrud J, Reeves AG, Kaplan JA, Karluk D. Evidence of active nerve cell degeneration in the substantia nigra of humans years after 1-methyl-4-phenyl1,2,3,6-tetrahydropyridine exposure. Ann Neurol. 1999;46:598-605.

Lau YS, Patki G, Das-Panja K, Le WD, Ahmad SO. Neuroprotective effects and mechanisms of exercise in a chronic mouse model of Parkinson's disease with moderate neurodegeneration. Eur J Neurosci. 2011;33(7):1264-74

Lee CS, Sauer H, Björklund A. Dopaminergic neuronal degeneration and motor impairments following axon terminal lesion by intrastriatal 6-Hydroxydopamine in the rat. Neuroscience. 1996;72(3):641-53.

Lee JK, Tran T, Tansey MG. Neuroinflammation in Parkinson's disease. J Neuroimmune Pharmacol. 2009;4:419-29

Liang Y, Li S, Wen C, Zhang Y, Guo Q, Wang H, Su B. Intrastriatal injection of colchicine induces striatonigral degeneration in mice. J Neurochem. 2008;106(4):1815-27.

Liedtke W, Edelmann W, Chiu FC, Kucherlapati R, Raine CS. Experimental autoimmune encephalomyelitis in mice lacking glial fibrillary acidic protein is characterized by a more severe clinical course and an infiltrative central nervous system lesion. Am J Pathol. 1998;152(1):251-9.

Lima, Leandro Bueno. Organização das projeções da área tegmental ventral para o estriado. Um estudo no rato com a técnica de rastreamento anterógrado da leucoaglutina do Phaseolus vulgaris. [dissertação (Mestrado em Fisiologia Humana)]. São Paulo: Instituto de Ciências Biomédicas, Universidade de São Paulo; 2010.

Lindholm P, Saarma M. Novel CDNF/MANF family of neurotrophic factors. Developmental neurobiology. 2010;70(5):360-71.

Logroscino G, Sesso HD, Paffenbarger RS Jr, Lee IM. Physical activity and risk of Parkinson's disease: a prospective cohort study. J Neurol Neurosurg Psychiatry. 2006; 77(12):1318-22.

Lom B, Cohen-Cory S. Brain-derived neurotrophic factor differentially regulates retinal ganglion cell dendritic and axonal arborization in vivo. J Neurosci. 1999;19(22):9928-38.

Maragakis NJ, Rothstein JD. Mechanisms of disease: astrocytes in neurodegenerative disease. Nat Clin Pract Neurol. 2006;2(12):679-89. Review. 
Marinova-Mutafchieva L, Sadeghian M, Broom L, Davis JB, Medhurst AD, Dexter DT. Relationship between microglial activation and dopaminergic neuronal loss in the substantia nigra: a time course study in a 6-hydroxydopamine model of Parkinson's disease. J Neurochem. 2009;110(3):966-75.

Marosi K, Bori Z, Hart N, Sárga L, Koltai E, Radák Z, Nyakas C. Long-term exercise treatment reduces oxidative stress in the hippocampus of aging rats. Neuroscience. 2012;226:21-8.

Mattson MP. Gleichmann M, Cheng A. Mitochondria in neuroplasticity and neurological disorders. Neuron. 2008;60(5):748-66. Review.

Mattson MP. Calcium and neurodegeneration. Aging Cell. 2007;6(3):337-50. Review.

Mattson MP. Neuroprotective signaling and the aging brain: take away my food and let me run. Brain Res. 2000;886:47-53.

McGeer PL, McGeer EG. Inflammation and neurodegeneration in Parkinson's disease. Parkinsonism Relat Disord. 2004;10 Suppl 1:S3-7. Review.

McKeith IG, Dickson DW, Lowe J, Emre M, O'Brien JT, Feldman H, Cummings J, Duda JE, Lippa C, Perry EK, Aarsland D. Diagnosis and management of dementia with Lewy bodies: third report of the DLB Consortium. Neurology. 2005;65:1863-72.

Michailowsky C, Niura FK, do Valle AC, Sonohara S, Meneguin TD, Tsanaclis AM. Experimental tumors of the central nervous system: standardisation of a model in rats using the 9L glioma cells. Arq Neuropsiquiatr. 2003;61(2A):234-40.

Melo LM, Barbosa ER, Caramelli P. Declínio cognitivo e demência associados à doença de Parkinson: características clínicas e tratamento. Rev Psiq Clín. 2007;34(4);176-83. Revisão.

Mello, PB; Bentti, F; Martín C; Izquierdo I. Effects of acute and chronic physical exercise and stress on different types of memory in rats. Annals of the Brazilian Academy of Sciences. 2008;80(2):301-9.

Mink JW. Basal Ganglia. In: Zigmund MJ, Bloon FE, Lands SC, Roberts JL, Squire LR. Fundamental neuroscience. San Diego: Academic Press; 1999.

Mocchetti I, Bachis A, Nosheny RL, Tanda G. Brain-derived neurotrophic factor expression in the substantia nigra does not change after lesions of dopaminergic neurons. Neurotox Res. 2007;12(2):135-43.

Molteni R, Zheng JQ, Ying Z, Gómez-Pinilla F, Twiss JL. Voluntary exercise increases axonal regeneration from sensory neurons. Proc Natl Acad Sci U S A. 2004a;101(22):84738.

Molteni R, Wu A, Vaynman S, Ying Z, Barnard RJ, Gomez-Pinilla F. Exercise reverses the harmful effects of consumption of a high-fat diet on synaptic and behavioral plasticity associated to the action of brain-derived neurotrophic factor. Neuroscience. 2004b;123(2):429-40.

Neumann J, Gunzer M, Gutzeit HO, Ullrich O, Reymann KG, Dinkel K. Microglia provide neuroprotection after ischemia. FASEB J. 2006;20(6):714-6. 
Nguyen N, Lee SB, Lee YS, Lee KH, Ahn JY. Neuroprotection by NGF and BDNF Against Neurotoxin-Exerted Apoptotic Death in Neural Stem Cells Are Mediated Through Trk Receptors, Activating PI3-Kinase and MAPK Pathways. Neurochem Res. 2009;34(5):942-51.

Noback CR, Strominger NL, Demarest RJ. Neuroanatomia: estrutura e função do sistema nervoso humano. 5. ed. São Paulo: Premier; 1999.

O'Dell SJ, Gross NB, Fricks AN, Casiano BD, Nguyen TB, Marshall JF. Running wheel exercise enhances recovery from nigrostriatal dopamine injury without inducing neuroprotection. Neuroscience. 2007;144(3):1141-51.

Obeso JA, Rodríguez-Oroz MC, Benitez-Temino B, Blesa FJ, Guridi J, Marin C, Rodriguez M. Functional organization of the basal ganglia: therapeutic implications for Parkinson's disease. Mov Disord. 2008;23 Suppl 3:S548-59. Review.

Obeso JA, Rodríguez-Oroz MC, Rodríguez M, Lanciego JL, Artieda J, Gonzalo N, Olanow CW. Pathophysiology of the basal ganglia in Parkinson's disease. Trends Neurosci. 2000;23(10 Suppl):S8-19. Review.

Olanow C, Tatton W. Etiology and pathogenesis of Parkinson's disease. Annu Rev Neurosci. 1999;22:123-44.

Ouchi Y, Yoshikawa E, Sekine Y, Futatsubashi M, Kanno T, Ogusu T, Torizuka T. Microglial activation and dopamine terminal loss in early Parkinson's disease. Ann Neurol. 2005;57(2):168-75.

Palmer SS, Mortimer JA, Webster DD, Bistevins R, Dickinson GL. Exercise therapy for Parkinson's disease. Arch Phys Med Rehabil. 1986;67(10):741-5.

Parkinson J. An essay on the shaking palsy. 1817. J Neuropsychiatry Clin Neurosci. 2002; Spring;14(2):223-36; discussion 222.

Paxinos G, Watson C. The rat brain in stereotaxic coordinates. 3. ed. San Diego: Academic Press; 2005.

Pérez V, Sosti V, Rubio A, Barbanoj M, Rodríguez-Alvarez J, Kulisevsky J. Modulation of the motor response to dopaminergic drugs in a parkinsonian model of combined dopaminergic and noradrenergic degeneration. Eur J Pharmacol. 2007;576(1-3):83-90.

Pestana RRF. Geração de espécies reativas de oxigênio e morte neuronal no modelo de epilepsia do lobo temporal induzido por pilocarpina em ratos [dissertação]. São Paulo: Universidade de São Paulo, Instituto de Psicologia; 2010.

Petzinger GM, Walsh JP, Akopian G, Hogg E, Abernathy A, Arevalo P, Turnquist P, Vucković M, Fisher BE, Togasaki DM, Jakowec MW. Effects of treadmill exercise on dopaminergic transmission in the 1-methyl-4-phenyl-1,2,3,6-tetrahydropyridine-lesioned mouse model of basal ganglia injury. J Neurosci. 2007;27(20):5291-300.

Phani S, Loike JD, Przedborski S. Neurodegeneration and inflammation in Parkinson's disease. Parkinsonism Relat Disord. 2012;18 Suppl 1:S207-9.

Poon HF, V Calabrese, G Scapagnini and DA Butterfield. Free radicals: key to brain aging and heme oxygenase as a cellular response to oxidative stress. J Gerontol A Biol Sci Med Sci 2004;59:478-93. 
Porter CC, Totaro JA, Burcin A. The relationship between radioactivity and norepinephrine concentrations in the brains and hearts of mice following administration of labeled methyldopa or 6-hydroxydopamine. J Pharmacol Exp Ther. 1965;150:17-22.

Porter CC, Totaro JA, Stone CA. Effect of 6-hydroxydopamine and some other compounds on the concentration of norepinephrine in the hearts of mice. $J$ Pharmacol Exp Ther. 1963;140:308-16.

Purisai MG, McCormack AL, Cumine S, Li J, Isla MZ, Di Monte DA. Microglial activation as a priming event leading to paraquat-induced dopaminergic cell degeneration. Neurobiol Dis. 2007;25:392-400.

Phani S, Loike JD, Przedborski S. Neuroinflammation is a key player in Parkinson's disease and a prime target for therapy. J Neural Transm. 2010;117(8):971-9.

Radák Z, Silye G, Bartha C, Jakus J, Stefanovits-Bányai E, Atalay M, Marton O, Koltai E. The effects of cocoa supplementation, caloric restriction, and regular exercise, on oxidative stress markers ofbrain and memory in the rat model. Food Chem Toxicol. 2013;S02786915(13)00095-1.

Radák Z, Chung HY, Goto S. Systemic adaptation to oxidative challenge induced by regular exercise. Free Radic Biol Med. 2008;44(2):153-9. Review.

Radák Z, Naito H, Kaneko T, Tahara S, Nakamoto H, Takahashi R, Cardozo-Pelaez F, Goto $\mathrm{S}$, Exercise training decreases DNA damage and increases DNA repair and resistance against oxidative stress of proteins in aged rat skeletal muscle. Pflug Arch. 2002;445:273-8.

Radák Z, Kaneko T, Tahara S, Nakamoto H, Pucsok J, Sasvári M, Nyakas C, Goto S. Regular exercise improves cognitive function and decreases oxidative damage in rat brain. Neurochem Int. 2001;38(1):17-23.

Radák Z, Taylor AW, Ohno H, Goto S. Adaptation to exercise-induced oxidative stress: from muscle to brain. Exerc Immunol Rev. 2001;7:90-107.

Real CC, Ferreira AF, Chaves-Kirsten GP, Torrão AS, Pires RS, Britto LR. BDNF receptor blockade hinders the beneficial effects of exercise in a rat model of Parkinson's disease. Neuroscience. 2013;237C:118-29.

Riddle DR, Katz LC, Lo DC. Focal delivery of neurotrophins into the central nervous system using fluorescent latex microspheres. Biotechniques. 1997;23(5):928-34, 936-7.

Rio-Hortega P del. El tercer elemento de los centros nerviosos. Poder fagocitario y movilidad de la microglia. Bol Soc Esp Biol. 1920;9:154.

Rizelio V, Szawka RE, Xavier LL, Achaval M, Rigon P, Saur L, Matheussi F, Delattre AM, Anselmo-Franci JA, Meneses M, Ferraz AC. Lesion of the subthalamic nucleus reverses motor deficts but not death of nigrostriatal dopaminergic neurons in a 6-hydroxydopaminelesion model of Parkinson's disease. Braz J Med Biol Res. 2010;43(1):85-95. 
Rodriguez-Pallares J, Parga JA, Muñoz A, Rey P, Guerra MJ, Labandeira-Garcia JL. Mechanism of 6-hydroxydopamine neurotoxicity: the role of NADPH oxidase and microglial activation in 6-hydroxydopamine-induced degeneration of dopaminergic neurons. J Neurochem. 2007;103(1):145-56.

Rueda, André Veloso Lima. O enriquecimento ambiental inibe a sensibilização comportamental ao etanol em camundongos: efeitos sobre o Egr-1 e a sinalização do BDNF. [dissertação (Mestrado em Farmacologia)]. São Paulo: Instituto de Ciências Biomédicas, Universidade de São Paulo; 2011.

Salgado-Delgado R, Angeles-Castellanos M, Buijs MR, Escobar C. Internal desynchronization in a model of night-work by forced activity in rats. Neuroscience. 2008; 154(3):922-31.

Sasco AJ, Paffenbarger Jr RS, Gendre I, Wing AL. The role of physical exercise in the occurrence of Parkinson's disease. Arch Neurol. 1992;49(4):360-5.

Scandalios JG. Oxidative stress responses-what have genome-scale studies taught us?. Genoma Biol. 2002;3(7):REVIEWS1019.

Schmued LC, Hopkins KJ. Fluoro-Jade B: a high affinity fluorescent marker for the localization of neuronal degeneration. Brain Res. 2000;874:123-30.

Schober A. Classic toxin-induced animal models of Parkinson's disease: 6-OHDA and MPTP. Cell Tissue Res. 2004;318:215-4.

Schwarting RK, Huston JP. The unilateral 6-hydroxydopamine lesion model in behavioral brain research. Analysis of functional deficits, recovery and treatments. Prog Neurobiol. 1996;50(2-3):275-331. Review.

Senoh S, Witkop B Non-enzymatic conversions of dopamine to norepinephrine and rihydroxyphenetylamines. J Am Chem Soc. 1959a;81:6222-31.

Senoh S, Creveling CR, Udenfriend S, Witkop B Chemical, enzymatic, and metabolic studies on the mechanism of oxidation of dopamine. J Am Chem Soc. 1959b;6236-40.

Siegel GJ, Chauhan NB. Neurotrophic factors in Alzheimer's and Parkinson's disease brain. Brain Res Brain Res Rev. 2000 Sep;33(2-3):199-227. Review.

Sies H, Cadenas E. Oxidative stress: damage to intact cells and organs. Philos Trans R Soc Lond B Biol Sci 1985;311:617-31.

Singh S, Ahmad R, Mathur D, Sagar RK, Krishana B. Neuroprotective effect of BDNF in young and aged 6-OHDA treated rat model of Parkinson disease. Indian $J$ Exp Biol. 2006;44(9):699-704.

Smeyne M, Jiao Y, Shepherd KR, Smeyne RJ. Glia cell number modulates sensitivity to MPTP in mice. Glia. 2005;52:144-52.

Smith AD, Zigmond MJ. Can the brain be protected through exercise? Lessons from an animal model of parkinsonism. Exp Neurol. 2003;184(1):31-9. Review. 
Somani SM, Husain K, Diaz-Phillips L, Lanzotti DJ, Kareti KR, Trammell GL. Interaction of exercise and ethanol on antioxidant enzymes in brain regions of the rat. Alcohol 1996;13:603-10.

Somani SM, Ravi R, Rybak LP. Effect of exercise training on antioxidant system in brain regions of rat. Pharmacol Biochem Behav. 1995;50(4):635-9.

Srinivasan J, Schmidt WJ. Behavioral and neurochemical effects of noradrenergic depletions with $\mathrm{N}$-(2-chloroethyl)-N-ethyl-2-bromobenzylamine in 6-hydroxydopamine-induced rat model of Parkinson's disease. Behav Brain Res. 2004;151(1-2):191-9.

Sriram K, Miller DB, O'Callaghan JP. Minocycline attenuates microglial activation but fails to mitigate striatal dopaminergic neurotoxicity: role of tumor necrosis factor-alpha. J Neurochem. 2006;96(3):706-18.

Steiner B, Winter C, Hosman K, Siebert E, Kempermann G, Petrus DS, Kupsch A. Enriched environment induces cellular plasticity in the adult substantia nigra and improves motor behavior function in the 6-OHDA rat model of Parkinson's disease. Exp Neurol. 2006;199(2):291-300.

Su W, Chen HB, Li SH, Wu DY. Correlational study of the serum levels of the glial fibrillary acidic protein and neurofilament proteins in Parkinson's disease patients. Clin Neurol Neurosurg. 2012;114(4):372-5.

Sugama S, Yang L, Cho BP, DeGiorgio LA, Lorenzl S, Albers DS, Beal MF, Volpe BT, Joh TH. Age-related microglial activation in 1-methyl-4-phenyl-1,2,3,6-tetrahydropyridine (MPTP)induced dopaminergic neurodegeneration in C57BL/6 mice. Brain Res. 2003;964(2):288-94.

Sumic A, Michael YL, Carlson NE, Howieson DB, Kaye JA. Physical Activity and the Risk of Dementia in Oldest Old. Journal of Aging \& Health. 2007;19(2):242-59.

Sung YH, Kim SC, Hong HP, Park CY, Shin MS, Kim CJ, Seo JH, Kim DY, Kim DJ, Cho HJ. Treadmill exercise ameliorates dopaminergic neuronal loss through suppressing microglial activation in Parkinson's disease mice. Life Sci. 2012;17;91(25-26):1309-16.

Sutoo D, Akiyama K. Regulation of brain function by exercise. Neurobiol Dis. 2003;13(1):114. Review.

Tajiri N, Yasuhara T, Shingo T, et al. Exercise exerts neuroprotective effects on Parkinson's disease model of rats. Brain Research. 2010;200-207.

Tanaka K, Ogawa N, Asanuma M. Molecular basis of 6-hydroxydopamine-induced caspase activations due to increases in oxidative stress in the mouse striatum. Neurosci Lett. 2006;410(2):85-9.

Thornton E, Vink $R$. Treatment with a substance $P$ receptor antagonist is neuroprotective in the 6-hydroxydopamine model of early Parkinson's disease. PLoS One. 2012;7(4):e34138.

Tillerson JL, Caudle WM, Reverón ME, Miller GW. Exercise induces behavioral recovery and attenuates neurochemical deficits in rodent models of Parkinson's disease. Neuroscience. 2003;119(3):899-911. 
Tillerson JL, Cohen AD, Caudle WM, Zigmond MJ, Schallert T, Miller GW. Forced nonuse in unilateral parkinsonian rats exacerbates injury. J Neurosci. 2002;22(15):6790-9.

Toole T, Hirsch MA, Forkink A, Lehman DA, Maitland CG. The effects of a balance and strength training program on equilibrium in Parkinsonism: a preliminary study. NeuroRehabilitation. 2000;14(3):165-74.

Towbin H, StaehelinT, GordonJ. Electrophoretic transfer of proteins from polyacrylamide gels to nitrocellulose sheets: procedure and some applications. 1979. York: Raven Press, 1983:427-504.

Tretiakoff C. Contribution à l'étude de l'anatomie pathologique du locus niger de Soemmering avec quelques déductions realtives à la pathogénie de troubles du tônus musculaire et la maladie de Parkinson. Thése de Médecine, Paris (1919).

Turgeon JL, Waring DW. Differential expression and regulation of progesterone receptor isoforms in rat and mouse pituitary cells and LbT2 gonadotropes. J Endocr. 2006;190:83746.

Ungerstedt U. 6-hydroxydopamine induced degeneration of central monoamine neurons. Eur J Pharmacol. 1968;5:107-10.

Valko MD, Leibfritz D, Moncol J, Cronin MT, Mazur M, Telser J .Free radicals and antioxidants in normal physiological functions and human disease. Int $\mathrm{J}$ Biochem Cell Biol 2007;39(1):44-84.

van Praag $\mathrm{H}$. Neurogenesis and exercise: past and future directions. Neuromolecular Med. 2008;10(2):128-40.

van Praag H, Kempermann G, Gage FH. Running increases cell proliferation and neurogenesis in the adult mouse dentate gyrus. Nat Neurosci. 1999;2(3):266-70.

Vaynman S, Ying Z, Gomez-Pinilla F. Hippocampal BDNF mediates the efficacy of exercise on synaptic plasticity and cognition. Eur J Neurosci. 2004;20(10):2580-90.

Venkateshappa C, Harish G, Mythri RB, Mahadevan A, Bharath MM, Shankar SK. Increased oxidative damage and decreased antioxidant function in aging human substantia nigra compared to striatum: implications for Parkinson's disease. Neurochem Res. 2012;37(2):35869.

Vilela MG. Efeito do estresse cirúrgico e do estresse luminoso nos níveis séricos de leptina em ratas asultas wistar. [tese]. Minas Gerais: Universidade Federal de Minas Gerais; 2008.

Walker JM, Fowler SW, Miller DK, Sun AY, Weisman GA, Wood WG, Sun GY, Simonyi A, Schachtman TR. Spatial learning and memory impairment and increased locomotion in a transgenic amyloid precursor protein mouse model of Alzheimer's disease. Behav Brain Res. $2011 ; 222(1): 169-75$.

Waynforth HB, Flecknell PA. Experimental and surgical technique in the rat. 2nd ed. San Diego: Academic Press; 1992. 382 p. 
Winner B, Desplats P, Hagl C, Klucken J, Aigner R, Ploetz S, Laemke J, Karl A, Aigner L, Masliah E, Buerger E, Winkler J. Dopamine receptor activation promotes adult neurogenesis in an acute Parkinson model. Exp Neurol. 2009 Oct;219(2):543-52.

Wojtera M, Sikorska B, Sobow T, Liberski PP. Microglial cells in neurodegenerative disorders. Folia Neuropathol. 2005;43(4):311-21.

Wu SY, Wang TF, Yu L, Jen CJ, Chuang JI, Wu FS, Wu CW, Kuo YM. Running exercise protects the substantia nigra dopaminergic neurons against inflammation-induced degeneration via the activation of BDNF signaling pathway. Brain Behav Immun. 2011;25(1):135-46.

Yoon MC, Shin MS, Kim TS, Kim BK, Ko IG, Sung YH, Kim SE, Lee HH, Kim YP, Kim CJ. Treadmill exercise suppresses nigrostriatal dopaminergic neuronal loss in 6hydroxydopamine-induced Parkinson's rats. Neurosci Lett. 2007;423(1):12-7.

Zarow C, Lyness SA, Mortimer JA, Chui HC. Neuronal loss is greater in the locus coeruleus than nucleus basalis and substantia nigra in Alzheimer and Parkinson diseases. Arch Neurol. 2003;60(3):337-41.

Zigmond MJ, Cameron JL, Leak RK, Mirnics K, Russell VA, Smeyne RJ, Smith AD. Triggering endogenous neuroprotective processes through exercise in models of dopamine deficiency. Parkinsonism Relat Disord. 2009;15(S3):S42-S45.

Zigmond MJ, Abercrombie ED, Berger TW, Grace AA, Stricker EM. Compensations after lesions of central dopaminergic neurons: some clinical and basic implications. Trends Neurosci.1990;13(7):290-6. 
APÊNDICES 


\section{APÊNDICE A - Paper publicado no periódico Neuroscience com os dados do Capítulo 4}

Provided for non-commercial research and education use. Not for reproduction, distribution or commercial use.



(This is a sample cover image for this issue. The actual cover is not yet available at this time.)

This article appeared in a journal published by Elsevier. The attached copy is furnished to the author for internal non-commercial research and education use, including for instruction at the authors institution and sharing with colleagues.

Other uses, including reproduction and distribution, or selling or licensing copies, or posting to personal, institutional or third party websites are prohibited.

In most cases authors are permitted to post their version of the article (e.g. in Word or Tex form) to their personal website or institutional repository. Authors requiring further information regarding Elsevier's archiving and manuscript policies are encouraged to visit:

http://www.elsevier.com/copyright 


\section{BDNF RECEPTOR BLOCKADE HINDERS THE BENEFICIAL EFFECTS OF EXERCISE IN A RAT MODEL OF PARKINSON'S DISEASE}

\section{C. REAL, ${ }^{a *}$ A. F. B. FERREIRA, ${ }^{a}$ G. P. CHAVES-KIRSTEN, ${ }^{\mathrm{b}}$ A. S. TORRÃO, R. S. PIRES ${ }^{c}$ AND L. R. G. BRITTO ${ }^{a}$}

${ }^{a}$ Laboratory of Cellular Neurobiology, Department of Physiology and Biophysics, University of São Paulo, São Paulo, SP 05508-000, Brazil

${ }^{\mathrm{b}}$ Laboratory of Neuronal Communication, Department of Physiology and Biophysics, University of São Paulo, São Paulo, SP 05508-000, Brazil

${ }^{\mathrm{c}}$ Physical Therapy Graduate Program, City University of São Paulo, São Paulo, SP 03071-000, Brazil

Abstract-Physical exercise is known to produce beneficial effects to the nervous system. In most cases, brain-derived neurotrophic factor (BDNF) is involved in such effects. However, little is known on the role of BDNF in exercise-related effects on Parkinson's disease (PD). The aim of this study was to investigate the effects of intermittent treadmill exercise-induced behavioral and histological/neurochemical changes in a rat model of unilateral PD induced by striatal injection of 6-hydroxydopamine (6-OHDA), and the role of BDNF in the exercise effects. Adult male Wistar rats were divided into two main groups: (1) injection of K252a (a blocker of BDNF receptors), and (2) without BDNF receptor blockade. These groups were then subdivided into four groups: control (CLT), sedentary (SED, non-exercised with induction of $P D)$, exercised $3 \times /$ week during four weeks before and four weeks after the induction of $P D$ (EXB + EXA), and exercised $3 \times /$ week during four weeks after the induction of PD (EXA). One month after 6-OHDA injections, the animals were subjected to rotational behavioral test induced by apomorphine and the brains were collected for immunohistochemistry and immunoblotting assays, in which we measured BDNF and tyrosine hydroxylase (TH) in the substantia nigra pars compacta (SNc) and the striatum (caudate-putamen, $\mathrm{CPu}$ ). Our results showed a significant reduction of rotational asymmetry induced by apomorphine in the exercised parkinsonian rats. BDNF decreased in the SNc of the SED group, and exercise was able to revert that effect. Exercised groups exhibited

\footnotetext{
*Corresponding author. Tel: +55-11-3091-7242; fax: +55-11-3091 7426.

E-mail address: careal@icb.usp.br (C. C. Real)

Abbreviations: 6-OHDA, 6-hydroxydopamine; BDNF, brain-derived neurotrophic factor; $\mathrm{CPu}$, (caudate-putamen) - striatum; CLT, contro group - non-exercised rats with saline injection; EXB + EXA, rats that exercised 3 times per week during four weeks before and four weeks after the induction of the PD; EXA, rats that exercised 3 times per week after the induction of the PD; EXA, rats that exercised 3 times per week
during four weeks after the induction of the PD; K252a, BDNF receptor blocker; LPS, Lipopolysaccharide; PB, phosphate buffer; PD Parkinson's disease; SED, sedentary group - non-exercised rats with induction of PD; SNc, substantia nigra pars compacta; TH, tyrosine hydroxylase; TrkB, tyrosine kinase receptor B.
}

reduced damage to the dopaminergic system, detected as a decreased drop of TH levels in SNc and CPu. On the other hand, BDNF blockade was capable of substantially reducing $\mathrm{TH}$ expression postlesion, implying enhanced dopaminergic cell loss. Our data revealed that physical exercise is capable of reducing the damage induced by 6-OHDA, and that BDNF receptors are involved in that effect. (C) 2013 IBRO. Published by Elsevier Ltd. All rights reserved.

Key words: BDNF, 6-OHDA, Parkinson's disease, intermittent treadmill exercise, tyrosine hydroxylase, K252a.

\section{INTRODUCTION}

The etiology of Parkinson's disease (PD) is still not well understood. Postmortem examinations reveal a loss of the dopaminergic neurons in the substantia nigra pars compacta (SNc), and the consequent loss of dopamine in the striatum in the brains of PD patients (Blum et al., 2001). Research on the pathogenesis of the PD has been mainly based on the development of animal models that reproduce the loss of dopaminergic neurons in the SNc. The most used animal model of PD is the injection of dopamine analog 6-hydroxydopamine (6-OHDA) into the caudate-putamen (striatum - $\mathrm{CPu}$ ) or $\mathrm{SNc}$, and which selectively destroys catecholaminergic neurons, resulting in a decrease of dopamine levels into $\mathrm{CPu}$. That neurotoxin is found in the brains of PD patients (Jellinger et al., 1995) and the injection of $6-\mathrm{OHDA}$ in the central-lateral portion of the CPu is the animal model that most closely resembles the human disease (Tillerson et al., 2002; Schober, 2004). In addition, the intrastriatal injection is less aggressive than other injection sites, and produces a slow evolution of symptoms, which seems to be more suitable for studies that aim therapeutic strategies (Blandini et al., 2008). The analysis of tyrosine hydroxylase (TH) levels is usually employed to follow the progression of the neurodegenerative process in dopaminergic fibers and cell bodies. TH activity is also known to be progressively decreased following the loss of dopamine neurons of the SNc in PD patients (Haavik and Toska, 1998).

With an increasing life expectancy worldwide and hence the number of people with neurodegenerative diseases, several efforts have been made in an attempt to understand the etiology of PD and to develop therapeutic approaches. Exercise is a simple and widely practiced behavior that activates molecular and cellular cascades that support and maintain brain plasticity (Cotman and Berchtold, 2002), and is inversely related to neurodegenerative diseases. However, the extent of 


\section{Author's personal copy}

the lesion and the type of the exercise (voluntary or forced) may affect the degree of neuroprotection and behavioral improvement induced by physical exercise (Hirsch and Farley, 2009; Alonso-Frech et al., 2011).

Animal studies with PD models have shown that several plasticity processes are triggered by exercise and are involved in neuroprotection mechanisms, such as enhanced angiogenesis (Al-Jarrah et al., 2010), increased anti-inflammatory (Cadet et al., 2003) and decreased inflammatory responses (Wu et al., 2011), improved mitochondrial functions (Lau et al., 2011), and increased neurogenesis in the striatum (Tajiri et al., 2010) and in the SNc (Steiner et al., 2006). Plasticity responses improve the neurochemical deficits, especially TH levels, and both cognitive and motor symptoms (Sutoo and Akiyama, 2003; Cohen et al., 2003; Petzinger et al., 2007; Yoon et al., 2007; O'Dell et al., 2007; Tajiri et al., 2010; Lau et al., 2011; Wu et al., 2011). In models, clinical studies with PD patients have shown that exercise decreases the risk of PD (Chen et al., 2005), improves life quality (Herman et al., 2007), motor coordination (Fisher et al., 2008) and balance (Toole et al., 2000; Goodwin et al., 2008).

It is possible that the neuroprotective effects of exercise are promoted by neurotrophins, such as the brain-derived neurotrophic factor (BDNF). This neurotrophin has a critical role in cell differentiation, neuronal survival, migration, dendritic arborization, synaptogenesis, and synaptic plasticity, acting through tyrosine kinase receptor B (TrkB) (Cotman and Berchtold, 2002).

BDNF expression has been shown to be decreased in animal models of PD (Tajiri et al., 2010; Lau et al., 2011; Wu et al., 2011) and postmortem studies in humans with PD (Howells et al., 2000). Exercise, on the other hand, is able to restore BDNF levels in animals (Tajiri et al., 2010; Lau et al., 2011; Wu et al., 2011) and parkinsonian patients (Ahlskog, 2011). In vitro, BDNF has neuroprotective effects against the neurotoxicity induced by 6-OHDA (Stahl et al., 2011). An in vivo study demonstrated similar results, as Wu and collaborators (2011) showed that BDNF injection in the $\mathrm{CPu}$ of mice prior to the injection of lipopolysaccharide (LPS) promoted an improvement of TH levels similar to what was observed in the exercised group. On the other hand, enhanced TH deficits were observed after intracerebroventricular administration of a BDNF receptor blocker in exercised mice prior to the administration of LPS (Wu et al., 2011) as well as in TrkB knockout mice (Baydyuk et al., 2011).

The above-mentioned studies reinforce the idea that BDNF is involved in PD neuroprotection induced by exercise, although they may not be the ideal models to study therapeutic strategies in the early stages of PD. For example, intraperitoneal injections of LPS promote a quick systemic and intense inflammation that activates microglial response in the $\mathrm{SNc}$ and other brain regions (Dutta et al., 2008; Wu et al., 2011), resulting in a severe loss of $76 \%$ of the TH-positive cells (Wu et al., 2011).

Furthermore, there are no studies in the literature showing the beneficial effects of intermittent exercise in PD animal models. An intermittent exercise routine, as proposed by this study, seems more feasible to PD patients and nonathletes that normally exercise 3 or 4 times a week (Herman et al., 2007). The present exercise protocol may therefore be closer to the reality of PD patients.

The aim of this study was to investigate the possible effects of intermittent treadmill exercise-induced behavioral and histological/neurochemical changes in a rat model of unilateral PD induced by striatal injection of $6-\mathrm{OHDA}$, and the role of BDNF in these effects.

\section{EXPERIMENTAL PROCEDURES}

We used two different exercise interventions: (i) exercised before and after the induction of PD - to associate with the findings that physically active individuals have some protection against the occurrence of PD (Sasco et al., 1992; Chen et al., 2005), and (ii) exercised only after the induction of PD - to analyze if physical exercise has beneficial effects after disease is installed (Herman et al., 2007; Fisher et al., 2008). TH immunostaining and immunoblotting were used as indicators of neurodegeneration, and the role of BDNF was directly assessed by means of a TrkB receptor blocker (K252a). The apomorphine rotational test was also used as an indicator of the effectiveness of 6-OHDA and improvement in the behavior.

\section{Animals}

Adult male Wistar rats, supplied by the central animal facility of the Institute of Biomedical Sciences of the University of São Paulo, were used in this study. The animals were housed in groups of 3-4 animals per conventional cage, maintained at $23^{\circ} \mathrm{C} \pm 2$, in an inverted 12-h light/12-h dark cycle (lights off at $6 \mathrm{am}$ ), with free access to food and water.

Our study involved two main groups of subjects: (1) with intrastriatal injection of $\mathrm{K} 252 \mathrm{a}$ (an inhibitor of TrkB) to block BDNF actions (Kafitz et al., 1999); (2) without the BDNF receptor blockade. These groups were divided into four groups, totaling eight groups. Each group was composed of 10 animals.

(1) animals that received intrastriatal injections of saline and had not been through the treadmill exercise, and designated as controls (CLT and CLT + K252a). Those groups represent the sham-operated animals (Yoon et al., 2007).

(2) animals that received intrastriatal injections of 6-OHDA and had not been through the treadmill exercise, and designated as sedentary (SED and SED + K252a)

(3) animals that received intrastriatal injections of 6-OHDA and had been through the treadmill exercise 3 times per week during four weeks before and four weeks after the induction of PD, and designated as EXB + EXA and $E X B+E X A+K 252 a$

(4) animals that received intrastriatal injections of 6-OHDA and had been through the treadmill exercise 3 times per week during four weeks only after the induction of $P D$, and designated as EXA and EXA + K252a.

At 2 months of age the animals of the EXB + EXA group started the exercise protocol; at 3 months of age the animals received the injections (6-OHDA, saline and K252a), and the EXA group started the exercise protocol; at 4 months of age the animals were euthanized. Fig. 1 summarizes the research general outline. The experiments were carried out in accordance with the guidelines of the Brazilian College for Animal Experimentation (COBEA) and the animal care guidelines of the National Institutes of Health ( $\mathrm{NIH} / \mathrm{USA})$. All 


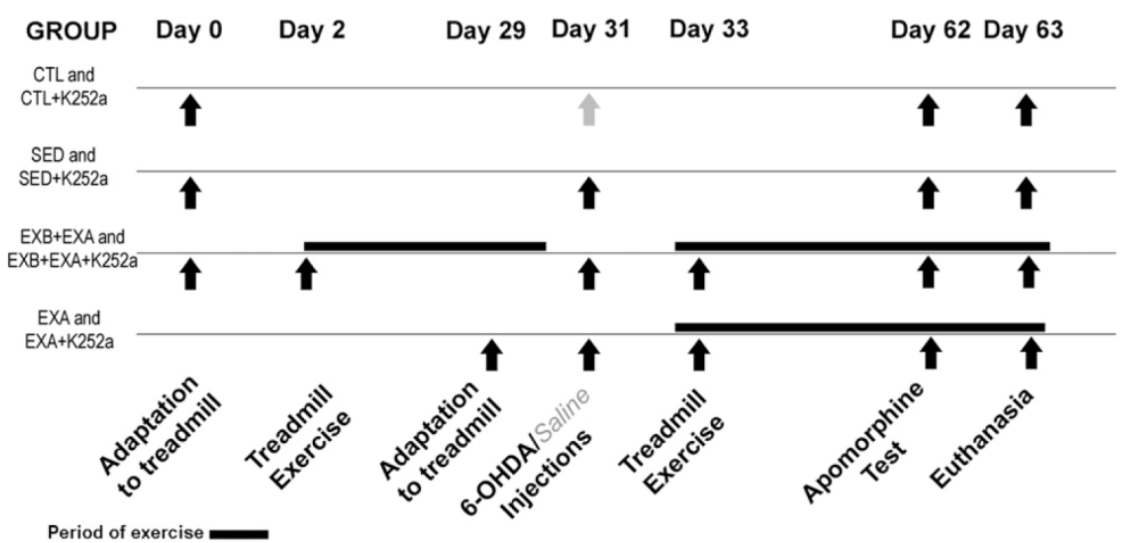

Fig. 1. Experimental design. Rats in the exercise group ran on a treadmill (3 days/week, 40 min). Control (CLT; CLT + K252a), Sedentary (SED SED + K252a), exercised 3 times per week during four weeks before and four weeks after the induction of PD (EXB + EXA $E X B+E X A+K 252 a$ ), exercised 3 times per week during four weeks after the induction of PD (EXA; EXA + K252a). The groups, named as $\mathrm{CLT}+\mathrm{K} 252 \mathrm{a}, \mathrm{SED}+\mathrm{K} 252 \mathrm{a}, \mathrm{EXB}+\mathrm{EXA}+\mathrm{K} 252 \mathrm{a}$, and EXA + K252a received a BDNF receptor block (K252a) together with 6-OHDA or saline injection. After behavioral evaluations, all rats were euthanized for immunoblotting or immunohistochemical analysis.

protocols were approved by the Ethics Committee for Animal Research of the Institute of Biomedical Sciences of the University of São Paulo (Protocol number 14/2009).

\section{Surgical procedure}

Rats with were anesthetized with 2,2,2-tribromoethanol at $2.5 \%$ $\left(1 \mathrm{ml} / 100 \mathrm{~g}-250 \mathrm{mg} / \mathrm{kg}\right.$ ip - Sigma $\left.{ }^{\circledR}\right)$ and placed in a stereotaxic apparatus. After craniotomy, with a micropipette connected to a microinfusion pump, two injections were performed $(0.5 \mu \mathrm{l}$ with $3 \mu \mathrm{g}$ of $6-\mathrm{OHDA}$ in saline and $0.3 \%$ ascorbic acid each) in the right $\mathrm{CPu}$ at the following coordinates: (1) AP: 0.0 , $L:-2.7$, and $V:-4.5 \mathrm{~mm}$, (2) AP: $-0.5, L:-3.2$, and $V$ : $-4.5 \mathrm{~mm}$ relative to bregma and ventral to the dura mater (Paxinos and Watson, 2005). The animals also received $1 \mu \mathrm{l}$ of K252a microsphere mix (prepared as described below) in each of the injection sites. After the end of the infusion, the micropipette was kept in the region infused for approximately $5 \mathrm{~min}$ to avoid reflux of the solution, and was then slowly removed from the brain. After finishing the infusion, the incision was sutured and the animals were kept isolated in cages.

\section{BDNF receptor blockade}

To block the BDNF receptors we used K252a (Tocris Bioscience, Bristol, UK) which is a non-selective antagonist of TrkB receptors known to block receptor autophosphorylation and inhibit downstream signaling involving the PI3-Akt pathway (Wu et al., 2011). The drug was injected into the CPu based on a protocol for microsphere injections described previously (Riddle et al. 1997; Lom and Cohen-Cory, 1999; Vaynman et al., 2004). We chose the microspheres to deliver $\mathrm{K} 252 \mathrm{a}$ in order to obtain slow retrograde transport to $\mathrm{SNc}$, thereby ensuring the release over 4 days (Riddle et al., 1997). The rhodamine fluorescent latex microspheres (Lumafluor, Naples, Florida, USA) were first incubated for $6 \mathrm{~h}$ at room temperature with an ion exchanger (10\% weight/vol - AG ${ }^{\circledR}$ 501-X8 Mixed Bed Resin (Bio-Rad Hercules, CA, USA). The microspheres were then incubated overnight in a mix of $1: 5$ (microspheres to $\mathrm{K} 252 \mathrm{a}$ ) at $4^{\circ} \mathrm{C}$. The drug was diluted in sterile water at a concentration of $46.8 \mathrm{ng} /$ $\mu \mathrm{l}$. The next day, the mixture was centrifuged at $100.000 \mathrm{~g}$ for $1.5 \mathrm{~h}$. The supernatant was discarded and the pellet was resuspended in sterile water at a concentration of $10 \%$. Groups receiving $\mathrm{K} 252 \mathrm{a}$ had $1 \mu \mathrm{l}$ of the drug injected together with
6-OHDA. A preliminary control experiment was performed in which we injected only microspheres into the $\mathrm{CPu}$. In this condition, microspheres showed no effects on any of the parameters analyzed here.

\section{Treadmill running}

Rats were exercised for 3 days a week on a treadmill (KT 3000 IMBRAMED) during their active period (Holmes et al., 2004; Salgado-Delgado et al., 2008) which helps decreasing the stress effects (Arida et al., 2011). The animals were adapted to the motorized treadmill by running for $15 \mathrm{~min}$ during two consecutive days $(6.7 \mathrm{~m} / \mathrm{min})$. Rats that refused running were excluded. The animals were then subjected to a moderate treadmill exercise protocol at a speed of $10 \mathrm{~m} / \mathrm{min}$ for $40 \mathrm{~min}$, running approximately $400 \mathrm{~m} /$ day as previously described (Real et al., 2010; Garcia et al., 2012). CLT and SED animals, which were considered as control groups, were placed in the cages near the treadmill to become familiarized with the surroundings. The treadmill exercise is extensively used because it is relatively simple and effective, permits training of several animals at the same time, and has the advantage of enabling both aerobic and anaerobic training. In this regard, this type of exercise forces the animals to run according to the researcher demands (time, duration, and intensity of the exercise running) (Arida et al., 2011).

\section{Behavioral testing}

Four weeks after unilateral 6-OHDA injections into the $\mathrm{CP}$ ( $n=10 /$ group), animals were subjected to the rotational behavioral test induced by apomorphine $(0.5 \mathrm{mg} / \mathrm{kg}$, s.c.). This test is widely used to quantify the degree of lesion in the PD model (Kirik et al., 1998). The behavior was assessed by using an automatic rotometer (Rota-Count 8 , Columbus Instruments) over a 30-min period. The net number of rotations was counted as the number of contralateral rotations (to the left side) less the number of ipsilateral rotations (to the right side). When the lesion is severe there is an increase in the asymmetric rotational behavior in the test (Yoon et al., 2007). One day after the behavioral test, the animals were sacrificed for the immunoblotting and immunohistochemical protocols. 


\section{Author's personal copy}

C. C. Real et al./ Neuroscience 237 (2013) 118-129

\section{Immunoblotting}

Rats were sacrificed by decapitation ( $n=5 /$ group), and the ventral midbrain/SNc (bregma -4.56 to -6.60 ) and the $\mathrm{CPu}$ (bregma +2.28 to -1.32 ) (Paxinos and Watson, 2005) were rapidly collected and homogenized at $4^{\circ} \mathrm{C}$ in an extraction buffer (Tris, pH 7.4, $100 \mathrm{mM}$; EDTA $10 \mathrm{mM}$; PMSF $2 \mathrm{mM}$ aprotinin $0.01 \mathrm{mg} / \mathrm{ml}$ ). The homogenates were subjected to centrifugation at $12,000 \mathrm{rpm}$ for $20 \mathrm{~min}$, and the protein concentration of the supernatant was determined using a protein assay (Bio-Rad, Hercules, CA). The material was stored in Laemmli buffer (Tris/ $\mathrm{HCl} 125 \mathrm{mM}, \mathrm{pH}$ 6.8; 2.5\% (p/v) SDS; $2.5 \%$ of 2 -mercaptoethanol (2-ME), $4 \mathrm{mM}$ of EDTA and $0.05 \%$ of Bromophenol Blue) (Laemmli, 1970) at $-70^{\circ} \mathrm{C}$

Samples from the homogenate containing $50 \mu \mathrm{g}$ protein were applied to $10 \%(\mathrm{TH})$ or $15 \%$ (BDNF) polyacrylamide gels containing sodium dodecyl sulfate and electrotransferred to nitrocellulose membranes using a Trans-Blot cell system (Bio-Rad). The nitrocellulose membranes were then blocked for at least $2 \mathrm{~h}$. After three washes of $10 \mathrm{~min}$ the membranes were incubated overnight at $4{ }^{\circ} \mathrm{C}$ with antibodies against TH, BDNF and $\beta$-actin. For $\mathrm{TH}$, we used a primary monoclonal mouse antiserum against TH (Chemicon, Temecula, CA, USA), which identifies a band of approximately $52 \mathrm{kDa}$. To analyze BDNF we used a rabbit monoclonal anti-BDNF (Chemicon, Temecula, CA, USA), which identifies a band of approximately $14 \mathrm{kDa}$ ('mature' BDNF, which binds with greatest affinity to TrkB, and predominantly supports neuronal survival) (Nagahara and Tuszynski, 2011). Monoclonal mouse anti- $\beta$-actin (Sigma, St. Louis, MO) was used in all experiments as an internal control (approximately $42 \mathrm{kDa}$ ).

Following three washes of 10 min each, membranes were incubated with anti-mouse or anti-rabbit peroxidase-conjugated secondary antibodies (1:10,000 - Amersham Biosciences, Little Chalfont, Buckinghamshire, United Kingdom). The specifically bound antibody was visualized using a chemiluminescence kit (ECL Kit; Amersham Biosciences). Finally, the blots were densitometrically analyzed with Scion Image 4.0.2 (Scion Corporation, Frederick, MD). The optical densities of the $\mathrm{TH}$ and BDNF bands were normalized in relation to the corresponding $\beta$-actin bands in each experiment. Subsequently, these data were used to evaluate protein levels in experimental animals in relation to the appropriate controls for each time point.

\section{Immunohistochemistry}

Other sets of rats ( $n=5 /$ group) were deeply anesthetized with ketamine $(5 \mathrm{mg} / 100 \mathrm{~g}$ of body weight, im) and xylazine ( $1 \mathrm{mg} / 100 \mathrm{~g}$ of body weight, im), and perfused through the left ventricle with phosphate-buffered saline and $4 \%$ paraformaldehyde in $0.1 \mathrm{M}$ phosphate buffer $(\mathrm{pH} 7.4, \mathrm{~PB})$. The brains were dissected out and postfixed for $4 \mathrm{~h}$. After this period, they were kept in a $30 \%$ sucrose solution in PB for at least $48 \mathrm{~h}$ for cryoprotection. Coronal sections $(30 \mu \mathrm{m})$ of the brain were obtained on a sliding microtome and collected in PB. Sections were stored at $4{ }^{\circ} \mathrm{C}$ until starting the immunohistochemical procedures.

For immunostaining, we used the same $\mathrm{TH}$ antibody described above for the immunoblotting procedure. The secondary antibody was a biotinylated donkey anti-mouse lgG (Jackson Laboratories, West Grove, PA, USA). Immunolabeling was conducted as previously described (Real et al., 2010). In short, the brain sections were incubated overnight at $22^{\circ} \mathrm{C}$ with a primary antibody solution containing $5 \%$ normal donkey serum in $0.3 \%$ Triton $\mathrm{X}-100$ in PB diluted $1: 250$ and with a secondary antibody solution diluted $1: 200$ for $2 \mathrm{~h}$. Afterward, the sections were processed with the $A B C$ Elite kit (Vector Labs, Burlingame, CA, USA) for $2 \mathrm{~h}$ and the labeling was developed with $0.05 \%$ diaminobenzidine tetrahydrochloride and $0.03 \%$ (final concentration) hydrogen peroxide in PB and intensified with $0.05 \%$ osmium tetroxide in water. Controls for the specificity of immunostaining were performed by the omission of the primary antibodies or their substitution with normal sera. No staining was obtained under either control condition. Three digital images from each of the five animals per group were acquired using a Nikon E1000 microscope (Melville, NY, USA) and Nikon DMX1200 digital camera (Nikon Imaging Software ACT-U), encompassing an area of $420,000 \mu \mathrm{m}^{2}$ of the SNc between bregmas -4.68 to -5.64 and the average of three areas of $2500 \mu \mathrm{m}^{2}$ of the CPu between bregmas 1.80 and -0.36 (5 sections/brain/structure). We analyzed the number of the $\mathrm{TH}$-positive cells in the $\mathrm{SNc}$ and the integrated density for $\mathrm{TH}$ staining in the $\mathrm{CPu}$ (Image $\mathrm{J}$, $\mathrm{NIH} / \mathrm{USA}$ ). The data were normalized in relation to the contro hemisphere.

\section{Statistical analysis}

Data were expressed as means \pm SEM (Graph Pad Prism 5) Data were statistically analyzed with two-way ANOVA. The Tukey post hoc test was used when appropriate; $p<0.05$ was adopted as the significance level (Statistica 11, StatSoft).

\section{RESULTS}

\section{Behavioral testing}

One month after 6-OHDA injections the behavioral testing showed changes in rotational behavior induced by apomorphine $[F(3,72)=17.577 ; p=0.000001]$. We have not observed any significant rotational asymmetric behavior in the control groups (CLT, $7 \pm 1$ turns; $\mathrm{CLT}+\mathrm{K} 252 \mathrm{a}, \quad 8 \pm 2$ turns) and exercised groups (EXB + EXA, $17 \pm 3$ turns; $\quad$ EXA, $33 \pm 2$ turns). However, the SED group and the exercised + K252atreated groups (EXB + EXA + K252a and EXA + $\mathrm{K} 252 \mathrm{a})$ exhibited an increase in the rotational asymmetry following apomorphine challenge when compared to the CLT group (SED, $84 \pm 4$ turns; SED + K252a, $103 \pm 11$ turns; EXB + EXA + K252a, $92 \pm 8$ turns; $\quad$ EXA + K252a, $109 \pm 11$ turns; $p=0.000123$ ) (Fig. 2).

\section{BDNF}

The immunoblotting data revealed that the relative protein levels of BDNF decreased in the SNc of the SED group $(0.43 \pm 0.08)$ when compared to the CLT group (ca. $57 \%, 1.00 \pm 0.12 ; p=0.0002$ ) and exercised groups $(E X B+E X A-$ ca. $88 \%, 1.13 \pm 0.05$; EXA - ca. $52 \%$, $0.90 \pm 0.09 ; \quad p=0.001) \quad[F(3,32)=22.284 ; \quad p=$ $0.0000001]$. A similar result was noted after K252a treatment in SED group $(0.59 \pm 0.05)$ in relation to other groups (CLT + K252a - ca. 41\%, $1.00 \pm 0.07$, $p=0.008 ; \quad$ EXB + EXA + K252a - ca. $37 \%$ $0.94 \pm 0.02, p=0.03 ; \quad E X A+\mathrm{K} 252 \mathrm{a}-$ ca. $43 \%$, $1.03 \pm 0.06, p=0.03$ ) (Fig. 3). No significant changes were observed after BDNF blockade $[F(1,32)=0.206$; $p=0.65]$. However, BDNF levels in the CPu did not change $[F(3,32)=0.65970 ; p=0.58]$ (Fig. 4).

\section{TH}

Neither the immunostaining nor the immunoblotting protocols have revealed differences of $\mathrm{TH}$ levels in 


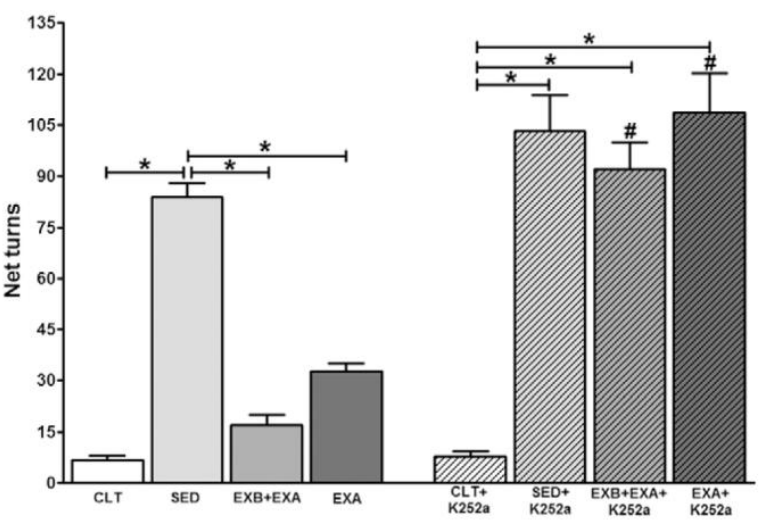

Fig. 2. The effects of treadmill exercise and BDNF receptor blockade on apomorphine-induced rotation in rats. Mean of the asymmetric rotations in each group. Note that exercise attenuated the behavior dysfunction. The BDNF receptor blocker, K252a, reverted the behavioral improvement. ${ }^{*} p<0.05$. "Point to statistical differences between each group of animals that received K252a and the corresponding group that did not receive the drug.



Fig. 3. Effects of treadmill running on BDNF levels in the substancia nigra pars compacta (SNc). Mean ratio of BDNF densitometry density data in relation to beta-actin, comparing the experimental side between the groups. The images represent typical immunoblots in each condition. Note that the SNc BDNF levels decrease in sedentary rats, and didn't change after the blockaded of the BDNF receptors. ${ }^{*} p<0.05$.

exercised, non-parkinsonian rats in relation to sedentary, non-parkinsonian rats. In addition, the contralateral (control) side of the brain of exercised, parkinsonian rats showed $\mathrm{TH}$ levels that were similar to those of sedentary, parkinsonian rats (data not shown). Although this indicates a lack of effect of the present intermittent protocol of exercise on the nigrostriatal system, training appeared to induce important neuroprotective effects in 6-OHDA-injected animals, as described below.

SNc. TH was detectable in both structures analyzed, but $\mathrm{TH}$ staining showed different responses for different groups and structures. The CLT group exhibited no changes of $\mathrm{TH}$ staining, whereas, the groups that received 6-OHDA revealed different responses.

The digital images of SNc coronal sections illustrate the $\mathrm{TH}$ changes that occur in the different groups after the 6-OHDA injection (Fig. 5). There was a $\mathrm{TH}$ decrease in both SED groups (SED - $56 \pm 4$, ca. $44 \%$, $p=0.0001 ; \quad$ SED + K252a - $31 \pm 1$, ca. $69 \%$; $p=0.0001)$ when compared to control groups (CLT $100 \pm 2, \quad C L T+K 252 a, \quad 100 \pm 1)$. Therefore, the decrease in the SED + K252a group was more intense than in the SED group (ca.45\%; $p=0.0001$ ). In the 


\section{Author's personal copy}

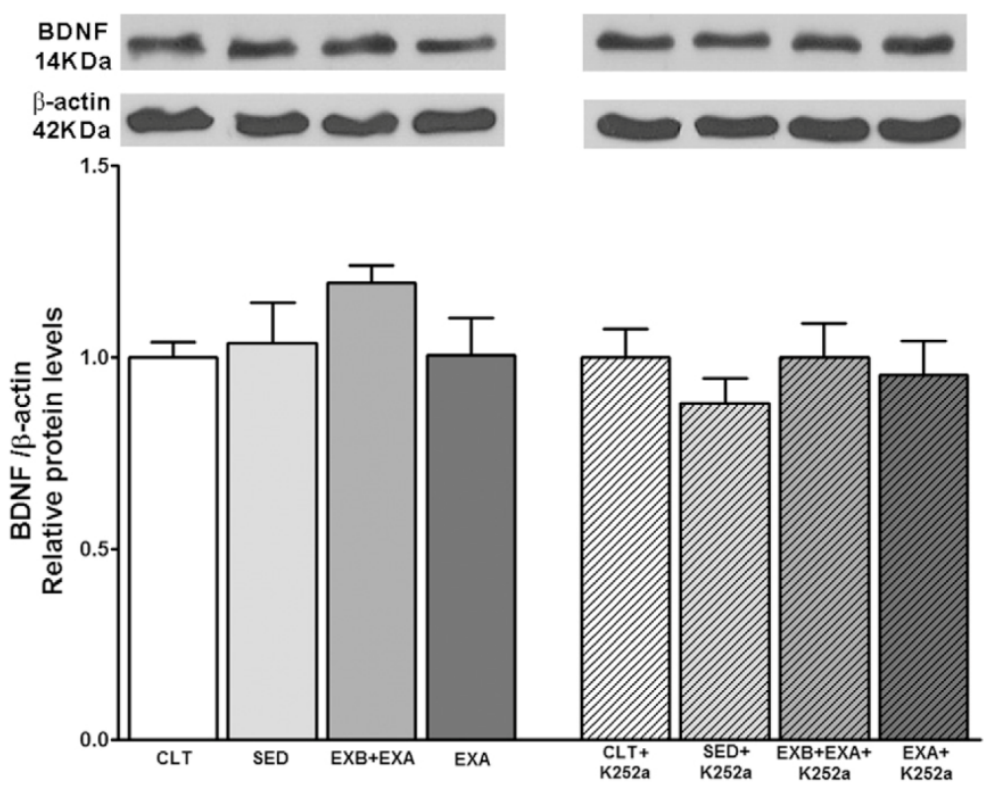

Fig. 4. Effects of treadmill running on BDNF levels in the striatum (CPu). Mean ratio of BDNF densitometry density data in relation to beta-actin, comparing the experimental side between the groups. The images represent typical immunoblots in each condition. Note that the CPu BDNF didn't change after 6-OHDA injection and with the blockade of BDNF receptors.

EXB + EXA group $(77 \pm 2)$ the TH-positive cells decreased after 6-OHDA injection in relation to the CLT group (ca. $23 \%, p=0.0001$ ), but increased in relation to the SED group (ca. $27 \%, 56 \pm 4, p=0.0005$ ). The addition of K252a promoted an increased in the loss of such cells (EXB + EXA + K252a:28 \pm 4$)$ when compared to the CLT + K252a group (ca. 72\%, $100 \pm 1 ; p=0.0001$ ) and the EXB + EXA group (ca. $64 \% ; 77 \pm 2, p=0.0001)$. The EXA group $(81 \pm 4)$ showed a decrease in the percentage of number of the TH-positive cells when compared to the CLT group $(100 \pm 2$, ca. $19 \% ; p=0.0003)$, but an increase in relation to the SED group (ca. 31\%, $56 \pm 4$ $p=0.0001$ ). When we added K252a, the TH decrease was enhanced by about $47 \%$ (EXA + K252a: $38 \pm 4$ $p=0.0001)[F(3,32)=32.386 ; p=0.000001]$ (Fig. 6).

Immunoblotting data revealed that $\mathrm{TH}$ levels in the SNc decreased only in the SED group $(0.46 \pm 0.04)$ when compared to the other groups (CLT - ca. $54 \%$, $1.00 \pm 0.04, p=0.0004 ;$ EXB + EXA - ca. 59\%, $1.13 \pm 0.12, p=0.0001 ; \mathrm{EXA}-$ ca. $47 \%, 0.87 \pm 0.07$ $p=0.009$ ). On the other hand, when we added K252a, all groups that received 6-OHDA showed decreases of $\mathrm{TH}$ levels (SED + K252a - ca.42\%, $0.58 \pm 0.10$, $p=0.006 ;$ EXB + EXA + K252a - ca. $38 \%, 0.62 \pm$ $0.07 ; p=0.01 ; \mathrm{EXA}+\mathrm{K} 252 \mathrm{a}-$ ca. $45 \%, 0.55 \pm 0.07$; $p=0.003)[F(3,32)=7.6592 ; p=0.0005]$ (Fig. 7).

Striatum. TH staining in the CPu revealed changes in the different groups after 6-OHDA injections (Fig. 8). The relative optical density of $\mathrm{TH}$ staining exhibited a decrease in the SED group (ca. 55\%, $0.45 \pm 0.02$, $p=0.0001$ ), and in the EXA group (ca. $32 \%$, $0.68 \pm 0.03 ; p=0.0001)$ when compared to the CLT group. But when comparing the EXA group with the SED group we noticed an increase of the TH levels (ca. $34 \%, p=0.0001)$. Moreover, when we added K252a, the $\mathrm{TH}$ staining decreased in all groups that received $6-O H D A \quad$ (SED + K252a - ca. 44\%, $0.56 \pm 0.02$; $p=0.0001 ; \quad \mathrm{EXB}+\mathrm{EXA}+\mathrm{K} 252 \mathrm{a}-$ ca. $47 \%$, $0.53 \pm 0.04, p=0.0001 ;$ EXA + K252a - ca. $35 \%$, $0.65 \pm 0.01, p=0.0001)$ when compared to the $\mathrm{CLT}+\mathrm{K} 252 \mathrm{a}$ group $[F(3,32)=47.436 ; p=0.000001]$ (Fig. 9).

In the $\mathrm{CPu}$, the immunoblotting results were similar to those obtained for the SNc. The TH levels decreased in the SED group $(0.24 \pm 0.03)$ when compared to the other groups (CLT - ca. 76\%, $1.00 \pm 0.11, p=0.0001$; EXB + EXA - ca. $80 \%, 1.19 \pm 0.10, p=0.0001$; EXA - ca. $73 \%, 0.90 \pm 0.05, p=0.0001)$. The groups that received $\mathrm{K} 252 \mathrm{a}$ and 6 -OHDA showed a decrease in the $\mathrm{TH}$ levels when compared to the CLT + K252a group $(1.00 \pm 0.02)($ SED + K252a - ca. $66 \%, 0.34 \pm 0.07$, $p=0.0001 ; \quad \mathrm{EXB}+\mathrm{EXA}+\mathrm{K} 252 \mathrm{a}-$ ca. $37 \%$, $0.63 \pm 0.04, p=0.0007 ; \mathrm{EXA}+\mathrm{K} 252 \mathrm{a}-$ ca. $54 \%$, $0.46 \pm 0.06, p=0.0001)$. Furthermore, the exercised groups that received $\mathrm{K} 252 \mathrm{a}$ showed enhanced reductions of $\mathrm{TH}$ when compared to the groups that did not receive the blocker $(\mathrm{EXB}+\mathrm{EXA}+\mathrm{K} 252 \mathrm{a}-\mathrm{ca}$. $37 \% ; \quad$ EXA + K252a - ca. $54 \% ; \quad p=0.0007)$ $[F(3,32)=10.029 ; p=0.00008]$ (Fig. 10).

\section{DISCUSSION}

The purpose of this study was to investigate the impact of intermittent exercise protocols on the 6-OHDA model of $\mathrm{PD}$ and to analyze the possible involvement of BDNF, a neurotrophin that has a critical role in the mechanisms 


\section{Tyrosine Hydroxylase - SNc}

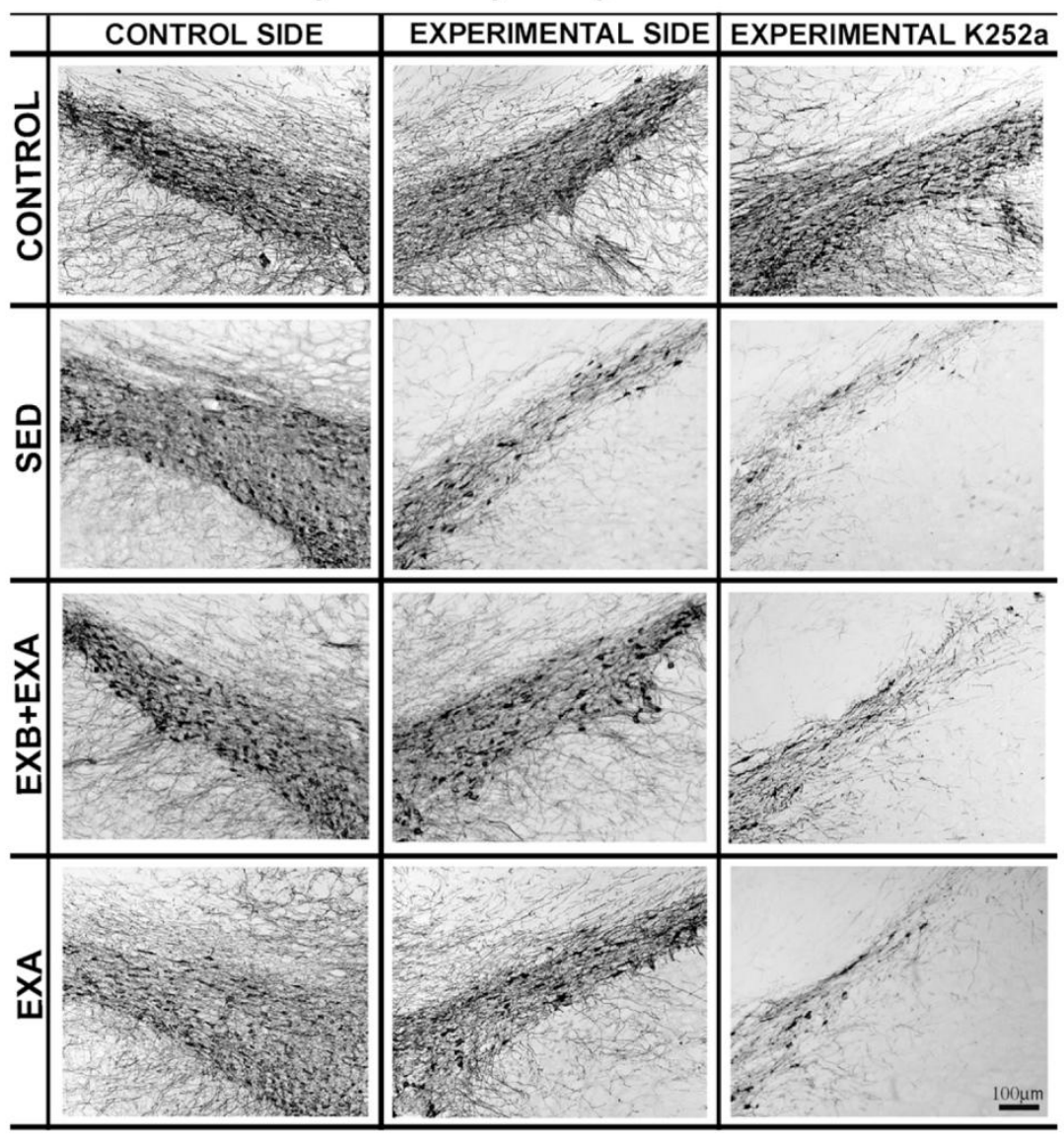

Fig. 5. Effects of treadmill running in the substantia nigra pars compacta (SNc). Digital images of coronal sections through the SNc stained for TH. Approximate bregma plane, $+5.2 \mathrm{~mm}$. Note that the TH reduction observed after 6-OHDA in the SED rats is attenuated after exercise. The BDNF receptor blocker, K252a, reverted the protective effect of exercise against 6-OHDA-induced dopaminergic neuron loss.

of exercise-induced neuroprotection (Blum et al., 2001; Mattson et al., 2008; Nguyen et al. 2008; Zigmond et al., 2009; Tajiri et al., 2010; Wu et al., 2011). In general, the intermittent treadmill exercise employed in our study has produced an increase of BDNF levels in parkinsonian-exercised rats, independent of the BDNF receptor blockade. There was a clear neuroprotective effect of exercise after 6-OHDA lesions, as the TH levels in the $\mathrm{CPu}$ and the $\mathrm{SNc}$ decreased less after training This effect was eliminated after BDNF receptor blockade with K252a. In addition, behavioral testing led to the same conclusion.

Several protocols of physical exercise have been used to explore its effects on brain function and its possible therapeutic functions in brain disorders, such as PD. However, the results found in the literature are controversial due to the variety of used protocols, such as different types of activities, intensity and frequency of exercise (Arida et al., 2011), and therefore many questions remain unanswered. Nevertheless, there are no studies in the literature showing the beneficial effects of intermittent exercise in PD animal models, and the BDNF involvement in such effects.

Some of the studies that showed effects of continuous exercise on PD models found attenuated dopamine depletion in the $\mathrm{CPu}$ and $\mathrm{SNc}$, neuroprotection of dopaminergic cells (Yoon et al., 2007; Petzinger et al., 2007; Tajiri et al., 2010; Lau et al., 2011), and recovery of the motor functions, as shown by the motor behavior induced by apomorphine (Kirik et al., 1998; Yoon et al., 2007) or amphetamine (Tajiri et al., 2010). Treadmill running at 5 days/week during 18 weeks decreases the loss of dopaminergic cells, increases dopamine and its transporter expression, and consequently improves balance and motor coordination (Lau et al., 2011). Moreover, another study showed that running wheel exercise during 2.5 weeks before intracerebral 6-OHDA infusions and continuing for up to 4 weeks postoperatively enhances recovery from nigrostriatal dopamine injury without inducing neuroprotection (O'Dell et al., 2007). Thus, there is agreement on the fact that exercise improves the motor behavior, but the protection 


\section{Author's personal copy}

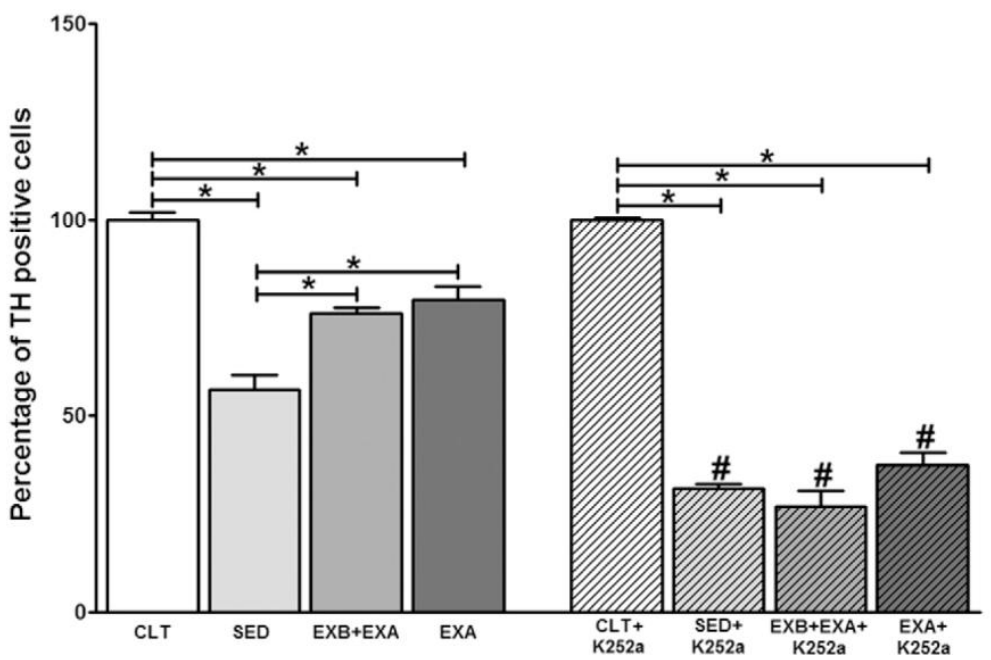

Fig. 6. Semi-quantitative analysis of TH staining in the substancia nigra pars compacta (SNc). The data depict the percentage of TH-positive cells in the experimental side in relation to the control side. The BDNF receptor blocker, K252a, reverted the protective effect of exercise against 6 OHDA-induced dopaminergic neuron loss. ${ }^{*} p<0.05$; ${ }^{\#}$ point to statistical differences between each group of the animals that received K252a and the corresponding group that did not receive the drug.

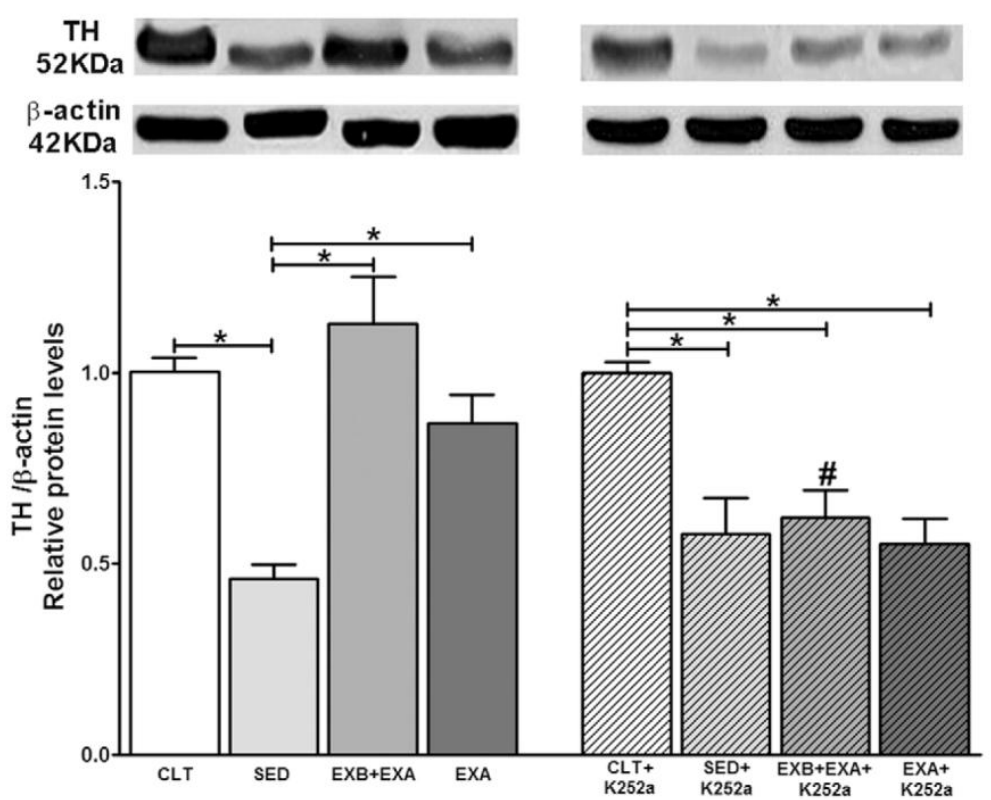

Fig. 7. Effects of treadmill running on TH levels in the substantia nigra pars compacta (SNc). Mean ratio of TH densitometry density data in relation to beta-actin, comparing the experimental side between the groups. The images represent typical immunoblots in each condition. The BDNF receptor blocker, K252a, reverted the protective effect of exercise against 6 -OHDA-induced dopaminergic neuron loss. ${ }^{*} p<0.05$; ${ }^{\#}$ point to statistical differences between each group of the animals that received $\mathrm{K} 252 \mathrm{a}$ and the corresponding group that did not receive the drug.

of dopaminergic neurons from the neurotoxin is controversial (Zigmond et al., 2009). In both of our intermittent exercise protocols (EXB + EXA and EXA) we noted a neuroprotection of the dopaminergic cells, with a higher number of TH-positive cells in the SNc of the exercised groups. This neuroprotection process resulted in higher $\mathrm{TH}$ levels in the $\mathrm{CPu}$, which were similar to the CLT group. Besides the improvement of
TH levels, our behavioral tests showed a decrease in the asymmetric net turns in the exercised groups $(E X B+E X A$ and EXA) in relation to the SED group. Thus, the behavioral results corroborate the neurochemistry findings, as also demonstrated in another study (Yoon et al., 2007).

Thus, our study shows for the first time the neuroprotective effect of intermittent treadmill exercise 


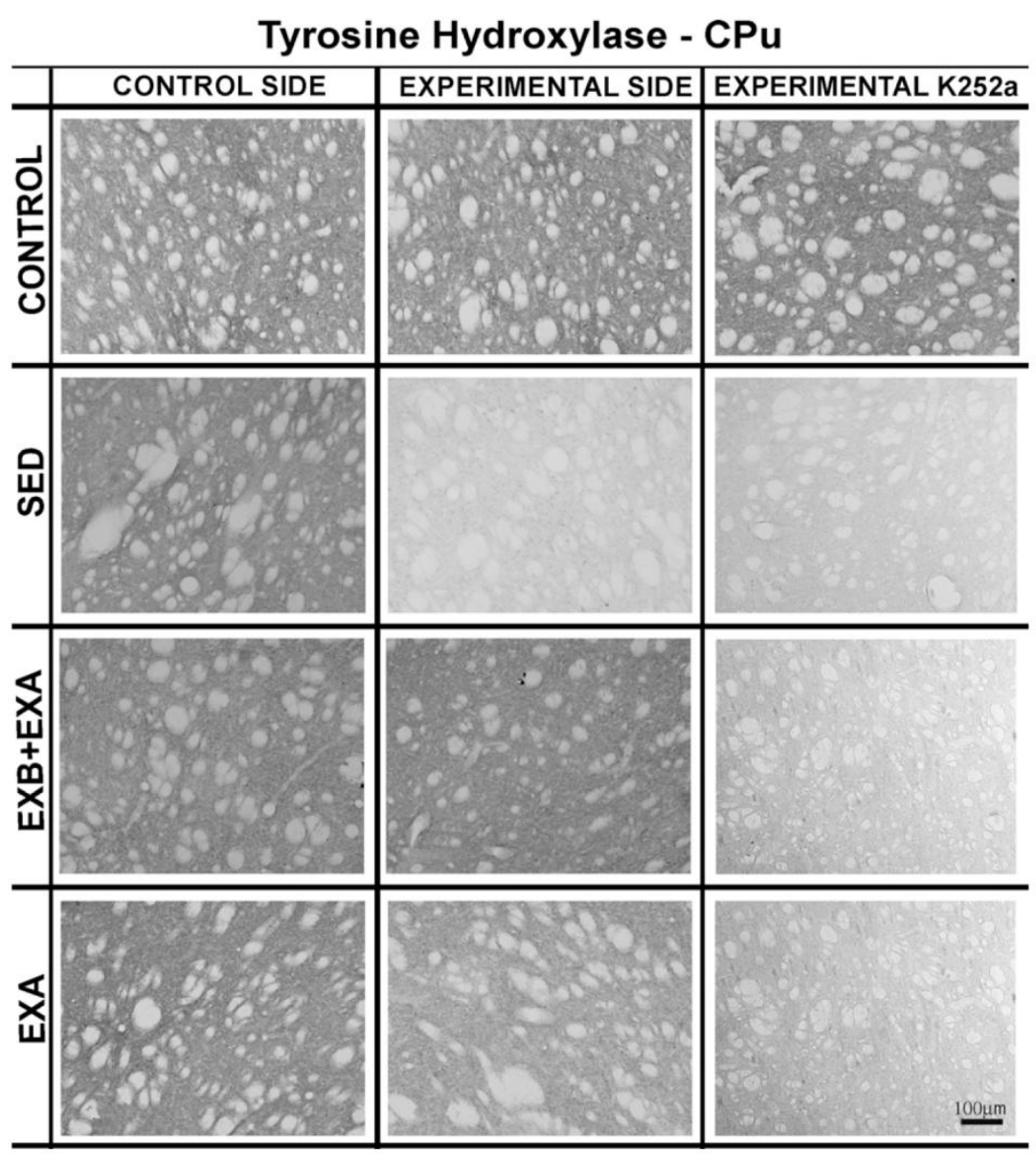

Fig. 8. Effects of treadmill running upon $\mathrm{TH}$ staining in the striatum $(\mathrm{CPu})$. Approximate bregma plane, $+1.56 \mathrm{~mm}$. Note that the $\mathrm{TH}$ reduction observed after 6-OHDA in the SED rats is attenuated after exercise. The BDNF receptor blocker, K252a, reverted the protective effect of exercise against 6-OHDA-induced dopaminergic neuron loss.

both in behavioral and neurochemical responses, which adds to the data obtained with the continuous exercise studies (Yoon et al., 2007; Petzinger et al., 2007; Tajiri et al., 2010; Lau et al., 2011). Although the data for continuous and intermittent exercise protocols are similar, we should emphasize that the intermittent exercise protocol could be more beneficial than continuous exercise, in addition to being closer to the exercise protocols undertaken in PD patients (Herman et al., 2007). Also, it should be stressed that we could not find any positive effects on TH levels in exercisedonly animals, as previously demonstrated with a continuous exercise protocol (Yoon et al., 2007).

Another interesting point relates to the different results between the two exercised groups. The EXB + EXA group showed better results in the TH CPu levels when compared to the EXA group. The EXB + EXA group exhibited a decrease of TH-positive cell numbers in the $\mathrm{SNc}$, but maintained levels of $\mathrm{TH}$ in the $\mathrm{CPu}$, and showed reduced motor symptoms. Thus, we can suggest that when the EXB + EXA group received the neurotoxin, the nervous system had already been protected by mechanisms that are activated by exercise, such as activation of endogenous antioxidant systems, increase of BDNF actions (Blum et al., 2001; Devi and Kiran, 2004; Mattson et al., 2008), and decrease of apoptosis (Mocchetti et al., 2007). Moreover, it is possible that when the EXA group started the intermittent treadmill exercise, the 6-OHDA had possibly initiated mechanisms of cell death, which could not be completely reverted by treadmill exercise. Zigmond and collaborators (2009) reviewed that exercise may not actually protect dopaminergic cells, but may allow remaining dopaminergic cells, as well as other components of the basal ganglia circuitry, to enhance their responsiveness to dopamine and/or compensate for the dopaminergic neurons that have been lost. There may be an increase of dopamine synthesis and release from residual neurons in the 6-OHDA model of PD.

In view of the beneficial effects of intermittent treadmill exercise we analyzed the BDNF levels, which are involved with several beneficial effects of exercise to nervous system (Blum et al., 2001; Mattson et al., 2008; Nguyen et al. 2008; Zigmond et al., 2009; Tajiri et al., 


\section{Author's personal copy}



Fig. 9. Semi-quantitative analysis of TH staining in the striatum (CPu). Mean ratio of the relative TH optical density in the experimental side in relation to the control side. The BDNF receptor blocker, K252a, blocks the protective effect of exercise against 6-OHDA-induced dopaminergic neuron loss. ${ }^{*} p<0.05$; ${ }^{\#}$ point to statistical differences between each group of the animals that received $\mathrm{K} 252 \mathrm{a}$ and the corresponding group that did not receive the drug.
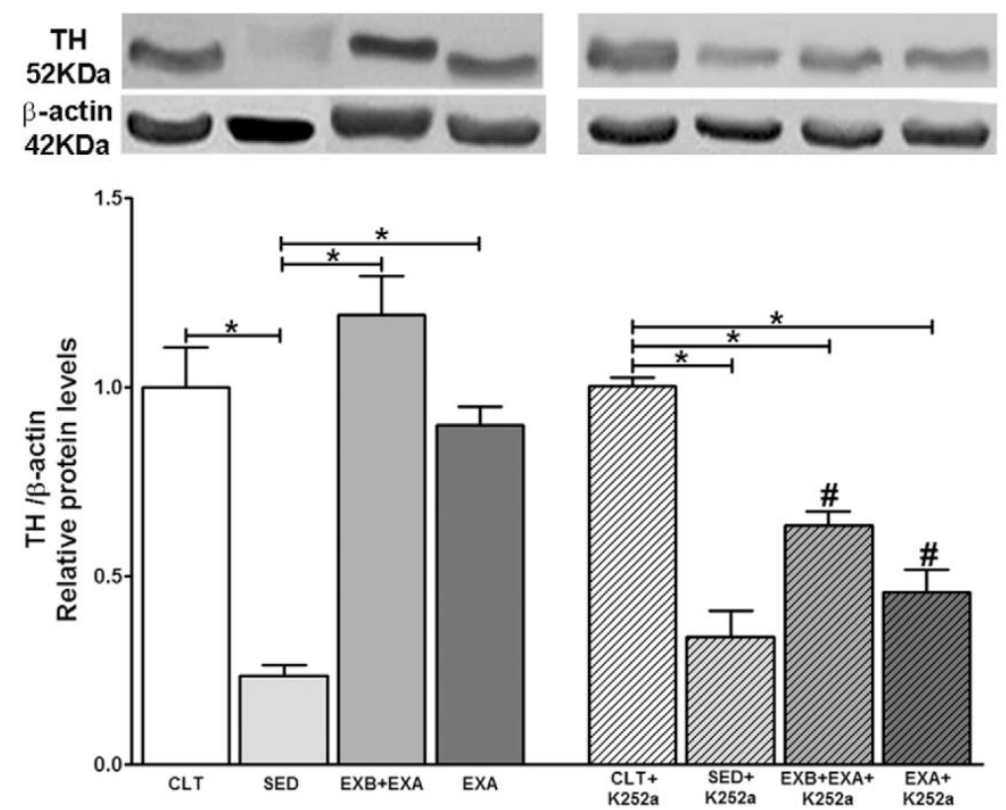

Fig. 10. Effects of treadmill running on TH levels in the striatum $(\mathrm{CPu})$. Mean ratio of $\mathrm{TH}$ densitometry density data in relation to beta-actin comparing the experimental side between the groups. The images represent typical immunoblots in each condition. The BDNF receptor blocker, K252a, reverted the protective effect of exercise against 6-OHDA-induced dopaminergic neuron loss. ${ }^{*} p<0.05$; ${ }^{\#}$ point to statistical differences between each group of the animals that received K252a and the corresponding group that did not receive the drug.

2010; Wu et al., 2011). The BDNF levels were revealed to be restored in the SNc, to a level similar to the CTL group, in the same groups in which we noticed an exerciserelated improvement of the $\mathrm{TH}$ levels and motor behavior, namely EXB + EXA and EXA. Moreover, there were no changes of neurotrophin levels in the $\mathrm{CPu}$. These findings suggest that BDNF indeed participates in the neuroprotective effects of exercise.
The increase in the BDNF levels in the SNc of exercised groups confirms that treadmill exercise promotes changes in the BDNF levels, which can activate TrkB-dependent mechanisms that are related to survival of nigrostriatal dopaminergic neurons (Baydyuk et al., 2011; Wu et al., 2011). Examples of such actions are the inhibition of apoptosis-mediated cell death and neurotoxin-induced degeneration of dopaminergic 
neurons (Binder and Scharfman, 2004). BDNF also activates the signaling pathway that modulates the transcription factor NFkB, which, in turn, induces the expression of antioxidant enzymes and anti-apoptotic proteins (Mattson et al., 2008). Our findings agree with other studies with PD models which showed that BDNF levels are very important for cell protection and for maintaining the TH expression (Tajiri et al., 2010), especially in the SNc (Lau et al., 2011). The BDNF signaling via TrkB receptor is recognizably important for the survival of dopaminergic neurons (Baydyuk et al., 2011).

To confirm that BDNF is involved with exerciseinduced neuroprotection in the present model, we injected K252a in the CPu to block the BDNF signaling via TrkB receptor. After BDNF receptor blockade the TH levels significantly decreased even in the exercised groups (EXB + EXA + K252a and EXA + K252a), without changes in the BDNF levels. These findings correlated to the worsening of the motor activity as observed with the apomorphine test (asymmetric net turns similar to SED and SED + K252a groups). Thus, we can suggest that the blockade of BDNF-TrkB signaling is involved with worsened neuroprotective effects of exercise after K252a injection.

Decreased TH levels have been detected in exercised mice that received LPS to induce dopaminergic cell death when associated to prior BDNF receptor blockade (Wu et al., 2011). Although our results corroborate with those findings, the intraperitoneal injections of LPS used in that study promote a quick inflammation in the SNc and other brain regions (Blum et al., 2001), whereas the 6-OHDA PD animal model represents a selective and less aggressive dopaminergic cell death process (Tillerson et al., 2002; Schober, 2004).

Similar effects of exercise have also been described in humans. Clinical findings indicate that exercise improves gait, mobility, and quality of life of patients with PD, decreasing the risk of falls. Exercise training may promote a more stable walking pattern in patients with $\mathrm{PD}$ and an intervention program that includes long-term treadmill walking is apparently able to restore rhythmicity (Herman et al., 2007) and equilibrium of parkinsonian patients (Toole et al., 2000). Perhaps the clinical improvement observed in PD patients is due to the normalization of the corticomotor excitability promoted by exercise in early PD (Fisher et al., 2008). In addition to the clinical improvements, physical activity increases serum BDNF, which cross the blood-brain barrier (Ahlskog, 2011), and may decrease the PD risk (Sasco et al., 1992; Chen et al., 2005), suggesting that exercise indeed exerts neuroprotective effects.

\section{CONCLUSION}

In summary, we showed in this study that intermittent exercise training can lead to improvement of the dopaminergic system and recovery of motor behavior in 6-OHDA-injected rats. We also demonstrated that those beneficial effects seem to involve the BDNF-TrkB system as a major neuroprotective system.
Acknowledgments-This study was supported by FAPESP, CAPES, University of São Paulo - NAPNA and CNPq (Brazil). Thanks are also due to Adilson S. Alves for technical assistance. C.C.R., A.F.B.F. and G.P.C.K. were the recipients of fellowships from FAPESP.

\section{REFERENCES}

Ahlskog JE (2011) Does vigorous exercise have a neuroprotective effect in Parkinson disease? Neurology 77(3):288-294.

Al-Jarrah M, Jamous M, Al Zailaey K, Bweir SO (2010) Endurance exercise training promotes angiogenesis in the brain of chronic/progressive mouse model of Parkinson's disease. NeuroRehabilitation 26(4):369-373.

Alonso-Frech F, Sanahuja JJ, Rodriguez AM (2011) Exercise and physical therapy in early management of Parkinson disease. Neurologist(6 Suppl. 1):S47-S53.

Arida RM, Scorza FA, Gomes da Silva S, Cysneiros RM, Cavalheiro EA (2011) Exercise paradigms to study brain injury recovery in rodents. Am J Phys Med Rehabil 90(6):452-465.

Baydyuk M, Nguyen MT, Xu B (2011) Chronic deprivation of TrkB signaling leads to selective late-onset nigrostriatal dopaminergic degeneration. Exp Neurol 228(1):118-125.

Binder DK, Scharfman HE (2004) Brain-derived neurotrophic factor. Growth Factors 22(3):123-131.

Blandini F, Armentero MT, Martignoni E (2008) The 6-hydroxydopamine model: news from the past. Parkinsonism Relat Disord 14: S124-S129.

Blum D, Torch S, Lambeng N, Nissou M, Benabid AL, Sadoul R, Verna JM (2001) Molecular pathways involved in the neurotoxicity of 6-OHDA, dopamine and MPTP: contribution to the apoptotic theory in Parkinson's disease. Prog Neurobiol 65:135-172.

Cadet P, Zhu W, Mantione K, Rymer M, Dardik I, Reisman S, Hagberg S, Stefano GB (2003) Cyclic exercise induces antiinflammatory signal molecule increases in the plasma of Parkinson's patients. Int J Mol Med 12(4):485-492.

Chen $\mathrm{H}$, Zhang SM, Schwarzschild MA, Hernán MA, Ascherio A (2005) Physical activity and the risk of Parkinson disease. Neurology 64:664-669.

Cohen AD, Tillerson JL, Smith AD, Schallert T, Zigmond MJ (2003) Neuroprotective effects of prior limb use in 6-hydroxydopaminetreated rats: possible role of GDNF. J Neurochem 85:299-305.

Cotman CW, Berchtold NC (2002) Exercise: a behavioral intervention to enhance brain health and plasticity. Trends Neurosci 25(6):295-301.

Devi SA, Kiran TR (2004) Regional responses in antioxidant system to exercise training and dietary vitamin $\mathrm{E}$ in aging rat brain. Neurobiol Aging 25:501-508.

Dutta G, Zhang P, Liu B (2008) The lipopolysaccharide Parkinson's disease animal model: mechanistic studies and drug discovery. Fundam Clin Pharmacol 22:453-464.

Fisher BE, Wu AD, Salem GJ, Song J, Lin CH, Yip J, Cen S, Gordon J, Jakowec M, Petzinger GM (2008) The effect of exercise training in improving motor performance and corticomotor excitability in people with early Parkinson's disease. Arch Phys Med Rehabil 89:1221-1229.

Garcia PC, Real CC, Ferreira AF, Alouche SR, Britto LR, Pires RS (2012) Different protocols of physical exercise produce different effects on synaptic and structural proteins in motor areas of the rat brain. Brain Res 1456:36-48.

Goodwin VA, Richards SH, Taylor RS, Taylor AH, Campbell JL (2008) The effectiveness of exercise interventions for people with Parkinson's disease: a systematic review and metaanalysis. Mov Disord 23(5):631-640.

Haavik J, Toska K (1998) Tyrosine hydroxylase and Parkinson's disease. Mol Neurobiol 16(3):285-309.

Herman T, Giladi N, Gruendlinger L, Hausdorff JM (2007) Six weeks of intensive treadmill training improves gait and quality of life in 


\section{Author's personal copy}

patients with Parkinson's disease: a pilot study. Arch Phys Med Rehabil 88:1154-1158.

Hirsch MA, Farley BG (2009) Exercise and neuroplasticity in persons living with Parkinson's disease. Eur J Phys Rehabil Med 45(2):215-229.

Holmes MM, Galea LA, Mistlberger RE, Kempermann G (2004) Adult hippocampal neurogenesis and voluntary running activity circadian and dose dependent effects. J Neurosci Res 76:216-222.

Howells DW, Porritt MJ, Wong JY, Batchelor PE, Kalnins R, Hughes AJ, Donnan GA (2000) Reduced BDNF mRNA expression in the Parkinson's disease substantia nigra. Exp Neurol 166(1):127-135.

Jellinger K, Linert L, Kenzl E, Herlinger E, Youdim MB (1995) Chemical evidence for 6-hydroxydopamine to be an endogenous toxic factor in the pathogenesis of Parkinson's disease. J Neural Transm Suppl 46:297-314.

Kaftz KW, Rose CR, Thoenen H, Konnerth A (1999) Neurotrophinevoked rapid excitation through TrkB receptors. Nature 401:918-921.

Kirik D, Rosenblad C, Björklund A (1998) Characterization of behavioral and neurodegenerative changes following partial lesions of the nigrostriatal dopamine system induced by intrastriatal 6-hydroxydopamine in the rat. Exp Neurol 152(2):259-277.

Laemmli UK (1970) Cleavage of structural proteins during the assembly of the head of bacteriophage T4. Nature 227:680-685.

Lau YS, Patki G, Das-Panja K, Le WD, Ahmad SO (2011) Neuroprotective effects and mechanisms of exercise in a chronic mouse model of Parkinson's disease with moderate neurodegeneration. Eur J Neurosci 33:1264-1274.

Lom B, Cohen-Cory S (1999) Brain-derived neurotrophic factor differentially regulates retinal ganglion cell dendritic and axonal arborization in vivo. J Neurosci 19:9928-9938.

Mattson MP, Gleichmann M, Cheng A (2008) Mitochondria in neuroplasticity and neurological disorders. Neuron 60:748-766.

Mochetti I, Bachis A, Nosheny RL, Tanda G (2007) Brain-derived neurotrophic factor expression in the substantia nigra does not change after lesions of dopaminergic neurons. Neurotox Res 12:135-143.

Nagahara AH, Tuszynski MH (2011) Potential therapeutic uses of BDNF in neurological and psychiatric disorders. Nat Rev Drug Discov 10(3):209-219.

Nguyen N, Lee SB, Lee YS, Lee KH, Ahn JY (2008) Neuroprotection by NGF and BDNF against neurotoxin-exerted apoptotic death in neural stem cells are mediated through Trk receptors, activating PI3-kinase and MAPK pathways. Neurochem Res 34:942-951.

O'Dell SJ, Gross NB, Fridks AN, Casiano BD, Nguyen TB, Marshall JF (2007) Running wheel exercise enhances recovery from nigrostriatal dopamine injury without inducing neuroprotection. Neuroscience 144:1141-1151.

Paxinos G, Watson C (2005) The Rat Brain in Stereotaxic Coordinates. third ed. San Diego: Academic Press.

Petzinger GM, Walsh JP, Akopian G, Hogg E, Abernathy A, Arevalo $P$, Turnquist $P$, Vuckovic M, Fisher BE, Togasaki DM, Jakowec MW (2007) Effects of treadmill exercise on dopaminergic transmission in the 1-methyl-4-phenyl-1,2,3,6-tetrahydropyridine- lesioned mouse model of basal ganglia injury. I Neurosci 27:5291-5300.

Real CC, Ferreira AF, Hernandes MS, Britto LR, Pires RS (2010) Exercise-induced plasticity of AMPA-type glutamate receptor subunits in the rat brain. Brain Res 1363:63-71.

Riddle DR, Katz LC, Lo DC (1997) Focal delivery of neurotrophins into the central nervous system using fluorescent latex microspheres. Biotechniques 23(928-934):936-937.

Salgado-Delgado R, Angeles-Castellanos M, Buijs MR, Escobar C (2008) Intemal desynchronization in a model of night-work by forced activity in rats. Neuroscience 154:922-931.

Sasco AJ, Paffenbarger Jr RS, Gendre I, Wing AL (1992) The role of physical exercise in the occurrence of Parkinson's disease. Arch Neurol 49(4):360-365.

Schober A (2004) Classic toxin-induced animal models of Parkinson's disease: 6-OHDA and MPTP. Cell Tissue Res 318:215-224.

Stahl K, Mylonakou MN, Skare Ø, Amiry-Moghaddam M, Torp R (2011) Cytoprotective effects of growth factors: BDNF more potent than GDNF in an organotypic culture model of Parkinson's disease. Brain Res 1378:105-118.

Steiner B, Winter C, Hosman K, Siebert E, Kempermann G, Petrus DS, Kupsch A (2006) Enriched environment induces œellular plasticity in the adult substantia nigra and improves motor behavior function in the 6-OHDA rat model of Parkinson's disease. Exp Neurol 199(2):291-300.

Sutoo D, Akiyama K (2003) Regulation of brain function by exercise. Neurobiol Dis 13:1-14.

Tajiri N, Yasuhara T, Shingo T, Kondo A, Yuan W, Kadota T, Wang F, Baba T, Tayra JT, Morimoto T, Jing M, Kikuchi Y, Kuramoto S, Agari T, Miyoshi Y, Fujino H, Obata F, Takeda I, Furuta T, Date I (2010) Exercise exerts neuroprotective effects on Parkinson's disease model of rats. Brain Res 1310:200-207.

Tillerson JL, Cohen AD, Caudle WM, Zigmond MJ, Schallert T, Mille GW (2002) Forced nonuse in unilateral parkinsonian rats exacerbates injury. J Neurosci 22:6790-6799.

Toole T, Hirsch MA, Forkink A, Lehman DA, Maitland CG (2000) The effects of a balance and strength training program on equilibrium in Parkinsonism: a preliminary study. NeuroRehabilitation 14:165-174.

Vaynman S, Ying Z, Gomez-Pinilla F (2004) Hippocampal BDNF mediates the efficacy of exercise on synaptic plasticity and cognition. Eur J Neurosci 20:2580-2590.

Zigmond MJ, Cameron JL, Leak RK, Mirnics K, Russell VA, Smeyne RJ, Smith AD (2009) Triggering endogenous neuroprotective processes through exercise in models of dopamine deficiency. Parkinsonism Relat Disord 15(S3):S42-S45.

Wu SY, Wang TF, Yu L, Jen CJ, Chuang JI, Wu FS, Wu CW, Kuo YM (2011) Running exercise protects the substantia nigra dopaminergic neurons against inflammation-induced degeneration via the activation of BDNF signaling pathway. Brain Behav Immun 25:135-146.

Yoon MC, Shin MS, Kim TS, Kim BK, Ko IG, Sung YH, Kim SE, Lee HH, Kim YP, Kim CJ (2007) Treadmill exercise suppresses nigrostriatal dopaminergic neuronal loss in 6-hydroxydopamineinduced Parkinson's rats. Neurosci Lett 423:12-17. 
APÊNDICE B - Tabelas com os dados do capítulo 4

Tabela 1 - Efeitos do exercício em esteira e do bloqueio do receptor de BDNF sobre os testes comportamentais.

\begin{tabular}{|c|c|c|c|c|c|c|c|c|c|}
\hline \multirow{2}{*}{$\begin{array}{c}\text { Teste } \\
\text { comportamental }\end{array}$} & \multirow{2}{*}{$\begin{array}{l}\text { Tempo após } \\
\text { procedimento } \\
\text { cirúrgico }\end{array}$} & \multicolumn{4}{|c|}{ Grupos analisados sem K252a } & \multicolumn{4}{|c|}{ Grupos analisados com K252a } \\
\hline & & CLT & SED & $E X A+E X D$ & EXD & $\begin{array}{r}\mathrm{CLT}+ \\
\mathrm{K} 252 \mathrm{a} \\
\end{array}$ & $\begin{array}{l}\text { SED+ } \\
\text { K252a } \\
\end{array}$ & $\begin{array}{c}\text { EXA+EXD+ } \\
\text { K252a } \\
\end{array}$ & $\begin{array}{l}\mathrm{EXD+} \\
\mathrm{K} 252 \mathrm{a} \\
\end{array}$ \\
\hline \multirow[t]{2}{*}{ Campo aberto } & 7 dias & $135 \pm 6$ & $128 \pm 7$ & $145 \pm 6$ & $149 \pm 3$ & $124 \pm 6$ & $133 \pm 6$ & $134 \pm 6$ & $116 \pm 8^{\#}$ \\
\hline & 28 dias & $90 \pm 8$ & $138 \pm 6^{*}$ & $94 \pm 10$ & $92 \pm 5$ & $100 \pm 6$ & $146 \pm 11^{*}$ & $130 \pm 3^{\#}$ & $121 \pm 8$ \\
\hline Teste rotacional & 29 dias & $7 \pm 1$ & $84 \pm 4^{*}$ & $17 \pm 3$ & $33 \pm 2$ & $8 \pm 2$ & $103 \pm 11^{*}$ & $92 \pm 8^{\star \#}$ & $109 \pm 11^{\text {*\# }}$ \\
\hline
\end{tabular}

Nota: BDNF: fator neurotrófico derivado do encéfalo; K252a: bloqueador do receptor de BDNF (TrkB); CLT: animais sedentários injetados com salina; SED: animais sedentários injetados com 6-OHDA; EXA+EXD: animais treinados em esteira 4 semanas antes e 4 semanas depois da injeção de 6-OHDA; EXD: animais treinados em esteira 4 semanas depois da injeção de 6-OHDA. * $p<0,05$ em relação ao grupo CLT; \# (indica significância entre o grupo que recebeu K252a e seu correspondente que não recebeu a droga

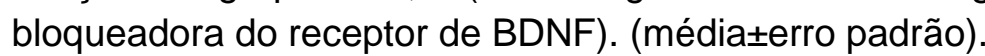


Tabela 2 - Efeitos do exercício em esteira e do bloqueio do receptor de BDNF sobre a expressão de BDNF.

\begin{tabular}{|c|c|c|c|c|c|c|c|c|c|}
\hline \multirow{2}{*}{$\begin{array}{c}\text { Região } \\
\text { encefálica }\end{array}$} & \multirow[t]{2}{*}{ Técnica empregada } & \multicolumn{4}{|c|}{ Grupos analisados sem K252a } & \multicolumn{4}{|c|}{ Grupos analisados com K252a } \\
\hline & & CLT & SED & $E X A+E X D$ & EXD & $\begin{array}{c}\mathrm{CLT}+ \\
\mathrm{K} 252 \mathrm{a} \\
\end{array}$ & $\begin{array}{l}\text { SED+ } \\
\text { K252a }\end{array}$ & $\begin{array}{c}\text { EXA+EXD+ } \\
\text { K252a }\end{array}$ & $\begin{array}{l}\text { EXD+ } \\
\text { K252a } \\
\end{array}$ \\
\hline SNc & Immunoblotting & $1 \pm 0,12$ & $0,43 \pm 0,08^{*}$ & $1,13 \pm 0,05$ & $0,90 \pm 0,09$ & $1 \pm 0,04$ & $0,59 \pm 0,05^{\star}$ & $0,94 \pm 0,02$ & $1,03 \pm 0,06$ \\
\hline Estriado & Immunoblotting & $1 \pm 0,04$ & $1,04 \pm 0,11$ & $1,19 \pm 0,05$ & $1,01 \pm 0,10$ & $1 \pm 0,07$ & $0,88 \pm 0,06$ & $1 \pm 0,09$ & $0,95 \pm 0,09$ \\
\hline
\end{tabular}

Nota: BDNF: fator neurotrófico derivado do encéfalo; K252a: bloqueador do receptor de BDNF (TrkB); CLT: animais sedentários injetados com salina; SED: animais sedentários injetados com 6-OHDA; EXA+EXD: animais treinados em esteira 4 semanas antes e 4 semanas depois da injeção de 6-OHDA; EXD: animais treinados em esteira 4 semanas depois da injeção de 6-OHDA. (médiaterro padrão). 
Tabela 3 - Efeitos do exercício em esteira e do bloqueio do receptor de BDNF sobre a expressão de tirosina-hidroxilase.

\begin{tabular}{|c|c|c|c|c|c|c|c|c|c|}
\hline \multirow{2}{*}{$\begin{array}{l}\text { Região } \\
\text { encefálica }\end{array}$} & \multirow{2}{*}{ Técnica empregada } & \multicolumn{4}{|c|}{ Grupos analisados sem K252a } & \multicolumn{4}{|c|}{ Grupos analisados com K252a } \\
\hline & & $\mathrm{CLT}$ & SED & $E X A+E X D$ & EXD & $\begin{array}{r}\mathrm{CLT}+ \\
\mathrm{K} 252 \mathrm{a} \\
\end{array}$ & $\begin{array}{l}\text { SED+ } \\
\text { K252a } \\
\end{array}$ & $\begin{array}{c}\text { EXA+EXD+ } \\
\mathrm{K} 252 \mathrm{a}\end{array}$ & $\begin{array}{l}\text { EXD+ } \\
\mathrm{K} 252 \mathrm{a} \\
\end{array}$ \\
\hline \multirow[t]{2}{*}{ SNc } & Imuno- histoquímica & $100 \pm 2$ & $56 \pm 4^{*}$ & $77 \pm 2^{*}$ & $81 \pm 4^{*}$ & $100 \pm 1$ & $31 \pm 1^{* \#}$ & $28 \pm 4^{* \#}$ & $38 \pm 4^{\star \#}$ \\
\hline & Immunoblotting & $1 \pm 0,04$ & $0,46 \pm 0,04^{*}$ & $1,13 \pm 0,12$ & $0,87 \pm 0,07$ & $1 \pm 0,03$ & $0,58 \pm 0,10^{*}$ & $0,62 \pm 0,07^{\star \#}$ & $0,55 \pm 0,07^{\star \#}$ \\
\hline \multirow[t]{2}{*}{ Estriado } & Imuno- histoquímica & $1 \pm 0,03$ & $0,45 \pm 0,02^{*}$ & $0,98 \pm 0,02$ & $0,68 \pm 0,03^{*}$ & $1 \pm 0,01$ & $0,56 \pm 0,02^{*}$ & $0,53 \pm 0,04^{\star \#}$ & $0,65 \pm 0,01^{*}$ \\
\hline & Immunoblotting & $1 \pm 0,11$ & $0,24 \pm 0,03^{*}$ & $1,19 \pm 0,10$ & $0,90 \pm 0,05$ & $1 \pm 0,02$ & $0,34 \pm 0,07^{*}$ & $0,63 \pm 0,04^{\star \#}$ & $0,46 \pm 0,06^{\star \#}$ \\
\hline
\end{tabular}

Nota: BDNF: fator neurotrófico derivado do encéfalo; K252a: bloqueador do receptor de BDNF (TrkB); CLT: animais sedentários injetados com salina; SED: animais sedentários injetados com 6-OHDA; EXA+EXD: animais treinados em esteira 4 semanas antes e 4 semanas depois da injeção de 6-OHDA; EXD: animais treinados em esteira 4 semanas depois da injeção de 6-OHDA. *p<0,05 em relação ao grupo CLT; \# (indica significância entre o grupo que recebeu K252a e seu correspondente que não recebeu a droga bloqueadora do receptor de BDNF). (médiaterro padrão). 


\section{APÊNDICE C - Tabelas com os dados do capítulo 5}

Tabela 1 - Efeitos do exercício em esteira antes da indução do modelo da DP e do bloqueio do receptor de BDNF sobre a expressão de tirosina-hidroxilase e do teste rotacional, no $30^{\circ}$ dia após a indução do modelo da DP.

\begin{tabular}{|c|c|c|c|c|c|c|c|c|c|}
\hline \multirow{2}{*}{$\begin{array}{c}\text { Região } \\
\text { encefálica }\end{array}$} & \multirow[t]{2}{*}{ Técnica empregada } & \multicolumn{4}{|c|}{ Grupos analisados sem K252a } & \multicolumn{4}{|c|}{ Grupos analisados com K252a } \\
\hline & & SED & EX & SED+DP & $\mathrm{EX}+\mathrm{DP}$ & $\begin{array}{l}\text { SED+ } \\
\text { K252a } \\
\end{array}$ & $\begin{array}{c}\text { EX+ } \\
\text { K252a }\end{array}$ & $\begin{array}{c}\text { SED+DP+ } \\
\text { K252a }\end{array}$ & $\begin{array}{c}\mathrm{EX}+\mathrm{DP}+ \\
\mathrm{K} 252 \mathrm{a}\end{array}$ \\
\hline \multirow[t]{2}{*}{ SNc } & Imuno- histoquímica & $100 \pm 2$ & $101 \pm 2$ & $28 \pm 3^{*}$ & $53 \pm 2^{*}$ & $100 \pm 0,5$ & $100 \pm 7$ & $31 \pm 1^{*}$ & $28 \pm 5^{\star \#}$ \\
\hline & Immunoblotting & $1 \pm 0,04$ & $0,93 \pm 0,02$ & $0,48 \pm 0,04^{*}$ & $1,05 \pm 0,03$ & $1 \pm 0,07$ & $1,08 \pm 0,06$ & $0,51 \pm 0,07^{*}$ & $0,43 \pm 0,08^{\star \#}$ \\
\hline \multirow[t]{3}{*}{ Estriado } & Imuno- histoquímica & $1 \pm 0,02$ & $1,01 \pm 0,02$ & $0,50 \pm 0,04^{*}$ & $0,92 \pm 0,01$ & $1 \pm 0,01$ & $1 \pm 0,01$ & $0,56 \pm 0,02^{*}$ & $0,75 \pm 0,04^{* \#}$ \\
\hline & Immunoblotting & $1 \pm 0,04$ & $0,95 \pm 0,01$ & $0,49 \pm 0,02^{*}$ & $0,91 \pm 0,01$ & $1 \pm 0,02$ & $1,02 \pm 0,06$ & $0,34 \pm 0,07^{*}$ & $0,32 \pm 0,04^{\star \#}$ \\
\hline & Teste Rotacional & $7 \pm 2$ & $5 \pm 1$ & $105 \pm 15^{\star}$ & $48 \pm 11^{*}$ & $8 \pm 2$ & $14 \pm 4$ & $103 \pm 15^{\star}$ & $65 \pm 10^{*}$ \\
\hline
\end{tabular}

Nota: BDNF: fator neurotrófico derivado do encéfalo; K252a: bloqueador do receptor de BDNF (TrkB); SED: animais sedentários injetados com salina; EX: animais treinados em esteira 4 semanas antes de serem injetados com salina; SED+DP: animais sedentários injetados com 6-OHDA; EX+DP: animais treinados em esteira 4 semanas antes da injeção de 6-OHDA; * $p<0,05$ em relação ao grupo SED e EX; " (indica significância entre o grupo que recebeu K252a e seu correspondente que não recebeu a droga bloqueadora do receptor de BDNF). (médiaterro padrão). 
Tabela 2 - Efeitos do exercício em esteira antes da indução do modelo da DP a expressão de BDNF e DHE, no 7ํ dia após a indução do modelo da DP.

\begin{tabular}{|c|c|c|c|c|c|c|c|c|}
\hline \multirow{2}{*}{$\begin{array}{c}\text { Região } \\
\text { Encefálica }\end{array}$} & \multicolumn{4}{|c|}{ ELISA para BDNF } & \multicolumn{4}{|c|}{ DHE } \\
\hline & SED & EX & SED+DP & $\mathrm{EX}+\mathrm{DP}$ & SED & EX & SED+DP & $E X+D P$ \\
\hline SNc & $11,37 \pm 0,06$ & $11,94 \pm 0,36$ & $13,54 \pm 0,22^{*}$ & $11,83 \pm 0,39$ & $100 \pm 2$ & $108 \pm 7$ & $141 \pm 11^{* *}$ & $97 \pm 1$ \\
\hline Estriado & $26,72 \pm 5,09$ & $22,13 \pm 5,63$ & $24,39 \pm 0,93$ & $30,18 \pm 4,10$ & $100 \pm 3$ & $92 \pm 7$ & $118 \pm 4$ & $86 \pm 8$ \\
\hline
\end{tabular}

Nota: BDNF: fator neurotrófico derivado do encéfalo; DHE: dihidroetidina (marcador de espécie reativa de oxigênio); SED: animais sedentários injetados com salina; EX: animais treinados em esteira 4 semanas antes de serem injetados com salina; SED+DP: animais sedentários injetados com 6-OHDA; EX+DP: animais treinados em esteira 4 semanas antes da injeção de 6-OHDA; *p<0,05 em relação ao

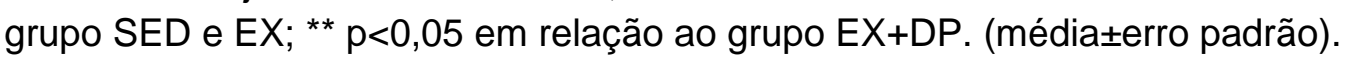


Tabela 3 - Efeitos do exercício em esteira antes da indução do modelo da DP sobre a expressão de tirosina-hidroxilase e marcadores de neuroinflamação, no $7^{\circ}$ dia após a indução do modelo da DP.

\begin{tabular}{|c|c|c|c|c|c|c|c|c|c|c|}
\hline \multirow{2}{*}{$\begin{array}{l}\text { Região } \\
\text { Encefálica }\end{array}$} & \multirow[t]{2}{*}{ Proteína } & \multicolumn{4}{|c|}{ Imuno-histoquímica } & \multirow[t]{2}{*}{ Proteína } & \multicolumn{4}{|c|}{ Immunoblotting } \\
\hline & & SED & EX & SED+DP & $\mathrm{EX}+\mathrm{DP}$ & & SED & EX & SED+DP & $\mathrm{EX}+\mathrm{DP}$ \\
\hline \multirow[t]{3}{*}{ SNc } & TH & $100 \pm 6$ & $98 \pm 5$ & $61 \pm 4^{*}$ & $100 \pm 7$ & $\mathrm{TH}$ & $1 \pm 0,06$ & $0,92 \pm 0,05$ & $0,44 \pm 0,09^{*}$ & $0,66 \pm 0,07^{*}$ \\
\hline & GFAP & $1 \pm 0,06$ & $1,23 \pm 0,10$ & $2,28 \pm 0,06^{*}$ & $1,50 \pm 0,07$ & GFAP & $1 \pm 0,18$ & $1,07 \pm 0,12$ & $2,29 \pm 0,07^{*}$ & $1,15 \pm 0,16$ \\
\hline & OX42 & $1 \pm 0,02$ & $1 \pm 0,08$ & $1,02 \pm 0,03$ & $1,10 \pm 0,04$ & iNOS & $1 \pm 0,08$ & $1,33 \pm 0,08$ & $3 \pm 0,04^{*}$ & $1,73 \pm 0,10$ \\
\hline \multirow[t]{3}{*}{ Estriado } & TH & $1 \pm 0,03$ & $0,95 \pm 0,07$ & $0,75 \pm 0,03^{*}$ & $1 \pm 0,01$ & TH & $1 \pm 0,03$ & $0,90 \pm 0,09$ & $0,18 \pm 0,03^{*}$ & $0,47 \pm 0,06^{*}$ \\
\hline & GFAP & $1 \pm 0,05$ & $0,83 \pm 0,12$ & $1,73 \pm 0,08^{*}$ & $0,88 \pm 0,12$ & GFAP & $1 \pm 0,13$ & $1,08 \pm 0,10$ & $2,34 \pm 0,01$ & $0,95 \pm 0,12$ \\
\hline & OX42 & $1 \pm 0,09$ & $1,06 \pm 0,03$ & $1,35 \pm 0,04^{*}$ & $1,12 \pm 0,08$ & iNOS & $1 \pm 0,12$ & $1,19 \pm 0,22$ & $1,99 \pm 0,20^{*}$ & $1,05 \pm 0,03$ \\
\hline
\end{tabular}

Nota: BDNF: fator neurotrófico derivado do encéfalo; K252a: bloqueador do receptor de BDNF (TrkB); SED: animais sedentários injetados com salina; EX: animais treinados em esteira 4 semanas antes de serem injetados com salina; SED+DP: animais sedentários injetados com 6OHDA; EX+DP: animais treinados em esteira 4 semanas antes da injeção de 6-OHDA; TH: tirosina-hidroxilase (enzima limitante da síntese de DA); OX42: marcador de microglia; GFAP: proteína acídica fibrilar glial (marcador de proliferação astrocitária); iNOS: enzima óxido

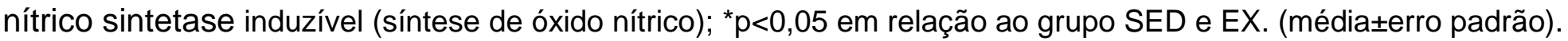

